
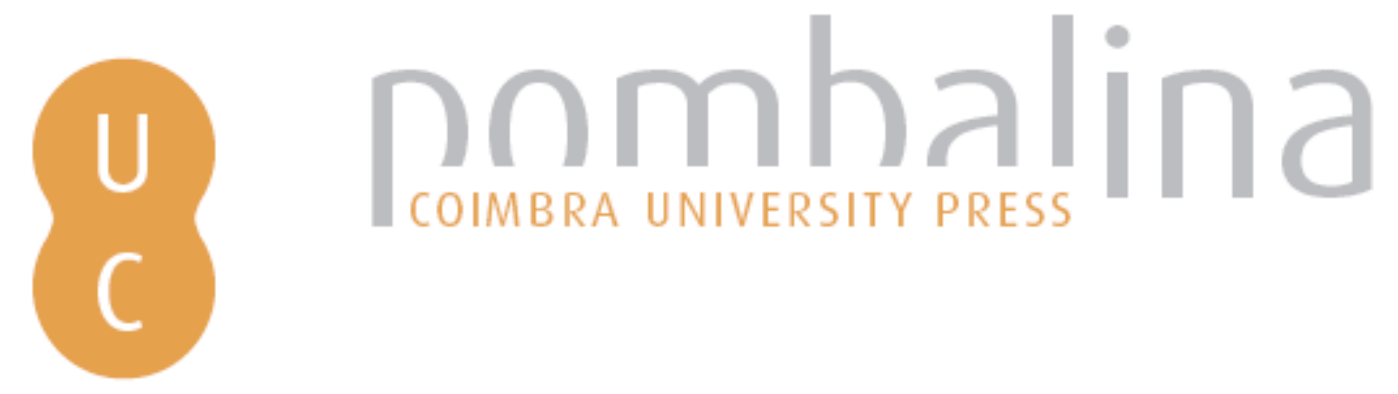

\title{
Representações de teatro clássico no Portugal Contemporâneo: vol. III
}

\author{
Autor(es): $\quad$ Silva, Maria de Fátima Sousa e, ed. lit.
}

Publicado por: Faculdade de Letras da Universidade de Coimbra

URL

persistente: URI:http://hdl.handle.net/10316.2/2328

DOI: $\quad$ DOI:http://dx.doi.org/10.14195/978-989-26-1003-0

Accessed : $\quad$ 26-Apr-2023 05:01:09

A navegação consulta e descarregamento dos títulos inseridos nas Bibliotecas Digitais UC Digitalis, UC Pombalina e UC Impactum, pressupõem a aceitação plena e sem reservas dos Termos e Condições de Uso destas Bibliotecas Digitais, disponíveis em https://digitalis.uc.pt/pt-pt/termos.

Conforme exposto nos referidos Termos e Condições de Uso, o descarregamento de títulos de acesso restrito requer uma licença válida de autorização devendo o utilizador aceder ao(s) documento(s) a partir de um endereço de IP da instituição detentora da supramencionada licença.

Ao utilizador é apenas permitido o descarregamento para uso pessoal, pelo que o emprego do(s) título(s) descarregado(s) para outro fim, designadamente comercial, carece de autorização do respetivo autor ou editor da obra.

Na medida em que todas as obras da UC Digitalis se encontram protegidas pelo Código do Direito de Autor e Direitos Conexos e demais legislação aplicável, toda a cópia, parcial ou total, deste documento, nos casos em que é legalmente admitida, deverá conter ou fazer-se acompanhar por este aviso.

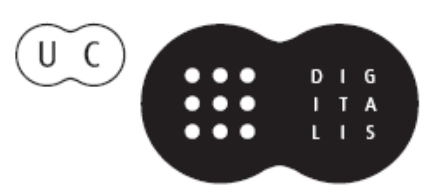




\section{REPRESENTAÇÕES DE TEATRO CLÁSSICO no PORTUGAL CONTEMPORÂNEO} vol. III

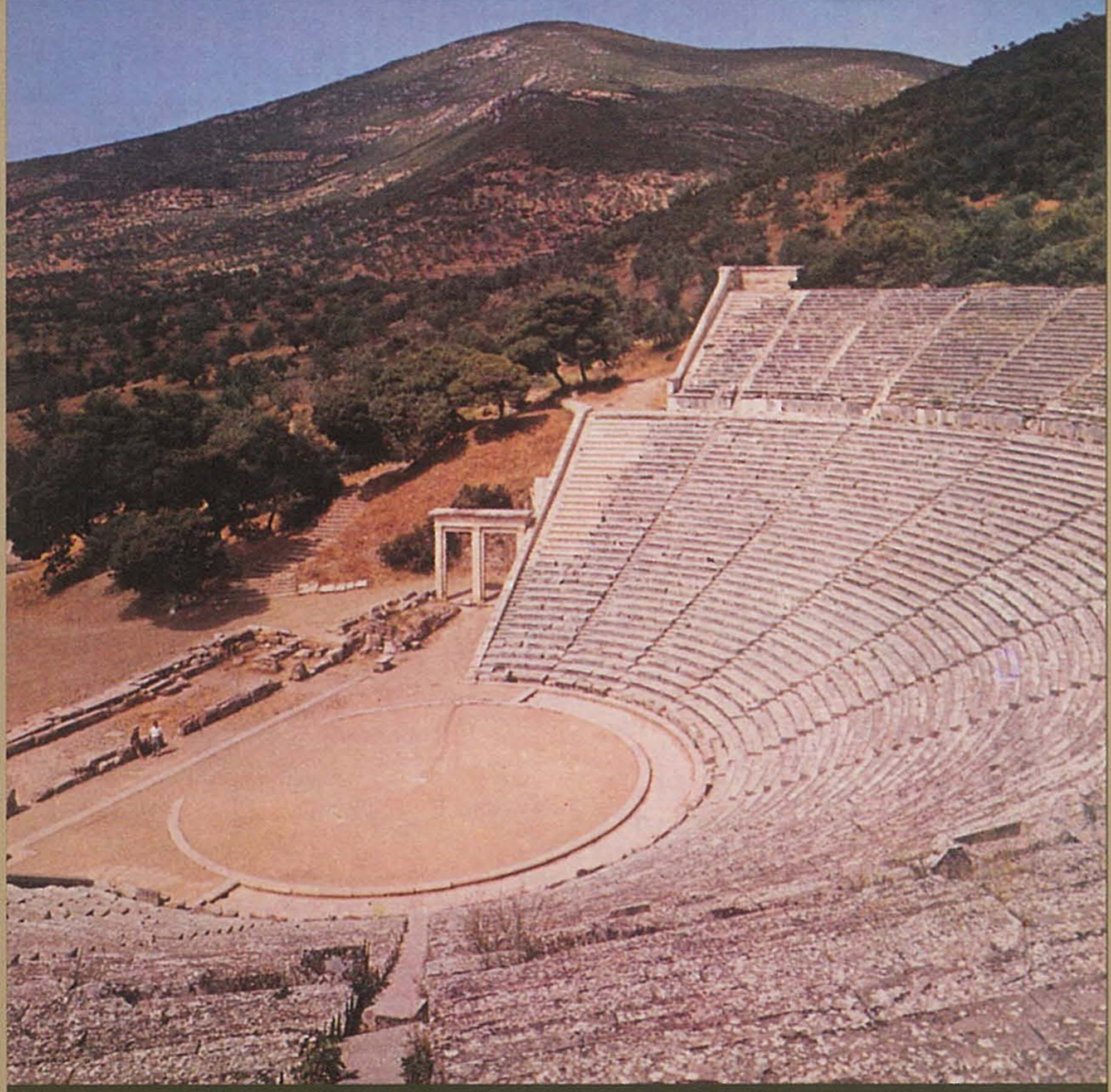

Faculdade de Letras da Universidade de Coimbra 
(Página deixada propositadamente em branco) 


\section{REPRESENTAÇÕES DE TEATRO CLÁSSICO NO PORTUGAL CONTEMPORÂNEO}




\section{Biblioteca Nacional - Catalogação na Publicação}

Representações de Teatro Clássico no Portugal Contemporâneo, Vol. III, Coimbra, 2004

Maria de Fátima Sousa e Silva (Estudos, 55)

ISBN: 972-9038-77-5

ISBN DigiTAL: 978-989-26-1003-0

DOI: http://dx.doi.org/10.14195/978-989-26-1003-0

I- Silva, Maria de Fátima Sousa e, 1950

II- Grupo de Investigação do Centro de Estudos Clássicos e Humanísticos da F.L.U.C.

$$
\begin{gathered}
\text { CDU } \\
\text { 792(-1.38)(469)“19” } \\
821.1402-2
\end{gathered}
$$

Titulo: Representações de Teatro Clássico no Portugal Contemporâneo, Vol. III Autores: Maria de Fátima Sousa e Silva (coord.), Grupo de Investigação do Centro de Estudos Clássicos e Humanísticos da F.L.U.C.

Coordenação Editorial: Gabinete de Publicações da F.L.U.C.

Capa: Victor Torres

Depósito Legal n. ${ }^{0}: 216949 / 04$

Impressão: Secção de Textos da F.L.U.C.

Tiragem: 500

(C) Faculdade de Letras da Universidade de Coimbra

Outubro de 2004 


\title{
REPRESENTAÇÕES DE TEATRO CLÁSSICO NO PORTUGAL CONTEMPORÂNEO
}

\author{
VOL. III
}

Coordenação

Maria de Fátima Sousa e Silva

*

Faculdade de Letras da Universidade de Coimbra 
(Página deixada propositadamente em branco) 


\section{COORDENAÇÃO}

Maria de Fátima Sousa e Silva

\section{COLABORADORES}

Ana Paula Quintela

Carlos A. Martins de Jesus

Carlos Manuel Ferreira Morais

Carmen Isabel Leal Soares

Cidália Ventura

Cláudia Raquel Cravo da Silva

Delfim Ferreira Leão

Jorge Pereira Nunes do Deserto

José Luís Brandão

José Manuel Ventura

José Ribeiro Ferreira

Luísa de Nazaré Ferreira

Maria do Céu Zambujo Fialho

Maria Helena da Rocha Pereira

Mário Paulo Martins

Marta Isabel de Oliveira Várzeas

Nuno Simões Rodrigues

Paula Barata Dias

Paulo Sérgio Ferreira

Susana Hora Marques 
(Página deixada propositadamente em branco) 


\section{ÍNDICE}

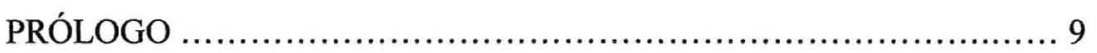

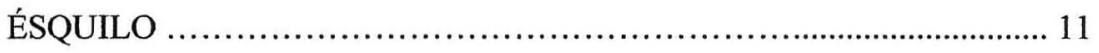

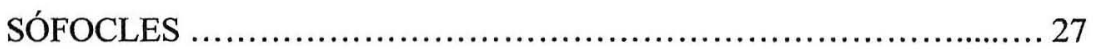

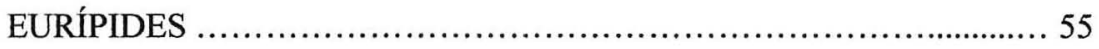

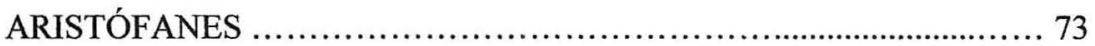

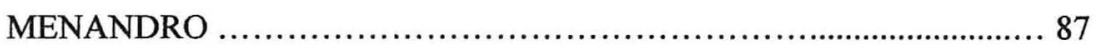

ADAPTAÇÕES DE TEMAS GREGOS .................................. 91

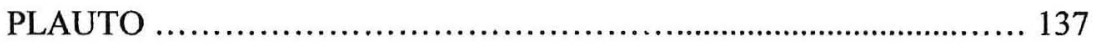

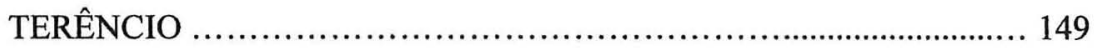

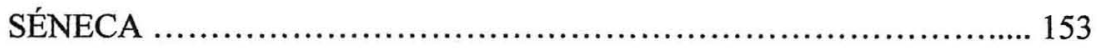

ADAPTAÇÕES DE TEMAS LATINOS .................................. 159 
(Página deixada propositadamente em branco) 


\section{PRÓLOGO}

Passada cerca de uma década sobre o arranque de um projecto que visava a recolha sistemática de representações de teatro clássico no Portugal contemporâneo, é chegada a hora da publicação de um III volume de resultados da pesquisa entretanto realizada. Nos dois volumes anteriores (publicados respectivamente em 1998 e 2001) procurou cobrir-se o material referente a todo o séc. XX, que o III que agora se apresenta vem complementar com a informação respeitante aos primeiros anos do séc. XXI. Naturalmente que os espectáculos entretanto identificados que estavam em falta nos dois primeiros volumes são aqui integrados, mesmo se sob pena de algum anacronismo. O espírito que presidiu ao prosseguimento da tarefa manteve-se o mesmo. Porque nos parece importante registar os esforços que, a todos os níveis, se vai fazendo no sentido de privilegiar os temas clássicos sob forma de espectáculo, ao teatro, nosso objectivo fundamental, acrescentou-se a leitura dramatizada, o cinema, a música e a dança. Por outro lado, o levantamento feito contempla grupos profissionais e amadores, nacionais e estrangeiros, desde que a obra produzida tenha sido apresentada no nosso país. Esta abertura colocada nos critérios de recolha vai, por um lado, ao encontro da importãncia que em Portugal continua a ter a iniciativa amadora, universitária ou escolar nesta matéria; independentemente do nível de criação dos espectáculos promovidos, a verdade é que, no seu conjunto, eles espelham a forma como o público português, no seu plano mais geral, reage e acolhe este padrão restrito de expressão cultural. É gratificante verificar, ao fim de anos de trabalho, que o produto disponibilizado, cuja ambição não vai muito além do simples registo, tem incentivado a investigação a um nível mais aprofundado que se exprimiu já em diversas teses de mestrado.

Importa registar, como sempre, o esforço realizado por todos os elementos que integram este grupo de trabalho. Da mobilização de cada um na busca de materiais e na promoção de contactos depende o resultado final da pesquisa colectiva. Mas impõe-se também agradecer a todos - grupos de teatro, actores, professores ou pessoas individuais - que generosamente nos proporcionaram informações e materiais sem os quais o nosso inventário ficaria muito mutilado. A todos os que, com generosidade, colaboraram connosco prestando-nos informações ou qualquer tipo de testemunho deixamos aqui expresso o nosso mais caloroso agradecimento.

Uma palavra de gratidão é devida em particular, de entre os elementos da equipa de colaboradores, ao Doutor José Luís Brandão, pela intervenção que teve, para além da recolha de elementos e da redacção, na 
execução gráfica do volume, bem como ao nosso estudante Carlos Martins de Jesus que pôs a sua competência de jovem ao serviço da resolução das questões informáticas que a execução do volume levantava.

É inevitável que um trabalho desta natureza não esteja nunca completo; esperamos mesmo daqueles que se sintam penalizados pela ausência ou imprecisão de uma referência que nos ajudem a suprir as nossas lacunas. Assim contribuimos para preservar a memória de uma actividade que representa, no nosso país, uma forma de expressão do interesse pelos Clássicos, ao mesmo tempo que, no plano internacional, porque nos integramos numa rede de equipas que multiplicam a mesma tarefa por muitos países europeus, pomos Portugal no mapa das sociedades modernas onde o gosto pela cultura greco-latina continua a ser uma inegável realidade.

Maria de Fátima Silva 


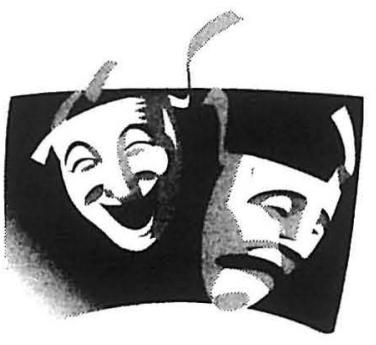

ÉSQUILO 
(Página deixada propositadamente em branco) 


\section{ORESTEIA}

\section{Ésquilo, Oresteia}

Produção: Grupo Retaguarda - Teatro Fechado

Encenação: Nuno Cardoso

Dramaturgia: Regina Guimarães

Iniciativa: Porto Capital da Cultura 2001

Apresentação: Cadeia de Paços de Ferreira

Data: 15-21.2. 2001.

O grupo de teatro do Instituto Prisional de Paços de Ferreira levou à cena a Oresteia de Ésquilo entre os dias 15 e 21 de Fevereiro de 2001,

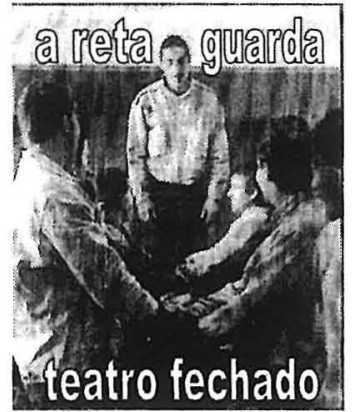

na cadeia de Paços de Ferreira. As representações foram divididas entre sessões para a população reclusa (estão previstos espectáculos noutras instituições prisionais do país) e para o público em geral, em particular para os familiares visitantes do local. A encenação esteve a cargo de Nuno Cardoso, Director do Auditório Nacional de Carlos Alberto (ANCA), que ensaiou com cerca de uma vintena de reclusos um texto da dramaturga e professora universitária Regina Guimarães. Foi ela quem procedeu à adaptação do original do tragediógrafo grego às condições de recepção de um público moderno e particular. Podemos referir algumas das transformações: Regina Guimarães compôs um guião que anula a autonomia das peças esquilianas, e tomou a opção de fazer começar a encenação com uma narrativa inicial introdutória, da qual se cai, abruptamente, na cena clímax da obra prima esquiliana: o julgamento do matricídio de Orestes pelo tribunal do Areópago, em Atenas. As restantes cenas surgem sobretudo a partir de analepses, ajudadas pelos recursos do teatro contemporâneo. $O$ texto também é adaptado a um ritmo mais próximo do ouvido lusitano: o verso rimado em redondilha maior. No entanto, o conteúdo é preservado de forma sublime: estão em causa as grandes questões e os conflitos que animam o drama esquiliano: agir ou reagir, culpa ou necessidade, razão e justiça, vingança ou castigo, morte e remorso e, por fim, a lei dos homens e seus limites ...

Este projecto foi integrado no programa de Artes do Espectáculo, sob o pelouro de Isabel Alves da Costa, inserido na comemoração do Porto Capital da Cultura 2001: a iniciativa Teatros do Outro tem congregado os esforços da dramaturga Regina Guimarães que, como o nome do projecto indica, tem levado a arte teatral aos palcos menos prováveis, ao protagonismo dos que se sabiam actores apenas dos dramas da sobrevivência diária: como referimos, o Instituto Prisional de Paços de Ferreira, mas também os menores 
do Colégio de Santo António, os moradores de um bairro social do Porto, amadores anónimos da grande malha urbana do Porto, têm vindo a protagonizar estas experiências cujo objectivo é fazer o teatro sair das grandes salas e do profissionalismo dos seus agentes, para participar de uma estratégia de inclusão ao serviço de um 'direito de cidadania'.

Esta intenção de procurar 'outros palcos, outros públicos' restitui o teatro ao seu valor primeiro, o de envolver os cidadãos numa reflexão comunitária para lá dos domínios estéticos, ou dos artísticos a que a sensibilidade moderna confinou essa forma superior de arte ... só podemos comentar que de uma forma autêntica a vocação teatral retomou, com esta experiência e outras que sobrevenham deste interessante projecto Teatros do Outro, a memória do seu ancestral passado, no tempo em que o teatro servia de veículo de expressão, de reflexão e de educação de uma cidade ...

Quanto à experiência protagonizada pelo Grupo Retaguarda, destaque-se o profissionalismo com que a experiência foi conduzida pelo encenador e pelos actores: seria fácil, pelos contactos óbvios (mas demasiado fáceis) entre o conteúdo da peça e a experiência de vida dos reclusos, produzir um espectáculo contaminado e distante do que é a obra de Ésquilo. Tal não aconteceu, pois os actores assumiram do início um distanciamento entre as suas experiências pessoais e a ficção esquiliana. Pelos testemunhos recolhidos, 'este incrivel trabalho de teatro' teve o mérito de criar um espaço de liberdade a pessoas dela privadas. Sem apelar ao paternalismo nem à vitimização dos seus actuantes, encenou-se de forma criativa, envolvente e actual a problemática intemporal da trilogia. Foi, em suma, a Oresteia que subiu ao palco.

Elenco: Actores - Franklin Novo, António Maio, Manuel Almeida, Carlos Glória, Paulo Segadães, Rui Sousa, Fernando Lavado, Fernando Couto, Horácio Santos, António Joaquim Fernandes, Diamantino Oliveira, Carlos Manuel Silva, Carlos Augusto, Fernando Lobo, Francisco Sousa, Fernando Jorge Soares, Filipe Gonçalves; Equipa de Apoio - Saguenail, Rui Coelho, Paulo Américo; Cenografia - Eric da Costa \& Teatro Fechado; Som e Música - Albrecht Loops \& Teatro Fechado; Equipa Artística - Mário João Mendes (cenário), Manuel Queiroz (som), Carlos Alberto Gomes (guitarra).

Paula Barata Dias

Ésquilo, Coéforas

Produção: Grupo Balbo do IES de Santo Domingo de Puerto de Santa Maria (Cádis)

Iniciativa: III Festival Escolar de Teatro de Tema Clássico 
$1^{a}$ Apresentação: Conímbriga

Data: 27. 4. 2001

Outras: Coimbra (Pátio da Universidade), 6. 7. 2001; Viseu (Teatro Viriato), 7. 7. 2001; Mosteiro de Tibães, 7.7. 2002; Coimbra (Pátio da Universidade), 8. 7. 2002; Castelo de Montemor-o-Velho, 29. 4. 2003.

Integrada no III Festival Escolar de Teatro de Tema Clássico, foi apresentada no dia 27 de Abril de 2001, em Conímbriga, a tragédia Coéforas de Ésquilo pelo Grupo Balbo. Os jovens actores estudantes de Cádis pretendiam uma representação fiel do texto de Ésquilo e do ambiente da sua tragédia, para o que, segundo afirmaram os próprios, levaram a cabo um trabalho de investigação do drama esquiliano, nas suas vertentes filosófica, histórica e literária.

Elenco: Actores - Javier Ortega (Orestes), Lisi Mena Linder (Electra), Eva Rodríguez Cruz (Clitemnestra, Ama), Marcos Collado Martín (Egisto), Juán Lorca (Agamémnon), Nerea Miranda Ramirez (Corifeu); Coro - Fátima Jiménez Enrique, Esther Pumar Reyes, Luisa Pinto Tey, Patricia Buller Viqueira, Maria Isabel Crespo Garcia, Patricia López, Marga Dominguez Sánchez; Jorge Romo Serrano, Jesús María Gutiérrez Torres, Adrian Varo García (Soldados); Adereços - Trabalho de grupo; Coreografia - Trabalho de grupo; Vestuário - Trabalho de grupo; Director Técnico - Ioaco Ariona.

Marta Várzeas

\section{Ésquilo, Oresteia}

Leitura encenada: A4 (Maria João Seixas, Helena Vasconcelos, Maria da Conceição Caleiro, Paula Moura Pinheiro)

Encenação: Jorge da Silva Melo, Álvaro García de Zuñiga

Apresentação: Fundação Gulbenkian (escadarias do hall)

Data: 17. 5. 2003.

Com o apoio da Fundação Gulbenkian e por iniciativa das A4, promoveu-se um dia da tragédia grega, onde se fez uma leitura encenada da Oresteia com apresentação de José Pedro Serra. A leitura incidiu sobre passos seleccionados da trilogia e foi feita a várias vozes por um grupo de actores dos Artistas Unidos. A motivação pretendeu revestir a forma de um ensaio, onde o encenador Jorge da Silva Melo dá instruções aos actores sobre o sentido profundo das palavras que pronunciam. Trata-se, portanto, não de apresentar obra acabada, mas de montar diante do público as traves mestras de um espectáculo. Em função da coincidência entre esta realização cultural e o controverso ataque aliado ao Iraque, foi inevitável a remissão de um texto de guerra para a campanha do momento. 
Elenco: Actores - Luís Madureira (Agamémnon), Teresa Sobral (Clitemnestra), Isabel Muñoz Cardoso (Cassandra), Pedro Carraca (Orestes).

M. F. S. S.

\author{
Eugene O'Neill, Electra e os Fantasmas \\ Produção: Club PT \\ Iniciativa: $4^{\circ}$ Festival de Teatro Amador $\left(4^{\circ}\right.$ Fes.TA) \\ $1^{\text {a }}$ Apresentação: Lisboa, Auditório do Clube PT \\ Data: 30-31. 5. 2003.
}

M.F.S. S.

\title{
Eugene O'Neil, Mourning becomes Electra
}

Produção: Dudley Nichols, RKO

Data da Produção: 1947

Direcção Cinematográfica: Dudley Nichols

$1^{\text {a }}$ Apresentação: 29. 9. 1949, no cinema Politeama

Outras: Iniciativa do Colóquio 2500 Anos, Sófocles/Cinemateca PortuguesaMuseu do Cinema, 9. 12. 2003.

Esta adaptação cinematográfica assenta na peça homónima de O'Neil, cujo argumento retoma o antigo mito grego da casa dos Atridas. Basta enunciar os nomes de algumas da personagens para nos apercebermos da relação com a antiga narrativa: Ezra Mennon-Agamémnon; Orin-Orestes; Christine-Clitemnestra. O ambiente clássico prevalece na contextualização de toda a peça, como é evidente pela mansão colonial americana que ostenta colunas clássicas. A guerra de Tróia, na qual Agamémnon buscou a sua perdição trágica, é aqui substituída pela Guerra da Secessão. Há, todavia, na concepção de O'Neil, alterações significativas: o amor e consequente ciúme que Lavínia-Electra sente por Adam-Egisto, amante da sua mãe; a forma suave que Christine-Clitemnestra encontra para eliminar Ezra-Agamémnon, envenenando-o em vez de o apunhalar, como na tragédia de Ésquilo; o suicídio de Christine-Clitemnestra, que contrasta com o momento fulcral das Coéforas de Ésquilo ou da Electra de Eurípides.

Como nota Frederico Lourenço, no texto distribuído pela Cinemateca aquando desta apresentação do filme, esta revisão do mito deve muito à contribuição que Freud e Hofmannstal deram nos últimos dois séculos, pois nestas caracterizações de Electra-Lavínia e de Orestes-Orin reconhece-se bastante bem os chamados «complexos de Édipo» e de «Electra», de que as figuras originais não padeciam. Aliás, como nota o 
mesmo Autor, o Orestes de O'Neil e desta adaptação acaba por ser mais Édipo em relação «a Clitemnestra-Christine do que alguma vez o Édipo de Sófocles foi relativamente à sua Jocasta».

Sublime é a interpretação de Rosalind Russell, nomeadamente na cena final, quando ordena que fechem todas as portas e janelas da mansão, onde opta por se enterrar em vida, como que entrando num mundo de trevas $\mathrm{e}$ confirmando assim o luto que lhe fica tão bem. Com essa atitude, consuma-se a tragicidade desta Electra do século XX, retomando ideias fundamentais que a mesma personagem havia já colhido nos trágicos antigos.

Esta produção, já raramente exibida, como se comprova pela cópia apresentada na Cinemateca Portuguesa, pôde ser revista em Lisboa no âmbito das comemorações dos 2500 anos do nascimento de Sófocles, organizadas pelos Centros de Estudos Clássicos das Faculdades de Letras das Universidades de Coimbra e Lisboa, a que a Cinemateca Portuguesa-Museu de Cinema se associou.

Elenco: Actores - Rosalind Russell (Lavinia Mannon), Michael Redgrave (Orin Mannon), Raymond Massey (Ezra Mannon), Katina Paxinou (Christine Mannon), Leo Genn (Adam Brant), Kirk Douglas (Peter Niles), Nancy Coleman (Hazel Niles), Henry Hull (Seth Beckwith), Sara Allgood, Thurston Hall, Elizabeth Risdon, Walter Baldwin; Argumento - Dudley Nichols, baseado na peça de Eugene O'Neil; Fotografia - George Barnes; Montagem - Roland Gross e Chandler House; Direç̧ão Artística - Albert d'Agostino; Música - Richard Hageman; Direcção Musical - C. Bakaleinikoff.

Nuno S. Rodrigues

Pier Paolo Pasolini, Appunti per un'Orestiade Africana / 1970

Realização: Pier Paolo Pasolini

Iniciativa: Cinemateca Portuguesa / Museu do Cinema - Comemoração dos 2500 Anos do Nascimento de Sófocles

$1^{a}$ Apresentação (em Portugal): Fundação Calouste Gulbenkian, 'Ciclo Pier Paolo Pasolini'

Data: 24. 10. 1985

Outras: Lisboa (Cinemateca Portuguesa), 3. 12. 2003.

Por altura da comemoração dos 2500 Anos do Nascimento de Sófocles, a Cinemateca Portuguesa organizou, em colaboração com o Departamento de Estudos Clássicos e com o Centro de Estudos Clássicos da Faculdade de Letras de Lisboa, um ciclo de cinema inspirado em temas sofoclianos. Foi neste contexto possível rever os Appunti per un'Orestiade 
Africana de Pier Paolo Pasolini. O enquadramento privilegiado pelo filme é o da África da descolonização, encarada como cenário da trilogia de Ésquilo dentro do qual se desenrola o nascimento de uma democracia. A estratégia aponta para algo como cinema dentro do cinema, porque se simula a possibilidade de fazer um filme discutida, numa universidade italiana, entre Pasolini e um grupo de estudantes africanos. Numa primeira parte, são mostradas paisagens e rostos de gentes africanas, enquanto em voz off se vai descrevendo a intriga da Oresteia. Uma imagem particularmente simbólica é a que acompanha a menção das Erínias, um conjunto de árvores sacudidas pelo vento, como Fúrias agitadas. É sobre esta imagem que Pasolini insiste no momento de reflexão que sucede à primeira parte: como transformar estas Erínias do universo de África em tranquilas Euménides?

Uma segunda parte valoriza imagens de arquivo colhidas a propósito do tremendo conflito civil do Biafra, uma espécie de nova guerra de Tróia. Este motivo fundamental é sublinhado por uma outra estratégia, musical desta vez: a fala de Cassandra acompanhada pelo conjunto musical de Gato Barbieri e entoada por uma cantora negra. De novo Pasolini e os seus jovens interlocutores introduzem uma reflexão, desta vez sobre o que é, para um jovem africano em tempo de profunda crise na sua terra e casa, vestir a pele do vingador, Orestes.

É exactamente Orestes o centro inspirador de uma terceira parte, onde um negro, depois de rituais junto ao túmulo de seu pai, vive diversos errores até à redenção, no templo da sabedoria, a Universidade de Dar-es Salam.

Elenco: Fotografia - Giorgio Pelloni; Música - Gato Barbieri; Produção - Gian Vittorio Baldi.

M. F. S. S.

Jean-Paul Sartre, Ésquilo, Sófocles, As Moscas

Produção: Sin-Cera

Encenação: Pedro Wilson

$1^{\mathrm{a}}$ Apresentação: Santiago Alquimista

Data: 5. 5. 2004

Outras: FATAL 2004- $5^{\circ}$ Festival Anual de

Teatro Académico de Lisboa, 23. 5. 2004.

As Moscas assenta na Oresteia como texto base, sendo já referenciada como um texto clássico do século XX. Também

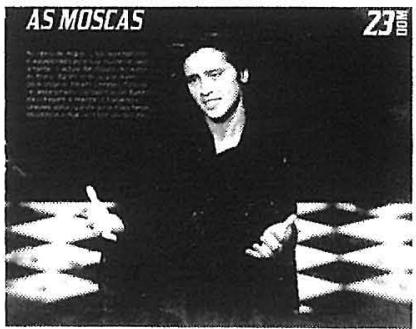
neste texto Agamémnon é assassinado em Argos por Clitemnestra e Egisto. Este, ao subir ao trono, ordena a execução de Orestes, o legítimo sucessor do 
trono, mas os seus enviados falham em cumprir esse desejo e Orestes regressa quinze anos depois, decidido a vingar a morte de Agamémnon.

Como tantas outras releituras dos mitos clássicos, esta revisitação do tema de Orestes e Electra por parte de Sartre encontra eco numa realidade do tempo do Autor, mais em concreto na ocupação nazi de França, ao mesmo tempo que transmite a mensagem filosófica do seu Autor: «o homem é absolutamente livre, mas absolutamente irresponsável». Esta encenação, apresentada por um grupo da Universidade do Algarve, teve a particularidade de ter sido feita por um encenador que esteve muito ao Cénico de Direito, da Faculdade de Direito da Universidade de Lisboa, desde 1993.

Elenco: Actores - Alice Martins, Dário Cruz, Fúlvia Almeida, Hugo Sancho, Inês Carvalho, Joana Costa, Lígia Martins, Márcio Guerra, Marco Ferraz, Nuno Murta, Ricardo Mendonça, Rui Cabrita, Sónia Esteves, Susana Nunes, Vera Rodrigues; Adaptação Dramatúrgica - Pedro Wilson; Cenário - Tó Quintas; Figurinos - Pedro Wilson, Sin-Cera; Sonoplastia - Pedro Wilson, Susana Nunes; Desenho de Luz - Ricardo Mendonça; Cartaz Verónica Guerreiro; Operador de Luz e Som - Adriana Vicente, Tiago Vasco.

Nuno S. Rodrigues

Agamémnon ou o crime (texto constituído a partir de M. Yourcenar, Clitemnestra ou o crime e de Yannis Ritsos, Agamémnon)

Produção: Escola de Mulheres

Encenação: Antonino Solmer $1^{\text {a }}$ Apresentação: Lisboa, Bairro Alto Data: 15.3 - 15. 4. 2001.

Agamémnon ou o crime é uma peça construída a partir de dois textos: Clitemnestra ou o crime de $\mathrm{M}$. Yourcenar, e Agamémnon do poeta Yannis Ritsos. Produzida pela companhia de teatro Escola de

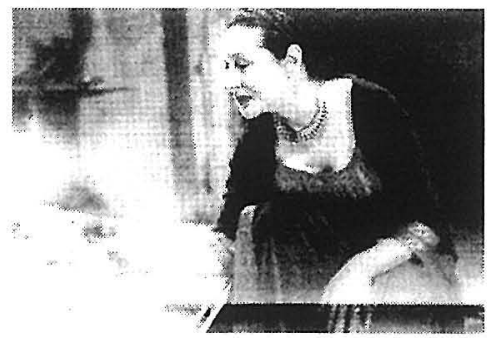
Mulheres, a peça esteve em cena no Palácio Marim Olhão, na Calçada do Combro, espaço pela primeira vez usado para este fim. A dependência da cozinha do palácio em ruínas, de estilo barroco, com uma abóbada de sete metros e uma escadaria, foi a opção acertada para sugerir o ambiente arruinado e decadente da Casa dos Atridas, marcada pelas consequências da guerra e da violência passional. De resto, estes são temas fortes de uma peça que procura mostrar a complexidade dos sentimentos e das motivações das 
personagens e a consequente dificuldade de ajuizar sobre as suas acções. $O$ cruzamento do texto de Yourcenar com o de Yannis Ritsos permite precisamente a apresentação dos dois lados do problema, que são ao mesmo tempo dois mundos de difícil interpenetração: o das mulheres e o dos homens. Clitemnestra é a mulher traída e desesperada que mata cruelmente o marido e nem assim apazigua o seu amor e o seu desejo de o matar; Agamémnon é um homem cansado, cansado da guerra inútil e cruel, e sem vontade sequer de vingança sobre a mulher.

Os monólogos de Clitemnestra, representada por Fernanda Lapa que também traduziu os textos, e de Agamémnon, desempenhado por António Rama, são auto-justificações e reflexões dirigidas a um grupo de "juízes" que, nesta encenação, é o conjunto dos espectadores. A fidelidade aos textos originais foi preocupação do encenador que, como o próprio afirmou, quis sobretudo dar voz aos actores: "É o teatro do actor e são eles que estão presentes."

Elenco: Actores - Fernanda Lapa, António Rama; Cenografia e Coordenação Técnica - Rui Pedro Pinto; Figurinos - Luísa Pinto; Luz - Carlos Gonçalves; Montagem de Banda Sonora - Paulo Curado.

Marta Várzeas

\section{PERSAS}

\section{Ésquilo, Os Persas}

Produção: Grupo Cénico SOIR

Encenação: Luís Varela

Iniciativa: $4^{\circ}$ Festival de Teatro Amador ( $4^{\circ}$ Fes.TA)

$1^{a}$ Apresentação: Lisboa, Auditório do Clube PT

Data: 11. 5. 2003.

M. F.S. S.

\section{PROMETEU}

\section{Ésquilo, Prometeu}

Iniciativa: Centro de Estudos Clássicos e Humanísticos (CECH)/Instituto de Estudos Clássicos

Apresentação: Coimbra, Instituto Justiça e Paz

Data: 9.3. 2001. 
No âmbito de uma sessão dedicada ao mito de Prometeu, intitulada "O fogo de Prometeu", foram lidos textos da peça esquiliana por actores da Escola da Noite, a acompanhar a conferência proferida pela $\mathrm{Dr}^{\mathrm{a}}$ Ana Paula Quintela Ferreira Sottomayor, investigadora do $\mathrm{CECH}$.

Maria do Céu Fialho

L. van Beethoven, $A$ Libertação de Prometeu (Abertura)

Iniciativa: Teatro Nacional de São Carlos / Teatro Municipal São Luiz

$1^{a}$ Apresentação: Lisboa, Teatro Municipal São Luiz

Data: 10. 10. 2003.

No âmbito do programa 'Cinco Pianistas Portugueses para os Cinco Concertos de Beethoven', promovido em parceria pelo Teatro Nacional de São Carlos, pelo Teatro Municipal São Luiz, em colaboração com a Câmara Municipal de Setúbal no plano das comemorações dos 250 anos do nascimento de Luisa Todi, realizou-se um concerto onde foi executada a abertura de $A$ Libertação de Prometeu de Beethoven. A execução musical coube à Orquestra Sinfónica Portuguesa do TNSC e a direcção musical ao Maestro Roberto Pollastri. Participaram ainda o pianista António Rosado, o clarinete Francisco Ribeiro e a soprano Teresa Cardoso de Menezes.

M. F. S. S.

\section{João Pedro D. d'Alcântara Gomes, Prometeu}

Produção: Teatro de Ferro/Casa das Artes de Famalicão/Apoio à Criação do Festival Internacional de Marionetas do Porto

Encenação: Igor Gandra

$1^{\text {a }}$ Apresentação: Casa das Artes de Famalicão

Data: 23. 1.2004

Outras: Casa d'Os Dias da Água, 31. 5. 2004 e 1. 6. 2004.

O Teatro de Ferro tem-se dedicado aos espectáculos de marionetas, que associam a encenações multimedia, tentando desse modo exprimir as suas concepções de modernidade e contemporaneidade. Este seu Prometeu é uma revisitação do mito grego, a história de um deus feito homem, agora expresso através da marioneta, com que se conseguem formas essencialmente geométricas, propulsionada directamente pela mão dos actores, que interage com a tecnologia, revelando-se assim um Prometeu no século XXI, com um vocabulário próprio. Segue-se deste modo uma linha de espectáculo já iniciada em outras encenações de temática não clássica. 
Inspirando-se no texto de Ésquilo, o Autor desta proposta de teatro de pesquisa escreve as seguintes palavras, que coloca na boca de Prometeu: «um sopro, um continuum desde as origens até ao final, quando acontecer; enquanto houver energia, enquanto os humanos continuarem o medo de se assumirem, a problemática de Prometeu é como a própria respiração».

Elenco: Ana Joana Amorim, Igor Gandra, Carla Veloso; Cenografia - Igor Gandra; Marionetas - Maria Jorge Vilaverde; Música Fernando Rodrigues; Video - Hugo Valter Moutinho; Movimento - Carla Veloso; Desenho de Luz - Virgínia Esteves; Direcção de Montagem Frederico Godinho; Oficina de Construção - Júlio Alves, Ricardo Graça, Artur Estanislau, Susana Veloso, Filipe Garcia, Octávio Oliveira; Design Gráfico - Miguel Neiva, Ícone Design.

Nuno S. Rodrigues

\section{Heiner Müller, Libertação de Prometeu}

Produção: Artmobil GmbH Frankfurt; Luciana Fina, Portugal

Concepção e Direcção: Heiner Goebbels

$1^{a}$ Apresentação: Lisboa, Teatro Monumental

Data: 27. 6. 1995

Outras: Porto (Teatro Rivoli), 28.11.1997; Coimbra (Instituto Justiça e Paz), 9. 3. 2001 (em projecção video).

A projecção foi feita a acompanhar a conferência do Dr. Carlos Guimarães, no contexto da sessão "O fogo de Prometeu" (vide vol. II, p. 35).

Maria do Céu Fialho

\section{Karl Orff, Prometeu}

Apresentação: Coimbra, Instituto Justiça e Paz (vide notícia anterior) Data: 9. 3. 2001.

A apresentação foi feita no contexto de uma conferência do musicólogo Doutor José Maria Pedrosa de Abreu Cardoso e constituiu uma parte da sessão "O fogo de Prometeu". 


\section{SETE CONTRA TEBAS}

As Máscaras e os Silêncios (texto adaptado de Sete contra Tebas de Ésquilo, Antígona de Sófocles, A origem da tragédia de Nietzsche e Antígona de J. Anouilh)

Produção: Grupo de Teatro Clássico Anankê Encenação: Henrique Martins

1. Apresentação: Lisboa, Auditório da Delegação Regional de Lisboa do Instituto Português da Juventude, ao Parque das Nações

Data: 24. 9. 1999

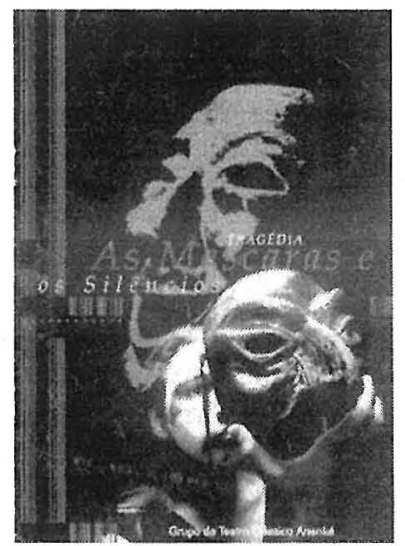

Outras: 25.9.1999 e 30.11.1999 (mesmo local).

Fruto de um trabalho experimental iniciado no âmbito de um Atelier de teatro clássico que decorreu de 6 de Fevereiro a 6 de Março de 1999, orientado por Henrique Martins, esta peça fundia textos de Os Sete contra Tebas de Ésquilo, da Antígona de Sófocles, de A Origem da Tragédia de Nietzsche e da Antígona de J. Anouilh. Levada à cena pelo Grupo de Teatro Clássico Anankê, a 24 de Setembro do mesmo ano, no auditório da Delegação Regional de Lisboa do Instituto Português da Juventude, esta era, de acordo com a classificação do encenador, uma "peça-estudo" que se inscrevia na ideia orientadora que esteve na génese deste novel grupo lisboeta. Sem a pretensão de fazer teatro clássico exactamente como teria sido no passado, o Grupo Anankê, ao formar-se, assumiu como principais objectivos especializar-se na arte específica de representar teatro clássico e criar um público para este tipo de teatro, que, no dizer de Jorge Angel Livagra, citado no programa, tinha "algo de mágico (...) de profundamente mistérico e fundamentalmente pedagógico".

Num cenário sóbrio e despojado de adereços, a figura nuclear do Coro, com vestes simples de cor preta e ostentando máscaras, dominava toda a acção que se centrava na tragédia dos quatro filhos de Édipo: Etócles, Antígona, Isménia e Polinices. As personagens que com ele contracenavam reflectiam, em quadros que se sucediam a bom ritmo, sobre o poder, a democracia, o direito e a justiça, temas que iam tecendo a teia trágica donde ninguém se conseguia desprender.

Elenco: Actores - Liliana Pereira (Antígona), Ália Montenegro (Isménia), Daniel Pais Filipe Gil (Polinice / Hémon / Sentinela 1), (Etéocles / Sentinela 2), Ana Filipa Carvalho (Espião/Coro), Rosa Martins (Mensageiro / Coro), Sara d'Andrade (Arauto / Coro), Henrique Martins (Creonte), Tânia 
Ferreira (Tirésias/Coro), Marta Pinheiro, Catarina dos Santos, (Coro); Cenografia, Luminotecnia, Sonoplastia e Guarda-Roupa- Grupo Anankê.

CARLOS MORAIS

AnanQUÊ? (inspirado em As Máscaras e os Silêncios do GTCAnankê, em $A$ origem $d a$ tragédia de Nietzsche, na Oresteia de Ésquilo e em Só para Mulheres de Aristófanes)

Produção: Grupo de Teatro Clássico Anankê

Ideia Original: Grupo de Teatro Clássico Anankê Autoria/adaptação de textos: Andrea Furtado Encenação: Andrea Furtado

1. ${ }^{a}$ Apresentação: Lisboa, Palco Oriental (perto do Convento do Beato)

Data: 12 . 12. 2003

Outras: 13, 19, 29.12 . 2003 (mesmo local).

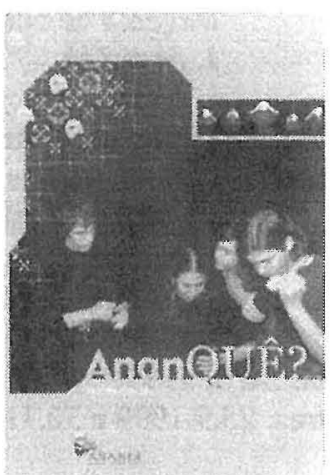

Anankê, conceito trágico que deu nome a um grupo de teatro clássico de Lisboa, deu também nome, através de um jogo de palavras, a uma peça produzida pelo referido grupo, da autoria de Andrea Furtado, que foi responsável também pela encenação. Contudo, "AnanQUÊ?" não era apenas o título para esta representação que misturava cenas da tragédia e da comédia gregas. Era também a pergunta que movia o grupo em torno de um projecto, a interrogação que o levava a ser perseverante e a manter-se fiel aos princípios que estiveram na base da sua formação: representar teatro de tema clássico e criar um gosto por este tipo específico de teatro.

Inspirada em As Máscaras e os Silêncios, em $A$ origem da tragédia de Nietzsche, na Oresteia de Ésquilo e em Só para Mulheres de Aristófanes, esta peça de teatro, estreada a 12 de Dezembro de 2003, prosseguia, assim, a experiência, iniciada em 1999, com a representação de As Máscaras e os Silêncios, no auditório do Instituto Português da Juventude de Lisboa.

Elenco: Actores de Tragédia - Hugo Sousa Nunes (Agamémnon), Andrea Furtado (Clitemnestra), Catarina Santos (Cassandra), Sara d'Andrade, Daniela Pires, Hugo Sousa Nunes, Frederico Sá Viana, João Pires (Coro); Actores de Comédia - Frederico Sá Viana (Eurípides), João Pires (Mnesíloco), Sara d'Andrade, Catarina Santos, Sílvia Coelho, Daniela Pires (Coro de Mulheres); Cenografia, Luminotecnia, Sonoplastia e GuardaRoupa-Grupo Anankê. 


\section{SUPLICANTES}

Borja Ortiz de Gondra, Exiliadas (Cantata para un Siglo), adaptação de Ésquilo, Suplicantes Produção: Grupo Atalaya (Sevilha)

Encenação: Ricardo Iniesta

Iniciativa: XXVI FITEI

$1^{a}$ Apresentação: Porto, Teatro São João

Data: 9-10. 6. 2003.

Este espectáculo parte das Suplicantes de Ésquilo, que mistura com textos de Maiakovski, Heiner Muller, Pablo Neruda e V. Pliestakia, para reproduzir a

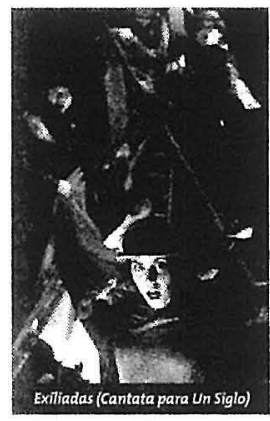
memória de um século de lutas femininas, numa alusão directa às grandes questões políticas e sociais do nosso tempo.

M. F. S. S. 
(Página deixada propositadamente em branco) 


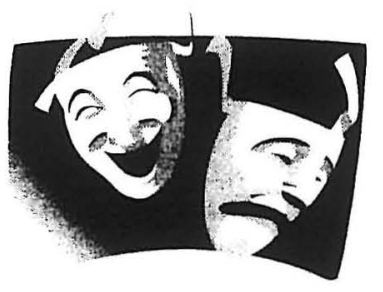

SÓFOCLES 
(Página deixada propositadamente em branco) 


\section{ÁJAX}

Sófocles, Ajax

Produção: RTP2

Realizador: Herlânder Peyroteo

Adaptação da tradução: Carlos Wallenstein

$1^{\text {a }}$ Apresentação: 7.8.1975

Outras: RTP, 18.4.2002, a propósito da homenagem a Herlânder Peyroteo.

Nesta representação para televisão a cenografia, da responsabilidade de Moniz Pereira, é extremamente sóbria e assenta no arranjo de alguns materiais têxteis, sugerindo redes, ou velas, ou materiais aparentemente mais consistentes, configurados de forma a sugerir a proa de um navio ou, remos, para evocar o espaço dramático, frente a Tróia, e caracterizar as personagens envolvidas na acção - Ájax, de Salamina, e o Coro dos Marinheiros de Salamina que o acompanharam até ali. Igualmente despojado é o guarda-roupa, concebido por Anahory. Os adereços devem-se a Ed. Ferreira Lda., Custódio Cardoso Pereira, Cutelaria Policarpo, Lda.

A caracterização foi supervisionada por Luís de Matos; Júlia Buisel foi a Anotadora; operou como Assistente de Realização Fernando Patrício. Os sons e música são de José Alberto Gil. A parte técnica do som é da responsabilidade de Jorge Teófilo, a mistura de Guerreiro Soares a iluminação de Fernando Rodrigues. O trabalho de filmagem contou com as câmaras de Gustavo Pavão, Carlos Gomes, Pinheiro de Araújo. A responsabilidade técnica coube a Hélder Duarte e o registo magnético é de Gomes Henriques.

A encenação opta pela representação, aos olhos do espectador, do suicídio de Ájax.

Elenco: Actores - João Perry (Ájax), Eunice Muñoz (Tecmessa), Lia Gama (Atena), Carlos Cabral (Menelau), Jorge de Sousa Costa (Agamémnon), António Rama (Menelau).

Maria do Céu Fialho

Heiner Müller, Ajax por exemplo (leitura de textos)

Produção: Artistas Unidos

Tradução: João Barrento

$1^{a}$ apresentação: Lisboa "N'a Capital", Teatro Paulo Claro

Data: 26. 4. 2000

Outras sessões de leitura: 24. 5. 2000.

Leitura de: Jorge Silva Melo 
Foram lidos alguns dos últimos textos de Heiner Müller, de que fez parte o seu Ájax, A morte de Séneca e $O$ bloco de Mommsen. Pretendeu o grande dramaturgo alemão recuperar a verdadeira história de Ájax e da Guerra de Tróia, do assassínio de Séneca às mãos de Nero e da proscrição de Mommsen.

\title{
Maria do Céu Fialho
}

\author{
ANTÍGONA \\ Sófocles, Antígona \\ Produção: Núcleo de Criação Teatral do \\ E.S.M.A.E. \\ Iniciativa: Porto 2001, Capital Europeia \\ da Cultura \\ Encenação: Nuno Cardoso \\ $1^{a}$ Apresentação: Porto, Teatro Helena \\ Sá e Costa \\ Data: 26 - 29. 4. 2001.
}

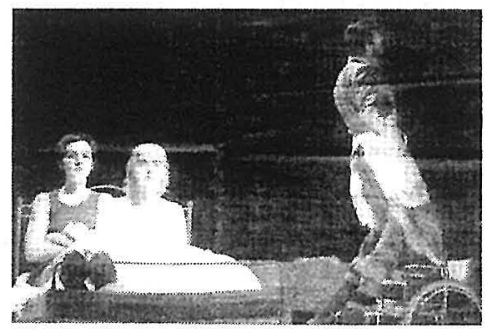

A peça escolhida por Nuno Cardoso para ser levada à cena por alguns actores recém-formados pelo Núcleo de Criação Teatral do E.S.M.A.E. foi a Antígona, considerada pelo encenador como "um dos textos emblemáticos da cultura ocidental", que, segundo ele, aborda temáticas de interesse para os jovens como "o poder, a razão de Estado, o indivíduo face ao poder, a revolta e a coacção". Foi, sem dúvida, por esta razão que fugiu a uma encenação clássica da peça. A acção desenrola-se num apartamento moderno, onde os adereços cénicos foram colocados no meio duma confusão propositada. Alguns deles são curiosos, como o televisor que transmite, em forma de noticiário, as falas de teor informativo; outros são gratuitos, como é o caso do frigorífico, donde continuamente se retiram cervejas, que, na opinião de Liliana Garcia (Público, 25.4.2001) servem para amansar "um povo carneirinho" - uniformizado pelo uso de óculos de lentes azuis espelhadas - ou bizarros, como a cadeira de rodas donde Eurídice apenas sai para girar, de forma extravagante, em cima duma mesa "como um bailarina de caixinha de música" (ibidem) ou até grotescos, como a sanita, o "trono" de Creonte, que, segundo a crítica acima referida, constitui o "abismo que separa Creonte de Hémon" e é a "metáfora da abjecção em que cai o poder gerido por mãos arrogantes".

Uma vez que o teatro é para Nuno Cardoso "uma boa forma de filosofar", a encenação pretende, decerto, ironizar a tirania, apresentando, por exemplo, Creonte entretido a fazer bolas de sabão, levando, conforme 
comenta Liliana Garcia, “à reflexão sobre a posição do indivíduo face ao poder" readaptando "à sociedade actual a fórmula «pão e circo»".

Não sendo, além do mais, o desempenho de nenhum dos actores digno de nota, o espectáculo, no seu conjunto, foi desconcertante e destituído de interesse.

Elenco: Actores - Célia Fechas (Eurídice), Hugo Cristóvão (Hémon/Coro), Hugo Mendes (Fagote), Hugo Sousa (Guarda), Hugo Torres (Creonte), Manuela Ferreira (Mensageiro/Coro), Marta Fernandes (Antígona/Coro), Rui Pena (Tirésias/Coro), Sílvia Silva (Ismena/Coro), Solange Sá (Estásima), Sónia Barbosa (Mensageiro/Coro); Música Albrecht Loops; Cenografia e Adereços - Fernando Ribeiro, Miriam Faria, Nuno Lucena; Figurinos - Maria Carlos Lima; Desenho de Luz - José Álvaro; Video - Eva Ângelo; Fotografia - Filipe Silva; Montagem - Sérgio Correia, Rui Seabra, Pedro Cabral, Manuel Alão, Ricardo Santos; Direcção de Cena - Ana Carolina Oliveira.

Ana Paula Quintela Sottomayor

Sófocles, Antígona

Produção: Teatro Focus

Encenação: Mário Trigo

1. ${ }^{a}$ Apresentação: Lisboa, Caves do Liceu Camões

Data: 11. 5. 2001

Outras: $12.5-10.6 .2001$ (de 6. ${ }^{\mathrm{a}}$ feira a

Domingo, no mesmo local)

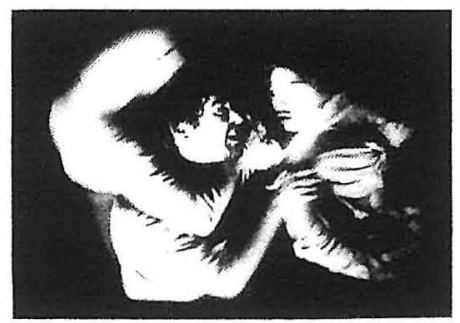

Nas caves do antigo Liceu Camões, o "Teatro Focus", com estreia a 11 de Maio de 2001, levou à cena uma adaptação da Antígona de Sófocles. Do original grego apenas interessava à encenação de Mário Trigo a questão nuclear e sempre actual da dicotomia entre o poder absoluto e arbitrário, representado por Creonte, e o poder individual, personificado em Antígona. Nesta adaptação, a filha de Édipo era a voz do indivíduo que defendia valores humanistas e representava o mundo privado da família e da consciência individual, onde cada um era livre de fazer a sua escolha. Encarnava, por isso, na interpretação do grupo, a posição política da "ética individualista", na medida em que, não sendo moralmente neutra, se responsabilizava perante o seu irmão como ser humano.

Para o público ficava a escolha da adequada solução política. Cabia-lhe decidir se se devia ou não lutar pelo respeito da individualidade de 
cada um. Da resposta decorria a inevitável assunção da legitimidade ou ilegitimidade do castigo de Antígona.

Tal actualização do texto sofocliano teve necessariamente implicações não só ao nível das referências espácio-temporais, que eram ignoradas, mas também ao nível da construção do texto, com a adopção de uma exposição contínua da argumentação das personagens, que seguia técnicas características do "teatro narrativo".

O "Teatro Focus", com esta leitura e interpretação do original grego, continuava uma reflexão sobre a posição do indivíduo face a qualquer instituição de poder, que iniciara com o espectáculo Salomé de Oscar Wilde.

Elenco: Actores - Paulo Reis, Pedro Alves, Rute Lizardo, Sérgio Afonso; Dramaturgia- Mário Trigo.

CARLOS MORAIS

Viagem à Grécia. Fragmentos e Antígonapara Sophia de Mello Breyner Andresen Produção: Companhia de Teatro Sensurround Direcção: Lúcia Sigalho Tradução: Lúcia Sigalho e Aris Tropakis

$1^{\text {a }}$ Apresentação: Lisboa, Armazém do Ferro da A. da Cabral Data: 3. 11 -2. 12. 2001.

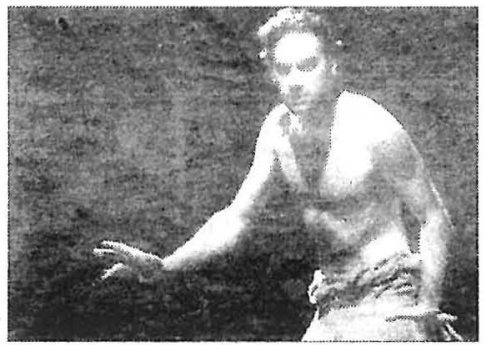

Após a experiência de uma viagem à Grécia - a sua primeira viagem à Grécia - Lúcia Sigalho dirigiu uma nova representação de Antígona de Sófocles. Para além do que de inovador possa ter trazido esta releitura da famosa tragédia, a originalidade deste espectáculo esteve sobretudo na precedência de um conjunto de leituras, que pretenderam recriar um contexto onde o mundo da cultura grega se instalasse em algumas das suas referências mais gritantes.

Ao penetrar no recinto obscuro e inconvencional do Armazém do Ferro, o espectador vê-se diante de um espelho de água, num longo espaço que o afasta de um remoto écran. Aí se irão movimentar os actores, antes de mais ainda não as personagens de Antígona, mas memórias vivas da paisagem física e cultural da Hélade. A exibição de um corpo nu, o marejar das águas com os movimentos de figuras humanas, a leitura de palavras de Sophia, sobre a Grécia, de Hesíodo ou de Aristóteles, o som da língua grega, ou o entoar de uma canção na mesma língua, procuraram criar um clima. 
Mesmo se nem tudo foi perfeito ou sugestivo neste tempo de abertura, a intenção não deixa de ser louvável.

Muito mais digna de aplauso, na nossa opinião, foi a representação de Antígona que se seguiu sem intervalo. Apenas uma adaptação de cenário, feita diante do público, delimitou a transferência. Vale a pena recordar como a deslocação de umas tantas placas flutuantes, sobre a toalha de água sempre presente, criou o chão de Tebas, na mesma ocasião em que o substituir de simples jeans e camisolas de lã por túnicas transformou os animadores da primeira parte em personagens da tragédia de Sófocles. O texto da tragédia foi cumprido na íntegra, na versão de Lúcia Sigalho e Aris Tropakis. O coro foi recriado por um grupo de cinco figuras, que se constituiu dos próprios actores, que, em marcações de cena muito felizes, se deslocaram entre as duas funções: de personagens e de coreutas. Algumas inovações profundas e modernas nos recursos de cena criaram efeitos de muito bom resultado. É esse o caso de um écran de televisão, que emitiu as ordens distantes da autoridade de Creonte; ou de um outro grande écran, ocupando o fundo do cenário, que funcionou de reflector de algumas imagens determinantes nos movimentos de cena.

Mas uma palavra de apreço merece sobretudo o trabalho de actores; para além do esforço desenvolvido por alguns actores de uma geração recente, as atenções confluem naturalmente para a interpretação que Fernanda Lapa faz de Creonte. Impondo ordens da distância de um écran ou do reverso de um negro muro de distância, este novo Creonte impõe-se pela vibração convincente da voz e pelo tom perfeito do discurso. Vê-lo-emos mais tarde diante dos nossos olhos, em trajo militar, ou despojado da samarra e da arrogância perante a ruína causada pela sua loucura condenável. De facto, notável esta interpretação da conhecida actriz. Mas muito destacada é também a intervenção do actor grego Aris Tropakis, que se impõe desde logo pela imponência natural da figura física, apoiada depois por uma real competência dramática. Cabe-lhe o papel do corifeu, onde dá o tom ao texto que ressoa nas palavras originais, na toada grega. Se algumas vezes, ao texto grego se sucedem, em tradução, notas fundamentais no sentido do texto, é sobretudo a musicalidade da língua grega que de facto se impõe nas intervenções corais. Mais tarde, compete-lhe também encarnar Tirésias. E este é, sem dúvida, o momento mais belo e plástico de toda a representação. Sobre uma mole negra, fortemente iluminadas, debatem-se a figura do adivinho, um esgalgado Tirésias, em contraste com um ainda recalcitrante Creonte, que começa a baquear sob o peso de ameaças cada vez mais sensíveis e próximas. Ao fundo, no grande écran, como sombras de mau agoiro, as mesmas duas figuras se reflectem a preto e branco, em negativo com a luminosidade da cena. Luz e sombras, tão presentes na dramaturgia de Sófocles, encontram aqui uma viva expressão plástica.

É, em conclusão, muito digna de aplauso esta representação que oferece a um público, que tem de ser erudito, uma visão da Grécia e das suas 
conquistas do espírito pelos olhos de quem delas colheu o encanto irresistível.

Elenco: Actores - Fernanda Lapa (Creonte), Lúcia Sigalho (Antígona, Eurídice), Aris Tropakis (Corifeu, Tirésias), Cláudia Jardim (Ismena), Nicolau dos Mares, Paulo Pinto, Rogério Nuno Costa, Sara Graça, Vítor Gonçalves; Cenografia e Vídeo - Alexandra Azinheira; Banda Sonora e Música Original - João Lucas; Desenho de Luz - Daniel Worm d'Assumpção; Adereços - João Figueira Nogueira \& Guilherme Strech; Roupas - Filipe Faísca.

M. F. S. S.

\section{Sófocles, Antigona}

Produção: Colégio da Rainha Santa Isabel

Encenação e Dramaturgia: Paulo Lavoura

Tradução: Maria Helena da Rocha Pereira

$1^{\mathrm{a}}$ Apresentação: Coimbra, Colégio da Rainha Santa Isabel

Data: 11-12. 4. 2002.

Elenco: Actores - Mariana Piçarra (Antígona), Paula Paiva (Ismena), José Luís Coelho (Creonte), João Santos (Hémon), Rita Carvalheiro (Tirésias), Ana Ribeiro (Eurídice), Daniel Roseiro (Guarda), Dina Gaspar (Primeiro Mensageiro), Telmo Barreira (Segundo Mensageiro); Coro - Ana Sofia Nicola, Sérgio Martins, Rafael Roque, Filipa Pinho, Miguel Ferro, João Martins, João Bernardes, Ana Barros, Anaisa Freitas, Maribel Carvalho, Hugo Almeida; Direç̧ão Artística - Artur Bessa; Cenografia - Nuno Pereira, Paulo Lavoura; Execução Cenográfica - Nuno Pereira, Rui Rolo, Paulo Pereira, Manuel Calado, Helena Calado, Paulo Lavoura; Design Gráfico - Nuno Pereira, Paulo Lavoura; Luminotecnia e Sonoplastia - Paulo Figueiredo, Paulo Lavoura, Ana Miguel.

Ana Paula Quintela

\section{Sófocles, Antigona}

Produção: Turma $12 .^{\circ}-7 .{ }^{\text {a }}$ (Humanidades) da Escola Secundária Dr. Manuel Gomes de Almeida, Espinho

Encenação: Prof. Agostinho Pinho

1. ${ }^{a}$ Apresentação: Espinho, Auditório da Junta de Freguesia

Data: 12. 3. 2004

Outras: Espinho (Escola Secundária Dr. Manuel Gomes de Almeida), 19. 3. 2004. 
A Antígona de Sófocles foi a peça escolhida pelos alunos de Humanidades $\left(12 .^{\circ}-7 .^{a}\right)$ da Escola Secundária Dr. Manuel Gomes de Almeida (Espinho), para, no âmbito da disciplina de "Oficinas de Expressão Dramática" (OED), trabalharem e apurarem a arte de representar, ao longo do ano lectivo de 2003/2004. Orientados pelo Prof. Agostinho Pinho, docente da disciplina, os alunos tiveram não só de se concentrar no aperfeiçoamento das suas qualidades histriónicas, mas também de se ocupar de todos os aspectos técnicos de uma encenação: sonoplastia, figurinos, luminotecnia, cenografia, guarda-roupa e adereços.

Os primeiros resultados do seu trabalho foram apresentados no palco do auditório da Junta de Freguesia de Espinho, perante uma plateia maioritariamente constituída por colegas, professores e familiares.

A escassez de meios e a circunstância de a turma ser constituída apenas por um reduzido número de elementos femininos limitaram um pouco o trabalho de encenação. Não obstante estas compreensíveis limitações, que obrigaram à substituição de um Coro actuante pela gravação com fundo musical de excertos dos cantos líricos, a representação decorreu com dignidade e algum ritmo, num cenário simples e com um guarda-roupa e adereços minimamente apropriados.

No capítulo da interpretação, destacou-se Geraldine García, no papel de Antígona, pelo movimento em palco, pela maleabilidade da expressão e pelo gesto adequado.

Apesar da reduzida formação teatral deste jovem grupo de alunos de Humanidades, a sua actuação, que se repetiu uma semana mais tarde nas instalações da sua Escola, não desmereceu.

Elenco: Actores - Geraldine García (Antígona), Cláudia Filipa Castro (Ismena/Mensageiro), Liliana Almeida (Creonte), Vânia Pereira (Corifeu), Karina Silva (Hémon), Márcia Silva (Guarda), Andreia Oliveira (Tirésias), Filipa Melo (Eurídice); Alexandra Castro, Cristina Fernandes, Helena Vasconcelos, Liliana Morais, Vera Dias; Sonoplastia, Figurinos, Luminotecnia, Cenografia, Guarda-Roupa, Adereços - alunos do $12 .^{\circ}-7$ a $^{\text {a }}$ da Escola Secundária Dr. Manuel Gomes de Almeida.

Sófocles, Anttgona

Produção: Grupo Balbo (Puerto de S. Maria, Cádis)

Iniciativa: IV Festival de Teatro Escolar de Tema Clássico

Encenação e Direcção: Emilio Flor

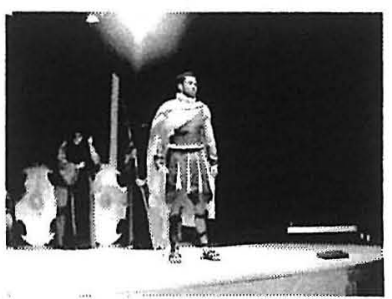


Iniciativa: IV Festival de Teatro Escolar de Tema Clássico 1. A Apresentação: Coimbra, Colégio de S. Teotónio Data: 28. 4. 2003.

Adoptando o nome da família responsável pelas reformas romanizadoras da antiga cidade do Gades, o Grupo Balbo é uma companhia que, desde 1974, encena peças de teatro greco-latino com o objectivo de estimular o gosto do público pelo mundo antigo, através desta forma particular de arte.

No ano das comemorações do $25 .^{\circ}$ centenário do nascimento de Sófocles, este grupo de Cádis trouxe a Coimbra, ao IV Festival de Teatro Escolar de Tema Clássico, a Antígona do tragediógrafo grego que, então, se homenageava.

Reproduzindo com grande fidelidade aspectos materiais do teatro grego, como o vestuário, os adereços e o cenário que adequadamente se caracterizavam pela simplicidade, o Grupo Balbo, dirigido por Emilio Flor, conseguiu transportar o espectador dos inícios do terceiro milénio para a Atenas do séc. V a. C., fazendo-o participar no conflito, sempre actual, entre a lei divina e a lei humana, o direito privado e o direito público, defendidos respectivamente pela intrépida Antígona e pelo inflexível Creonte.

Apesar de toda esta louvável fidelidade, o encenador assumidamente transgrediu, ao representar as mortes em cena, contrariando, assim, a tradição grega. Com esta prática do teatro romano, pretendia conferir à encenação o dramatismo que mais facilmente leva o espectador à catarse trágica. Este pormenor, discutível, não deslustra uma representação que se pautou por uma grande dignidade e rigor.

Elenco: Actores - Esther Pumar Reyes (Antígona), Antonio Pantoja (Creonte), Patricia López Ocaña (Ismena), Libertad Marín Rueda (Corifeu), Juan Lorca (Guarda), Antonio Zarola (Hémon/Etéocles/Coro), Francisco Rodríguez (Tirésias), Jesús María Gutiérrez Torres (Polinices/Mensageiro/Coro), María Serpa Mora, Antonio Zarola (Coro), Miriam Perea (Eurídice).

CARLOS MORAIS

\section{Sófocles, Antigona}

Produção: A Capoeira (Companhia de Teatro de Barcelos)

Encenação: Fernando Pinheiro

Iniciativa: XIV Festival de Outono (ARTAM, Associação Regional de Teatro Amador do Minho)

Data: Outono de 2003. 
Com esta produção o grupo Capoeira completava uma trilogia clássica dedicada à condição feminina, de que constaram, além da peça de Sófocles, $A$ Casa de Bernarda Alba de Garcia Lorca e As Troianas na versão Eurípides / Sartre. A representação da Antígona valeu ao grupo cinco distinções: Melhor Encenação 2003, Melhor Espectáculo 2003, Melhor Realização Técnica 2003, Melhor Interpretação Masculina 2003 e Melhor Interpretação Feminina 2003.

Elenco: Actores - Sofia Oliveira (Antígona), Susana Pinheiro (Ismena), Fernando Pinheiro (Creonte), Vítor Pinto e Vítor Fernandes (Guarda-costas), António Alves (Guarda), Tiago Ferreira (Hémon), Pedro Pedro (Tirésias), Diogo Pinto (Menino), Vítor Fernandes (Mensageiro), Luísa Gomes (Eurídice); Coro - Luísa Reininho, Carla Cardoso, Sónia Costa, Egídia Sarmento, Ana Gomes, Mariana Nogueira; Cenografia - Fernando Pinheiro, Hilário Portela; Adereços - Luísa Reininho, Luísa Gomes; Figurinos - Susana Pinheiro, Sofia Oliveira; Música - Fernando Pinheiro; Desenho de Luz - Fernando Pinheiro, Mário Mano Maciel; Operador Técnico de Luz e Som - Mário Mano Maciel; Confecção de Máscaras Luísa Reininho, Luísa Gomes, Egídia Sarmento.

M. F. S. S.

\section{J. Anouilh, Antigona}

Produção: O Grito

Encenação: Anabela Esteves

$1^{\text {a }}$ Apresentação: Almada, Teatro Estúdio

Data: 29.11 - 15.12. 2002 ( $6^{\mathrm{a}}$ a domingo).

Elenco: Actores - Eunice Martins, José Vaz, José Henrique Neto, Andreia Egas, Paulo Brito.

Ana Paula Quintela

\section{J.Cocteau et J.Anouilh, As Ant'gonas Produção: STAN \\ Encenação: colectiva \\ $1^{\text {a }}$ Apresentação: Lisboa, Teatro da Garagem Data: 5-8. 6. 2002.}

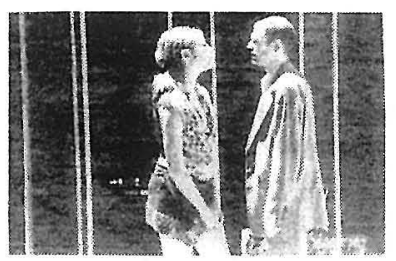

A principal característica deste grupo belga de teatro parece ser a originalidade, a começar, desde logo, pelo nome, constituído pelas iniciais 
S(top) $\mathbf{T}$ (hinking) $\mathbf{A}$ (bout) $\mathbf{N}$ (ames), e ainda pelo facto de não possuir encenador, havendo apenas "princípios de trabalho, que passam pelo colectivo", acontecendo, por isso, "o espectáculo pela primeira vez no palco, durante a estreia",o que faz com que seja "diferente todas as noites", no dizer do actor português Tiago Rodrigues, que integra os STAN desde 1997. Igualmente peculiar foi a opção de apresentar ao público não uma Antígona, mas duas, ligando ao texto de Cocteau "compacto e curto, que daria uns 20 minutos de espectáculo", conforme referiu, em entrevista ao $D N(5.6 .2002)$ Frank Vercruyssen, a peça de Anouilh, a que se juntaram ainda alguns ingredientes sofoclianos. Em crítica publicada no Expresso (15. 6. 2002) é salientada "uma muito notável apropriação do texto por parte dos actores". As peças foram representadas na língua original, e não em inglês, como seria de esperar desta companhia flamenga. Depois de Jolente de Kersmaeker apresentar o espectáculo, os actores e personagens, começa a desenrolar-se, em jeito de prólogo, a peça de Cocteau, tendo como único elemento cénico uma mesa e algumas cadeiras; na restante parte do espectáculo, o cenário inexistente é sugerido pela forma como os actores ocupam os espaços. $\mathrm{O}$ elenco é constituído apenas por cinco actores: os já referidos Tiago Rodrigues, Frank Vercruyssen e Jolente de Kersmaeker (que, além da apresentação, tem a seu cargo também os papéis de coro e de ama), Tine Embrechts, também belga, e a norueguesa Natali Broods.

Ana Paula Quintela

\section{A. Pedro, Antigona}

Produção: Grupo de Teatro da Vitorino Nemésio

Responsável pelo Grupo: Lurdes Castanheira $1^{a}$ Apresentação: Escola Secundária Vitorino Nemésio

Data: 1987-1988.

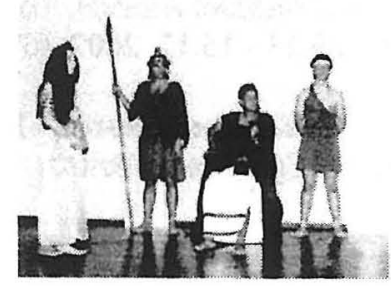

M. F. S. S.

António Pedro, Anttgona

Produção: Grupo "Natural Invenção", da Escola Secundária Cristina Torres

(Figueira da Foz)

Iniciativa: XXIV Jornadas de Teatro Amador da Figueira da Foz

Encenação: Vítor Marques

1. apresentação: Casa do Povo de Lavos

Data: 5. 5. 2001 
Outras: Cantanhede (Escola Secundária de Cantanhede, numa iniciativa da Escola Básica 2,3 de Cantanhede), 25. 5. 2001; em Maio e Junho, outras representações no Concelho da Figueira da Foz e uma em Coimbra (Escola de Enfermagem, em S. Martinho do Bispo).

No âmbito das XXIV Jornadas de Teatro Amador da Figueira da Foz, o Grupo "Natural Invenção" levou à cena, na Casa do Povo de Lavos, a "Glosa Nova" da Antígona de Sófocles dua autoria de António Pedro. Ainda que não se possa afirmar que esta recriação, em termos estruturais, representa um corte com o modelo grego, muitas foram as liberdades a que o autor, como homem do teatro, deitou mão para cumprir o objectivo de adaptar a tragédia grega ao gosto teatral do público de meados do séc. XX. Nesta sua preocupação pedagógica de actualizar uma peça produzida na Atenas do séc. $\mathrm{V}$ a. C. inscrevem-se quer a introdução de novas personagens e a simplificação do coro em termos de linguagem e de coreutas, quer, sobretudo, a introdução de um prólogo expositivo, didascálico e metateatral. É neste "prólogo-parábase" sobre o funcionamento do espectáculo teatral que são fornecidas ao público informações que visam integrá-lo na acção que se vai desenrolar. À medida que se retoca e monta o cenário, discute-se aspectos da encenação, situa-se a acção, expondo-se os seus antecedentes, e apresentase as personagens.

Foram todas estas adaptações, associadas a uma linguagem actual e simplificada, que fizeram com que esta peça fosse muito apreciada, tornando-se, assim, na mais representada de todas as recriações que, ao longo do séc. XX, foram produzidas a partir do modelo sofocliano.

Não se afastando muito do proposto por António Pedro, nas suas didascálias pormenorizadas e, por vezes, algo extensas, a encenação de Vítor Marques não deixou de inovar, ao introduzir, logo após o prólogo, uma cena espectacular de luta, com muito movimento, cor e som, proporcionados por fogo em palco, por conseguidos jogos de luzes e por intensos apontamentos musicais.

Num cenário que procurava reproduzir o ambiente clássico em que decorria a acção, e com um guarda-roupa simples como convinha, as personagens representaram com acerto esta tragédia que o Coro, usando máscaras, definiu como "tragédia da liberdade".

Elenco: Actores - Hélia Carvalho (Antígona), Carlos Santos (Creonte), Sónia Antunes (Tirésias), Silvéria Ramos (Eurídice), Alexandra Lima (Isménia), Liliana Costa (Artemísia), Ricardo Patrão (Hémon), Marta Rodrigues (1. ${ }^{\circ}$ Velho), Inês Mendes (2. ${ }^{\circ}$ Velho), Mónica Louro (3. ${ }^{\circ}$ Velho), Ana Maria Gonçalves (Encenador), Jael Palhas (1. ${ }^{\circ}$ Soldado), Joana Moço (2. ${ }^{\circ}$ Soldado/Pregoeiro), Vítor André Dinis (Carpinteiro), Luís Sousa (Electricista); Caracterização - Silvéria Ramos/Celeste Freitas; SonoplastiaLuís Sousa; Luminotecnia - Vítor Marques; Música - Ardetti String Quartet 
e Anouar Brahem Stephen Micus; Guarda-Roupa - Colectivo; Ponto Celeste Freitas.

CARLOS MORAIS

\begin{abstract}
António Pedro, Antígona
Encenação: Filipe Jorge e Patrícia Martins

Data: 21. 4. 2002

Outras: Mealhada (Complexo Turístico dos Três Pinheiros, no âmbito das "Escolíadas 2002"), 3 .5. 2002; Aveiro (Escola Secundária Homem Cristo), 16. 5. 2002; Vagos (Escola Secundária de Vagos), 16. 5. 2002; Conímbriga (Museu de Conímbriga, no âmbito do IV Festival Internacional de Teatro de Tema Clássico), 22. 6. 2002.
\end{abstract}

Produção: Teat@amus, Núcleo de Teatro do Colégio de Calvão

1. ${ }^{a}$ Apresentação: Calvão, Colégio N. S. ${ }^{a}$ da Apresentação

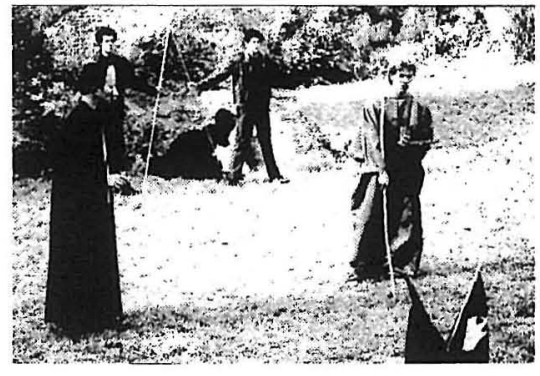

Formado há aproximadamente nove anos com o propósito de oferecer aos jovens alunos do Colégio de Calvão um complemento de formação teatral e de, por esse meio, concorrer também para a ocupação dos seus tempos livres, o Teat@amus ostenta já um repertório digno de menção, que inclui representações de várias peças, das quais se destacam $O$ Rouxinol e a Rosa, A Canção de Natal, Romeu e Julieta, O Principezinho, A Gota de Mel, Guerra Santa, Antígona e Rei Édipo.

Para a sua primeira experiência de representação de teatro de tema clássico, a peça eleita foi a Antígona, levada à cena pela primeira vez, no Colégio de Calvão, a 21 de Abril de 2002. Não a Antígona sofocliana, mas a recriação que dela fez António Pedro, uma "Glosa Nova" escrita expressamente para ser representada pelo Teatro Experimental do Porto, na década de 50, com uma linguagem actual e dramaticamente funcional muito apreciada, que fez com que se tornasse na mais representada das recriações portuguesas da Antígona de Sófocles.

Com uma adequada encenação da responsabilidade de Filipe Jorge e de Patrícia Martins, a peça, depois da estreia e de duas representações em Escolas do distrito de Aveiro, abriu o IV Festival Internacional de Verão de Teatro de Tema Clássico, em Conímbriga, a 22 de Junho de 2002.

De referir ainda que o grupo, a partir do texto de António Pedro, criou uma adaptação/síntese, intitulada Creonte, para integrar a edição de 
2002 das Escolíadas, que decorreu no complexo turístico Três Pinheiros, na Mealhada, a 3 de Maio de 2002.

Elenco: Actores- Carla Rosete (Antígona), António José Simões (Creonte), Sara Leigo (Isménia), Ângelo Valente (Tirésias), Lilibel Valente (Eurídice), Bianca Barros (Artemísia), Carlos Carvalhais (Hémon), João Vítor (Soldado 1), Pedro Reis (Soldado 2), Carina Alves, Simone Miranda, Susana Diamantino (Coro); Direcção de Actores - Filipe Jorge, Patrícia Martins; Cenografia - Carlos Jesus, alunos do Agrupamento 2; GuardaRoupa - D. Rosa; Iluminação - Pedro Neto; Composição Musical - Paulo Henrique, Pedro Neto, Fernando Ferreira.

CARLOS MORAIS

Jean Anouilh e António Pedro, Antigona

Produção: Oficina de Expressão Dramática de Margarida Tavares, com a turma $12^{\circ} \mathrm{H}$

$1^{a}$ Apresentação: Torres Vedras, Escola Secundária Madeira Torres

Data: 29, 31. 5. 2002

Outras: Óbidos, Junho de 2002.

Com base nos textos de Jean Anouilh e de António Pedro, dramaturgos que no século XX reescreveram a Antígona de Sófocles, uma turma do $12^{\circ}$ ano da Escola Secundária Madeira Torres, em Torres Vedras, levou à cena, em dois dias diferentes, a Antígona. Esta representação dos alunos inseriu-se no projecto da Oficina de Expressão Dramática da professora Margarida Torres.

Susana Hora Marques

António Pedro, Antígona (glosa nova da tragédia de Sófocles)

Produção: Teatro Experimental do Porto

Encenação: Norberto Barroca

Iniciativa: Comemoração de 50 anos de espectáculos do TEP

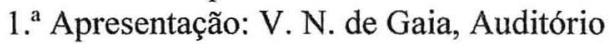
Municipal

Data: 24. 5. 2003-18. 6. 2003 (de quarta-feira a Domingo, no mesmo local).

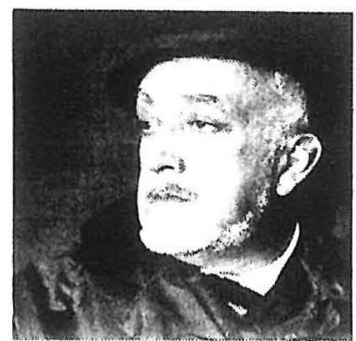


Para assinalar os 50 anos de espectáculos, que se completaram a 18 de Junho de 2003, o Teatro Experimental do Porto levou à cena, no Auditório Municipal de Gaia, a Antígona de António Pedro, uma peça que fora escrita expressamente para este grupo e que fora representada nos primórdios da sua existência, em 1956 e em 1956/1957 (respectivamente, $2 .^{\circ}$ e 7. ${ }^{\circ}$ espectáculos) ${ }^{1}$. Com esta escolha, plena de significado, o TEP, além de assinalar um ciclo memorável de 193 representações, homenageava também o autor e "homem de teatro completo" que, durante uma década (1953-1962), marcou de forma indelével a história daquela que é a mais antiga das companhias de teatro profissional existentes em Portugal.

Fazendo uso dos figurinos da reposição de 1956/1957, criados por Augusto Gomes, que assim também era alvo de justa homenagem, a representação, sempre realçada por bem desenhados jogos de luzes, decorreu com dignidade e acerto, num cenário sóbrio, como convinha, não muito distante do que concebera António Pedro para as suas encenações.

No capítulo da interpretação, ainda que todos estivessem a bom nível, são merecedoras de uma referência especial quer a actuação do Coro dos Velhos pela clareza das suas elocuções e pela forma como se movimentou em palco e soube gerir os silêncios, quer o desempenho de Susana Sá, no papel de Antígona, pela adequada colocação de voz, pelo gesto apropriado e pela densidade dramática que conseguiu imprimir às suas intervenções.

Pena foi que, nesta encenação de Norberto Barroca, contrariando de certo modo o sentido profundo do texto, se tivesse retirado toda a intensidade plástica e patética à cena do acto III, em que Artemísia, desvairada, exibe as suas mãos com o sangue já frio do jovem Hémon que muito amara. Ausente do original grego, este quadro, de rara beleza e originalidade, teve nas encenações de António Pedro um tratamento adequadamente mais impressivo, que, na altura, mereceu da crítica rasgados elogios ${ }^{2}$.

Elenco: Actores - Norberto Barroca (Encenador/Creonte), Adriano Martins, José Cruz, Augusto Martins (Coro dos Velhos de Tebas), José Brás (Tirésias), Olga Martins (Artemísia), Susana Sá (Antígona), Andreia Vasconcelos (Isménia), Vítor Nunes (Pregoeiro/2..$^{\circ}$ Soldado), Rui Silva (Hémon/Assistente de Palco), Luís Gonzaga ( $10^{\circ}$ Soldado/Assistente de Palco), Alice Vasconcelos (Eurídice); Figurinos - Augusto Gomes; Cenário- Norberto Barroca, Mário Dias Garcia; Desenho de Luz,

\footnotetext{
${ }^{1}$ Vide Maria de Fátima Sousa e Silva (coord.), Representações de Teatro Clássico no Portugal Contemporâneo, Coimbra, Colibri, 1998, I: 59-62.

${ }^{2}$ Vide Carlos Morais, "A Antígona de António Pedro: liberdades de uma glosa", in Máscaras Portuguesas de Antígona, Aveiro, 2001, p. 97, n. 45.
} 
Sonoplastia- Eduardo Brandão; Assistente de Encenação e Director de Cena- Rui Silva; Operador de Som-António Cardoso; Operador de LuzJoão Abreu; Maquinaria- Alberto Ribeiro, Manuel Neves; Guarda-RoupaJoaquina Garcia; Execução do Cenário- Auditório Municipal de Gaia/Oficinas; Adereços- António Cardoso, José Cruz.

CARLOS MORAIS

António Pedro, Antígona - Glosa Nova da Tragédia de Sófocles Produção: Turma $11^{\circ} \mathrm{F}$ da Escola ES/ 3 de Artur Gonçalves, Torres Novas e Professora de O.E.D. Cidália Ventura Encenação: Celina Moura $1^{\text {a }}$ Apresentação: Torres Novas Data: 2. 4. 2004.

Antígona nunca morre. Esta controversa figura serviu ao longo de séculos e séculos os mais variados

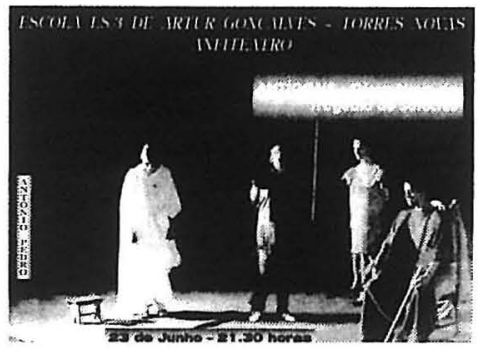
intentos de vários autores nacionais e estrangeiros. Numa reescrita mais ou menos livre, Antígona permanece para nos transmitir vários ensinamentos e incutir determinados valores. António Pedro, mais uma vez, à semelhança de Sófocles, deu-lhe voz como instrumento político e fê-la brilhar.

Antígona voltou a brilhar, em Torres Novas, pelas mãos de um grupo de jovens do $11^{\circ}$ ano, da Escola ES/3 de Artur Gonçalves, no âmbito da disciplina de Oficina de Expressão Dramática. O caminho percorrido foi sinuoso, com muitas angústias, dúvidas e incertezas, mas o produto final foi apresentado com paixão. Perguntamos nós: o que levou este grupo de adolescentes a amar Antígona? Como surgiu tanto entusiasmo por um texto que, como costumam dizer, "cheira a mofo"?

A resposta é simples, os grandes clássicos, tal como Antígona, nunca morrem, basta tirá-los da prateleira e dar-lhes o sopro de vida que necessitam; a partir daí tudo é simples. Além disso, um dos principais traços do carácter de Antígona é a rebeldia. E o que são os nossos jovens senão saudáveis rebeldes? Apaixonaram-se por ela, viveram-na intensamente e deram-lhe uma nova alma, a da rebeldia da adolescência com uma força interior fantástica.

Seguiu-se o texto de António Pedro na íntegra. O cenário era simples, quase vazio, predominando o tom vermelho, alternando com a luz azul do céu e o verde angustioso de algumas tiradas dos velhos. Faltou mesmo a oportunidade ao ar livre, num pequeno anfiteatro existente na 
escola, mas a chuva não o permitiu; limitámo-nos então ao Ginásio da Escola. $\mathrm{O}$ guarda-roupa foi clássico, gentilmente cedido pelo grupo de Teatro Clássico da Faculdade de Letras da Universidade de Coimbra. O vestido de Antígona, agradecemos a Hélia Correia o tê-lo cedido ao Instituto de Estudos Clássicos da Faculdade de Letras de Coimbra, o que nos permitiu utilizá-lo.

Valeu a pena? Como diz Pessoa "Tudo vale a pena / Se a alma não é pequena.". Fazer com que dezanove jovens ficassem apaixonados por Antígona, abrir-lhes o caminho para outros textos clássicos, colocar-lhes no coração este "bichinho"... só por isso e muito mais, valeu a pena!

Elenco: Actores - Lúcia Luz (Chefe Maquinista / Uma voz), Sílvio Correia (Electricista / Outra voz), Maria Ruivo (Artemísia), Joana Ruivo (Antígona), Vera Matos (Isménia), Ana Catarina Gomes (Eurídice), Fábio Mendes (Creonte), Marina Silva (Hémon), Andreia Gonçalves (Tirésias), Ana Conde (Pregoeiro), Eunice Santos (Soldado), Mariana Ruivo, Sofia Rodrigues (Guardas); Coro de Velhos - Joana Pereira ( $1^{\circ}$ Velho), Úrsula Oliveira ( $2^{\circ}$ Velho), Elisabete Lavado ( $3^{\circ}$ Velho); Colaboração nos Bastidores - Kelly Novais, Sílvia Bento.

Cidália Ventura

\section{?, Antigona}

Produção: Col. Som e Imagem, IEC

Realização: Jean-Marie Straub e Danièle Huillet

$1^{\text {a }}$ Apresentação: TAGV

Data: 15. 11.2001.

Ana Paula Quintela

\section{ELECTRA}

Sófocles, Electra

Produção: Grupo Calatalifa (Madrid)

Encenação: Pedro Saenz de Almeida Iniciativa: III Festival Escolar de Teatro de Tema Clássico

$1^{\text {a }}$ Apresentação: Coimbra, Museu Nacional Machado de Castro

Data: 2. 5. 2002

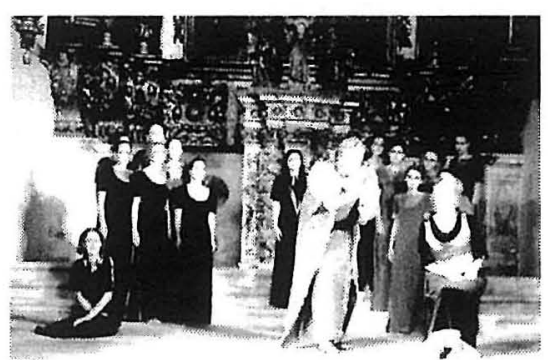

Outras: Conimbriga, 14. 5. 2004. 
A "Electra" de Sófocles tem sido tradicionalmente considerada como a mais perfeita das suas obras, quanto à estrutura dramática. Ao longo do texto vão-se contrapondo de forma excelente os matizes dramáticos de obscuridade e luz, assimilados respectivamente aos conceitos de dor, crime e injustiça, de um lado, e vingança, restauração e liberdade, do outro.

Mesmo assim, encontramos neste drama outra oposição entre verdade dramática e mentira cénica que aparece como 'jogo de espelhos'.

Mas, de modo paradoxal, a diáfana e envolvente estrutura dramática desta tragédia serve para nos introduzir num mundo fronteiriço com o do reino dos mortos e das divindades infernais, a cujo cargo está a vingança justiceira que dá repouso aos defuntos: Electra, no meio da sua dor e da sua vida miserável, vive para a recordação do seu pai assassinado e acumula rancor contra a mãe e desejos de vingança contra ela.

Electra, como leoa ferida, encarna as mais obscuras, violentas e elementares forças da natureza. Por seu lado, o irmão Orestes representa o modelo do herói apolíneo, forte e despreocupado, belo e cheio de luz, mesmo quando, cumprindo o oráculo de Apolo, mata a mãe para vingar o assassinato de seu pai.

Em volta dos dois irmãos movem-se as demais personagens, magistralmente caracterizadas, combinadas e dispostas por Sófocles dentro de uma acção dramática que, concebida como uma caçada, avança directamente para a armadilha final em que os assassinos pagarão o seu crime. Com a morte de Clitemnestra e do seu amante Egisto, resolve-se o conflito que abre e põe em marcha a tragédia: o crime tem de se pagar com o crime. A vingativa Némesis do morto fica assim aplacada.

A representação distingue-se pela movimentação do Coro que usa uma dupla máscara, provocando um efeito de surpresa, quando os coreutas se voltavam. Merece também realce o vestuário e a coreografia.

A elocução do texto de Sófocles, em versão de Pedro Sáenz Almeida, foi clara e expressiva. Teve qualidade a interpretação do papel do Pedagogo e de Electra.

O grupo, agora com o nome de Arthistrión/Calatalifa, voltou a apresentar a Electra de Sófocles em Conimbriga, na Casa dos Repuxos, em 14 de maio de 2004, com algumas alterações, como a ausência de máscara e substituição de alguns actores. São da representação de 2004 o elenco e a ficha técnica que apresentamos a seguir. Destaco, no entanto, a extraordinária interpretação da figura de Electra por Susana Verdú, que conseguiu dar com perfeição as cambiantes de tristeza, dor, desespero e alegria que a figura vai reflectindo, à medida que escuta a narração do Pedagogo, relativa à morte fictícia de Orestes, e que sabe que o irmão está vivo e se encontra na sua presença.

Elenco: Actores - Susana Verdú (Electra), Javier Oleaza (Pedagogo), Luis Jiménez (Orestes), Carlos Martos (Pílades), Susana Millán (Crisótemis), Alba 
Alonso (Clitemnestra), Raúl Verdú (Egisto), Lucía Díaz (Corifeu). Coro Débora Mamblona, Alba Rodríguez, Patricia Martínez, Paola Martínez, Juan José Sánchez, José Herradón, Pablo Martínez, Victor de Castro; Figurinos e Adereços - Javier Botella; Realização do Vestuário - Ruth Patricia Sánchez; Escultura Cénica - José Luis Táboas Nogueira; Coreografia - Susana Verdú Martínez; Cenografia - Arthistrión/Calatalifa; Música - Goldenthal, Terzis, Pook, Mussorgsky, Kilar, Williams, Mozart, Janácek; Iluminação e Som: Sonia García Lázaro; Coordenação - Luis Jiménez / Susana Verdú; Produção - Arthistrión Asociación Cultural; Direcção - Pedro Sáenz Almeida, Susana Verdú Martínez.

José Ribeiro Ferreira

\section{FILOCTETES}

Heiner Müller, Filoctetes

Produção: Artistas Unidos

Encenação: Jorge da Silva Melo, com a colaboração de Jorge Andrade e Pedro Carraca

$1^{a}$ Apresentação: Lisboa, Teatro Paulo Claro, Espaço A Capital

Data: 11. 4. 2002

Outras: até 19 de Maio.

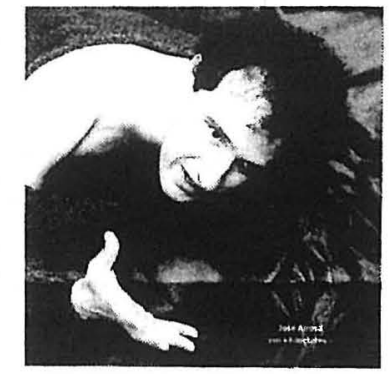

Em Maio de 2002, com encenação de Jorge da Silva Melo e Jorge Andrade, os Artistas Unidos prepararam e apresentaram, no Teatro Paulo Claro, Espaço A Capital, em Lisboa, o Filoctetes de Heiner Müller, uma versão próxima da tragédia de Sófocles sobre o herói grego desterrado na ilha de Lemnos, para problematizar em especial o drama do homem solitário, traído pelos seus. Heiner Müller, com leves mas significativas alterações no mito, embora com final muito diferente, joga na ambiguidade da peça e opera transformações nas figuras, que têm permitido díspares interpretaç̃os no contexto político actual. Perante a necessidade da presença em Tróia de Filoctetes e do seu arco infalível, para que a cidade pudesse ser conquistada, Ulisses e Neoptólemo vêm buscá-los, mediante um ardil e uma cilada, cuja execução fica a cargo do filho de Aquiles. Mas em breve no espírito do jovem se instala o conflito que o leva a pretender devolver o arco. Embora o rei de Ítaca tente evitar essa entrega do arco, Filoctetes consegue recuperá-lo, aproveitando a luta que se trava entre os dois, e apresta-se a matar o Cefalénio. Então, para salvar o companheiro, Neoptólemo acaba por apunhalar o herói desterrado, o que leva Ulisses a declarar: «Aprendeste bem 
depressa a minha lição». Com novo ardil que torne útil o cadáver, o rei de Ítaca propõe que se conte ter sido a morte provocada pelos Troianos. E no final do drama do autor alemão, Filoctetes sai de Lemnos morto, ao contrário do que acontece na tragédia de Sófocles.

Assim, no Filoctetes de Heiner Müller, Filoctetes o homem impoluto, mas desadaptado do seu tempo, recusa voltar a colaborar com o povo que $o$ traiu e sobretudo com o responsável dessa traição; Ulisses é o político pragmático que recusa as questões pessoais e elabora uma argumentação implacável contra o caso individual de Filoctetes; Neoptólemo, o jovem inocente com as mãos manchadas de sangue, incarna a tragédia da consciência, da lealdade, do dever.

Afirma Jorge Silva Mello que com a encenação de Filoctetes quis mostrar a provocação de Heiner Müller: que «a mentira é indispensável, assim como a traição. E não querer ver isto é ser moralista, farisaico».

As figuras de Filoctetes, Ulisses e Neoptólemo são interpretadas por José Airosa, Américo Silva e João Meireles, respectivamente. Sobre a sua interpretação, escreveu João Carneiro no Cartaz do Expresso, de 27. 4. 2002: «Américo Silva utiliza uma maneira de dizer que acentua e, principalmente, divide o texto de uma forma algo incómoda para quem ouve. João Meireles é um óptimo Neoptólemo e José Airosa um Filoctetes absolutamente exemplar.»

A tradução esteve a cargo de José Maria Vieira Mendes que verteu para verso alexandrino os decassílabos do texto alemão. O cenário - destroços sob fundo azul - e os figurinos foram concebidos por Rita Lopes Alves, Rosa Lopes Alves e José Manuel Reis. A iluminação era da responsabilidade de Pedro Domingos.

José Ribeiro Ferreira

\section{REI ÉDIPO}

\section{Sófocles, Oedipus the King}

Produção: Crossroads World Film Services, Universal Pictures, Michael

Luke

Data da Produção: 1967

Direcção Cinematográfica: Philip Saville

$1^{\text {a }}$ Apresentação: Cinemateca Portuguesa- Museu do Cinema

Data: 5. 12. 2003.

Apesar de ser uma excelente adaptação da tragédia de Sófocles ao cinema, com duas magníficas interpretações de Christopher Plummer e de Orson Welles, como Édipo e Tirésias, respectivamente, esta realização de P. Saville não é muito conhecida do grande público (não consta mesmo da lista 
quase exaustiva elaborada por R. De España) e, até Dezembro de 2003, era mesmo inédita em Portugal. A proposta cinematográfica de Saville anda muito próxima do texto sofocliano, obedecendo sobretudo a uma linguagem teatral e centrando-se a maioria das cenas num teatro grego, conseguindo-se assim uma das melhores revisitações da tragédia grega feitas no século XX.

Nem Salville, com a sua leitura quase arqueológica do texto, porém, conseguiu escapar a um ou outro aspecto mais popular e «cinematográfico», como indica a cena do beijo trocado entre Édipo e Jocasta, na intimidade dos seus aposentos, completamente desnecessário para a economia do texto e do argumento, mas eficaz do ponto de vista do impacte popular. De qualquer modo, não nos parece que Salville tivesse alguma vez tido a intenção de realizar um filme «popular». De qualquer modo, a força das interpretações, de que já mencionámos algumas, muito em especial a de $\mathrm{O}$. Welles como o adivinho cego, ganham completamente o filme. Poderíamos mesmo dizer que a curta participação de Tirésias/Welles rouba toda a película ao restante dos actores, Plummer incluído.

Esta exibição, em Lisboa, foi feita no âmbito das comemorações dos 2500 anos do nascimento de Sófocles, sendo este Oedipus the King exibido juntamente com outras produções dedicadas ou adaptadas de obras do dramaturgo grego. No caso deste Oedipus, a apresentação coincidiu com o ciclo "Orson Welles no século XXI: o Labirinto sem centro», realizado em Novembro e Dezembro do mesmo ano.

Elenco: Actores - Christopher Plummer (Édipo), Lilli Palmer (Jocasta), Richard Johnson (Creonte), Orson Welles (Tirésias), Cyril Cusack (Mensageiro), Roger Livesey (Pastor), Donald Sutherland (Corifeu), Frederick Ledebur (Laio), Dimos Starenios (Sacerdote), Alexis Mann (Oficial), Oenone Luke (Antígona), Cressida Luke (Ismena), Minos Argyrakis, George Dialegmenos, Takis Emmanuel, Alexandros Maniatakis, George Oekonomou, Pan Panagiotopoulos, Nicos Paschalides, Paul Roche, Achilleas Scordilis, Grigoris Stefanides, Costas Themos, George Zaifidis (membros do coro), Jenny Damianopoulou, Diana J. Reed, Mary Xenoudaki; Argumento - Michael Luke, Philip Savile, baseado na peça de Sófocles, traduzida por Paul Roche; Fotografia - Walter Lassally; Montagem - Paul Davies; Direç̧ão Artística - Yannis Migadis; Música original - Jani Christou; Guarda-Roupa - Theoni V. Aldredge, Denny Vachlioti; Som Nick Despotidis; Câmara - A. Karides Fuchs; Caracterização - Ron Berkeley; Produtor Associado - Timothy Burrill; Produtor Executivo George Saris. 


\section{Sófocles, Rei Édipo}

Produção: Teatramus - Núcleo de Teatro do Secundário do Colégio de Nossa Senhora da Apresentação de Calvão

Encenação: Filipe Jorge, Jorge Carvalhais

Tradução: Maria do Céu Fialho

$1^{\mathrm{a}}$ Apresentação: Colégio de Nossa Senhora da Apresentação de Calvão

Data: 2. 5. 2003.

Outras: Covilhã, 11. 4. 2003; Aveiro, 30. 4. 2003; Vagos, 5, 22. 5. 2003; Conimbriga, 6. 5. 2003.

Para os encenadores (e também actores), professores Filipe Jorge e Jorge Carvalhais, o desafio de apresentar um texto com a forte carga simbólica e emotiva como o do Rei Édipo de Sófocles constituiu uma enorme responsabilidade. Secundados entusiasticamente pelos professores de Latim e de Grego do Colégio, quiseram recriar este clássico sofocliano. A estreia ocorreu 'em casa', na noite do dia 2 de Maio de 2003. Estiveram presentes cerca de duas centenas de pessoas. Servindo-se de um elenco de dezanove elementos, todos eles alunos do Colégio, e estudantes dos Agrupamentos 1, 2, e 4, com indumentárias e cenários inteiramente criados para o efeito, o espectáculo decorreu, como pensado e desejado, ao ar livre, em noite primaveril.

Elenco: Actores - Carlos Carvalhais (Édipo), Simone Miranda (Jocasta), Jorge Carvalhais (Creonte), Filipe Jorge (Tirésias), Sara Leigo (Sacerdote), Bianca Barros (Mensageiro de Corinto), Janette Ferreira (Mensageiro do Palácio), Rosa Pequeno (Servo), Pedro Reis (Soldado), Daniela Simões (Antígona), Michelle Rita (Isménia); Coro - Carina Alves, Susana Diamantino, Ana Oliveira, Ana Cláudia Cruz, Neide Almeida, Lúcia Silva, Márcia Balseiro; Cenografia - Carlos Jesus, Alunos do Agrupamento 2; Guarda-Roupa - D. Rosa; Iluminação - Paulo Henrique, Pedro Neto; Composição Musical - Paulo Henrique, Pedro Neto, Fernando Ferreira.

Mário Paulo Martins

\section{Sófocles, Edipo Rey}

Produção: Teatro Corsario Encenação: Fernando Urdiales Iniciativa: XXVII FITEI

$1^{\text {a }}$ Apresentação: Porto, Rivoli Teatro Municipal

Data: 1 - 2. 6. 2004.

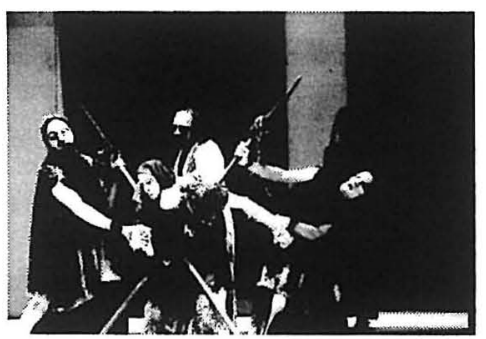

A representação do Rei Édipo que a Companhia Corsario de Valladolid trouxe ao XXVII FITEI pode considerar-se plasticamente bem 
conseguida. A encenação pretensamente clássica contém, no entanto, algumas notas dissonantes.

Tanto o cenário como o guarda-roupa (mau grado o uso anacrónico do alto coturno helenístico), evocam a tragédia grega clássica e tornam o espectáculo agradável não só à vista mas também ao ouvido, para o que muito contribui a música preponderantemente de percussão. $\mathrm{O}$ número de coreutas reduzido e variável, segundo uma estratégia de utilização dos actores disponíveis, é, por vezes, engenhosamente duplicado com o recurso a "bonecos" (cf. a ficha técnica) de estatura humana - aliás eximiamente manipulados - o que bem se compreende numa companhia que também se dedica ao teatro de marionetas. Este coro, conquanto bem sincronizado, quer quanto à locução, quer quanto aos movimentos, em nada se assemelha, todavia, a um grupo de anciãos, pois nele predominam as vozes femininas.

Pareceu-nos abusiva e inestética a introdução de determinados elementos estranhos à tragédia grega, folclóricos e dispensáveis, como os enormes leques manchados de vermelho que Édipo, Creonte e o Coro utilizam como armas, brandindo-os com hostilidade, ou a cabaça de romeiro que o Coríntio traz a tiracolo. Consideramos, no entanto, de inegável beleza a inesperada intervenção de duas figuras femininas exuberantemente vestidas de aves de rapina que, com amplos movimentos das suas asas de grande envergadura, revoluteiam no palco, quais Harpias, soltando arrepiantes pios agoirentos nos momentos cruciais da tragédia, substituindo mesmo, como portadoras de más novas, o mensageiro do palácio.

O espectáculo é servido por bons actores, devendo ser feita especial menção àquele que desempenha o papel de Tirésias.

Elenco: Actores - Pedro Vergara, Rosa Manzano, Jesús Peña, Francisco González, Miguel Bocos, Javier Semprún, Beatriz Alcalde, Cármen Gañán, Luís Miguel Garcia; Cenografia - Fernando Urdiales; Assistente de Direç̧ão - Javier Juárez; Realização Cenográfica - Juan de la Fuente; Figurinos - Olga Mansilla, Fernando Urdiales; Máscaras e Bonecos - Teresa Lázaro, Jesús Peña; Maquinistas - Manuel Alonso, Teresa Lázaro; Iluminação - Juan Carlos Andrés; Música - Juan Carlos Martin.

Ana Paula Quintela Sottomayor

Armando Nascimento Rosa, Um Édipo Encenação: Miguel Loureiro

$1^{\text {a }}$ Apresentação: Lisboa, Teatro da Comuna

Data: 6-26. 7. 2003

Outras: Évora (Teatro Garcia de Resende), 16. 1. 2004.

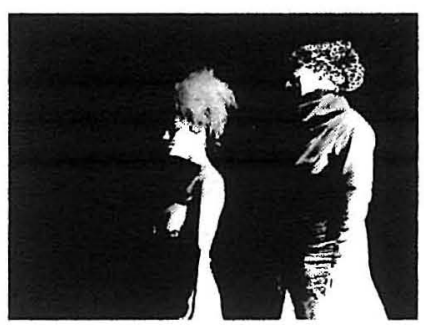


Numa tentativa de responder à famosa pergunta 'Porque nasceu Édipo amaldiçoado?', A. Nascimento Rosa reescreveu a tragédia do senhor de Tebas e reavaliou o crime sexual de Laio. As linhas principais do propósito do autor desta reescrita espelham-se do subtítulo dado ao texto: 'Mitodrama fantasmático em um acto'. Como também são patentes os seus propósitos confessos, filtrando o tema pela visão freudiana do mito: 'Interessou-me antes de mais explorar o núcleo recalcado do enredo que deu à luz o mais célebre dos complexos psicomíticos'. No plano dramático, o autor recuperou o episódio do encontro sexual entre Laio e Crisipo e fracturou as personagens em dois grupos de simbologia antagónica: Jocasta, Crisipo e Laio como representantes da morte, Tirésias, Manto e Édipo como figuras de vida. Quanto ao complexo valorizado, a opção do autor foi não para Édipo, mas para o 'complexo de Laio', segundo o qual o parricídio do rei de Tebas tem por objectivo principal punir a homossexualidade paterna. Por esta preferência, Édipo deixa de ocupar o centro da acção, para dar lugar à actuação de todos os outros agentes da acção que afinal constroem o mundo que cerca o herói e lhe justifica os actos.

Um cenário despojado, de fundo branco, apenas cruzado de uma plataforma sobre a qual as figuras se movimentam em estudada proximidade com o público, é a folha onde se escreve uma nova interpretação do velho mito. À tragédia é conferido um tom satírico, que lhe advém sobretudo do grotesco das figuras. Permito-me, à laia de conclusão, transcrever o comentário com que Ana Pais, no Expresso de 19. 7. 2003, documentava alguns pormenores de cena: 'No espaço cénico deparamo-nos com um caminho de mármore (ironicamente feito de esferovite), um painel de folhas verdes algo 'kitsch' ao centro e, ao fundo, duas portas de cada lado iluminando os bastidores. Minimal, o espaço cede a cor aos figurinos e à maquilhagem dos actores, de clara inspiração num dos géneros mais versáteis, em ritmo e cores, do teatro tradicional japonês, o Kabuki. Jocasta surge de quimono (em materiais pobres, na variante de 'trazer por casa') e fortemente maquilhada. Os figurinos dos homens, que já nada têm a ver com o Kabuki a não ser a maquilhagem, resultam numa mescla de saias compridas, sapatos de salto alto e adornos 'kitsch' ou de uma enorme cabeleira vermelha, como na personagem feminina Manto. Seguindo um registo de interpretação associado aos estereótipos japoneses, Maria Duarte, exímia no implícito tom paródico, exagera a artificialidade desse estilo e da tutelar declamação ocidental'.

Elenco: Actores - Álvaro Correia (Tirésias, Laio), Gonçalo Ferreira de Almeida (Voz de Pélops, Édipo), Maria Duarte (Jocasta), Maria João Falcão (Argena, Manto), Martim Pedroso (Crisipo); Cenário - Nuno Tomaz; Luzes - Daniel Worm d'Assumpção; Figurinos - Maria Duarte, António Filipe. 


\section{TRAQUÍNIAS}

Sófocles, Traquínias

Produção: Thíasos do IEC

Encenação: Delfim F. Leão

Direcção de actores: Victor Torres

Coreografia: Carla Braz

Tradução: Maria do Céu G. Z. Fialho

$1^{\text {a }}$ Apresentação: Coimbra, Colégio de S. Teotónio

Data: 28. 4. 2003

Outras: cerca de duas dezenas, durante os Festivais de Teatro de Tema Clássico, temporadas de 2003/4 (Figueira da Foz, Miranda do Corvo, Braga, Alcobaça, S. Martinho de Tibães, Museu de Odrinhas/Sintra, Viseu); e ainda dois espectáculos no estrangeiro: França (Tours, 3. 3. 2004) e Espanha (Cádis, 23. 7. 2004).

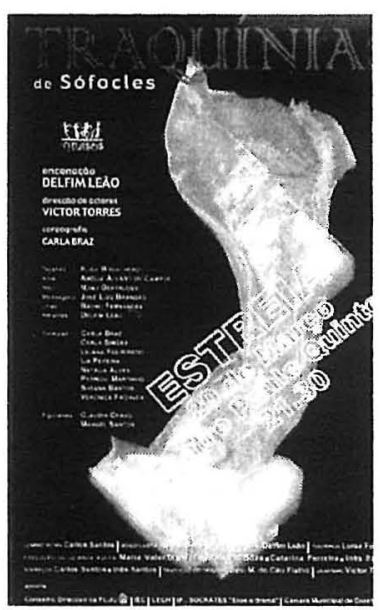

Com esta produção, o Thíasos ensaia, pela segunda vez, os caminhos da tragédia grega. Como linha orientadora da encenação, foi adoptada a imagem do fogo, enquanto metáfora da paixão que avassala as personagens centrais (Dejanira e Héracles) e também como símbolo da própria destruição que se abaterá sobre o herói dos doze trabalhos (primeiro no manto oferecido por Dejanira e, finalmente, na pira final).

A ambivalência deste poderoso signo marca a própria caracterização do coro, cujo vestuário procura sugerir as cores instáveis do fogo. De resto, ao coro cabe a função de narrar e sublinhar (com menos texto e mais recurso à música e à coreografia) parte do drama que será vivido pelo par Dejanira/Héracles. Desta forma, é o coro quem verdadeiramente inicia a peça, através de uma dança que procura sugerir a ideia de uma relação amorosa que se vai construindo através do cruzamento de passos e de gestos, até que se instala a sombra da separação. Só quando o coro se anula (como se todos os seus elementos fossem estátuas de um jardim) é que entra Dejanira, expondo à ama as apreensões que traz na alma.

Toda a movimentação do coro visa obedecer ao objectivo de fornecer um subtexto capaz de criar no espectador vários níveis de leitura. Por esse motivo, as posições assumidas procuram evocar motivos da escultura grega (as Cariátides, a Vitória de Samotrácia, o friso de um templo), numa metamorfose constante que serve ora de comentário ora de 
reforço à linha de acção. $O$ mesmo objectivo se pretende com os apontamentos de cenário (oito blocos quadrangulares), que funcionam como bases de estátuas, bancos de juízes ou ainda como a lenha da pira que há-de evocar a imolação de Héracles, na cena final, em que os mantos e as próprias jovens de Tráquis se transformam no fogo que devora o herói grego, até se debulharem no chão, como cinza ainda quente.

A aposta forte na música e em evoluções coreográficas, que aparece agora, e pela primeira vez, como uma das opções de fundo numa encenação do Thíasos, procura ir ao encontro de uma concepção do teatro grego enquanto forma de arte que vive muito da palavra, mas também da música, do canto e da dança.

Elenco: Actores - Elisa Bogalheiro/Patrícia Santos (Dejanira), Maria Amélia Álvaro de Campos/Sofia Costa/Natália Alves (Ama), Nuno Gertrudes (Hilo), José Luís Brandão (Mensageiro), Bruno Fernandes (Licas), Delfim Leão / Luís Cruz (Héracles), Manuel Santos, Joaquim da Silva (Figurantes); Coro - Carla Braz, Carla Simões, Carla Marques, Liliana Dias, Liliana Figueiredo, Lia Nunes, Natália Alves, Patrícia Ferreira, Sílvia Costa, Sónia Santos, Susana Bastos, Verónica Fachada; Guarda-Roupa - Luísa Ferreira, com a colaboração de Maria Valente e Inês Santos; Sonoplastia e Iluminação - Carlos Santos, Isidro Alves, Carlos de Jesus.

D. F. Leão 
(Página deixada propositadamente em branco) 


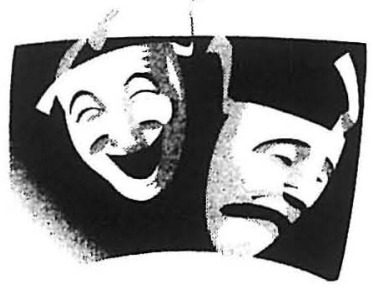

EURIIPIDES 
(Página deixada propositadamente em branco) 


\section{ANDRÓMACA}

Le Poème Harmonique (Recital com textos de Jean Racine, extraídos de Andromaque, Phèdre, Les Plaideurs, Bérénice)

Produção : Vincent Dumestre, Claire Lefilliâtre

Iniciativa : V Festival de Música de Mafra

$1^{\mathrm{a}}$ Apresentação: Mafra, Palácio Nacional (Sala do Trono)

Data: 3. 11. 2001.

Le Poème Harmonique é um grupo de executantes de música barroca, criado e dirigido por Vincent Dumestre. Mais do que um projecto musical, é um conceito, assente na noção de que a música do século XVII é algo inseparável da palavra e do discurso teatral. Assim, para além da música, a execução do canto não deve ser apenas uma exposição de virtuosismo vocal, mas uma forma de eloquência e de valorização das palavras e do discurso. Do mesmo modo, podem e devem as peças musicais ser acompanhadas, de forma harmoniosa, pela declamação de textos adequados à época. Esta noção de que a música, as palavras e o ritmo são inseparáveis não é, obviamente, estranha para todos aqueles que têm alguma familiaridade com o teatro da antiguidade clássica.

$\mathrm{O}$ recital apresentado por Le Poème Harmonique no Festival de Música de Mafra, com a participação da soprano Claire Lefilliâtre, continuou a explorar - no seguimento de obras anteriores do mesmo grupo - essa profunda ligação entre a palavra falada e a música da época barroca, desta feita através de extractos de algumas das mais marcantes obras dramáticas de Jean Racine. Nesta circunstância, mais do que na temática das peças, o interesse de Dumestre ter-se-á centrado, acima de tudo, na riqueza rítmica das palavras do dramaturgo francês.

Jorge Deserto

\section{BACANTES}

\section{Eurípides, As Bacantes}

Produção: Andrea Furtado

Encenação: Nádia Almeida

$1^{a}$ Apresentação: Lisboa, Palco Oriental (Beato)

Data: 12. 4. 2002

Outras: Lisboa (Palco Oriental), 13, 19, 20. 4. 2002;

Lisboa (Liceu Camões), 26-27. 4, 3, 4, 10, 11, 17, 18. 5. 2002; Lisboa (Mostra TE - $4^{\text {a }}$ Mostra de Teatro Jovem de Lisboa, Teatro Taborda), 13. 11. 2002

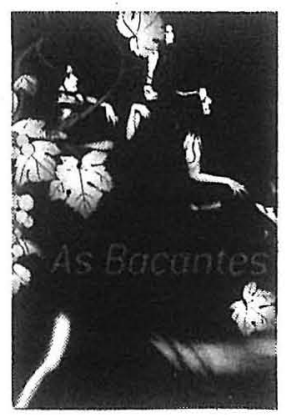


Trabalho de um grupo de teatro escolar exclusivamente dedicado à dramaturgia clássica, conforme se percebe de imediato pelo nome Grupo de Teatro Clássico Anankê, As Bacantes de Eurípides constituíram a opção estética da produção do ano de 2002. A escassa informação de que dispusemos para redigir a notícia desta realização, encontrámo-la no programa do espectáculo. Para além dos dados relativos à ficha técnica, o desdobrável contém, como se impunha, um brevíssimo resumo do conteúdo da tragédia, e os comentários da responsável pela produção, Andrea Furtado. Inserimos de seguida a citação destas últimas palavras, nas quais se colhe $o$ testemunho do feito maior que encerra a arte para quem a produz, ser em simultâneo resultado e promessa de criação: 'As Bacantes representam para o GTCA um percurso em grupo e ao mesmo tempo um percurso a solo, um meio daquilo que já fizemos, com quem crescemos ... e um princípio daquilo que faremos. Porque há uma magia que nos move e que nos marca, haverá sempre a tal partilha que nos uniu ... a nós e àqueles que para sempre do 'nós' farão parte'. Atrevemo-nos a rematar com a dedução de que o dramaturgo grego do séc. V a. C., Eurípides, através das suas Bacantes, como de outras peças, faz por certo parte desse 'nós' cultural que nos forma.

Elenco: Coro de Bacantes - Andrea Furtado, Catarina Santos, Daniela Pires, Filipa Lopes, Inês Teixeira, Nádia Almeida, Rita Cândido; Actores - Paulo Abreu (Penteu), Inês Ferreira (Harmonia), Sara d'Andrade (Agave), David Manso (Dioniso); Luzes e Som - Inês Ferreira, David Manso; Cenários e Guarda-Roupa - Grupo de Teatro Clássico Anankê; Adaptação do Texto e Coreografia - Nádia Almeida.

Carmen Soares

Caryl Churchill, Uma boca cheia de pássaroŝ

Produção: TUTRA (Teatro

Universitário de Trás-os-Montes e

Alto Douro)

Encenação: TUTRA

$1^{a}$ Apresentação: Teatro Municipal de

Vila Real

Data: 19. 4. 2004

Outras: Viseu, 27. 4. 2004; FATAL

2004- $5^{\circ}$ Festival Anual de Teatro

Académico de Lisboa, 29. 5. 2004.

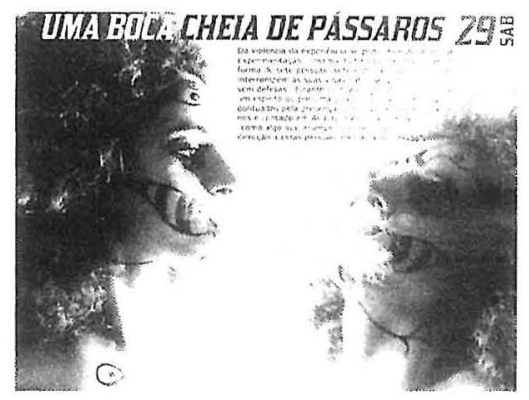


O «dia sem defesas» de Churchill, escolhido pelo Teatro Universitário da UTAD, entronca directamente nas Bacantes de Eurípides, pelo que merece ser citado como uma peça de temática clássica e figurar ao lado das que, na edição do FATAL de 2004, se dedicaram à Cultura Clássica. No caso em concreto, as personagens desta peça são possuídas por uma «mania» báquica, a partir da qual se manifesta o carácter dionisíaco e caótico de cada um. O texto organiza-se em sete cenas, com sete protagonistas, os mesmos que serão possuídos pela loucura dionisíaca, sendo essa possessão entendida como um processo de catarse fundamental para o bem-estar do ser humano.

Esta encenação acentuou o contraste entre o quotidiano das personagens, contemporâneo, com o momento da possessão, encenado em torno de um ambiente grego, onde a cor vermelha é alusiva às figuras de alguma da cerâmica helénica, como se fossem instantâneos apanhados nessa expressão artística. Por oposição, o quotidiano, como que algo despojado de emoção, é contextualizado num cenário desprovido de cor, composto de uma forma minimalista, à base do preto e azul, sobre fundo branco. A luz é o elemento essencial nesta concepção cenográfica.

Elenco: Actores - Ana M., Carmen, David, Dinho, Itziar, Joaninha, Joana S., Luís, Paula, Pedro, Raquel, Rui, Sérgio, Susana P., Susana R., Tiago, Vanda; Coreografia - Antónia Alves; Cenografia - Ana M., Miguel, Tiago; Téenicos de Luz, Som e Video - Pedro Carvalho, Dionísio, Manel e Brandinho; Design Gráfico - Ana M.; Video - Brandinho, Dionísio, Luís e Tiago; Figurinos - TUTRA; Fotografia - Manel; Direcção de Cena - Ana R. e Cláudia.

Nuno S. Rodrigues

\section{ELECTRA}

\section{Eurípides, Electra}

Produção: Michael Cacoyannis

Data da Produção: 1962

Direcção Cinematográfica: Michael Cacoyannis $1^{\text {a }}$ Apresentação: Cinema Quarteto, 22 .9. 1976

Outras: Iniciativa do Colóquio 2500 Anos, Sófocles/Cinemateca PortuguesaMuseu do Cinema, 3 . 12. 2003.

Esta produção cinematográfica da Electra de Eurípides, que teve a sua estreia mundial na edição de 1962 do festival de Cannes, integra-se numa trilogia de Michael Cacoyannis, de que também fazem parte As Troianas 
(1971, igualmente exibido em Portugal e onde brilham Katharine Hepburn, Geneviève Bujold, Vanessa Redgrave e Irene Papas) e Ifigénia (1976). Denominador comum aos três filmes foi a actuação de uma magnífica Irene Papas, que aqui se consagrou como a mais trágica das actrizes. Sendo neste filme «Electra», Papas foi a «Helena» de As Troianas e "Clitemnestra» em Ifigénia.

O que melhor define esta encenação de Cacoyannis é a proximidade que pretende manter, e que consegue, com a tragédia euripidiana. A unidade espacial faz da Electra camponesa o ponto a partir do qual o espectador assiste ao desenrolar de toda a história. A contenção, a serenidade e a obstinação de Papas são o ponto forte da construção da tragédia. Mas o desempenho de Aleka Katselli, como Clitemnestra, não fica de modo algum secundarizado. Ao trabalho das duas actrizes junta-se a fotografia, a preto e branco, que concretiza a atmosfera trágica pelo contraste luz-sombra, bem como o despojamento cenográfico, que aposta sobretudo nos planos de uma Grécia árida e montanhosa, quase sem esperança. Assim como a vida de Electra e Orestes, depois de vingados. Também o coro de mulheres gregas, trajando o negro mediterrâneo, contribui para esse efeito. Na verdade, esta Electra é o exemplo de como o teatro e o cinema se podem aliar e a cena do assassínio de Clitemnestra prova como tal aliança pode ser bastante positiva e até desejável.

Outro ponto alto desta produção é a música, da autoria de $\mathrm{M}$. Theodorakis, com quem Cacoyannis trabalhou em outras realizações, nomeadamente em Zorba.

Raro e difícil de ser visto, este filme foi exibido na Cinemateca Portuguesa no âmbito das comemorações dos 2500 anos de Sófocles, resultado de uma acção conjunta dos Centros de Estudos Clássicos das Faculdades de Letras das Universidades de Lisboa e Coimbra e da Cinemateca. Foi realmente uma oportunidade quase única a que muito poucos privilegiados desejaram associar-se. Apesar de inserido nas comemorações de Sófocles, o filme de Cacoyannis baseia-se no texto de Eurípides.

Elenco: Actores- Irene Papas (Electra), Yannis Fertis (Orestes), Aleka Katselli (Clitemnestra), Theano Ioannidou (Corifeu), Notis Peryalis (Marido de Electra), Takis Emmanuel (Pílades), Phoebus Rhazis (Egisto), Manus Katrakis (Tutor), Eleni Karpeta, Kitty Aeseni, Eleni Marinou, Anna Stavridou, Eleni Marki, Elli Trigonopoulou, Rota Logapoulou; Argumento Michael Cacoyannis, baseado na tragédia de Eurípides; Fotografia - Walter Lassally; Direcção Artística e Figurinos - Spyros Vassiliou; Música- Mikis Theodorakis; Sonoplastia - Mikes Damalas. 
Eurípides, Electra

Produção: Grupo Sardiña, do IES Elpiña,

Corunha

Encenação: Beatriz Martín e J. Ricardo Martín

Iniciativa: FESTEA, integrado no III Festival

Escolar de Teatro de Tema Clássico

$1^{a}$ Apresentação: Conimbriga

Data: 3. 5. 2002.

Assassinado Agamémnon por

Clitemnestra e seu amante Egisto, seu filho Orestes, ainda criança, teve de fugir para o exílio e sua filha Electra foi desterrada para os confins do reino, casada com um lavrador, já idoso, para

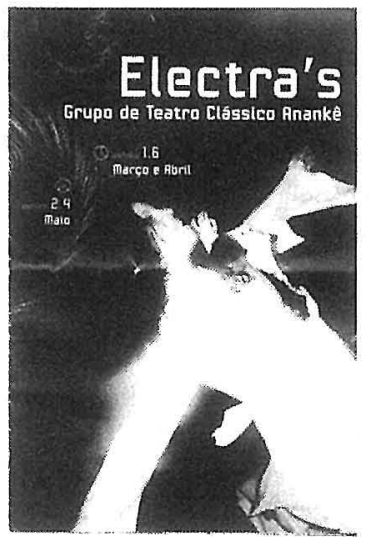
evitar uma descendência que possa vingar a morte do rei. Embora a princesa chore a sua desgraça, alimenta a esperança de que o irmão regresse e castigue os culpados. De facto assim acontece. E, no plano de vingança, Electra desempenha o principal papel.

Em Eurípides, Electra é fria, calculista; tece ela própria a teia do assassínio de Egisto e da mãe, ainda que tenha de dobrar a vontade do irmão.

Elenco: Actores - Lucía Regueiro (Electra), Alfonso R. Molares (Lavrador), José Luís López (Orestes), Mário López (Ancião); Coro - Marta Ramos, Alba Gómez, Cira Sánchez, Noemi Pallas, Sónia Candal, Iria Veigela, Tâmara Cotelo, Vanessa Pérez, Yolanda Espasandín, Tâmara Sánchez, Tâmara Canosa (Corifeu). Luzes - Iria Catoira; Banda Sonora Original - Alfonso R. Molares; Som - Vanessa Gómez; Coreografia e Vestuário - trabalho de grupo.

José Ribeiro Ferreira

\section{HERACLIDAS}

Eurípides, Heraclidas

Produção: Thíasos

Encenação e Adaptação: Delfimm

Ferreira Leão

Tradução: Cláudia Cravo

$1^{a}$ Apresentação: Conimbriga

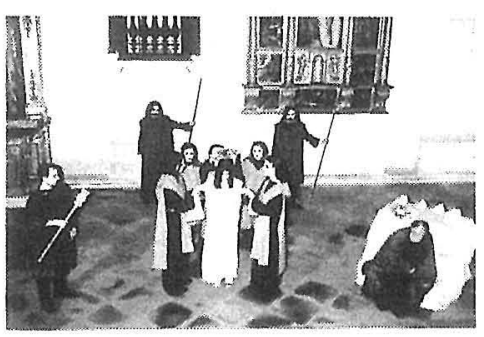


Data: 23. 4. 2001

Outras: Coimbra (Museu Nacional Machado de Castro), 24. 4. 2001; Madrid, Segóbriga, 30. 4. 2001; Conimbriga, 18. 5. 2001; Pádua (Itália) - XVI Rassegna Internazionale del Teatro Classico Antico, 27. 5. 2001; Coimbra (Claustros de Santa Cruz), 31. 5. 2001; Paços de Ferreira (Citânia de Sanfins), 1. 6. 2001; Viseu (Claustro da Sé), 9. 6. 2001; Braga (Termas Romanas), 1. 7. 2001; Parque Arqueológico do Vale do Côa, 14-15. 7. 2001; Tomar (Convento de Cristo), 20. 10. 2001; Foz Côa, 21. 4. 2002; Sintra (Museu de Odrinhas), 15. 5. 2002.

Depois de Carlos Alberto Louro Fonseca ter encenado parte de $O$ soldado fanfarrão, de Plauto, que foi apresentada no colóquio $O$ amor desde a antiguidade clássica (FLUC, 1992); de Delfim Ferreira Leão, em 1996, ter dirigido a rodagem de As mulheres no Parlamento em Conimbriga; de José Luís Brandão ter encenado o Auto da Alma, de Gil Vicente, que foi apresentado na Igreja de São João de Almedina (Coimbra) e em Lamego; e de Paulo Sérgio Ferreira ter encenado Epídico, de Plauto, que foi levado à cena dezasseis vezes entre 1999 e 2000; Delfim Ferreira Leão, que iniciou a preparação de Heraclidas em 2000, posteriormente afirmou: «O desafio colocado ao Thíasos era, assim, duplo: mudar o registo teatral e tentar fazer com que a peça Heraclidas, olhada geralmente com reserva pelos estudiosos, se tornasse num espectáculo interessante para um público moderno.» (D. F. Leão, "Thíasos - Grupo de Teatro do Instituto de Estudos Clássicos: Temporada de 2001," BEC 35, 2001, 173-6, esp. 173). Para o primeiro propósito, contou o encenador com a preciosa colaboração de Victor Torres, na direcção de actores.

À semelhança do que sucedia nas produções dos grupos escolares espanhóis, também o palco dos Heraclidas tinha muito poucos adereços: apenas uns estrados, cobertos com um tecido escuro e descaídos para a direita do espectador, que representavam os degraus do altar de Zeus em Maratona.

O coro de anciãos de Maratona, depois do diálogo inicial entre Iolau (Victor Torres) e o Arauto (Delfim Leão), entrava em palco a repetir o "evoé" báquico e com o Corifeu (Rui Henriques) a proferir, em voz cava, as primeiras palavras em grego. A imagem era impressionante, pois cada membro do coro aparecia com uma longa túnica castanha, uma espécie de opa, estreita e comprida, e um capuz, que apenas deixava ver a máscara que, com uma das mãos, segurava, para esconder a cara, enquanto, com a outra, se apoiava num longo bastão. Embora as roupas do coro nos possam sugerir as de frades e monges, a verdade é que conferem aos anciãos de Maratona a imponência adequada. Nos momentos em que o coro retirava as máscaras, viam-se rostos pintados de branco e, à volta dos olhos, de preto.

Após o segundo episódio, de teor profundamente patético e onde Macária (Alessandra Oliveira) se apresenta como a vítima a sacrificar à Filha de Deméter, segue-se o terceiro (vv. 630-747), que visa aliviar o entrecho da 
tensão anterior e, nessa medida, percorre a estreita linha que separa o sério do cómico. O Servo (Marco Terras) vem da parte de Hilo e traz boas notícias: o senhor tinha chegado com grande contingente de aliados e posicionara-se na ala esquerda do exército ateniense. Quando o Servo se prepara para regressar ao campo de batalha, Iolau anuncia que irá com ele. A cena é dramaturgicamente delicada, pois o velho socorre-se do vigor físico que the resta para refutar as objecções levantadas pelos que o rodeiam. Victor Torres e Marco Terras conseguiram um equilíbrio muito bom entre a esperada sisudez de uma tragédia e esta cena que roça o cómico, deixando no público um levíssimo sorriso.

Valerá a pena destacar o notável desempenho do experiente Victor Torres, no papel de Iolau: foi muito convincente quando enfrentou o Arauto, quando suplicou a Demofonte pelos Heraclidas, quando se resignou perante a decisão de Macária e quando se superou a si próprio e se elevou acima das expectativas das restantes personagens e do próprio público.

O balanço desta primeira incursão do Thíasos pela tragédia é, em suma, bem positivo e, por isso, o segundo objectivo enunciado pelo encenador também foi alcançado.

Em jeito de apêndice, convém realçar o facto de muitos espectáculos do Thíasos se terem integrado no II Festival Escolar de Teatro de Tema Clássico (2001), nos III Encontros de Verão de Teatro de Tema Clássico (2001), e no III Festival Escolar de Teatro de Tema Clássico (abril-maio de 2002), iniciativas que se devem saudar, porquanto criam nos jovens o gosto pelo teatro e contribuem decisivamente para a divulgação dos estudos clássicos.

Elenco: Actores - Alessandra Oliveira (Macária), Ana Rita Miranda (Alcmena), Victor Torres (Iolau), Delfim Leão (Arauto de Euristeu), Marco Terras (Servo de Hilo), José Luís Brandão (Demofonte), Paulo Sérgio Ferreira (Mensageiro), João Paulo Correia (Euristeu), Carla Braz, Cláudia Cravo, Filipe Cravo, Jordana Costa, Liliana Pena, Manuel dos Santos, Ramiro Costa, Sandra Costa, Sílvia Costa, Sónia Freitas, Susana Bastos (Coro); Direç̧ão de Actores - Victor Torres, Delfim Leão, Rui Henriques; Guarda-Roupa - Luísa Ferreira, com a colaboração de Maria Valente e Delfim Leão; Caracterização e Adereços - Ana Balula, com a colaboração de Raquel Gafanha, Patrícia e José Luís Brandão; Confecção das Máscaras Eduardo Mendes, com a colaboração de Catarina Ferreira; Som - Isidro Alves; Apoio técnico - Carlos Santos. 


\section{HIPÓLITO}

Hipólito e Fedra - $1^{o}$ assalto, adaptação de Eurípides, Hipólito Produção: TUT (Teatro Universitário da Técnica)

Encenação: Jorge Listopad

$1^{\text {a }}$ Apresentação: Lisboa, Teatro da Garagem

Data: 14-15. 6. 2003.

M. F. S. S.

\section{Jean Racine, Fedra}

Encenação: Joan Ollé

Iniciativa: FTA (Festival Internacional de Teatro de Almada)

Tradução (do original francês para catalão): Modest Prats

$1^{\text {a }}$ Apresentação: Escola D. António da Costa

Data: 18. 7.2002.

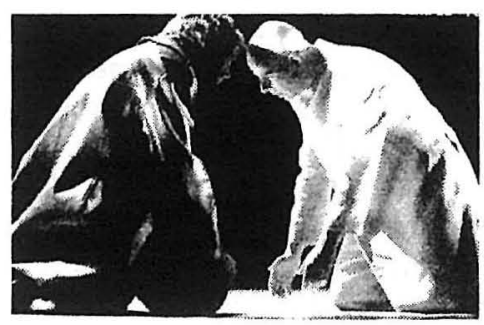

A paixão de Fedra, a forma como nela se apresenta a tensão entre a força da paixão e o silêncio que, em vão, tenta esconder, têm, ao longo dos tempos, fascinado tanto autores como encenadores teatrais.

Os espectadores do Festival de Teatro de Almada assistiram, em 2002, a mais uma leitura dos amores de Fedra, a do encenador catalão Joan Ollé, feita a partir do texto de Jean Racine.

A peça assentou numa versão catalã do texto, em versos alexandrinos - que os espectadores portugueses acompanharam com o auxílio de legendas -, da autoria do filólogo Modest Prats. O tradutor salientou, em declaraç̃os à imprensa, a extrema força e poder das palavras de Racine, que tentou salvaguardar na versão catalã. Afirmou Prats (em declarações ao diário catalão Avui, edição de 27. 7. 2002): "Não há [em Fedra] palavras inocentes, as palavras são nocivas ['nocents', no original catalão] e fazem mal."

Não surpreende, pois, que Joan Ollé tenha optado por uma encenação em que todo o destaque é dado à palavra. A movimentação foi reduzida ao mínimo e o trabalho dos actores, de rigorosíssima contenção, foi apurado com o auxílio da experiência do bailarino Andrés Corchero. Segundo Ollé, "se as personagens falam de uma forma diferente da nossa, se falam em verso, não faria sentido que se movessem e olhassem como nós; dá-se uma necessária distorção da naturalidade." (declarações ao El Cultural, suplemento do diário espanhol El Mundo, 13. 5. 2004). Do mesmo modo, 
Rosa Novell, a protagonista, sublinha: "Somos como estátuas dotadas de fala. É o texto que se move. Na frieza da contenção produz-se a faísca da emoção." (idem).

Esta aposta na economia, na busca de uma essência, "num momento em que algum teatro aposta na hiper-expressão" (Joan Ollé ao diário catalão $A v u i$, em 24. 7. 2002), parece dar os seus frutos. De acordo com o julgamento de João Carneiro, no Expresso, a "sobriedade acentua mais a genialidade da peça". Manifesta-se o poder do regresso à palavra, ainda mais marcante numa sociedade que vive saturada de efeitos e desligada do essencial.

A abordagem de Joan Ollé à Fedra de Racine teve continuidade. Estreou recentemente (em 19. 5. 2004), em Madrid, uma versão em língua castelhana desta sua leitura cénica da peça do dramaturgo francês. Nela participa a maior parte dos actores que, em 2002, vieram a Almada.

Elenco: Actores - Rosa Novell (Fedra), Eduard Farelo (Hipólito), Ángeles Poch (Ama), Pere Arquillué (Teseu), Lluís Homar, Marta Molins, Irene Montalá, Cesca Piñon.

Jorge Deserto

\section{IFIGÉNIA EM ÁULIDE}

Ch. W. Gluck, Ifigénia em Aulide (Abertura)

Iniciativa: Teatro Nacional de São Carlos / Teatro Municipal São Luiz / Câmara Municipal de Setúbal

$1^{\text {a }}$ Apresentação: Setúbal, Forum Municipal Luisa Todi

Data: 30. 9. 2003

Outras: Lisboa (Teatro Municipal São Luiz), 1. 10. 2003.

No âmbito do programa 'Cinco Pianistas Portugueses para os Cinco Concertos de Beethoven', promovido em parceria pelo Teatro Nacional de São Carlos, pelo Teatro Municipal São Luiz, em colaboração com a Câmara Municipal de Setúbal no plano das comemorações dos 250 anos do nascimento de Luisa Todi, realizou-se um concerto onde foi executada a abertura da Ifigénia em Áulide de Gluck. A execução musical coube à Orquestra Sinfónica Portuguesa do TNSC e a direcção musical ao Maestro Riccardo Frizza. Participaram ainda o pianista Artur Pizarro e a soprano Elisabete Matos.

M. F. S. S. 


\section{ÍON}

\section{Eurípides, Íon}

Produção: Grupo «Selene», do IES Carlos III, de Madrid

Iniciativa: FESTEA - Festival de Teatro de Tema Clássico

$1^{\text {a }}$ Apresentação: Coimbra, Pátio da Universidade

Data: 2. 6. 2001

Outras: Conimbriga 3. 6. 2001, 29. 6. 2002; Braga (Termas Romanas), 30. 6. 2002.

Esta peça de Eurípides está ligada às origens míticas de Atenas e do nome de Iónios.

Apolo seduzira Creúsa, filha do lendário rei de Atenas, Erecteu, e deixara-a grávida. Esta expôs o filho junto da Acrópole, escolhendo o mesmo lugar para testemunha quer da violência recebida quer do parto. Hermes recolheu o recém-nascido e levou-o a Delfos. Aí a Pítia, profetisa de Apolo, encontrou-o e criou-o. Íon, como será chamado depois, cresce e torna-se administrador do Templo. Desse modo, sem o saber, o jovem tornou-se servidor do seu pai. Quanto a Creúsa, Xuto desposa-a, já que, ao combater por Atenas como aliado, recebeu como recompensa a realeza e a mão da princesa. Mas esta não teve mais filhos. Decidem então dirigir-se a Delfos, para consultar o Oráculo de Apolo.

Aí, depois de várias peripécias em que Xuto julga ter encontrado um filho que desconhecia ter e em que Creúsa, sem resultado, planeia matar Íon, desconhecendo que era seu filho, mãe e filho conhecem as suas verdadeiras identidades e fundir-se-ão num abraço, perante o perplexo e surpreso Xuto.

A cena do drama passa-se no santuário de Delfos. Como a construção do templo de Apolo seria impraticável numa peça que se destina a ser representada ao ar livre e em locais monumentais ou arqueológicos, optaram os encenadores por dar visibilidade a «uma série de elementos do próprio santuário e de toda a liturgia délfica»: trípode sagrada, omphalos, uma coluna iónica, ramos de loureiro, a árvore sagrada do deus, e o arco e flechas, já que Apolo é o senhor do arco. Graças a estes adereços, o espaço cénico aparece configurado como um triângulo, cujos vértices são balizados pela «trípode da Pítia - vértice central» -, pelo 'omphalos' «que será aqui o altar de Apolo vértice esquerdo» - e pela «coluna iónica, alusão inequívoca à história que se representa e tributo à presença de Atena, tanto na obra como no próprio complexo délfico».

Neste cenário, em que se moveram actores e Coro, Oliver Plazas interpretou de forma excelente a figura de Íon e Rebeca Amez foi convincente e segura no papel de Creúsa. E o aparecimento de Atena, em interpretação de Laura López, na posição de "Atena Pensativa" (c. 460 a.C.) - o célebre relevo de estilo severo, período clássico - produz um belo efeito cénico. O Coro, nas suas vestes de cor verde azeitona - a sugerir, como 
elucida Gemma López, «as oliveiras milenares do vale de Crisa», nas encostas de Delfos - encheu a cena, dando-nos a cada passo, com as posições de corpo e braços, a sugestão de cariátides ou de fachada de templo, imagens bem adequadas a uma peça cuja acção se passa no Santuário de Delfos. Assim, além de sublinhar os momentos importantes da acção dramática, provoca um efeito estético no espectador. Formado por doze servas de Creúsa, o Coro - de que Virginia Oteros foi Corifeu - foi interpretado por Tania Samalea, Sara Cazorla, Letícia Flores, Eva Andrés, Carla González, Jessica Torres, Diana Curtido, Susana Cristóbal, Teresa Torres, Vanessa Méis, Letícia Valle e Yolanda Almeida.

A encenação impõe-se pelo rigor dos figurinos e pela movimentação das personagens e do Coro, qualidades a que nos habituaram Gemma López Martínez e José Luis Navarro. O rigor foi mesmo ao ponto de adequar as cores a cada personagem, como Gemma López explica: «la gama dourada foi reservada para os que vivem mais junto de Apolo, mais instalados no santuário. Os servos aparecem vestidos em tons escuros, Creúsa utiliza uns tons malva mais distintos. Xuto leva também cores escuras»».

A iluminação e o som estiveram a cardo de Carlos Guitart e Miguel Ángel Pérez; a cenografia pertenceu a TRAGACANTO.

José Ribeiro Ferreira

\section{MEDEIA}

\section{Eurípides, Medeia}

Produção: DireitoàCena - Grupo de Teatro da Faculdade de Direito da Universidade do Porto (FDUP)

Iniciativa: DireitoàCena

Encenação: Roberto Merino

Tradução: Maria Helena da Rocha Pereira

$1^{a}$ Apresentação: Teatro Latino (Porto)

Data: 6 .12. 2001

Reposições: 7 e 8 de Dezembro (Teatro Latino, Porto) e ainda 22 de Maio de 2002, no T.Zero.Com, Porto, no âmbito do "Pó de Palco I Festival de Teatro Universitário do Porto".

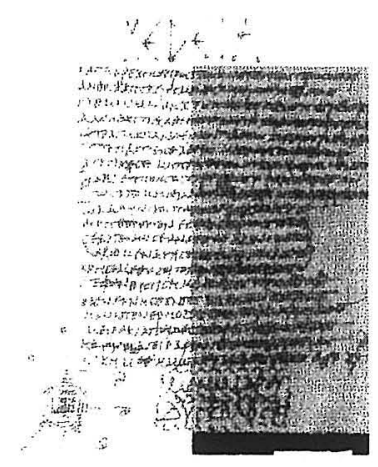

O DireitoàCena - Grupo de Teatro da Faculdade de Direito da Universidade do Porto foi criado em 2000. Entre os seus objectivos conta-se, sobretudo, a preocupação de formar um público de teatro e para o teatro, de descentralizar a actividade dramática (procurando vencer as barreiras que se 
colocam ao teatro amador) e de contribuir ainda para a construção de uma ideia de comunidade universitária mais integrada e mais madura. A Medeia de Eurípides é o segundo trabalho do grupo, num total de quatro produções apresentadas já pelo DireitoàCena.

Elenco: Actores - Alfredo Martins, Anabela Leão, António Matos, Cláudia Linhares, Filipe Gaspar, Joana Carneiro, Luísa Ferreira, Luísa Neto, Liliana Costa, Marta Faria, Patrícia Santos, Rui Cunha, Sofia Ramalho, Tomásia Moreira; Cenografia - Telmo Castro e alunos do $2^{\circ}$ ano do Curso Superior de Arquitectura da Escola Superior de Artes do Espectáculo; Sonoplastia e Iluminação - João Fontes e Bruno Santos; Aderecistas Telmo Castro

D. F. Leão

\section{Eurípides, Medeia}

Produção: Grupo Teatral

Freamundense

Iniciativa: Associação de Socorros

Mútuos de Freamunde e Festival de

Teatro Construção (Joane)

Encenação: Ruan Fernandez

$1^{a}$ Apresentação: Associação de

Socorros Mútuos de Freamunde

Data: 21. 6. 2002

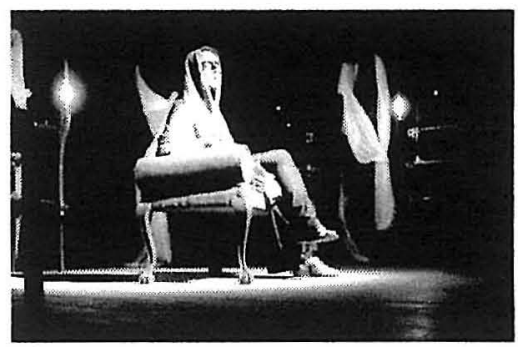

Outras: 8 de Julho (Freamunde) e Outubro de 2002 (Centro Cultural de Joane).

Terá sido a modernidade da obra euripidiana, notória em particular na forma como o dramaturgo ateniense trata a imagem da mulher, que terá levado o Grupo Teatral Freamundense a deixar-se tentar pela produção da Medeia de Eurípides. A encenação visava estabelecer uma ligação entre a realidade do séc V. a.C. e a contemporaneidade. Essa opção era visível, por exemplo, na concepção do guarda-roupa (que procurava evocar os trajes da época), em alguns elementos de caracterização (como os apontamentos de máscaras) e na presença no cenário de elementos marcadamente modernos (como acontece com os ecrãs de televisão). Assumindo embora o carácter amador da produção e do grupo, o espectáculo teve casa cheia e houve mesmo a necessidade de repô-lo, com idêntica adesão do público.

O mesmo espectáculo foi retomado, em Outubro, para uma das edições do "Festival de Teatro Construção", cuja origem remonta já a 1978. Na temporada de 2002 (realizada no Centro Cultural de Joane), o programa 
contemplava a Medeia euripidiana pelo GTF e ainda outra produção de tema clássico: As Troianas pelo grupo Capoeira.

Elenco: Actores - Marisa Gomes (Aia), Ricardo Machado (Preceptor), Raquel Pedra e André Machado (Crianças), Marisa Gomes (Medeia), Francisco Graça (Creonte), Ricardo Graça Leão (Jasão), Ricardo Santos (Egeu), Tiago Costa (Mensageiro), Maria do Carmo Correia (Corifeu), Ana Luísa Rodrigues, Alexandrina Pedra, Deolinda Pedra, Sílvia Ferreira, Catarina Martins, Isabel Gomes, Inês Rego (Coro); Cenografia Juan Fernandez, Nuno Leão; Sonoplastia, Iluminação e Video - Pedro Lopes, Carlos Nogueira, José António Santos; Aderecista - Fátima Moreira.

D. F. Leão

\section{TROIANAS}

\section{Eurípides, As Troianas}

Produção: Grupo «Balbo», do IES Santo Domingo, de Puerto de Santa Maria (Cádis)

Iniciativa: FESTEA, integrado no III Festival Escolar de Teatro de Tema Clássico

$1^{a}$ Apresentação: Tomar, Convento de Cristo

Data: 28. 4. 2001

Outras: Coimbra (Museu Machado de Castro), 30. 4. 2001; Braga (Termas Romanas), 6. 7. 2002.

O Grupo Balbo já tinha apresentado em Conimbriga e Coimbra esta peça (Representações de Teatro Clássico II, pp. 137), com encenação idêntica, mas com elenco de actores e com interpretações deferentes.

Percorre As Troianas de Eurípides um pensamento anti-belicista, de solidariedade, de respeito pelas pessoas, acentuado nesta encenação. Quer dizer, transmite valores psicológicos e morais. Sobretudo procura exaltar os grandes sofrimentos que viveram, como já dizia Homero, «as mulheres de belas tranças»».

Essas mulheres, viúvas ou filhas dos troianos mortos na guerra, aguardam para ver que destino as espera, quando a sua cidade está prestes a consumir-se nas chamas. Hécuba, a rainha-mãe, vai recebendo da boca do arauto grego Taltíbio as notícias do sorteio que acabam de efectuar os chefes do exército aqueu. E, a partir da primeira informação, Eurípides apresentanos uma dor que vai crescendo em intensidade e que se personifica na figura de Hécuba. Assim a anciã rainha vai saber que a sua filha Políxena será 
degolada como oferenda no túmulo de Aquiles; que Cassandra vai ser levada até Micenas, onde a aguarda a morte, que ela própria profetiza; que Andrómaca - paradoxo do destino - vai ser a companheira de leito de Neoptólemo, filho de Aquiles, o assassino de Heitor, seu legítimo marido. A dor de Hécuba atinge o paroxismo, quando Taltíbio chega de novo para levar a cabo a acção mais ignominiosa e impensável: o assassinato de Astíanax, o filho de Heitor, criança ainda, de uma forma especialmente brutal, despenhando-o das torres de Tróia. $O$ lamento da rainha diante do infortunado cadáver do neto mistura-se, no final da obra, com o estrépito dos edificios de Tróia que se desmoronam sem remédio, consumidos pelas chamas.

Esta figura, sofrida mas determinada, foi excelentemente interpretada por Eva María Rodríguez Cruz; no papel de Taltíbio esteve impecável Francisco Javier Ortega Jaén, conseguindo dar os diversos cambiantes que a missão do arauto grego implica; Patricia López Ocaña, na difícil interpretação de Cassandra, conseguiu dar o êxtase e delírio dessa figura e a passagem lenta ao estado de lucidez, bem como os ambíguos oráculos sobre o seu futuro e o de Agamémnon; a dor de Andrómaca, quer como esposa, quer como mãe, ao perder o marido e o filho ao mesmo tempo, foi bem transmitida por Esther Pumar Reyes. As outras figuras foram de modo geral bem interpretadas, sem realce especial: Menelao por Marcos Collado Martín, Helena por Elisabeth Mena Linder.

Como pano de fundo, o Coro (Elisabeth Mena Linder, Fátima Jiménez Enrique, María Serpa Mora, Regina Carballo López, Libertad Marín Rueda, María Reyes, Zoraida Valiente Rodríguez), bem guiado pela Corifeu Margarida Domínguez Sánchez, transmitiu bem o sofrimento das mulheres troianas que a conquista da cidade transformou em escravas. Esta encenação das Troianas, da responsabilidade, como outras do Grupo Balbo, de Emilio Flor Jiménez, apresentava ainda um Coro de homens que representavam os vencedores, com a sua arrogância, insolência e brutalidade.

As luzes estiveram a cargo de Joaco Arjona Cabrera e o som de Antonio Pecho Martín. A coreografia e o vestuário foram trabalho de grupo.

José Ribeiro Ferreira

\section{Eurípides/Sartre, As Troianas}

Produção: Grupo Capoeira

Encenação: Fernando Pinheiro com assistência de Sofia Oliveira e Susana Pinheiro.

Iniciativa: Festival Escolar de Teatro Construção

$1^{a}$ Apresentação: Famalicão, Centro Cultural de Joane

Data: Outubro de 2002. 
Também Sartre levou à cena a sua produção, em Paris, em Março de 1965, As Troianas - não alterando «a substância da tragédia» de Eurípides, mas apenas explicitando e actualizando alguns pontos do enredo «que seriam de difícil compreensão para o homem contemporâneo» - no decurso da guerra de Argélia, como acontecera com Eurípides que a compôs e apresentou no tempo da terrível guerra do Peloponeso (431-404 a.C.). E acentua que «tanto Eurípides, há 2.400 anos, como Sartre, há apenas 37 anos, estavam preocupados com a situação mais patética de qualquer guerra: a sorte dos não combatentes que, sem terem culpa de nada, têm de passar sofrimentos amargos, como a perda do lar, da familia, do orgulho, do país, quando não da própria vida».

Os sofrimentos e os lamentos das mulheres troianas são, afinal, os das mulheres de todos os tempos, desde que «apanhadas no torvelinho destruidor da guerra, seja em Tróia, Argélia, Timor, Afeganistão ou Médio Oriente». Assim justifica o grupo a reposição da peça de Sartre, em 2002.

As Troianas, em encenação de Fernando Pinheiro com assistência de Sofia Oliveira e Susana Pinheiro, é a segunda peça da trilogia trágica dedicada à condição feminina que, iniciada em 2001 com a apresentação de $A$ Casa de Bernarda Alba de Frederico Garcia Lorca, concluiu em 2003 com a Antígona de Sófocles, em Outubro.

Elenco: Actores - Pedro Pedro (Póseidon), Sónia Costa (Palas Atena), Luísa Reininho (Hécuba), Rosalina Ramos (Corifeu), Filipe Fonseca e Castro (Taltíbio), Sofia Oliveira (Cassandra), Susana Pinheiro (Andrómaca), Armindo Cerqueira (Menelau), Rosa América (Helena); Coro - Mariana Nogueira, Carla Cardoso, Ana Gomes, Luisa Gomes, Rosalina Ramos; Guardas - Sérgio Macedo, António Alves; Cenografia - Fernando Pinheiro apoiado por Hilário Portela; Figurinos - Armindo Cerqueira apoiado por Sofia Oliveira, Susana Pinheiro e Givec; Música - Montagem de F. Pinheiro a partir de temas interpretados por Michel Tirabosco em flauta de pã com acompanhamento à guitarra, de temas do album The Space Between Us de Craig Armstrong e "Dies Irae" do Requiem Cn D. minor K626, de Mozart; Efeitos Especiais - Fernando Pinheiro com Mário Mano Maciel; Operador Técnico de Luz e Som - Mário Mano Maciel. 
(Página deixada propositadamente em branco) 


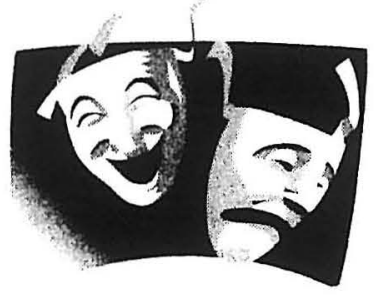

ARISTÓFANES 
(Página deixada propositadamente em branco) 


\section{LISÍSTRATA}

\section{Aristófanes, Liststrata}

Produção: Grupo Dramático de Vilar do Paraíso

Encenação e Dramaturgia: Arlete de Sousa

$1^{\text {a }}$ Apresentação: Vilar do Paraíso, Espaço do Grupo Dramático de Vilar do Paraíso

Data: 6. 7. 2001

Outras: Vilar do Paraíso, 21-23. 9. 2001; Madalena, 23. 2. 2002; Auditório Municipal de Vila Nova de Gaia, 6. 4. 2002; Gulpilhares, 27. 4. 2002; Vilar de Andorinho, 20. 9. 2002; Avintes, 2. 11. 2002; Vilar do Paraíso, 30. 11. 2002 .

O Grupo Dramático de Vilar do Paraíso escolheu para a sua $81^{\mathrm{a}}$ produção a comédia Lisístrata, de Aristófanes, com encenação e versão dramatúrgica de Arlete de Sousa.

Afirma a encenadora que nesta adaptação do conhecido tema aristofânico em que as mulheres declaram greve ao sexo para obrigarem os homens a estabelecerem a paz, "não se pretendeu defender a bandeira do feminismo (...), mas apelar para o fim de uma e qualquer guerra, seja no tempo de Aristófanes (...), seja nos dias que correm...".

$\mathrm{Na}$ simplicidade do cenário, os actores movimentaram-se exibindo vestuário sugestivo do ambiente da Grécia antiga. Destaque particular mereceu a actuação de Joana Almeida (Lisístrata).

$\mathrm{O}$ elenco de personagens apresentou algumas alterações face à comédia escrita por Aristófanes. Com efeito, dele não constam os Coros de Velhos e Velhas que figuram na peça do comediógrafo grego; surgem porém na representação duas figuras femininas mais idosas do que as jovens mulheres que se juntam a Lisístrata, amas da protagonista.

$\mathrm{O}$ tom divertido do texto, bem como a projecção na actualidade de questões tratadas por Aristófanes são, à partida, elementos propícios à adesão do público que, na reposição da peça em Avintes, manifestou com o seu aplauso o apreço pelo empenho e trabalho do Grupo de Vilar do Paraíso na representação desta comédia.

Elenco: Actores - Joana Almeida (Lisístrata), Teresa Alves e Linda Fernandes (Amas de Lisístrata), Gisela Mota (Lâmpito de Esparta), Sílvia de Oliveira (Cleonice), Mónica Pacheco (Mírrina), Ana Raquel Reis (Mulher de Esparta), Maria João Almeida (Mulher Cita/ Mulher de Atenas), Sofia Cunha (Aguadeira/ Mulher de Atenas), Marlene Pereira (Aguadeira/ Mulher de Atenas), Marta Coto (Mulher da Beócia/ Mulher de Atenas), Filipe Brito (Magistrado), Gabriel Cunha (Fogueiro/ Cidadão de Atenas), Nuno Valdemar Guedes (Cinésias/ Militar/ Embaixador de Atenas), Geoffrey Cunha (Mensageiro de Esparta/ Militar/ Embaixador de Atenas), Joaquim Guerra 
(Militar/ Embaixador de Atenas), Manuel Mota (Militar/ Embaixador de Atenas); Figurinos - Olga Rego; Desenho Cenográfico - Nuno Valdemar Guedes; Música - Gabriel Angélico; Coreografia e Movimento - Inês Rego; Cerâmica - Maria Manuel Couto Pinto; Construção de Cenários e Adereços - Joaquim Guerra, Gabriel Cunha, Nuno Valdemar Guedes e Colectivo; Operação de Luz e Som - Victor Oliveira.

Susana Hora Marques

Aristófanes, Lisístrata ou A Guerra dos Sexos

Produção: Teatro Meia Via

Encenação: Carlos Aurélio

Tradução: Manuel João Gomes

Dramaturgia: Graça P. Corrêa

$1^{\mathrm{a}}$ Apresentação: Torres Novas, Meia Via (Quinta do Casalito)

Data: Março de 2002

Outras: Torres Novas (Auditório do Museu Etnográfico), 28. 11, 5 e 12. 12. 2003.

Lisistrata ou a Guerra dos Sexos foi o

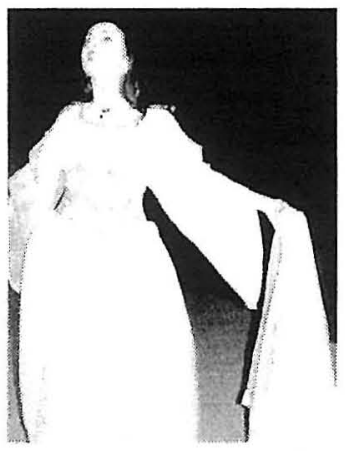
título do espectáculo que o grupo Teatro Meia Via apresentou durante os fins-de-semana do mês de Março de 2002, na Quinta do Casalito, propriedade agrícola transformada num aprazível espaço cultural, situada na Meia Via, aldeia do concelho de Torres Novas. A traduição seguida é da autoria de Manuel João Gomes e a dramaturgia da responsabilidade de Graça P. Corrêa. A encenação, o cenário e os figurinos estiveram a cargo de Carlos Aurélio, actor e encenador com créditos firmados nos palcos nacionais, que, no entanto, nunca esqueceu as suas raízes e tem sido um incansável dinamizador do teatro na sua terra. O referido grupo, fundado em 19 de Abril de 2001, é constituído por um elenco de actores amadores, cujo desempenho em palco nada fica a dever a muitos actores profissionais.

O objectivo primordial da obra, como é sabido, prende-se com o esforço de conciliar os Gregos, envolvidos numa guerra interminável. Com efeito, a peça gira em volta de uma decisão insólita de Lisístrata, personagem que instiga as outras mulheres à abstinência sexual, enquanto os seus maridos não estabelecessem a paz. O conflito suscitado, onde se destaca a incompreensão e ira dos homens, irá conduzir, depois de diversas peripécias, a um desfecho favorável a toda a comunidade: voltará o amor, porque foi celebrada a paz.

A encenação deixa, em larga medida, que o enredo aristofânico tome conta do palco, conseguindo manter o espírito do texto grego; não obstante o 
espectador menos versado na história e cultura da Antiguidade acompanha com facilidade a acção. $\mathrm{O}$ cenário do espectáculo, de extrema simplicidade, tem como elemento marcante um pórtico, evocativo da Acrópole. O guardaroupa masculino sugere o antigo mundo grego e as mulheres, pelas suas diferentes proveniências, apresentam uma indumentária diversificada e colorida, onde não falta a túnica cor de açafrão, veste feminina de eleição. No que concerne à sonoplastia, os trechos escolhidos estavam adequados à representação e eram, na sua maioria, da autoria de Mikis Theodorakis, compositor contemporâneo grego de referência.

Com efeito, é com atenção e prazer que o espectador acompanha este tema pacifista colhido no quotidiano. A conjugação de artifícios cómicos e de ambíguas insinuações de carácter sexual contribuem para a vivacidade da peça, sem nunca esquecer a forte sátira aos homens que fazem a guerra. Estão, pois, reunidos os ingredientes para que o espectáculo resulte plenamente.

As sessões esgotadas testemunham o êxito obtido, que provém, em boa parte, do aproveitamento de certas questões de ordem social e política, fundamentais na Antiguidade Clássica, projectando-se indubitavelmente na actualidade.

Elenco: Actores - Elsa Vieira (Lisistrata), Sandra Vieira (Cleonice), Liliana Domingos (Mírrina), Patrícia Domingos (Lâmpito), Marta Gabriel (Mulher da Beócia), Inês Ramos (Rapariga de Corinto), Guilhermina Constantino (Primeira Mulher), Amélia Maia (Segunda Mulher), Alice Ramos (Terceira Mulher), Carlos Domingos (Estrimodoro), António José Paz (Draces), José Ramos (Filurgo), António José Paixão (Magistrado), Daniel de Jesus (Guarda), João Serôdio (Cinésias), Alexandre do Canto (Garoto), Paulo Sousa (Mensageiro), Ricardo Teixeira (Embaixador Espartano), António Luís Graça (Polícares); Encenação, Cenário e Figurinos - Carlos Aurélio; Apoio Dramatúrgico - Graça P. Corrêa; Banda Sonora - Hugo Gama; Luz Pedro Graça, Carlos Maia; Som - Nuno Sousa; Guarda-Roupa Guilhermina Constantino.

José Manuel Ventura

\section{Aristófanes, Lisistrata}

Produção: Grupo Calatalifa (Madrid)

Iniciativa: III Festival de Teatro de Tema Clássico $1^{a}$ Apresentação: Coimbra, Museu Nacional de Machado de Castro

Data: 2. 5. 2002

Outras: Coimbra (Pátio da Universidade), 11. 7. 2002.

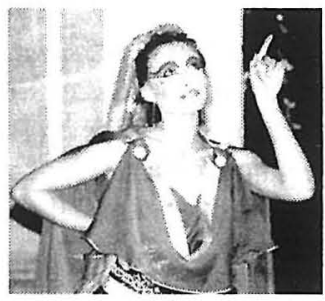

M. F. S. S 
Aristófanes, Lisístrata

Produção: A Barraca

Encenação: A Barraca

$1^{a}$ Apresentação: Lisboa, Teatro Cinearte

Data: 27. 3. 2003.

Esta apresentação da celebrizada Lisistrata de Aristófanes foi feita no âmbito do «Lysistrata Project», organizado por Kathryn Blume e Sharron Bower, duas actrizes norteamericanas. Esse projecto teve como proposta fundamental a leitura encenada da comédia de

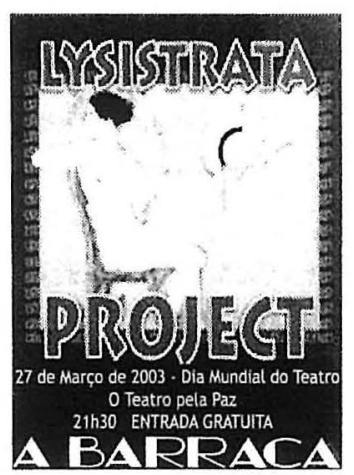
Aristófanes, por ocasião do deflagrar da guerra do Iraque, em Março de 2003. Concretizaram-se, até à data da apresentação portuguesa, feita precisamente pel' A Barraca, mais de 1033 leituras do texto aristofânico em 59 países. Deste modo, a Lisistrata da Antiguidade Clássica, também ela uma mensagem de paz num período particularmente turbulento da História da Grécia, serviu como protesto global contra as iniciativas bélicas levadas a cabo no Próximo Oriente, no alvor do século XXI.

A leitura encenada portuguesa teve lugar no dia 27 de Março, o mesmo em que se comemora o Dia Mundial do Teatro, e a entrada foi gratuita. O cartaz que acompanhou a divulgação deste espectáculo, mostrando uma mulher grega sentada, rejeitando o elmo da guerra que lhe é oferecido, parece ter sido inspirado nas figuras vermelhas da cerâmica grega e serviu de iconografia universal para o projecto.

Elenco: Actores - Maria do Céu Guerra (Coro das Velhas Mulheres), Rita Lello (Mírrina), Mafalda Franco (Mulheres), Daniela Feio (Cleonice), Mariana Abrunheiro (Lâmpito), Catarina Santana (Lisístrata), Gil Filipe (Cinésias, Lacónio), Luís Thomar (Coro dos Homens, Comissário do Povo), Jorge Sequeira (Prítane), Vítor d'Andrade (Arauto, Filho de Cinésias), Sérgio Moras (Lacónio).

Nuno S. Rodrigues

\section{Aristófanes, Lisistrata}

Produção: Academia Sénior de Vila Nova de Gaia

Encenação: Norberto Barroca

Tradução: Manuel João Gomes

$1^{a}$ Apresentação: Vila Nova de Gaia, Auditório Municipal

Data: 22. 6. 2004. 
Elenco: Actores - Maria Armandina (Lisístrata), Maria Andrelina Sousa (Cleonice), Maria Luísa Geada (Mírrina), Fernanda Fernandes (Lâmpito), Rosaria Sá (Mulher Ateniense), Eulália Mota (Mulher Ateniense), Maria Conceição Queirós (Mulher Ateniense), Margarida Amora (Mulher Ateniense), Maria Emília Geada (Mulher Ateniense), Celestina Grilo (Mulher Ateniense), Beatriz Nogueira (Mulher Ateniense), Maria Carmo Carvalho (Mulher Ateniense), Olívia Neto (Mulher Ateniense), Maria Júlia Robalo (Mulher Ateniense), Maria Graça Almeida (Mulher Ateniense), Maria Amparo Alvim (Estratílis), Ramiro Rio Novo (Magistrado), Alfredo Sousa (Polícares), Lúcio Figueira (Cinésias), Humberto Pinto (Homem Ateniense), Manuel António Silva (Mensageiro Espartano); Encenação - Norberto Barroca.

Ana Paula Quintela Sottomayor

\section{A. Boal, Mulheres de Atenas}

Produção: Alunos no Palco, Escola Secundária Aquilino Ribeiro (Oeiras)

Encenação: Ana Cristina Lúcio

$1^{\text {a }}$ Apresentação: Oeiras, Auditório Municipal Eunice Muñoz

Data: 6. 5. 2001.

Constituíram o elenco todos os alunos da Turma D do $12^{\circ}$ ano da disciplina de Trabalhos de Aplicação de Animação Social. Foram utilizadas as músicas seguintes; 'Mulheres de Atenas' de Chico Buarque de Holanda e 'Barnyard Disturbance' de Edgar Meyer.

Elenco: Actores - Susana Paiva (Lisístrata), Célia Garcia (Cleonice), Sofia Afonso (Mírrina), Ana Filipa (Lâmpito), Fátima Nunes (Jovem da Beócia), Sónia Gomes (Pequenita), Sónia Gomes (Primeira Mulher), Fátima Nunes (Segunda Mulher), Sílvia Guerreiro (Terceira Mulher), Alexandra Gonçalves (Quarta Mulher), Ana Isabel Martins (Criança), Lúcia Tomé (Escrava), Carlos Monteiro (Comissário, Corifeu, Cinésias, Ateniense), Tânia Nunes (Embaixador, Ateniense e Espartano), Patrícia Carmono (Corifeu); Coro - Tânia Nunes, Marina Lopes, Ana Mendes; Luz e Som - Técnicos da Câmara Municipal de Oeiras.

M. F. S. S. 


\section{AS MULHERES QUE CELEBRAM AS TESMOFÓRIAS}

\section{Aristófanes, As mulheres que celebram as Tesmofórias}

Produção: ECO - Grupo Amador de Teatro da Faculdade de Economia do Porto

Encenação: Tó Maia

Tradução: Maria de Fátima Silva

$1^{\mathrm{a}}$ apresentação: Jardins da Casa das Artes, Porto

Data: 20- 25 de Maio de 2003.

Numa iniciativa no âmbito do teatro universitário, um grupo "amador de teatro" - na expressão dos próprios -, composto por alunos da Faculdade de Economia do Porto, levou a efeito uma curta série de seis apresentações desta comédia de Aristófanes, que decorreu de forma algo discreta, fruto de uma promoção que não se pautou pela agressividade.

Trata-se de um grupo de teatro já com alguma consistência, pois desde 1998 mantém actividade contínua, através da apresentação pública de uma peça em cada ano lectivo. Esta foi, no entanto, a sua primeira aproximação aos clássicos greco-latinos.

Ao nível da dramaturgia, escolheu-se uma aproximação respeitadora, aproveitando a vantagem de se usar uma tradução de qualidade e que resulta muito bem quando tratada como texto dramático. Não se procurou subverter ou actualizar o texto original, antes uma aproximação à sociedade ateniense, aqui e além com pequenos sinais dissonantes ao nível dos figurinos, num contraste com resultados positivos.

O trunfo maior desta encenação foi, essencialmente, a forma como se apropriou do espaço privilegiado no qual decorria o espectáculo. Os jardins da Casa das Artes são um espaço relativamente vasto, arborizado, com um desenho de iluminação particularmente conseguido. Assim, os espectadores foram convidados a acompanhar os actores em três espaços distintos: um brevíssimo, inicial, correspondente à viagem de Eurípides e do seu Parente em direcção à casa de Ágaton; um segundo que representaria a entrada da casa de Ágaton, junto de uma escadaria, onde assistimos, por meio de um engenhoso processo de ocultação, à metamorfose do Parente; um terceiro, finalmente, junto de uma árvore particularmente frondosa $\mathrm{e}$ imponente, onde decorrem as celebrações feitas pelas mulheres de Atenas. A forma inteligente como se aproveitou o cenário natural é, possivelmente, o aspecto mais conseguido desta peça.

Sublinhe-se, também, a natural irregularidade das interpretaç̃es (ainda que num plano globalmente positivo) e a forma como, ao nível das marcações, os actores procuraram envolver o público presente e, ainda que de modo algo mitigado, interagir com ele, num procedimento que ganharia em ter sido mais explorado, seguindo um modelo que a própria comédia ateniense usou com abundância. 
Elenco: Actores - Ricardo Coelho (Eurípides), Edgar Cabidelle (Parente), Rui Baptista (Servo / Clístenes / Guarda), Bruno Fonseca (Ágaton), Inês Barbosa (Mulher), Sílvia Silva ( $1^{\text {a }}$ Mulher), Catarina Matos ( $2^{\mathrm{a}}$ Mulher), Cátia Oliveira (Coro), Joana Silveira (Coro), Marlene Alberto (Coro); Direç̧ão Cénica - Tó Maia; Figurinos - Tó Maia e Paula Santos; Direcção de Produção - Cátia Oliveira.

\section{MULHERES NO PARLAMENTO}

\section{Uma experiência sobre As mulheres no Parlamento} de Aristófanes

Produção: Alunos do décimo segundo ano da Escola Secundária Gonçalo Anes Bandarra (Trancoso)

Encenação e Adaptação: Paulo Mota

Tradução: Maria de Fátima Sousa e Silva

$1^{\text {a }}$ Apresentação: Convento de Trancoso

Data: 24. 4. 2002

Outras: Conimbriga, 27. 7. 2002 (IV Festival Internacional de Verão de Teatro de Tema Clássico, junho e julho de 2002).

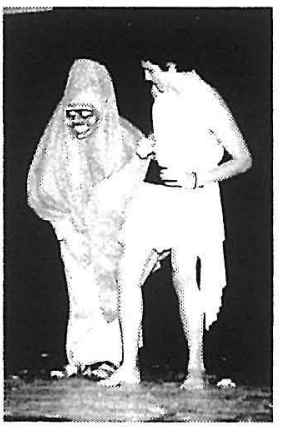

Alguns dos alunos do décimo segundo ano da Escola Secundária Gonçalo Anes Bandarra, com o apoio da escola, da Câmara Municipal de Trancoso e de Trancoso eventos, e sob orientação do professor Paulo Mota, encenaram As mulheres no Parlamento de Aristófanes, em tradução de Maria de Fátima Sousa e Silva.

O espectáculo foi precedido por uma breve apresentação em que Paulo Mota e a Bisnaga, além de agradecerem às instituições supramencionadas o apoio e de salientarem a importância do espectáculo no estreitar das relações entre escola e comunidade, alertavam o público para o facto de se tratar de uma peça que falava sobre a guerra dos sexos. Original foi o recurso, por parte dos apresentadores, a anedotas sobre a superioridade de cada um dos sexos, para dar o tom da peça. Apesar de se ter procedido ao corte de algumas brejeirices, as que tinham sobrado ainda poderiam escandalizar a assistência.

Ao fundo do palco estavam duas portas. Um pouco adiantado em relação à porta da esquerda do espectador encontrava-se um muro que teria sensivelmente metade da altura da porta e, mais à frente, ainda mais descaídas sobre os lados esquerdo e direito, duas janelas. Entre o palco e o público havia um espaço livre, que proporcionava aos actores uma maior proximidade em relação aos espectadores, maior interacção com eles e as 
constantes quebras da ilusão cénica, com alusões às diversas instituições da vila e às suas figuras mais emblemáticas.

Por limitações financeiras e de pessoal de apoio, as roupas eram modernas: as mulheres usavam os fatos escuros dos homens, e estes, ora calças de pijama e xaile, ora calças vincadas com as camisas por fora. As velhas vestiam saias mais ou menos escuras, blusas e lenços a condizer. $\mathrm{O}$ Moço tinha uma espampanante cabeleira postiça ruiva.

Do espectáculo fizeram parte músicas como o tico-tico no fobá, as iniciais das bandas sonoras de Os marretas e dos Ficheiros secretos, e ainda música popular.

A peça terminou com um banquete diante do palco.

Paulo Mota foi um Bléfiro bem convincente e Clarisse Seixas, uma Praxágora determinada. Vera Borges foi uma Pingóstrata que, mercê da influência do vinho, não conseguia acertar o passo nas coreografias apresentadas.

Foi um espectáculo divertido e comunicativo, que conseguiu mostrar a actualidade dos temas tratados no teatro clássico. Além disso, o entusiasmo dos alunos e do professor conseguiu contagiar o público e tudo acabou numa grande ovação e num alegre convívio em volta dos acepipes de uma mesa.

Elenco: Actores - Célia (Bisnaga, Mulher e Arauto), Clarisse Seixas (Praxágora), Vera Borges $\left(1^{\mathrm{a}}\right.$ Mulher e $1^{\mathrm{a}}$ Velha), Helena Augusto ( $2^{\mathrm{a}}$ Mulher e Moça), Paulo Mota (Bléfiro), Tony Pascoal (Homem), Sérgio Jerónimo (Cremes), Diogo Brás (Moço), Ana Costa (2 $2^{\mathrm{a}}$ Velha), Patrícia Ramos ( $3^{\mathrm{a}}$ Velha); Téenico de Som - Cláudio Pinto; Técnico de Luzes João Paulo; Técnico de Foco - Francisco; Sonoplastia - Paulo Mota e Tim.

Paulo Sérgio Ferreira

\section{PAZ}

Aristófanes, $\boldsymbol{A P a z}$

Produção: Companhia de Teatro de Almada

Encenação: Vítor Gonçalves

Tradução: Maria de Fátima Silva

$1^{\text {a }}$ Apresentação: Teatro Municipal de Almada

Data: 12-22. 6, 15-26. 10. 2003

Outras: Coimbra (TAGV), 23. 6. 2004.

A Companhia de Teatro de Almada levou à cena $A P a z$ de Aristófanes. O contexto internacional era propício a que se falasse de paz, quando o ataque aliado contra o Iraque se

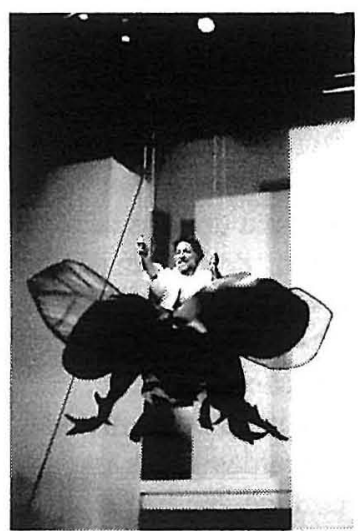


processava, perante uma larga contestação proveniente de diversos países. Correndo todos os riscos de confrontar um público moderno com a peça de 421 a. C., encomendada para celebrar, em Atenas, a paz de Nícias que então suspendia, por tempo escasso, o conflito com as forças do Peloponeso, passando por cima das características menos fulgurantes desta produção de Aristófanes, a Companhia de Teatro de Almada brindou os muitos espectadores que aderiram ao espectáculo com uma produção a todos os títulos meritória.

Decerto que a impressão geral mais imediata tem a ver com a vivacidade que se manteve uma constante em toda a representação. $O$ texto, desprovido de muitos dos recursos que fizeram a riqueza cómica de outras produções do poeta de Atenas, e enriquecido com outro tipo de elementos marcados por uma nostalgia sofrida perante a saudosa paz, tende a ser de alguma forma pálido de efeitos, e só a gesticulação apropriada e a boa exploração dos tons subjacentes ao texto permitiram torná-lo divertido e mobilizador.

A encenação foi também feliz. Valorizando o contraste branco / preto (paz / guerra), solucionou com recursos apropriados os aspectos especiais de cena que a peça coloca: o voo de Trigeu ao Olimpo sobre um escaravelho voador suspendeu Francisco Costa sobre um gracioso animal alado, que o fez elevar-se sobre a cena; o almofariz da guerra e o pilão exprimiram-se como uma simulação rolante que pôs em cena um efeito adequado; uma simples sanita isolada em cena, no início do espectáculo, marcou o tom do banquete servido ao escaravelho.

O texto foi integralmente respeitado, com todas as dificuldades que pode colocar a um público cronologicamente desfasado do contexto primitivo e muito do seu sucesso dependeu da forma como foi dito, sem permitir que momentos difíceis como a parábase deixassem cair o efeito. Para resolver o problema da sua pouca extensão, a peça foi acrescentada pela colagem do monólogo de Diceópolis, na abertura de Acarnenses, numa contaminatio que permitiu, de resto, fundamentar com os queixumes de um ateniense desgostoso com o rumo dos acontecimentos na sua cidade o voo utópico de Trigeu em busca de uma resposta dos deuses. Uma palavra de elogio é devida ao trabalho de actores e à solução do coro, que foi mobilizando os diversos actores, e que deu voz às preocupações colectivas sem privar cada um dos seus elementos de alguma individualidade; um compromisso, portanto, bem sucedido entre o individual e o cívico.

Elenco: Actores - Alfredo Sobreira (Guerra, $1^{\circ}$ Escravo, Coro), André Louro (Hermes, $2^{\circ}$ Escravo), Cátia Ribeiro (Filha, Coro), Francisco Costa (Trigeu), Luís Ramos (Hiérocles, Escravo, Coro), Maria Frade (Refrega, Coro), Miguel Martins (Vendedor de Armas, Coro), Filipa Moraes (Folgança), Susana Mendes (Deusa dos Frutos); Encenação - Vítor Gonçalves; Cenário e Figurinos - Maria João Vieira Ramos; Coreografia - 
Raquel Vieira de Almeida; Apontamento Musical - André Louro; Desenho de Luz - José Carlos Nascimento.

M. F. S. S.

\section{PLUTO}

Aristófanes, A Fortuna

Produção: Teatro ao Largo

Encenação: Steve Johnston

Iniciativa: TIC 2003

$1^{a}$ Apresentação: Tramagal

Data: 13. 12. 2003.

Elenco: Actores -Daniela Vieitas, Pedro Assis, Steve Johnston, Rui Penas; Música Original - Steve Johnston.

M. F. S. S.

\section{VESPAS}

Aristófanes, As Vespas

Produção: Grupo de Teatro Clássico Anankê

Encenação:

Tradução:

$1^{a}$ Apresentação:

Data: 2003.

O Grupo de Teatro Clássico Anankê levou à cena As Vespas de Aristófanes, mobilizando os seus doze elementos. A peça foi apresentada como

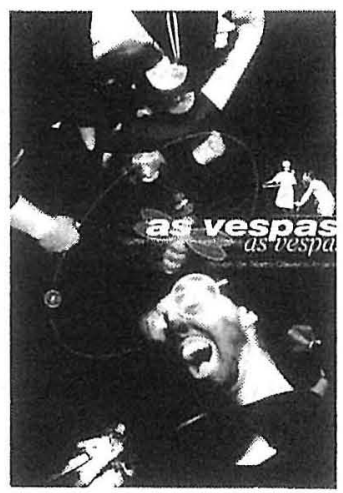
uma fábula em dois actos, que tem uma moral, 'não demasiado intelectual para vocês; conta a história de um velhote que sofre de uma doença peculiar, da qual, estou certo, nenhum de vocês ouviu falar e que não adivinharão a não ser que eu vos diga'.

Elenco: Actores - Pedro Almeida (Filócleon), Daniel Pais (Bdelícleon), Tânia Ferreira (Xântias, escravo), João Mourato (Um Cidadão / Sósio, escravo), Cláudio Torres (Um Rapaz / Cão / Midas), Ália Montenegro (Dardanis, jovem dançarina), Tânia Ferreira (uma Padeira); Coro de Vespas 
e de Pândegos - Rosa Martins (o Sonolento), Catarina Santos (Surdo), Marta Pinheiro (o Efeminado), Liliana Pereira (o Rebarbado), Ália Montenegro (o Tozze), Andrea Furtado (o Toma-notas), Sara d'Andrade (o Desdentado) .

M. F. S. S. 
(Página deixada propositadamente em branco) 


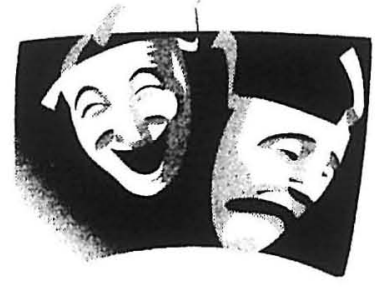

MENANDRO 
(Página deixada propositadamente em branco) 


\section{SAMIA}

\section{Menandro, La Samia}

Produção: Helios Teatro (Madrid)

Direcção e Encenação: Gemma López Martínez

$1^{\text {a }}$ Apresentação (em Portugal): Pátio da Universidade de Coimbra

Iniciativa: Encontros de Teatro de Tema Clássico

Data: 26. 6. 1999

Outras: Conimbriga, 27. 6. 1999; Conimbriga, Festival de Teatro Escolar de Tema Clássico, 2. 5. 2000; Coimbra (Museu Machado de Castro), 2. 5. 2001; Coimbra (TAGV) 11. 4. 2003.

Ver II Volume, pp. 166-168.

M. F. S. S. 
(Página deixada propositadamente em branco) 


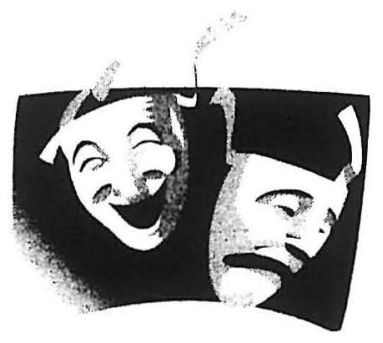

ADAPTAÇÕES DE TEMAS GREGOS 
(Página deixada propositadamente em branco) 
Rodrigo Garcia, After Sun

Produção: La Carniceria Teatro

(Argentina/Espanha)

Encenação: Rodrigo Garcia

$1^{\text {a }}$ Apresentação em Portugal: Citemor,

XXIII Festival de Montemor-o-Velho

(Sala B)

Data: 27-29. 7. 2001.

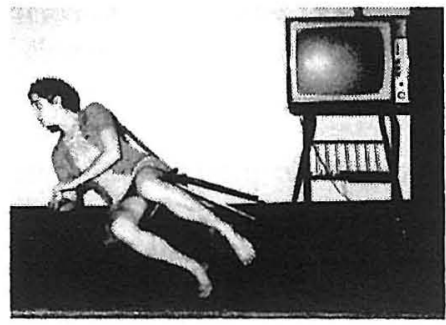

A $23^{\mathrm{a}}$ edição do Citemor decorreu entre 21 de Julho e 11 de Agosto e, como tem sido hábito, as artes dramáticas tiveram uma presença marcante, com a participação do Teatro da Garagem, dos Artistas Unidos e a estreia do grupo espanhol La Carniceria Teatro, fundado por Rodrigo Garcia. A sua peça era aguardada com alguma expectativa, pois antes de ser apresentada em Portugal já havia despertado grande interesse e dividido o público europeu, sobretudo na Grécia e na França.

After Sun é fruto de uma encomenda do X International Meeting of Ancient Drama, mas viria a causar escândalo pela singular abordagem do mito de Faetonte. Cumpria, no entanto, os requisitos propostos pelos directores do festival de Delfos: que os dramaturgos apresentassem uma versão original e breve de um mito grego, que pudesse ser apresentada num espaço pequeno (o Museu de Delfos) e não exigisse grandes dispositivos cénicos. Rodrigo Garcia seria um dos três escolhidos e a peça foi apresentada em 3 de Julho de 2000. Causou estranheza e polémica, porque não se relaciona directamente com o mito, que apenas é evocado brevemente no início da performance (José Monleón, "After Sun, un pequeño relámpago sobre Delfos", Primer acto. Cuadernos de investigación teatral $\mathrm{n}^{\circ} 285,2000$, p. 23). O título, porém, é sugestivo, pois joga ironicamente com o nome Sol, pai de Faetonte, e com a designação comercial 'after sun' dada aos protectores solares. Como é sabido, no mito grego, Faetonte perde a vida fulminado pelo pai, que assim evitou uma conflagração universal. Mas na versão de Rodrigo Garcia, a acção é contemporânea e decorre numa Terra à beira da ruína, na qual se despenhou o Sol conduzido pelo seu desastrado filho.

$\mathrm{O}$ autor e encenador, de origem argentina, é considerado uma figura singular no meio teatral espanhol. Nas suas palavras, o seu teatro "não faz parte de uma sociedade de espectáculo", "é muito crítico com o sistema da vida", "não é comercial, não é burguês, não alegra as pessoas. Pelo contrário, pretende a confrontação com o público." (entrevista concedida ao Público de 27. 7. 2001). Esteticamente, After Sun é um espectáculo despojado de adereços, que assenta principalmente na performance, na expressividade corporal dos dois actores, Juan Loriente e Patricia Lamas, e na iluminação de Carlos Marquerie, em detrimento da palavra. Do ponto de vista ideológico, aparentemente 0 encenador não tem a pretensão de fazer passar uma 
mensagem explícita, as contradições do texto são intencionais, mas o resultado final é a denúncia da violência e da falta de humanidade do mundo actual. Trabalho que alguns consideraram agressivo e incómodo, pela nudez dos actores e pela violência da representação, "formalmente muito claro" na descrição do próprio autor (ibidem), After Sun é, em resumo, uma crítica à ambição desmesurada com que convivemos todos os dias, de todos quantos procuram o protagonismo, seja através da pesquisa cientifica, seja através de outros meios tão diversos como a política, a moda, o cinema, o futebol... "Mayor es la altura, mais dura será la caída..."

Luísa de Nazaré Ferreira

Igor Stravinsky, Apollon Musagète

Produção: Ballet Opéra de Paris

Coreografia: George Balanchine

Iniciativa: Noites de Bailado

$1^{a}$ Apresentação: Sintra, Jardins do Hotel-Palácio de Seteais

Data: 25-27. 8. 1995.

Balanchine optou por reduzir a três o número das Musas do séquito de Apolo: Calíope, Polímnia e Terpsícore, porque as considera "as mais representativas da arte coreográfica": a primeira, que "personifica a poesia e os seus ritmos", a segunda que, com um dedo nos lábios, "figura a mímica" e - evidentemente - Terpsícore, a quem é dado um lugar de honra junto do deus, por ser a Musa da dança.

Elenco: Bailarinos - Bénédicte Cardon, Aurélie Dupont, Clairemarie Osta, Jean-Yves Lormeau.

Ana Paula Quintela Sottomayor

\section{G. Balanchine e I. Stravinsky, Apollo}

Produção: Companhia Nacional de Bailado

Director Artístico: Mehmet Balkan

Coreografia: Patrícia Neary

$1^{a}$ Apresentação: Lisboa (Teatro Camões, Parque das Nações)

Data: 15.3. 2000

Outras: Lisboa (Teatro Camões, Parque das Nações), 25-28.10. 2001; Coimbra (TAGV), 15. 2. 2002; Lisboa (Teatro Camões, Parque das Nações), 25. $10-3.11 .2002$.

Ver Vol. II, pp. 186. 
H. von Hofmannsthal/Richard Strauss, Ariana em Naxos/Ariadne auf Naxos Produção: Teatro Nacional de S. Carlos Maestro Director: Zoltán Peskó Libreto: Hugo von Hofmannsthal Récita: Lisboa, Teatro Nacional de S. Carlos Data: 17, 19, 21, 23 e 25. 5. 2003.

Ariadne auf Naxos é um dos espectáculos onde, por excelência, se aborda o tema do «teatro no teatro». Estruturada em dois momentos distintos, um Prólogo, no qual se

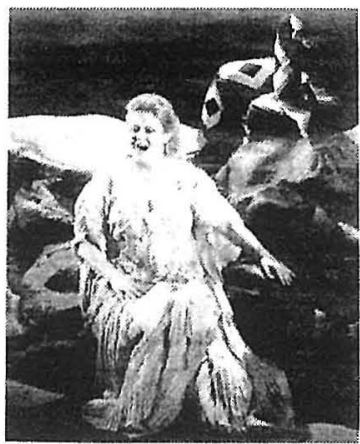
prepara a encenação de uma ópera dedicada ao tema de Ariadne e Dioniso, e a ópera propriamente dita, este libreto de Hofmannsthal acaba por ser uma reescrita de um mito clássico, muito ao gosto dos finais do século XIX, inícios do século $\mathrm{XX}$, pois foi uma época áurea, nomeadamente na Alemanha, para as interpretações da mitologia clássica. A Elektra de Hofmannsthal é um desses exemplos, mas o tema de Ariadne foi dos primeiros e mais tratados operaticamente, como se pode facilmente verificar pelas obras de Bonacossi (Arianna abbandonnata da Teseo e sposata dal Dio Baccho, 1641), Porpora (Arianna in Nasso, 1733), Monteverdi (Arianna), Händel (Arianna in Creta, 1734), Benda (Ariadne auf Naxos, 1775), Massenet (Ariane, 1906), Milhaud (L'abandon d'Ariane, 1928). Estas personagens clássicas, contudo, renascem com novas funções, com uma dimensão moral própria da cultura cristã, mais que da greco-latina.

Segundo o encenador desta produção, o tema essencial que subjaz à Ariadne de Hofmannsthal/Strauss é a lealdade/ingratidão e as inconstâncias na vida, simbolizadas pelas personagens de Ariadne e Zerbinetta e pela evocação da de Teseu. Acima de tudo, realça-se a complexidade da vida. Talvez por isso também, o cenário passa por uma alteração radical de um acto para outro, quando muda de um teatro para uma ilha fantástica. Acentuar a atitude de ingratidão, como faz o autor do libreto, na figura de Teseu, criando assim a ingratidão masculina, esquecendo o eventual papel que Fedra tem no mito grego e no abandono de Ariadne em Naxo poderá ser injusto para a personagem de Teseu.

Uma das particularidades desta encenação é o facto de a acção ter sido situada no presente, um recurso que vai já sendo vulgar em muitas produç̃es contemporâneas de teatro clássico que, ao mesmo tempo, denuncia uma necessidade velada dos actuais produtores e encenadores «presentificarem» tudo, como se houvesse alguma incapacidade dos públicos compreenderem a essência das palavras em cenários ou trajes adequados às épocas do enredo original. A justificação, porém, é quase sempre a mesma: trata-se de um clássico e por isso pode ser encenado em qualquer época. Mas 
não podemos deixar de crer que, ainda que interessantes, tais actualizações só contribuem para desvalorizar o espírito fundamental destes textos. Além de que se perde a faceta de espectáculo de época que contribui para a encenação. Nas opções de T. Servillo, é como se o público estivesse na sala de um palácio e assistisse à chegada dos cantores e dos comediantes que se preparam para ensaiar a sua Ariadne em Naxo.

Quanto à parte especialmente dedicada ao mito grego, ela é pouco rica em motivo de enredo: Dioniso/Baco chega a Naxo e encontra Ariadne adormecida, depois de ter sido abandonada por Teseu. Primeiro, pensa que se trata de uma feiticeira, evocando a figura de Circe. Por sua vez, também Ariadne se engana, pensando que se trata de Teseu que ainda está junto dela. Gera-se o mal-entendido, que será resolvido com a ajuda da belíssima música de Strauss.

Em Lisboa, a interpretação de algumas destas figuras foi negativamente criticada, considerando-se os desempenhos de I. Storey, como Baco, e de E.-M. Wachutka, como Ariadne, enfadonhos e desmotivadores. Por outro lado, elogiou-se a interpretação de S. Lorenz, como o Compositor (DN, 23.5 .2003$, p. 48).

Uma palavra para o texto que acompanha esta encenação. Nele lemos o seguinte: «Na mitologia "académico-burguesa" do "establishment" grego do século V, o episódio da rainha Pasifaé (sic) dentro da vaca oca toma foros de troca de quartos numa comédia de "boulevard"». Não compreendemos o que o seu Autor entende por «mitologia "académicoburguesa"», e não deixa de ser muito curiosa a utilização do termo «burguesa» ao século $\mathrm{V}$ a.C., visto tratar-se de um anacronismo básico. $\mathrm{O}$ mesmo se diga de «"establishment" grego». Qual? O de Atenas? O de Esparta? O de Corinto? O de Micenas? Trata-se de um conceito que dificilmente se pode aplicar ao século $\mathrm{V}$ grego. E ainda que Pasífae fosse um motivo de «boulevard», isso seria certamente muito grego ou até mesmo latino, visto que a comédia de costumes nasceu também na Antiguidade Clássica. Do mesmo modo, é muito infeliz a utilização da onomástica clássica nestes textos, onde lemos nomes como «Pasifaé», "Dionísio» (um caso de erro básico), «Elektra», «Chrysothemis» ou «Klytamnestra», todos eles nomes com correspondência portuguesa perfeitamente definida e publicada.

Elenco: Cantores - Richard Jaeckie (Mestre de Cerimónias), Siegfried Lorenz (Professor de Música), Michelle Breedt (Compositor), Ian Storey (Tenor, Baco), Francisco Lobão (Oficial), Ferdinand Seiler (Professor de Dança), João Miranda (Cabeleireiro), Pedro Correia (Lacaio), Vassiliki Karajanni (Zerbinetta), Elisabeth-Maria Wachutka (Primadonna, Ariadne), Luís Rodrigues (Arlequim), Carlos Guilherme (Scaramuccio), Hye Soo Sonn (Truffaldin), Corby Welch (Brighella), Marta Kosztolanyi (Naiade), Kathrin Hildebrandt (Dríade), Dora Rodrigues (Eco), Orquestra Sinfónica 
Portuguesa; Encenação - Toni Servillo; Cenografia - Toni Servillo, Daniele Spisa; Figurinos - Ortensia de Francesco; Desenho de Luzes - Pasquale Mari; Assistente de Encenação - Marinella Anaclerio; Assistente de Cenografia - Angelita Borgheresi; Assistente de Figurinos - Jessica Zambelli; Maestros Assistentes - João Paulo Santos, Fernando Fontes; Maestro Correpetidor - Nuno Lopes; Execução do Cenário - Bottega Veneziana; Adereços - Teatro Nacional de S. Carlos; Guarda-Roupa Tireli; Calçado - Pompei; Caracterização - Fátima Sousa.

Nuno S. Rodrigues

Atlântida, o continente perdido

Produção: Walt Disney Pictures

Argumento: Tab Murphy

Duração: $93 \mathrm{mn}$

Estreia: 8. 12. 2001 (Portugal); 15. 6. 2001

(USA); 19. 10. 2001 (UK).

O filme de animação produzido pelos estúdios da Walt Disney em 2001, Atlantis, the lost Empire, corrobora a constatação clara para os estudiosos de Platão, primeira fonte escrita a

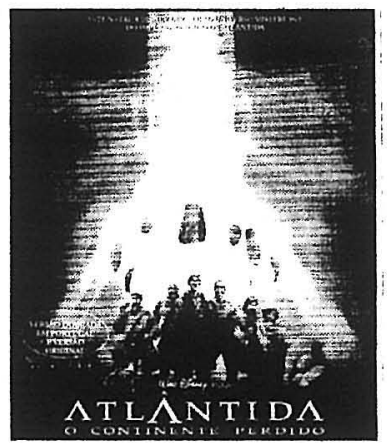
referir a extinção da Atlântida, de que, apesar de inacabado, esse seu mito se constitui como o mais influente fora da tradição filosófica. A matriz grega adquire, aliás, o estatuto de incipit, ou seja de 'página de rosto', da fita, pois esta abre com uma breve citação das palavras do fundador da Academia dando conta do desaparecimento, num único dia, da civilização faustosa da Atlântida. Tratando-se da reprodução de um texto a ter chegado aos nossos dias, estranham os espectadores adultos a ausência da identificação da obra a que pertence o passo (Timeu 24 a-d). Tal omissão não obsta ao cumprimento daquele que parece ter sido o desígnio de iniciar o filme com o testemunho mais antigo sobre a Atlântida: denunciar o alicerce mais sólido de um mito incompleto, logo, na perspectiva dos receptores, revestido de mistério e fascínio redobrados - o aniquilamento abrupto de um povo e de um espaço.

A proposta do filme assenta precisamente em colocar as suas personagens na demanda de algo que se julga acabado, mas de que é possível comprovar uma existência passada real. Para isso basta revelar ao mundo vestígios da mesma e nada melhor do que fazer do protagonista um explorador / arqueólogo, especializado em cartografia e linguística. De facto são essas duas competências que apetrecham Milo Thatch de saberes fundamentais para possibilitar a localização exacta do lugar onde se perdeu o rasto da Atlântida - na Islândia - e a decifração da língua desse povo. Do 
esforço bem conseguido da equipa de produção do filme para criar um mundo sobretudo desconhecido, como o da Atlântida, destacamos a invenção de uma escrita e de uma língua autóctones. Conforme declaram os realizadores no making of incluído no DVD, foi necessário um imenso trabalho de pesquisa por forma a permitir reconstruir uma lenda na qual transparecesse o cruzamento das inúmeras teorias surgidas ao longo dos tempos sobre a Atlântida, a que não fosse alheia a primazia da novidade.

Do legado clássico grego temos, para além da evocação das palavras do filósofo, a ideia de a missão de descoberta do continente perdido ser uma catábase, uma descida, não aos Infernos, como fizera Ulisses no canto XI da Odisseia, mas ao interior da terra, qual Vinte Mil Léguas Submarinas de Júlio Verne. Também Milo e os seus companheiros desceram num submarino, cujo nome, Ulisses, remete para o primeiro herói da literatura ocidental a cometer a proeza de penetrar no interior de um mundo velado aos homens (seja ele o Hades homérico ou o interior da terra). Além da internet, primeira e profícua fonte de investigação usada, houve um documentário televisivo que colocou a equipa de realização da película a par da tese segundo a qual a erupção de um vulcão em Santorini teria sido a catástrofe natural responsável pelo fim da Atlântida. Ainda que de forma enviesada, o filme faz eco dessa explicação através de uma das personagens. Vinny, o especialista em explosivos que integra a missão, tem por nome completo Vincenzo Santorini.

Do seio da tradição bíblica surge o maior perigo enfrentado pelo submarino Ulisses e respectiva tripulação, o monstro aquático Leviathan. Encarnação do caos (cf. Salmo 74, 14), a verdade é que o papel da fera marinha na história é de semear a destruição total ao seu redor.

Apesar de representar uma viragem no estilo da animação Disney, sobretudo devido ao conteúdo da história e aos próprios desenhos, Atlantis, the lost Empire, não colheu o aplauso entusiasta do público. Imbuída de um espírito de aventura que remete o receptor de imediato para o chamado 'estilo Indiana Jones', apostada em romper com a linha de musicais que marcam a Disney desde $A$ Branca de Neve, é a mesma equipa que realizara $O$ Rei Leão e $A$ Bela e o Monstro que apresenta em 2001 a Atlântida. Nem mesmo a homenagem ao desenhador de cartoons Mike Mignola, denunciada no traço (vejam-se os dedos rectangulares das figuras), foi compreendida. Aliás, uma das críticas mais constantes dirigidas ao filme foi precisamente a de parecer que as imagens editadas correspondiam aos esboços e não ao que devia ser a versão definitiva. 


\section{A Aventura de Ulisses}

Produção: Cultural Kids

Encenação: António Feio

Dramaturgia: Maria João Cruz, Patrícia

Castanheira

$1^{a}$ Apresentação: Lisboa, Teatro Nacional D.

Maria II, Sala Garrett

Data: Fevereiro, até 27. 4. 2002

Outras: Porto (Teatro de S. João), Novembro de 2004; Viseu (Teatro Viriato),

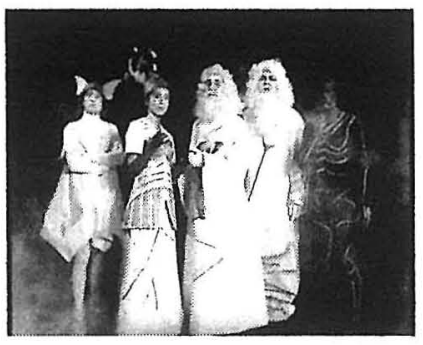

4-5. 10. 2002; Lisboa (Teatro Nacional D. Maria II), 13-23. 5. 2003; Sintra

(Centro Cultural Olga Cadaval), 27. 5 - 1. 6. 2003.

Numa adaptação da Odisseia de Homero, a Cultural Kids pretendeu visar um público infantil ou adolescente e produzir um espectáculo sensibilizador relativamente a referências culturais e a modelos estéticos de transmissão. A primeira adaptação visou o texto, escrito em escassas páginas, sob uma forma divertida e leve, de ritmo bem adaptado a um português escorreito e jovem. Se a adaptação das palavras é profunda, embora narre pedaços de uma história que detém já 3000 anos de existência, a revolução operada sobre o lado visual do espectáculo não é mais leve: porque os computadores são absorvidos como a arma principal de Zeus e dos deuses do Olimpo, que, pela magia dos seus programas, põem em movimento o herói e as suas campanhas como mero centro de um jogo arbitrariamente movido pelo capricho divino. Se a versão cómica para teatro da saga de Ulisses tem uma tradição que já a Antiguidade considerava desgastada, nunca como nos nossos dias ela se pôde exprimir de uma forma multimédia, onde os actores contracenam com imagens de computador que, por magia da sua própria vontade, os enquadram num pano de fundo electrónico que define o espaço de cena.

O espectáculo foi arquitectado segundo um conceito assim definido pelos seus criadores: 'A Odisseia de Ulisses é transformada num jogo, com estrutura e desenvolvimento semelhantes aos de um jogo electrónico. Este jogo é criado e controlado pelos deuses - os grandes programadores do mundo - que, após o final da guerra de Tróia, decidem lançar novos desafios a Ulisses. O regresso do herói a Ítaca é o objectivo final deste jogo, correspondendo cada aventura a um nível em que se ganham ou perdem objectos, capacidades e pontuações'. A cada um dos intervenientes é dada, neste jogo, uma posição explícita: os deuses, supremos manipuladores do jogo, ocupam em cena um lugar elevado, o que lhes dá física e visualmente o contexto mais adequado à actuação que lhes cabe: tudo gerem, das alturas do espaço, ao controlo dos botões obedientes do computador; Ulisses é o velho senhor de Ítaca, ignorante das condicionadoras vontades de que é alvo, 
sempre movido pelo objectivo firme do regresso à pátria e aos seus; o espaço que lhe convém, central na acção, é o palco, enquadrado por referências a Ítaca em pano de fundo; por fim, os espectadores estão numa posição omnisciente, atentos aos deuses manipuladores e ao herói manipulado. É-lhes facultado, por milagre da moderna tecnologia, o acesso à tradução electrónica do jogo, através de um painel que dele projecta o menu e que garante, por diversas recapitulações, que o jovem espectador não perderá nunca a ponta da meada nesta experiência labiríntica ao lado de Ulisses.

$\mathrm{Na}$ estrutura da acção, aos deuses compete dar o tom de abertura e de fecho, através de dois dos seus memoráveis concílios. Com recurso a computadores, que agora enchem as mesas de trabalho do Olimpo, pode-se recapitular, com o apoio dos comentários divinos e das imagens sobre os écrans, os antecedentes da guerra de Tróia, o comportamento de Ulisses e sobretudo a contribuição engenhosa que o cavalo de madeira representou para a solução da campanha. Na leitura interpretativa do passado, as vontades olímpicas dividem-se, entre os que aplaudem a excelência do herói e the reservam a sua simpatia, e os que lhe censuram a arrogância e a concorrência, e por isso the prometem perseguição e castigo. A harmonia só se consegue, no Olimpo, pela decisão unânime de sujeitar o herói a uma série de desafios, outras tantas etapas de um jogo electrónico, que terá de vencer para conseguir o eterno objectivo: rever as praias amadas de Ítaca. Barco, tripulação e pontuação de base estão a postos para que o jogo possa começar.

É então a vez de a saga de Ulisses ocupar o centro das atenções. O roteiro convencional de portos e de perigos que os navegadores míticos percorrem, o cortejo de amigos e de inimigos com que cruzam, os incentivos ou barreiras fornecidos à prossecução da viagem são os homéricos: Cícones, Lotófagos, Ciclopes, Éolo, como Circe, Hades, as sereias, Cila e Caríbdis, as vacas do sol ou a ilha de Calipso, impõem ao Ulisses 2002 o decalque dos movimentos do seu antepassado de há milhares de anos. De novo apenas a pontuação electrónica que permite agora traduzir e contabilizar, num painel em constante actualização, a soma de êxitos e fracassos que constituem a eterna saga. Como sempre também o grande final é a chegada, em que 'o game over coincide com o beijo do reencontro entre Penélope e Ulisses'. Uma última palavra cabe aos imortais, num breve concílio final, onde se avalia o desempenho vitorioso de Ulisses no jogo de que os Olímpicos são os autores.

M. F. S. S.

\section{Barthes \& Mandrake}

Encenação: Rosa Coutinho Cabral

$1^{a}$ Apresentação: Teatro Taborda

Data: 27-29. 12. 2001. 
Barthes \& Mandrake é um espectáculo teatral criado livremente a partir da obra Fragmentos de um discurso amoroso, de Roland Barthes, e de duas personagens da Banda Desenhada: 'Mandrake', de Lee Falk e Phil Davis, e 'A Menina Inclinada', de François Schuiten e Benoît Peeters. No palco cruzam-se diversas formas de arte (dança, canto, música e instalação) e atravessam-no as personagens inventariadas por Roland Barthes (a Dama das Camélias de Dumas, Werther e Carlota de Goethe, Heathcliff de Emily Bronté), sob o olhar impaciente e, por vezes, estupefacto, de um Encarregado. As suas falas correspondem ao "discurso do apaixonado que fala e diz", como escreveu Barthes. Com as figuras amorosas do seu arquivo dialogam outras personagens menos românticas, no sentido literário do termo, como as Alices (No país das maravilhas e Do outro lado do espelho) de Lewis Caroll, embora se destaquem as de um "lote grego", Diotima e Sócrates, talvez porque sejam dignas "de respeito, de admiração e de estima universal", segundo afima a angustiada Dama das Camélias (Cena 11).

As personagens do Banquete de Platão não são as únicas referências clássicas. O monólogo do deus Eros, de rosto iluminado e uma voz hipnótica, abre este espectáculo "sobre o amor, ou melhor, sobre uma leitura do comportamento das pessoas em situação de amor por alguém, por uma causa." No sentido de mostrar o "inexprimível amor", na Cena 5, Diotima e Sócrates "vão-se concentrar nos enganos, debates, e impasses a que dá lugar o desejo de 'exprimir' o sentimento de amor numa criação (especialmente da escrita)." Na Cena 7, Diotima, "mistura de bruxa má", voltará a aparecer para se insurgir contra a intromissão no arquivo do discurso amoroso de Barthes de personagens como Alice, "aberrações da escrita que desafiam a lógica do espaço", nas palavras do Encarregado. Este procura a todo o custo manter o formato original do arquivo, repor a ordem que Mandrake, "que tem cara de quem não ama ninguém" (Cena 12), vai tentar perturbar. Quando a personagem de $\mathrm{BD}$ consegue, finalmente, imobilizar o organizador do arquivo e fazer sair as figuras dos seus lotes, Diotima e Sócrates mantêm-se "imperturbáveis", com os traços originais e as palavras que Platão thes deu (Cena 17). No entanto, as outras personagens "pré-configuradas" também não conseguem conviver com a liberdade que Mandrake lhes oferece. A este, "sendo o que não tem amor", resta-lhe a tarefa de "ligar o bem e o mal, o amor e o ódio, o finito e o infinito, o visível e o invisível, o conhecimento e a ignorância, a vida e a morte...", assumindo, nas palavras finais de Eros, a função de ligar eternamente todos os arquivos de todos os discursos.

Elenco: Actores - Custódia Gallego, Marina Nabais, Hugo Amaro, Inês Sousa, Isabel Marques, João Cabral, Leonor Trigueiros, Madalena Lourenço, Maria Galhardo, Miguel G. Mendes, Rafaela Santos, Rogério Nuno Costa, Selma Sifka; Texto Dramatúrgico - Rosa Coutinho Cabral, José Carlos Pontes e Hugo Amaro; Música Original - José Carlos Pontes; Tenor - Gustavo de Matos Sequeira; Assistência de Encenação - Hugo 
Amaro; Guarda-Roupa - Rosa Coutinho Cabral; Video - Rosa Coutinho Cabral; Design de Luz - Carlos Gonçalves; Direcção de Produção Filomena Oliveira; Apoio à Produção/Contra-regra - Cristina Braziel; Ilustração do Cartaz - Eduardo Salavisa; Design do Cartaz - José Carlos Pontes.

Luísa de Nazaré Ferreira

Oh brother, where art thou?

(adaptação livre da Odisseia)

Realização Cinematográfica: Jean

Cohen e Ethan Cohen

Encenação: François Tanguy

$1^{\text {a }}$ Apresentação (em Portugal): Lisboa

(Amoreiras, Colombo, King, Saldanha);

Porto (AMC, Cidade do Porto)

Data: Março de 2001.

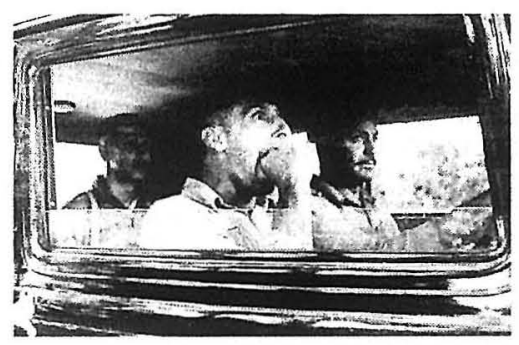

O nome desta película dos irmãos Cohen (traduzido em português como "Irmão, onde estás?") não deixa adivinhar aquilo que é logo anunciado na abertura do filme, através da invocação à Musa: que estamos perante uma paródia da Odisseia de Homero. De resto, o tradicional patriarca da poesia épica é evocado através da figura de um velho cego, que acumula as funções de profeta, enquanto impulsiona, lentamente, uma plataforma que avança sobre os carris do comboio. O espaço da Odisseia é transposto para os arredores de uma prisão, no Sul dos EUA, no decurso dos anos 30. É durante os trabalhos forçados que escapam três dos prisioneiros, comandados por Everett Ulysses McGill (George Clooney), que os convencera a participar na fuga através da miragem fugaz de um tesouro prestes a desaparecer sob as águas de uma barragem. Este Ulisses anti-heróico tem, como o antecedente homérico, grande facilidade de discurso; de resto, não será por acaso que o crime que o levara à prisão tenha sido o facto de se passar por advogado convincente, sem estar devidamente credenciado. Possui, no entanto, menos habilidade para se livrar dos problemas em que se vê envolvido, embora a mão da boa fortuna o conduza à vitória final. E o que este Ulisses (com traços de Clark Gable) pretende mais não é do que regressar a casa (Ithaca) e recuperar a confiança da sua mais do que zangada "Penny" (Holly Hunter), que está prestes a desposar um pretendente.

Estamos perante uma releitura bem disposta da Odisseia, como ilustram algumas curiosas alterações introduzidas pelos irmãos Cohen. Everett Ulysses McGill não tem um filho Telémaco, mas antes sete filhas pequenas a quem a mãe tenta convencer de que o pai morreu, para não ter de 
lhes contar o motivo por que ele havia desaparecido; Ulysses luta com o pretendente, mas é claramente levado de vencida; conhece um Polifemo (John Goodman), pregador com uma pala no olho, que o vigariza sem qualquer contemplação. Mas talvez o episódio mais curioso corresponda às "Sereias" do rio (onde insensivelmente se fundem os poderes da feiticeira Circe), as quais, com o seu canto, atraem os três fugitivos, na expectativa de os entregarem às autoridades e de receberem a recompensa.

Esta Odisseia pitoresca dos anos 30 vive ainda, em larga medida, das alusões ao universo literário e cinematográfico daquela época, de forma que a presença de Homero acaba por não ser tão insistente quanto parecia anunciar a invocação inicial. Constitui, contudo, um curioso exemplo de como a herança clássica pode colher as atenções da Sétima Arte. E embora não tenha atingido o sucesso nem a grandiosidade do Gladiador, este filme dos irmãos Cohen conquistou, além do sucesso de bilheteira, duas nomeações para os "Óscares" e um "Globo de ouro" para o melhor actor de comédia (George Clooney).

D. F. Leão

\section{Frank Wedekind, Lulu. La Capsa de Pandora (una tragèdia-monstre)}

Tradução para Catalão: Feliu Formosa

Produção: Teatro Nacional da Catalunha

Encenação: Mario Gas

Iniciativa: Festival Internacional de Expressão Ibérica - FITEI

$1^{\text {a }}$ Apresentação: Porto, S. João

Data: $31.5-2.6 .2001$.

Uma vez que o texto original, escrito em 1892, foi proibido como "imoral e inestético", o autor só três anos mais tarde conseguiu publicá-lo, dividindo-o em duas peças: $O$ espírito da Terra e $A$ Boceta de Pandora. Em 1913, o autor reuniu de novo as duas partes em Lulu - personagem imortalizada pela actriz Louise Brooks, no filme de G. W. Pabst, A Boceta de Pandora.

A encenação, a cargo do uruguaio Mario Gas, segue a primeira versão - «a mais explosiva», segundo o encenador - e convida-nos, logo no início do prólogo, a entrar no circo mundano, através das palavras de um domador que atravessa uma arena de circo de chicote e revólver em punho. A peça em cinco actos, considerada por Karl Krauss «grotesca como a própria vida», mas que, segundo Thomas Mann, «apesar de conter elementos algo problemáticos, ocupará sempre um lugar de destaque na história do teatro alemão», apresenta, nas palavras de Mario Gas, «um texto que ridiculariza aspectos obscuros e contraditórios dos seres humanos». Com efeito, Lulu, uma prostituta bela e selvagem, revela-se uma personagem isenta de culpa 
que representa o mito da mulher anjo-demónio: o símbolo da libertação dos demónios do desejo humano e a recusa da feminilidade como ela é vista por uma perspectiva masculina dominante.

A peça estreou a 8 de Março em Barcelona.

Elenco: Actores - 21, todos catalães; Cenografia - Jon Berrondo; Figurinos - Antonio Belart; Desenho de Luzes - Ignasi Camprodon; Banda Sonora - Marta Carrasco.

José Luís Brandão

Cassandra ( a partir da obra de Christa Wolf)

Produção: Grupo de Teatro Experimental Mirita Casimiro

Encenação: Cristóvão Cunha

Adaptação do Texto: Carla Augusto, César Zembla

Iniciativa: IV Festival de Teatro Jovem

$1^{\mathrm{a}}$ Apresentação: Auditório Mirita Casimiro

Data: 1. 6. 2003.

Elenco: Actores - Cláudia Cesário; Cenografia - Paulo Matos, Cristóvão Cunha; Figurinos - Rodrigo Gonçalves; Desenho de Som Anatol Waschke; Fotografia - Lisa Hanna; Banda Sonora Original - Nora Luca.

M. F. S. S.

Les Cantates (textos de Plutarco e de Sófocles)

Produção: Théâtre du Radeau

Encenação: François Tanguy

Iniciativa: PoNTI / Porto 2001/ Teatro Nacional de S. João

$1^{\text {a }}$ Apresentação: Porto, Parque da Cidade

Data: 2-7. 10. 2001.

O trabalho desenvolvido pelo Theâtre du Radeau caracteriza-se pela questionação constante das possibilidades da dramaturgia; não tanto a dramaturgia clássica ou moderna, mas antes a sua própria dramaturgia. Com Les Cantates, combinam-se textos retirados de autores tão díspares como Dante, Tasso, Kirkegaard, Nietzsche, Rilke, Plutarco ou as Antígonas de Sófocles, Hölderlin e Brecht.

François Tanguy descreve esta produção como uma «oração profana à decantação das nuvens de violência que assaltam os corpos e os espíritos», desígnio que transforma "Les Cantates numa cartografia mental e física da 
geologia das almas e dos corpos, que, por aspiração, viajam dos abismos para a luz, da luz para a penumbra, da penumbra para as explosões de alvura».

D. F. Leão

Luigi Dallapiccola, Cinque Frammenti di Sappho

Produção: Remix Ensemble

Organização: Casa da Música

Direcção Musical: Yoichi Sugiyama

Soprano: Alexandra Moura

$1^{\text {a }}$ Apresentação: Coimbra, TAGV

Data: 13. 2. 2004.

M. F. S. S.

Paulo José Miranda, $O$ Corpo de Helena

Produção: Grupo de Teatro Agôn

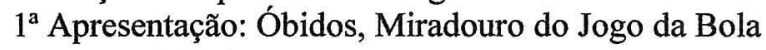

Data: 31. 8. 2003.

M. F. S. S.

Maurice Ravel, Daphnis et Cloé (extractos)

Produção: Ballet Opéra de Paris

Coreografia: George Skibine

Iniciativa: Noites de Bailado

$1^{a}$ Apresentação: Sintra, Jardins do Hotel-Palácio de Seteais

Data: 25-27. 8. 1995.

Desta famosa sinfonia coreográfica de Ravel apenas foi executado o pas-de-deux do $3^{\circ}$ acto.

Elenco: Bailarinos - Clairemarie Osta, Nicolas Le Riche.

Ana Paula Quintela Sottomayor

Diotima (a partir de Maria Zambrano, Diotima de Mantineia)

Produção: Teatro Praga

Encenação: Paula Diogo

$1^{a}$ Apresentação: Fábrica da Pólvora - Lugar Comum, sala 28

Data: 5-8. 3. 2001

Outras: Lisboa (Hospital Miguel Bombarda), Junho de 2001. 
Profetisa lendária que surge no Banquete de Platão para tecer algumas considerações sobre o amor, Diotima é a figura à volta da qual se constrói esta produção do Teatro Praga.

Baseada na obra intitulada Diotima de Mantineia da escritora espanhola Maria Zambrano, esta peça partiu de uma ideia de Paula Diogo e reuniu pessoas de várias áreas, nomeadamente de filosofia, teatro, vídeo e música.

É de realçar que a entrada era livre.

Elenco: Actores - Joana Pereira, Pedro Penim, Gonçalo Alegria, Paula Diogo, Carlos Alves, David Dias, Sandra Simões, entre outros.

Cláudia Cravo

Dust (adaptação da Odisseia)

Produção: Indefinite Articles

Iniciativa: Festival de Marionetas do Porto

$1^{\text {a }}$ Apresentação: Londres (BAC 2), 2001

$1^{\text {a }}$ Apresentação em Portugal: Porto, Teatro Rivoli

Data: 10. 12. 2001

Outras: Bath International Puppet Festival, 24. 4. 2003.

A Indefinite Articles foi fundada por Steve Tiplady em 1995 e é considerada uma das companhias britânicas de marionetas mais inovadoras da actualidade. No Festival de Marionetas do Porto apresentou Dust, uma criação de Steve Tiplady, Sally Brown e Zannie Fraser a partir da Odisseia, dirigida a crianças com mais de 11 anos. Realidade e mito misturam-se em cena. Três executantes (um homem e duas mulheres), três projectores suspensos e três baldes de poeira combinam-se a fim de criarem imagens que ilustram as aventuras de Ulisses e da sua tripulação. Nas palavras de João Quaresma (Jornal de Notícias, 10. 12. 2001): "Utilizando a poeira, água, o corpo humano e fontes luminosas móveis, 'Dust' propõe uma dupla narrativa da Odisseia de Homero."

Luísa de Nazaré Ferreira

Jorge de Sena, Epimeteu ou o homem que pensava depois

Produção: Grupo de Teatro TIC-TAC da Faculdade de Ciências da Universidade do Porto

Encenação: Tó Maia

$1^{\text {a }}$ Apresentação: Porto, Teatro Latino

Data: 22. 4. 2002

Outras: 23. 4. 2002. 
A peça foi levada ao palco no âmbito da primeira edição da iniciativa Pó de Talco - Festival de Teatro Universitário, que decorreu no Porto entre 19 e 24 de Abril de 2002. Para além desta foram representadas outras peças, por grupos amadores da Universidade do Porto. A iniciativa contou também com debates e tertúlias culturais organizados em espaços diversificados da cidade.

Maria do Céu Fialho

Carlo Emilio Gadda, Eros e Priapo

Produção: Instituto Italiano de Cultura em Portugal

Encenação: Adriana Martino

1. ${ }^{a}$ Apresentação: Teatro do Salitre - Instituto Italiano de Cultura em Portugal Data: 17. 5. 2001.

Logo após a libertação de Florença, Carlo Emílio Gadda começou, nos anos 1945 e 1946, a trabalhar em Eros e Priapo. Simultaneamente, redigia Pasticciaccio brutto di via Merulana. Queria dar voz à sua revolta contra vinte anos de fascismo, embora, a princípio, o tenha acolhido com alguma simpatia. Dedicou-se a outros afazeres e, em 1955, retomou o trabalho então abandonado, que acabou por publicar, em edição de Garzanti, de 1967.

Baseada no pressuposto de que o panfleto revolucionário de Gadda devia ser uma obra de referência nas leituras de um citadino italiano familiarizado com a arte do seu tempo, Adriana Martino encenou Eros e Priapo, que o próprio autor definiu como «libello psicanalitico, diviso tra arringa e memoriale narrativo» e um «atto di conoscenza» de um tempo de domínio, na Itália, «d'un cupo e scempio Eros sui motivi di Logos».

Da confluência de Eros, deus do amor e símbolo da amizade e da harmonia, com Priapo, deus do instinto sexual e da virilidade masculina, resultam necessariamente monstros. $\mathrm{O}$ tema do fascismo é o ponto de partida para um jogo de invenção, movimento, interpretação, insinuação, aprofundamento, inversão, ampliação, deformação, em vertiginoso borbulhar de palavras e imagens, que acaba por alterar, de forma profunda, a realidade que rodeia Gabba. A polémica é devastadora, furiosa e quase incontrolada. A lembrança das relações amorosas do Duce levava Gadda a odiar os chefes fascistas e alguma misoginia estendia esse ódio às amantes de Mussolini e de seus sequazes. Tal é o mimetismo da língua de Gadda, que dá vida a páginas de extraordinária literatura.

Elenco: Intérprete do Monólogo - Valentina Martino Ghiglia; À Percussão - Andrea Nicolé; Elementos Cénicos - Anna Aglietto; Consulenza Musicale - Benedetto Ghiglia. 
Platão, Fédon

Produção: As Boas Raparigas

Encenação: Rogério de Carvalho (nova encenação)

$1^{\text {a }}$ Apresentação: Porto, Estúdio Zero

Data: 9. 10 - 19. 10. 2003.

Muito discreto na sua concepção, o espectáculo mais parece um simples enquadramento para um texto de leitura densa, onde a imortalidade da alma é motivo central. E nem mesmo a qualidade das actrizes e a sua dicção pausada conseguem diluir o peso e a extensão de um projecto teatral de difícil execução cénica. Esta é uma segunda encenação que as Boas Raparigas fazem do texto de Platão.

Elenco: Actores - Carla Miranda, Maria do Céu Ribeiro.

M. F. S. S.

\section{Guerreiros Miticos. Os Guardiães da Lenda} Apresentação: RTP1

No Canal 1 da RTP passaram duas séries de desenhos animados baseados nas lendas de alguns dos heróis mais conhecidos do Mundo Antigo greco-romano. Ao sábado, inserida no programa Clube Disney, passa uma série produzida por esse gigante americano, que tem por protagonista Hércules. $\mathrm{Na}$ sequência do filme apresentado anteriormente nas salas de cinema, tendo por título o nome desse super-herói da antiga Grécia, os estúdios da Disney desenvolveram uma série de episódios, cuja principal característica consiste em adaptar a realidade do mito ao universo actual. A título exemplificativo observamos apenas que o filho de Zeus tanto aparece a defrontar os tradicionais perigos, como, em flagrante anacronia, disputa um jogo de bowling ou vê-se rodeado por bailarinas de um verdadeiro número de musical à moda de Hollywood. Aos domingos de manhã surge outra série, mais abrangente do ponto de vista das figuras e das fábulas, denominada Guerreiros míticos. Os Guardiães da Lenda. Resultado de uma co-produção de três países (Canadá, França e China), o conjunto de episódios versa os mais diversos mitos, como as aventuras de Cadmo e de sua irmã Europa, dos gémeos Castor e Pólux, os amores de Eros e Psique, a viagem de Jasão e dos Argonautas em busca do velo de ouro, os doze trabalhos de Hércules e a explicação da sucessão das estações do ano através da história de Perséfone, filha de Deméter. Se excluirmos algumas imprecisões, normais em releituras e que sempre acabam por ocorrer, o denominador comum a todos estes 
contos é o seu sentido ético. Há sempre uma moral da história, destinada a exaltar valores, de que são exemplo a coragem, a dedicação, a persistência e a entre-ajuda, subjacentes a boa parte das lendas inventariadas.

Carmen Leal Soares

\section{Helena de Tróia}

Produção: EUA/Lt. (1956)

Projecção: TVI

Data: 31. 1. 2004.

Elenco: Actores - Rossana Podestà, Jacques Sernas, Cedric Hardwicke, Stanley Baker.

M. F. S. S.

\section{Mozart, Idomeneo, Re di Creta}

Produção: Coro e Orquestra da Ópera de Mannheim

Direcção Musical: Adam Fischer

$1^{a}$ Apresentação: Santa Maria da Feira, Grande Auditório do Europarque

Data: 6. 4. 2002.

O Coro e a Orquestra da Ópera de Mannheim apresentaram, em versão de concerto, a ópera Idomeneo, Re di Creta de Mozart, em Santa Maria da Feira. Inserida no ciclo "Grandes Orquestras Mundiais", esta ópera contou com o apoio da Fundação Calouste Gulbenkian e da Casa da Música.

Elenco: Intérpretes (Solistas) - Christian Elsner, Andrea Szántó, Lothar Odinius e Ludmila Slepniowa.

Susana Hora Marques

\section{Mozart, Idomeneo, Re di Creta}

Produção: Estúdio de Ópera da Casa da Música do Porto

$1^{a}$ Apresentação: Porto, Casa das Artes

Data: 16. 11. 2002.

O Estúdio de Ópera da Casa da Música, herança da Porto 2001 - Capital Europeia da Cultura, apresentou "O essencial de Mozart" numa das suas sessões de recitais mensais na Casa das Artes. Do programa constavam, além de excertos de Idomeneo, Cosi fan Tutte e As Bodas de Fígaro de Mozart, um excerto de L'Incoronazione di Poppea de Monteverdi, uma ária da Rusalka de Dvorák e duas árias de Albert Herring de Britten. 
É objectivo deste Estúdio de Ópera formar jovens cantores, cujos resultados do trabalho são exibidos em recitais como este.

Elenco: Cantores - Liliana Coelho, Luísa Barriga, Eduarda Melo, Magna Ferreira, Alexandra Moura, Ricardo Ceitil, Hugo Oliveira, Rui Baeta; Pianista - Rui Pinheiro.

Susana Hora Marques

W. A. Mozart, Idomeneo (Abertura e os dois primeiros números da Música de Bailado)

$1^{\text {a }}$ Apresentação: Lisboa, Teatro Municipal São Luiz

Iniciativa: Teatro Nacional de São Carlos / Teatro Municipal São Luiz

Data: 10. 10. 2003.

No âmbito do programa 'Cinco Pianistas Portugueses para os Cinco Concertos de Beethoven', promovido em parceria pelo Teatro Nacional de São Carlos, pelo Teatro Municipal São Luiz, em colaboração com a Câmara Municipal de Setúbal no plano das comemorações dos 250 anos do nascimento de Luisa Todi, realizou-se um concerto onde foi executada a abertura e os dois primeiros números da Música de Bailado de Idomeneo de Mozart. A execução musical coube à Orquestra Sinfónica Portuguesa do TNSC e a direcção musical ao Maestro Roberto Pollastri. Participaram ainda o pianista António Rosado, o clarinete Francisco Ribeiro e a soprano Teresa Cardoso de Menezes.

M. F. S. S.

Pietro Babina, Iliade, adaptação de Homero

Produção: Teatrino Clandestino

Encenação: Pietro Babina

Iniciativa: Semana Internacional do Teatro (Coimbra Capital Nacional da

Cultura)

$1^{\text {a }}$ Apresentação: Coimbra, TAGV

Data: 13-14. 5. 2003.

Outras: Porto (Teatro Nacional de S. João), 17-18. 5. 2003.

Esta representação, inspirada em Homero, recorre a video, multimédia e música. $\mathrm{O}$ cenário comporta dois planos, um superior, em video, onde agem as divindades, outro inferior ocupado pelos homens ao vivo. Os efeitos sonoros e visuais animam os temas homéricos com o silvo dos dardos de guerra e com o rumor do mar. De resto, a exploração das 
potencialidades multimedia no teatro é uma prioridade para o Teatro Clandestino.

Elenco: Actores - Alessandro Cafiso, Davide Garagnani, Massimiliano Martines, Mauro Milone, Andrea Mochi Sismondi, Manfredi Siragusa, Fiorenza Menni (Capocomicato), Lola Sofia Duve (Voz da Deusa), Enrico Mariottino (Voz do Poeta e do Deus); Cenografia - Pietro Babina, Giovanni Brunetto, Diego Garbini; Figurinos - Fiorenza Menni; Live Multimedia - Nicola Zonca; Desenho de Som - Alessandro Saviozzi; Música - Pietro Babina.

M. F. S. S.

\section{Mitos clássicos na poesia portuguesa contemporânea}

Produção: Teatro Clássico de Conimbriga (TCC) e Liga dos Amigos de Conimbriga (LAC)

Encenação e Dramaturgia: José Geraldo

Iniciativa: Encontros de Teatro de Tema Clássico

$1^{a}$ Apresentação: Coimbra, Pátio da Universidade

Data: Conimbriga, 23-24. 4. 2001

Outras: Viseu (Universidade Católica), 24, 26. 4. 2001; Nelas (Quinta da Cerca), 23. 6. 2001; Sintra (Museu Arqueológico de Odrinhas), 29. 6. 2001; Parque Arqueológico do Vale do Côa, 21.7. 2001; Conimbriga, 16. 4. 2002.

Ver Vol. II, pp. 214-216.

Luísa de Nazaré Ferreira

\section{Vangelis, Mythodea}

Produção: Coro da Ópera Nacional da Grécia e Orquestra Metropolitana de Londres

Realização: Declan Lowney

Transmissão: RTP 2 (Artes de Palco)

Data: 23. 2. 2002.

Inspirado em temas da mitologia grega, Vangelis compôs esta Mythodea, que serviu de tema musical para uma missão da NASA, «2001, Odisseia em Marte». Esta apresentação, feita num concerto ao vivo, em Atenas, junto ao templo de Zeus, foi encenada de modo a que se projectassem no espaço, ao mesmo tempo que se interpretava a partitura, imagens da missão espacial alternadas com iconografias da mitologia clássica. Esta apresentação teve a participação especial dos sopranos Jessye Norman e Kathleen Battle, que foram acompanhados por 120 membros do 
Coro da Ópera Nacional da Grécia e pela Orquestra Metropolitana de Londres.

Nuno S. Rodrigues

Friedrich Hölderlin, A morte de Empédocles

Produção: Teatro da Cornucópia

Encenação: Luís Miguel Cintra

Tradução: Maria Teresa Dias Furtado

1. ${ }^{\mathrm{a}}$ Apresentação: Teatro do Bairro Alto

Data: 1.3.2001

Outras: Lisboa (Teatro do Bairro Alto), 1.3 - 1. 4. 2001, de $3{ }^{\mathrm{a}}$ a Domingo.

Entre 1797 e 1799 escreveu Friedrich Hölderlin

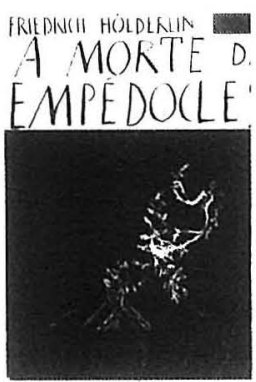
três versões de $A$ morte de Empédocles e todas deixou inacabadas: sete eram os actos previstos. As três versões baseiam-se em concepções distintas e todas, de algum modo, se complementam. Há, aos olhos de Hölderlin, certas semelhanças entre o momento histórico que ele próprio está a viver e a Agrigento do séc. V a.C., terra natal de Empédocles. A Alemanha do seu tempo oscila entre uma adesão aos ideais revolucionários franceses de 1789 igualdade, liberdade e fraternidade -, e a manutenção da ordem política e social tradicional.

Em virtude de a França ter acabado por não apoiar os jacobinos alemães, a revolução cultural deslocou-se para um plano utópico. A Grécia simbolizava, para o Hölderlin do "Fundamento de Empédocles", a contraposição harmónica ou reconciliação entre arte e natureza, entre beleza e verdade, entre homens e deuses, entre informe e ilimitado, por um lado, e o que é dotado de forma e de limites, por outro. Era a recordação longínqua de uma regra há muito abolida na terra. Cristão, panteísta e adepto incondicional dos ideais revolucionários, procurou, na sua escrita de pendor clássico e na cultura grega, a natureza e os ideais de harmonia, beleza e unidade. Mas Agrigento é o princípio do fim de um sonho de harmonia entre as leis humanas da cidade-estado e as do cosmos e o início de uma oposição entre arte e natureza, e, nessa medida, a cidade grega é uma metáfora da modernidade. Resta saber se a consciência moderna, absorta em intermináveis reflexões incompatíveis com o equilíbrio clássico da forma, ainda pode ressuscitar essa harmonia inicial.

Empédocles é o ponto de charneira entre a harmonia e o caos. Era um filósofo pré-socrático que, na sua cosmogonia, concebia os quatro elementos como divindades e sujeitos a constante transformação e a relações marcadas por uma dialéctica de opostos. Perante a dissolução das instituições e a revolta do povo de Agrigento, Empédocles, idealista, visionário, filósofo, 
vidente, sacerdote e poeta, procurou conduzir os seus conterrâneos no progressivo conhecimento da natureza. O problema é que o pré-socrático, mercê do seu carácter insatisfeito e do ódio que começou a nutrir pela cultura - resultante, de resto, de uma disposição anímica e da sua concepção filosófica, como testemunha o "Plano de Francoforte" -, perdeu a noção de equilíbrio que devia sustentar tal propósito e desejou ser um deus para abarcar toda a natureza, e estar em grandiosa e uníssona comunhão com tudo o que o rodeava. $\mathrm{O}$ resultado foi a expulsão da sua cidade e a busca de uma condição divina que a matéria de que era constituído e a sua inquebrável ligação ao tempo peremptoriamente lhe negaram. Sobreveio a solidão e o suicídio consumou, de forma trágica, a união de Empédocles com a natureza: lançou-se na cratera do Etna. É a morte que dá sentido à existência do herói trágico, como o próprio Holderlin confessa numa carta dirigida a seu irmão e datada de junho de 1999. Empédocles passava da felicidade à desgraça e era vítima do seu conhecimento e da sua virtude.

Hölderlin quis uma tragédia "segundo os ideais do teatro grego" e Maria Teresa Dias Furtado traduziu as versões de $A$ morte de Empédocles que estão na base do espectáculo.

Entre as modernas actualizações de referência de $A$ morte de Empédocles contam-se uma produção dos anos 70, pela Schaubuhne am Halleschen Ufer de Berlim, sob a direcção de Klaus-Michael Gruber, com o notável desempenho de Bruno Ganz, e ainda o filme de Jean-Marie Straub e Danielle Huillet, de 1986 (Cf. Representações de teatro clássico no Portugal contemporâneo, vol. II, 218).

Quando confrontado com a possibilidade de encenar as três versões de A morte de Empédocles, Luís Miguel Cintra diz-nos: «Concluí que era praticamente impossível porque cada versão tem um carácter diferente. $\mathrm{Na}$ última, Empédocles já não sofre e as hesitações desapareceram. Achei que seria mais interessante e mais teatro para nós apanhar o momento da hesitação e da passagem à decisão da morte.» (apud Cristina Peres, "O poder da natureza," Expresso, Cartaz, 24.2.2001). Esta nova produção da Cornucópia surgiu depois de Afabulação, de Pasolini, e precedeu o $D$. João e Fausto, de Grabbe, e $O$ Novo Menosa ou a História do Príncipe Tandi, de Lenze.

Fiel ao espírito do conjunto da obra de Hölderlin, A morte de Empédocles, genuíno "drama sacro", além de questionar a importância de valores como a igualdade, a liberdade e a fraternidade na vida humana, busca uma conciliação entre paganismo helénico e cristianismo à luz de experiências vivenciais como a solidão, a incompreensão, o isolamento e o sacrifício. Ao falhar no projecto redentor para si e para a sua sociedade, Empédocles é punido no seu crime do mesmo modo que o próprio Hölderlin se torna vítima da loucura. Segundo Wilhelm Dilthey: «O destino trágico não consiste aqui numa relação externa entre a culpa e o castigo decretados pela ordem divina, senão na conexão causal que se deve à interacção das forças 
humanas.» (apud Jorge Henrique Bastos, "Profético e visionário," Expresso, Cartaz, 24 . 2 . 2001).

O que, no texto de Hölderlin, atrai Luís Miguel Cintra é, nas suas próprias palavras, «a fé numa utopia que é de uma tal pureza que já não estamos habituados a conceber que tenha existido e muito menos que possa ainda existir na cabeça de alguém» (apud Cristina Peres, "O poder da natureza," cit.). Depois de conduzir o seu povo, Empédocles sacrifica-se por um futuro sem chefes e onde o povo possa evoluir nas suas contradições. Segundo Cintra, trata-se de um "elogio da humildade" (apud Cristina Peres, "O poder da natureza," cit.) e de uma crença no próprio homem, independentemente de qualquer ideia de poder.

Ao falar do processo de criação do espectáculo, confessava Luís Miguel Cintra que tinha crescido de estar em palco, do «saber quais são as tensões de sentido que se geram no texto para fazer o sentido fluir sempre entre umas personagens e outras» (apud Cristina Peres, "O poder da natureza," cit.).

A música tem, neste espectáculo um lugar de destaque, já que Nuno Vieira de Almeida acompanha os dois actos com excertos das últimas sonatas de Schubert, em clara sugestão da cumplicidade e independência de dois génios criadores como Schubert e Hölderlin. Há, de algum modo, uma unidade poética nesta espécie de musical mascarado pelo próprio texto, na medida em que a música, a palavra e o gesto se enriquecem e se iluminam.

Ao fundo do palco, vê-se um universo de cores que vai do violeta ao amarelo, passando pelo azul. O branco do chão continua pelas paredes laterais, e é acentuado por riscos azuis, cinzentos e verdes, cores que encontramos na natureza da Sicília e de outros lugares. Deste espaço diz Cristina Peres que «retoma a situação de um dispositivo cénico que é capaz de conter a impossibilidade de traduzir os conceitos expressos no texto" ("O poder da Natureza", cit.). Carlos Porto considera que a simplicidade e a beleza do cenário suscitam desde logo a adesão do espectador, e que o desenho de um dos fatos de João Grosso não é o mais feliz ("Memórias de Hölderlin," $J L, 21$. 3 . 2001, 24).

Os actores, no geral, foram capazes de transmitir as subtilezas do texto: Luís Miguel Cintra foi um Empédocles absolutamente notável. Quanto a personagens como o discípulo Pausânias, a seguidora Panthea, e Délia, ao observarem o drama, o espectáculo e as questões, parecem contribuir para um enquadramento que nada tem de decorativo ou de secundário. Rita Loureiro e Ricardo Aibéo são eloquentes na sua correcção e no seu empenho, mas Sofia Marques revela alguma insegurança. Luís Lima Barreto é mais discreto na sua aproximação às questões centrais, e João Grosso, mais veemente. José Manuel Mendes foi o grande interlocutor de Empédocles.

A crítica foi tão elogiosa em relação a esta produção que, se Carlos Porto elogiou a «beleza da cenografia tão bem definida pela luz, o rigor da encenação e do trabalho de actores» (Carlos Porto, "Memórias de Hölderlin," 
$J L$, 21.3.2001, 24), já João Carneiro falou de um «belíssimo espectáculo que reúne a emoção e o gosto por um grande texto literário que é também um grande texto de problematização filosófica, e uma modalidade de distanciamento que se quadra especialmente bem com esta revisitação romântica de antigas personagens e de antigos problemas. Esta atitude acaba por ter um efeito muito próximo do teatro dentro do teatro, permitindo-nos, a nós, hoje, perspectivar questões que não perderam um átomo da sua pertinência.» ("O divino humano," Expresso, 17 . 3 . 2001).

Elenco: Actores - João Grosso, José Manuel Mendes (Hermócrates), Luís Miguel Cintra (Empédocles), Luís Lima Barreto, Ricardo Aibéo (Pausânias), Rita Loureiro, Sofia Marques; Pianista - Nuno Vieira de Almeida; Cenário e Figurinos - Cristina Reis; Desenho de Luzes Daniel Worm d'Assumpção.

Paulo Sérgio Ferreira

\section{Orféo}

Produção: Michel Lemieux e Victor Pilon, com a colaboração de Ginette Prévost $1^{\text {a }}$ Apresentação: Lisboa, CCB

Data: 10-12.5. 2001.

Espectáculo a quatro dimensões apresentado pela primeira vez no Canadá, em Montreal (1998) - da responsabilidade de Michel Lemieux e Victor Pilon, em colaboração com Ginette Prévost - Orféo esteve no Centro Cultural de Belém nos dias 10 a 12 de maio de 2001. Tenta seduzir o público pelas imagens oníricas e cativá-lo através de efeitos especiais e de

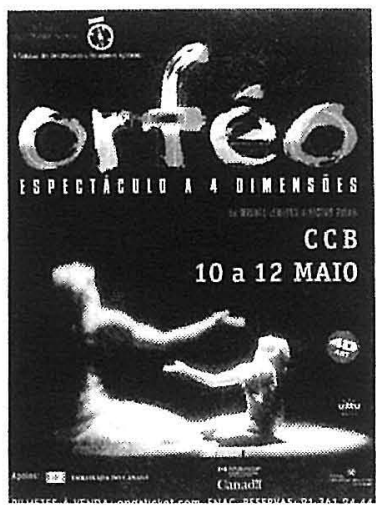
constantes transformações de cenário.

É conhecido o mito de Orfeu que, desgostoso com a morte da mulher amada, consegue a permissão do retorno de Eurídice à luz do dia, com a condição de a não olhar, promessa que não foi capaz de cumprir. Esta história de amor profundo e de luta contra a morte é, no Orféo de Lemieux e Pilon, transformada, de modo a adaptá-la ao mundo moderno. Orfeu, interpretado por Michel Laprise, é um pacifista; Eurídice, uma investigadora num programa diário de rádio recriada por Julie Slater, perde a vida num acidente. Orfeu entra em depressão e afoga as mágoas no álcool. E assim, consumido pela dor, empreende uma viagem imaginária, onírica, em que os desejos 
íntimos se sobrepõem aos receios e à dura realidade: em estado de delírio procura a sua amada perdida num labirinto / Hades, um mundo de trevas e sombras, do qual nunca ou quase nunca se escapa. Aí Orfeu ouve o chamamento de Heurtebise, uma personagem cínica que não pode ser considerada boa ou má, nem anjo nem demónio. Servidor da Morte, desde que perdera a vida por suicídio, é uma espécie de guia que desestabiliza, junta, separa, destrói.

Ao acordar no Hades, Eurídice relembra a vida passada e recusa aceitar a morte. Heurtebise, seu guia, vê nela uma oportunidade de voltar ao reino dos vivos e descobrir o que tanto a atrai. E assim no contacto com Orfeu e Eurídice, nos quais o Amor se tornara mais poderoso do que a Morte, ele descobre o significado e força da Vida.

Espectáculo multimédia, que combina de forma apropriada elementos próprios da área do cinema, do vídeo, do teatro, da música, da dança, Orféo tornou-se um verdadeiro laboratório experimental e de criatividade, no qual a tecnologia avançada foi colocada ao serviço da valorização do actor e do texto, afinal os elementos fundamentais do drama.

Michel Lemieux e Victor Pilon procuraram provocar no espectador e conseguiram-no - um mundo de ilusão, com papel de relevo para o holograma, em que os actores / bailarinos evoluem entre imagens virtuais.

Elenco: Intérpretes - Michel Laprise (Orfeu), Julie Slater (Eurídice), Peter James (Heurtebise); Música - Michel Lemieux; Cenografia - Victor Pilon, Michel Lemieux, Gabriel Tsampalieros; Projeç̧ões Virtuais - Michel Lemieux; Projecções no Palco - Victor Pilon; Desenho de Luz - Axel Morgenthaler, Alain Lortie; Figurinos - Gabriel Tsampalieros, Carole Courtois; Figurantes Virtuais - Véronique Bosset, Patrice Ellie, Silvye Garbusky, Ivan Gareau, Alain Girard, Joan Levasseur, Caroline Niquette, Paquette, Victor Pilon, Ginette Prévost, William Proteau, Charles-Antoine Trottier, Lola Trattier, Alice Veevaete, Bérubé.

José Ribeiro Ferreira

Ch. W. Gluck, Orfeo ed Euridice (Libreto de Ranieri De' Calzabigi)

Produção: Grupo Conservatório de Música de Coimbra

Iniciativa: FESTEA, integrado no III Festival Escolar de Teatro de Tema Clássico

$1^{\text {a }}$ Apresentação: Coimbra, Museu Machado de Castro

Data: 23. 4. 2001

Outras: Conimbriga, 18. 5. 2001. 
Numa clareira de um bosque solitário, calmo e ameno, encontra-se o túmulo de Eurídice. Orfeu chora a morte da sua amada; Pastores e Ninfas acompanham a sua dor.

Surge Amor que transmite uma mensagem de esperança. Orfeu terá que resgatar a sua amada... Orfeu enfrenta as fúrias e os espectros acalmando-os com o som doce da sua lira. Na cena seguinte, Eurídice, acompanhada dos Heróis e Heroínas, contempla o espaço celeste. Orfeu encontra esse espaço e Eurídice segue-o com o olhar.

Orfeu conduz Eurídice pela mão sem a olhar. Zangada por não entender a atitude do amado, afasta-se. Num acto de volúpia, Eurídice força Orfeu a olhá-la. Quando tal acontece, ela cai morta. Orfeu chora e recusa viver. Surge então Amor que evita a morte de Orfeu e, reconhecendo a sua infindável dedicação, desperta Eurídice para a vida. Amor, Orfeu e Eurídice, seguidos dos heróis e heroínas, festejam a vida...

Com encenação e direcção artística de Isabel Melo e Silva, com direcção do Coro de Isilda Margarida e com Júlio Dias ao piano, Orfeo ed Euridice constituiu um espectáculo feliz e agradável que encontrou cenário condigno, quer na Igreja de S. João de Almedina (Museu Nacional Machado de Castro), quer na Casa dos Repuxos de Conimbriga. Distingo o bem conseguido desempenho da figura de Orfeu por qualquer dos três intérpretes, Eduardo Alves, José Paulo Almeida e Luís Filipe Toscano (um em cada acto); bem como a de Eurídice, tanto por Ana Catarina Reis como por Catarina Braga. Também não destoaram, na interpretação da figura de Amor, Catarina Depraetere Sereno e Raquel Luís.

Coro: Ana Carina Reis, Ana Filipa Lopes, Ana Sofia Gonçalves, Carla Alexandra Pires, Eva Paula Pimenta, Isabel Maria Furtado, Mónica Baptista e Maria Dulce Freitas (Sopranos); Catarina Depraetere Sereno, Carlos Manuel Pocinho, Catarina Braga, Raquel Luís e Oriana Cardoso (Contraltos); Eduardo Alves, José Paulo Almeida, Luís Filipe Toscano, Marta Isabel Osório e Rui André Previdência (Tenores); Carlos Filipe Cruz, David Oliveira, Francisco Miguel Silvestre, Henrique Sérgio Guerra, Jorge Marinheiro, Mário Miguel Morais, Nuno Miguel Araújo, Paulo Pereira e Pedro Figueiredo (Baixos).

José Ribeiro Ferreira

Ch. W. Gluck, Orfeo ed Euridice (Libreto: Ranieri de Calzabigi)

Produção: Companhia do Teatro Nacional de S. Carlos

Orquestra: Orquestra Sinfónica Portuguesa

Direcção Musical: Arnold Oestman

Temporada: S. Carlos 2002-2003

$1^{\text {a }}$ Apresentação: Teatro Nacional de S. Carlos

Data: 19, 21 e 23. 12. 2002. 
No ano seguinte, a ópera de Ch. W. Gluck, com libreto de Ranieri de Calzabigi, fez parte da temporada do Teatro Nacional de S. Carlos, nos dias 19,21 e 23 de dezembro, com direcção musical de Arnold Oestman e execução da Orquestra Sinfónica Portuguesa e do Coro do Teatro Nacional de S. Carlos.

A contralto italiana Bernardette Manca di Nissa - cujo desempenho em Orfeo ed Euridice já merecera, em 1989, o Prémio Abbiati, atribuído pela crítica internacional à melhor interpretação feminina - voltou a demonstrar as suas grandes capacidades vocais e interpretativas, e, segundo Fernando Pires (DN Domingo de 29. 12. 2002, p. 33), deu-nos uma criação de Orfeu de grande nível, «para recordar», que nos fez sentir e viver a dor do mítico cantor, partilhando «o desespero de Che faro senza Euridice, cantado com verdade interior», e que foi muito aplaudido.

Elenco: Intérpretes - Bernadette Manca di Nissa (Orfeu), Ana Ferraz (Amor), Carmela Remígio (Eurídice); Coro - Teatro Nacional de S. Carlos (maestro titular - João Paulo Santos).

José Ribeiro Ferreira

\section{J. Offenbach, Orfeu no Inferno \\ Produção: Ópera Nacional de Lyon \\ Programação televisiva MEZZO \\ Data: Abril de 2003.}

No Expresso, dentro da programação dedicada à TV, anunciava-se: 'Orfeu no Inferno é uma paródia à antiga fábula. Aqui, Orfeu é um mau tipo que detesta a mulher, Eurídice. Uma produção da Ópera Nacional de Lyon, com Yann Beuron e Nathalie Dessay'.

M. F. S. S.

Ch. Gluck, Paride ed Elena (Ópera em 5 actos para solistas, coro e orquestra)

Libretto: Ranieri de Calzabigi

Director de Orquestra: Paul McCreesh

Orquestra: Gabrieli Consort \& Players

Iniciativa: VII Concertos Portugal Telecom 'Em Órbita'

$1^{\text {a }}$ Apresentação: Grande Auditório do CCB

Data: 25. 10. 2003

Outras: Porto (Rivoli Teatro Municipal), 29. 11. 2003. 
Esta ópera (1770), apresentada em versão de concerto pelos Gabrieli Consort \& Players, dirigidos por Paul McCreesh, retoma o tema dos amores de Páris e de Helena. Os solistas foram acompanhados por um coro de 18 cantores e por uma orquestra de 38 instrumentistas. Em subtítulo, esta ópera, apresentada em Viena no ano da sua composição, designa-se por Amor uincit omnia e desenvolve, em cinco actos, um processo de sedução e de conquista gradual por parte de Páris face à resistência de Helena, uma resistência que advém da diferença de temperamentos, de cultura e de modo de vida.

Elenco: Solistas - Magdalena Kozena, meio-soprano (Páris), Claron McFadden, soprano (Helena), Carolyn Sampson, soprano (Amor), Gillian Webster, soprano (Palas), Daniel Auchincloss, tenor (Um Troiano).

M. F. S. S.

\section{J. Sousa Carvalho, Penélope}

Produção: Orquestra Filarmonia das Beiras

Maestro Director: Augusto Mesquita

$1^{a}$ Apresentação: Coimbra, Capela de S. Miguel (Universidade de Coimbra)

Data: 19. 10. 2001.

No âmbito do programa com que a Universidade de Coimbra deu início ao Ano Cultural 2001-2002, a Orquestra Filarmonia das Beiras executou, na Capela da Universidade de Coimbra, um concerto de cujo programa fazia parte a Abertura de Penélope de J. Sousa Carvalho (1782). Este texto corresponde ao manuscrito 48-I-44, da Biblioteca da Ajuda II vol.: Manuscrito autógrafo da Biblioteca Geral da Universidade de Coimbra.

M.F.S.S.

\section{James Dillon, Philomela}

Produção: Remix Ensemble

$1^{\text {a }}$ Apresentação: Porto, Casa da Música

Data: 2004.

rock.

O escocês James Dillon é figura conhecida na música tradicional e no

M. F. S. S. 


\title{
Andrea Gabilondo, $A$ Porta Aberta
}

Produção: Associação Cultural La Marmita, em colaboração com o Pé de Vento

$1^{\text {a }}$ Apresentação: Porto, Teatro da Vilarinha

Data: 15-30. 11. 2002.

O mito das Parcas foi motivo inspirador da bailarina e coreógrafa Andrea Gabilondo no espectáculo de dança "A Porta Aberta". Evocando locais e situações diferentes com os seus movimentos, a dançarina tentou seguir o fio tecido por Átropo, Cloto e Láquesis. E, como sublinha Ana Cristina Pereira no Jornal Público de 15 de Novembro de 2002, «...nesta espécie de labirinto sonhado, procura uma porta aberta: o destino. Como que a alertar para as limitações do ser humano, incapaz de decidir o pleno rumo da sua vida. Como que a sublinhar o quão apaixonante é viver, apesar dos momentos em que nada parece ter sentido».

Elenco: Bailarina - Andrea Gabilondo; Coreógrafa - Andrea Gabilondo.

Susana Hora Marques

\section{Monteverdi, $\boldsymbol{O}$ regresso de Ulisses à Pátria \\ Produção: Orquestra Filarmónica de Londres \\ Direcção: Raymond Leppard \\ Data: 8. 6. 2002.}

Este espectáculo passou na televisão, na versão gravada em Glyndebourne e dirigida por Raymond Leppard, à frente da Orquestra Filarmónica de Londres, com Benjamin Luxon no papel de Ulisses.

D. F. Leão

\author{
António Pinho Vargas, Il Ritorno \\ Executante: Ana Mafalda Castro \\ Iniciativa: IV Festival Internacional de Música de Mafra \\ $1^{\text {a }}$ Apresentação: Palácio Nacional de Mafra
}

Data: 27. 10. 2002.

Peça para cravo barroco, Il Ritorno foi composta por António Pinho Vargas para a sua esposa, Ana Mafalda Castro. Ao Diário de Notícias de 23.1.2003 ("Professora por natureza", Maria João Caetano), a reputada cravista revelou que este tinha sido o recital mais importante da sua carreira. 
Se o título da obra evoca, em primeiro lugar, a ópera Il Ritorno di Ulisse in patria, de Monteverdi, ao "Cartaz" do Expresso de 26.10.2002 o compositor esclareceu que a essência da peça reside nas "intuições de Kavafis no poema 'Ítaca': "A Odisseia relata o regresso de Ulisses à pátria. Mas Kavafis acentua a necessidade de viver intensamente cada frase dessa viagem enquanto processo."

Luísa de Nazaré Ferreira

\section{L. van Beethoven, Die Ruinen von Athen (Abertura)}

Iniciativa: Teatro Nacional de São Carlos / Teatro Municipal São Luiz / Câmara Municipal de Setúbal

$1^{\text {a }}$ Apresentação: Setúbal, Forum Municipal Luisa Todi

Data: 30. 9. 2003

Outras: Lisboa (Teatro Municipal São Luiz), 1. 10. 2003.

No âmbito do programa 'Cinco Pianistas Portugueses para os Cinco Concertos de Beethoven', promovido em parceria pelo Teatro Nacional de São Carlos, pelo Teatro Municipal São Luiz, em colaboração com a Câmara Municipal de Setúbal no plano das comemorações dos 250 anos do nascimento de Luisa Todi, realizou-se um concerto onde foi executada a abertura de Die Ruinen von Athen de Beethoven (cena e ária para soprano e orquestra). A execução musical coube à Orquestra Sinfónica Portuguesa do TNSC e a direcção musical ao Maestro Riccardo Frizza. Participou a soprano Elisabete Matos.

M. F. S. S.

Ser e não ser ou estórias da História do Teatro Produção: A Barraca

Encenação: Maria do Céu Guerra

$1^{\text {a }}$ Apresentação: Teatro Cinearte- A Barraca

Data: 22. 5. 2004.

O objectivo deste espectáculo foi o de transpor para o palco uma espécie de pequena História do Teatro, através dos seus momentos mais significativos. Para isso, a sua autora, a actriz Maria do Céu Guerra, recorreu a textos de Ésquilo, Sófocles, Eurípides, Aristófanes, Plauto, Angelo

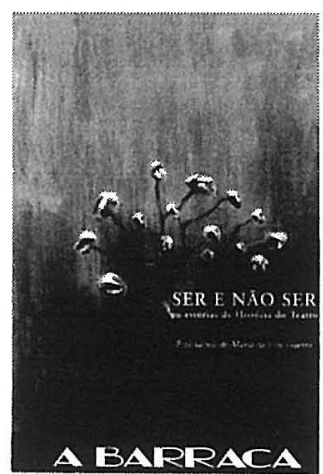
Beolco, Gil Vicente, Shakespeare, Christopher Marlowe, Miguel de 
Cervantes, Benavente, Agustin Rojas, Cálderon de la Barca, Molière, Corneille, Goldoni, Dumas Filho, Ibsen, Tchekov, Stanislavsky, Brecht e Arthur Miller. A inclusão deste espectáculo neste catálogo justifica-se pela representação de passos e cenas dos clássicos greco-latinos. À semelhança do que acontece com os textos mais modernos, foram escolhidos para protagonizarem esta História de estórias figuras-chaves do teatro antigo: Prometeu, Édipo, Jocasta, para a tragédia; Lisístrata e Sósia, para a comédia. O coro foi representado pelo das Bacantes. Estranhamos, apesar de compreendermos a impossibilidade de recorrer a todas as figuras, a ausência de Antígona, figura estruturante e recorrente na História do Teatro em geral.

Assim, ainda que não se trate de um texto dramático, o texto desta História do Teatro inclui passos da Ilíada, tendo sido, porém, utilizada uma tradução feita a partir do francês. Do mesmo modo, não se recorreu a traduções feitas do grego original para os passos seleccionados de $A s$ Bacantes de Eurípides. Pelo contrário, o texto de Sófocles utilizado para a composição deste mosaico é o da versão portuguesa de Maria do Céu Zambujo Fialho, reconhecida helenista. Mas inserem-se ainda passos do Prometeu, de Ésquilo (numa tradução de E. Scarlati), da Lisistrata, de Aristófanes (numa tradução de M.J. Gomes), do Anfitrião de Plauto (numa tradução de Agostinho da Silva). Escolheram-se estas traduções, apesar de todos estes textos estarem vertidos para português em versões mais actualizadas, pela mão de reconhecidos helenistas e latinistas nacionais. Eurípides é ainda representado através de um fragmento traduzido por Jorge de Sena.

A estes textos, que grosso modo compõem aquilo que a sua Autora decidiu classificar como a I Parte do espectáculo, junta-se ainda um passo de Shakespeare, na II Parte, que trata a figura da princesa Dido de Cartago (acto IV, cena VI, em tradução de Guilherme Mendonça).

O espectáculo pôde ser visto seguido ou por actos, utilizando para o efeito o mesmo bilhete e desde que marcado no prazo de uma semana. Este foi um dos pontos de grande originalidade da produção.

Elenco: Actores - Pedro Borges (Prometeu, Édipo, Hamlet), Maria do Céu Guerra (Jocasta, Ranevskaya-Liouba), Margarida Miranda (Lisistrata, Dido), Sérgio Moras (Sósia, Scaramouche), Pedro Diogo (Arlequim), Luís Thomar (Falstaff, Macbeth, Lopakhine), Gil Filipe (Ricardo II), Carla Alves (Lady Macbeth), João d'Ávila (Próspero), Mariana Abrunheiro (Groucha Vanadzé), Bernardo Eiró, Rita Fernandes; Música - António Victorino d'Almeida; Cenografia - Manoel Ribeiro; Assistente de Cenografia Margarida Sá Machado; Assistentes de Encenação - Guilherme Mendonça, Débora Mateus; Coreografia - Vicente Trindade; Adereços e Máscaras Vítor Sá Machado; Guarda-Roupa - Sandra Pereira; Preparação de Actores em Comedia dell'Arte - Filipe Crawford; Pesquisa Século de Ouro - Rita Lello; Pesquisa Período Isabelino - Guilherme Mendonça; Luz - José 
Carlos Pontes; Som - Fernando Pires; Cartaz - Susana Marques; Mestre Carpinteiro - Mário Dias; Secretariado - Maria Navarro; Produção Executiva - Elsa Lourenço; Colaboradores - Pedro Medeiros, Nuno Raimundo, Paula Coelho, Débora Mateus, Margarida Sá Machado, Oxana Szakharenko.

Nuno S. Rodrigues

\section{Monteiro Lobato, Sítio do Picapau Amarelo - Os Doze Trabalhos de Hércules}

Data da Produção: 2001

Direcção: Márcio Trigo

Exibição: SIC, 2003

Sendo um dos autores mais conhecidos da literatura brasileira, Monteiro Lobato escreveu fundamentalmente textos dedicados a um público infanto-juvenil. O seu Sítio do Picapau Amarelo é um misto de realidade e fantasia, onde as personagens humanas, como a simpática avó, D. Benta, ou a típica cozinheira brasileira, Tia Nastácia, se cruzam com figuras do imaginário e cultura universais, de D. Quixote a Peter Pan, de Branca de Neve a Mandrake, ou com outras propositadamente criadas para este cenário, como a boneca de trapos falante, Emília, ou o sabugo de milho animado e intelectual, conhecido como o Visconde de Sabugosa. Um dos vários livros que dedicou ao Sítio teve como base as histórias de Héracles/Hércules, nomeadamente, o leão de Némea, a hidra de Lerna, a corça dos pés de bronze, o javali de Erimanto, as cavalariças de Áugias, as aves do lago Estínfalo, o touro de Creta, os cavalos de Diomedes, o cinto de Hipólita, os bois de Gérion, o pomo das Hespérides e o cão Cérbero. Neste episódio, os habitantes do sítio transportam-se até ao Mundo Antigo, graças ao seu famoso «pó de pirlimpimpim». Desta vez, os jovens heróis, nomeadamente os pequenos Pedrinho, Narizinho e sua boneca Emília, aqui interpretada por uma criança, acompanham o célebre herói grego nos seus doze trabalhos canónicos.

A adaptação televisiva desta história de Monteiro Lobato coincide com uma nova fase do programa, agora mais moderno que nunca. Exemplo dessa modernidade é esta nova $\mathrm{D}$. Benta que utiliza a internet no sítio. Mas esta não é a primeira viagem à Grécia da família do Sítio do Picapau Amarelo. Já antes se haviam encontrado com vários heróis da mitologia clássica, no episódio $O$ Minotauro. Esse episódio fez parte da série anterior, em que se puderam ver actores como Zilka Salaberry (D. Benta), Reny de Oliveira (Emília), Júlio César (Pedrinho), Rosana Garcia (Narizinho), André Valle (Visconde de Sabugosa), e a participação especial de Gracindo Júnior, 
como Teseu. Nessa ocasião, o episódio dedicado ao monstro de Creta foi apresentado pela RTP. Os novos episódios das adaptações de Monteiro Lobato foram adquiridos pela SIC, que passou a apresentá-los na sua grelha infantil, aos Sábados de manhã.

Nesta nova adaptação, damos uma palava de destaque para as interpretações das actrizes Maria Luiza Mendonça, excepcional como uma contida e serena Atena, e Lília Cabral, uma soberba e neurótica Hera.

Elenco: Actores - Nicette Bruno (D. Benta), César Cardadeiro (Pedrinho), Lara Rodrigues (Narizinho), Cândido Damm (Visconde de Sabugosa), Isabelle Drummond (Emília), Rodrigo Faro (Hércules), Maria Luiza Mendonça (Atena), Lília Cabral (Hera), Leonardo Brício (Belerofonte), Gabriel Bernardo (Ganimedes), Fernando Eiras (Minervino).

Nuno S. Rodrigues

Neil Labute, Socos

Produção: Grupo 4

Versão: João Lourenço e Vera San Payo de Lemos

Encenação: João Lourenço

$1^{a}$ Apresentação: Lisboa, Teatro Aberto

Data: 5. 9. 2001.

Três histórias quotidianas, e aparentemente vulgares, de quatro personagens compõem Socos, uma versão portuguesa da peça Bash: Latterday Plays de Neil Labute. Nascido em 1963, formado em

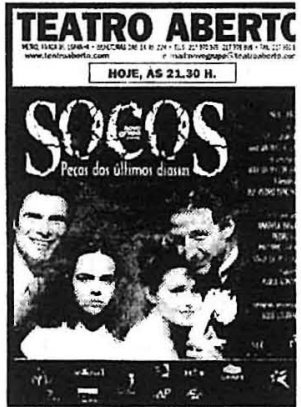
teatro e cinema, este norte-americano foi premiado no Festival de Sundance pela realização do filme Your Friends and Neighbours, e no Festival de Cannes de 2000 pelo argumento do filme Nurse Betty. Em Bash: Latterday Plays explora a ideia de que qualquer ser humano pode ser levado a praticar acções impensáveis e terríveis.

Numa peça que tem como tema basilar a morte, compreende-se a revisitação dos mitos de Ifigénia e Medeia. $\mathrm{Na}$ história que no original se intitula 'Iphigenia in Orem', um homem de negócios desabafa sobre os seus problemas familiares e profissionais, lamentando a morte da filha de oito meses. Mais tarde revelará que a menina foi vítima da sua ambição profissional. A evocação do sacrificio de Ifigénia corrobora a futilidade e horror da sua actuação.

Na segunda peça, 'Medea Redux', uma mulher recorda a sua primeira paixão, aos treze anos, por um professor de Biologia. A sua confissão é, porém, terrível: matou o filho de catorze anos, fruto desse amor. 
Eventualmente, este acto filicida, como na tragédia de Eurípides, é uma manifestação tardia do trauma dessa primeira paixão.

Uma última história, 'A Gaggle of Saints', já não baseada na mitologia grega, mantém os elementos de terror e dramatismo: um par de namorados descreve os acontecimentos banais de um fim-de-semana passado em Nova York. O lado negro é o relato do modo como o jovem, com outros amigos, sovou até à morte um homossexual numa casa-de-banho de Central Park.

O título da encenação portuguesa, Socos, alude ao efeito que os monólogos das personagens provocarão nos espectadores, uma vez que, no começo, as suas histórias são simples e não anunciam um desfecho terrível. Por conseguinte, a essência deste espectáculo assenta no trabalho de representação dos actores e na sua capacidade de, perante o público, passarem de pessoas vulgares a criminosas. Sobre o trabalho de João Lourenço e de Vera San Payo de Lemos escreveu Carlos Porto: "Em quadros que fazem parte da pintura de Edward Hooper, João Lourenço criou essas histórias que não são arrepiantes porque outras, e essas verdadeiras, o são mais. Nem por isso deixamos de apanhar o soco no estômago que o espectáculo impõe. O trabalho dramatúrgico de Vera San Payo de Lemos participa nesse levantamento implacável desta visão do mundo." (Jornal de Letras de 19. 9. 2001).

Elenco: Actores - Anabela Brígida, Pedro Lima, Philippe Leroux, Sofia de Portugal; Dramaturgia - Vera San Payo de Lemos; Filmologia Rui Pedro Tendinha; Figurinos - Maria Gonzaga; Cenário e Música - João Lourenço; Luzes - João Lourenço, Malim Teixeira.

Mendelssohn, Um Sonho de uma Noite de Verão Produção: Companhia Nacional de Bailado Coreografia: Gay Veredon $1^{a}$ Apresentação: Lisboa, Teatro Nacional de São Carlos Data: Outubro de 1988.

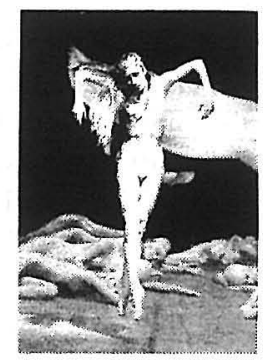


Mendelssohn, Um Sonho de uma Noite de Verão

Produção: Companhia Nacional de Bailado

Coreografia: Armando Jorge

$1^{a}$ Apresentação: Évora, Teatro Garcia de Resende

Data: 14.7.1995.

Ana Paula Quintela Sottomayor

Mendelssohn, Um Sonho de uma Noite de Verão

Produção: Companhia Nacional de Bailado

Coreografia: Armando Jorge (versão adaptada aos Jardins do Palácio Nacional de Queluz)

Iniciativa: Noites de Bailado

$1^{a}$ Apresentação: Sintra, Jardins do Palácio Nacional de Queluz

Data: 21-23 e 28-30. 7. 1995.

Elenco: Bailarinos - Mariana Paz ou Filipa Rola (Hipólita), Sávio de Luna ou Brent Williamson (Teseu), Ana Lacerda ou Mariana Paz (Hérmia), Alistair Main-Wintle ou Mário Franco (Demétrio), Catarina Lourenço (Helena), Alexandre Fernandes ou Sávio de Luna (Lisandro), Rui Lopes Graça ou Jurandi Silva (Puck), Didier Chazeau ou Alistair MainWintle (Oberon), Cristina Maciel ou Adeline Charpentier (Titânia), Elizabeth Lopez ou Filomena Pinto (Flor de Amor), Rafael Monteiro (tecelão), Brent Williamson ou Armando Maciel (carpinteiro), Pedro Carneiro (sapateiro), João Carlos Petrucci (alfaiate), Álvaro Santos (marceneiro), Paulo Fonseca (latoeiro); Annabel Barnes, Carla Pereira, Cristina de Jesus, Filomena Pinto ou Elizabeth Lopez, Guiomar Machado, Isabel Frederico, Margarida Pimenta, Maria João Pinto, Marina Figueiredo e Susana Matos (Fadas); Bernardo Gama, David Fielding, João Taquelim, José Carlos Oliveira, Marco Arantes e Rui Alexandre (Elfos); Elsa Madeira, Helena Marques, Isabel Galriça, Isadora Ribeiro, Paulina Santos, Rute Lopes, Sílvia Santos, Teresa Aurora, Bernardo Gama, David Fielding, João Carlos Petrucci, João Taquelim, José Carlos Oliveira, Luís Albergaria, Marco Arantes, Rui Alexandre (comitiva de Teseu e de Hipólita); Cenografia e Figurinos Nuno Côrte-Real; Desenho de Luzes - Pedro Martins; Assistente do Coreógrafo - Maria José Palmeirim; Ensaiadoras - Kimberley Ribeiro e Isabel Fernandes; Assistente Musical - Ana Paula Ferreira; Direç̧ão dos Bailarinos-Actores - Pedro Pinheiro. 


\section{William Shakespeare, Sonho de uma noite de Verão \\ Produção: TEUC/Teatro e Educação da Escola Superior de Educação de Coimbra \\ Encenação: António Mercado \\ $1^{\text {a }}$ Apresentação: Condeixa, Teatro dos Bombeiros Voluntários \\ Data: 29-30 . 5. 2001 \\ Outras: Coimbra (Teatro de S. Teotónio), 13-17. 6. 2001; Évora (Teatro Garcia de Resende), 22-23 . 6. 2001; Aveiro (Estaleiro Teatral), 28-29. 6. 2001.}

Esta foi considerada a maior produção do TEUC dos últimos anos, sendo simultaneamente a primeira vez, em trinta anos, que um grupo de teatro de Coimbra levou à cena um texto de Shakespeare (nos anos 70 levara Hamlet), e a estreia deste texto naquela cidade. A forma como o público aderiu ao espectáculo revelou o êxito da produção, visto que a bilheteira esgotou consecutivamente todos os dias previstos no calendário da produção, havendo, inclusivamente, que apresentar um espectáculo extra.

Esta produção, que marcou uma polémica com a direcção do Teatro Gil Vicente, teve a particularidade do trabalho conjunto com a ESEC, tendo participado seis alunos desta instituição no projecto. Paralelamente, houve um trabalho de sensibilização dos alunos das escolas dos $2^{\circ}$ e $3^{\circ}$ ciclos para que assistissem àquela que é a mais encenada das peças de Shakespeare. Uma nota para a introdução de uma personagem, Nédar, mãe de Helena, representada pela actriz Constança Providência.

Elenco: Actores- Nelson Rodrigues (Teseu, Duque de Atenas), Sandra Silvestre (Hipólita, Rainha das Amazonas), João Castro Gomes (Egeu, pai de Hérmia), Carla Nunes (Hérmia, filha de Egeu), Luísa Teles (Hérmia, filha de Egeu), Rui Guerreiro (Demétrio, pretendente de Hérmia), Tiago Sobral Gonçalves (Lisandro, namorado de Hérmia), Neusa Dias (Helena, apaixonada de Demétrio), Constança Providência (Nédar, mãe de Helena), Filipe da Costa (Pedro Pinho, carpinteiro), Zé Tó Mariz (Zé Bobina, tecelão), Ricardo Brito (António Alfacinha, hortelão), Tiago Pires (Mangalarga, alfaiate), Alberto Ferreira (João Latão, funileiro), Luís Rodrigues (Chico Serra, marceneiro), Filipe Carvalho (Puck, duende), Diogo Jorge Pinto (Oberon, rei das fadas e dos elfos), Tânia Pereira (Titânia, rainha das fadas e dos elfos), Patrícia Portugal (Flor de Ervilha), Sandra Soares (Teia de Aranha), Inês Mourão (Falena), Mónica Tavares (Grão de Mostarda); Coordenação- António Mercado; Cenografia e Figurinos- José Carlos Faria; Adereços- Cláudio Louzada; Desenho de Luz- António Mercado; Sonoplastia- António Mercado, João Gomes, Nuno Trocado, Rui Capitão; Direcção de Cena- Nelson Rodrigues; Produção CenográficaIsabel Craveiro; Figurinos/Adereços- Carla Nunes; Direç̧ão TécnicaNuno Trocado; Técnicos de Iluminação- João Gomes, Nuno Trocado, Rui 
Capitão; Operador de Luz- Nuno Trocado; Técnicos de Som- João Gomes, Nuno Trocado, Rui Capitão; Operador de Som- Rui Capitão; ContraRegra- João Gomes; Guarda-Roupa- Carla Nunes, Tânia Pereira; Cabeleireiros- Ilídio Design; Bilheteira- Carla Fino; Administração da Sala- Ana Maria Castro; Coordenação de Imagem e Relações PúblicasFilipe da Costa; Produção Executiva- Neusa Dias.

Nuno S. Rodrigues

\section{William Shakespeare, Sonho de uma noite de Verão}

Produção: Paulo Lages/Serviço Educativo do Palácio Nacional da Ajuda/Instituto Português do Património Arquitectónico

Encenação: Paulo Lages

$1^{a}$ Apresentação: Palácio Nacional da Ajuda

Data: 31. 5-9. 6. 2001.

O tema de Teseu e Hipólita associado à mitologia céltica retornou aos palcos portugueses, desta vez numa iniciativa apoiada pelo Serviço Educativo do Palácio Nacional da Ajuda e do Instituto Português do Património Arquitectónico, aí instalado. Trata-se de um espectáculo que teve como objectivo principal o público infantil, animando o espaço régio. Desta vez, a trama shakespeareana é contada por um narrador, o rei D. Luís, que era, como se sabe, um apaixonado e tradutor do bardo inglês. Nesta tarefa, o rei é auxiliado pelo seu mordomo, com quem vai reconstituindo a história. Esta produção teve como participação especial a fanfarra da Polícia de Segurança Pública de Lisboa, cujo efeito musical se revelou de grande importância.

Elenco: Actores- Paulo Lages, Pedro Leitão, Nuno Pinto.

Nuno S. Rodrigues

\section{William Shakespeare, Sonho de uma noite de Verão \\ Produção: Companhia de Bailado da Ópera Alemã do Reno \\ Encenação/Coreografia: Birgit Cullberg \\ $1^{\text {a }}$ Apresentação: Sintra, Jardins de Seteais \\ Data: 31.5-2. 9. 2001.}

No âmbito do Festival de Sintra, a Companhia de Bailado da Ópera Alemã do Reno apresentou, nos belos jardins do palácio de Seteais, em Sintra, a famosa comédia de Shakespeare. Obedecendo à directriz que tem 
norteado a política coreográfica daquela companhia, esta encenação regeu-se pela fusão do bailado clássico com a dança moderna. Sonho de uma noite de Verão juntou-se assim à lista, já grande, de espectáculos a que o público de Sintra tem vindo a assistir nos últimos anos.

Nuno S. Rodrigues

\section{William Shakespeare, Sonho de uma noite de Verão}

Produção: Escola Secundária Vergílio Ferreira

Encenação/coordenação: Alfredo Nunes

$1^{a}$ Apresentação: Auditório do Seminário da Luz

Data: 20-21. 3. 2002.

Shakespeare.

Trata-se de mais uma produção escolar da célebre peça de

Nuno S. Rodrigues

\section{William Shakespeare, Sonho de uma noite de Verão}

Produção: Brincaraoteatro.com-E.S. José Régio (Vila do Conde)

$1^{a}$ Apresentação: Auditório Municipal da Póvoa do Varzim

Data: 11. 4. 2002.

Numa iniciativa da II Mostra de Teatro Escolar, esta companhia sediada na escola José Régio, de Vila do Conde, encenou e apresentou Sonho de uma noite de Verão.

Nuno S. Rodrigues

\section{William Shakespeare, Sonho de uma noite de Verão}

Produção: Teatro Tapa Furos

Encenação: Rui Mário

$1^{\text {a }}$ Apresentação: Sintra, Quinta da Regaleira

Data: Julho-Agosto de 2002.

Esta produção retoma o já instalado hábito de encenar o texto de Shakespeare num local ao ar livre, de preferência arborizado. Desta vez, o cenário escolhido foi o espaço privilegiado da Quinta da Regaleira, em Sintra, onde os artesãos de Atenas encenam a peça de teatro com que vão 
presentear Teseu, Duque de Atenas, e as fadas e os elfos se misturam com as personagens gregas, criadas pela pena do bardo inglês. Tal como em outras produções, o público assiste ao espectáculo seguindo os actores que o lideram num passeio nocturno pelas misteriosas sendas da Regaleira e onde o perfil da serra de Sintra completa o cenário. Esta é uma produção típica de uma noite de Verão.

Elenco: Actores- Bárbara Santos, Carla Guerreiro; Música Original- Pedro Hilário; Desenho de Luz- José Miguel Antunes.

Nuno S. Rodrigues

\author{
William Shakespeare/Mendelssohn, Sonho de uma noite de Verão \\ Produção: Orquestra do Norte \\ Direcção de Orquestra: José Ferreira Lobo \\ $1^{a}$ Apresentação: Guimarães, Paço dos Duques \\ Data: 4. 7. 2002 \\ Outras: Igreja de Fão (Esposende).
}

Trata-se de uma apresentação da partitura de Mendelssohn, composta com base na comédia de Shakespeare, cuja acção se passa em Atenas, sob a liderança de Teseu e Hipólita. Esta obra, contudo, limita-se à partitura musical.

Nuno S. Rodrigues

\title{
William Shakespeare, Sonho de uma noite de Verão
}

Produção: Filandorra-Teatro do Nordeste

Data: 2002.

Do programa de 2002, desta companhia subsidiada pelo Ministério da Cultura e pelo IPAE, fez parte a mais célebre das comédias de Shakespeare.

Nuno S. Rodrigues 


\section{William Shakespeare, Sonho de uma noite de Verão \\ Produção: Fatias de Cá \\ Encenação: Carlos Carvalheiro \\ $1^{\text {a }}$ Apresentação: Tomar, Mata Nacional dos Sete Montes \\ Data: Junho a 11. 9. 2002.}

Ao mesmo tempo que a produção apresentada na Quinta da Regaleira, em Sintra, decorreu em Tomar, em igual cenário bucólico e ao ar livre, na Mata dos Sete Montes, esta produção das Fatias de Cá, já veteranas nesta encenação, de Um sonho de uma noite de Verão. A particularidade desta produção reside no facto de o público chegar à Mata ao fim da tarde, deambular atrás das personagens e, no final, ser convidado a jantar com os actores da companhia. Esta encenação teve como fundo musical a partitura de Mendelssohn com o mesmo nome, o que é recorrente nas encenações desta comédia de Shakespeare.

Elenco: Actores- Ana de Carvalho, Ana Paula Eusébio, Bruno Guerra, Carlos Carvalheiro, Catarina Ferreira; Música- Mendelssohn.

Nuno S. Rodrigues

Hélia Correia, Sonho de uma Noite de Verão (adaptação do texto de Shakespeare)

Encenação: João Ricardo

$1^{\mathrm{a}}$ Apresentação: Teatro Nacional D. Maria II

Data: 22. 11-20. 12. 2003.

Esta é uma versão de Shakespeare que Hélia Correia preparou especialmente para um público infantil.

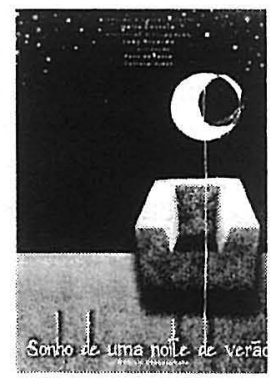

Elenco: Actores - Ana Rocha, Ana Piu, André Amálio, Edmundo Rosa, Filipe Valentim, Francisco Brás, João Gualdino, João Pedreiro, Lavínia Moreira, Lília Matos, Maria Gil, Paula Só, Pedro Gil, Rita Martins, Sara Gonçalves; Direcção de Actores - Teresa Lima; Cenografia - Rui Francisco; Figurinos - Maria Gonzaga; Desenho de Luz - Bruno Gaspar.

M. F. S. S. 
F. Mendelssohn, P. Glass, S. Reich, Sonho de uma Noite de Verão

Produção: Companhia Nacional de Bailado

Director Artístico: Mehmet Balkan

Coreografia: Heinz Spoerli

Execução Musical: Orquestra Filarmonia das Beiras

Direcção Musical: James Tuggle

$1^{\text {a }}$ Apresentação: Lisboa, Teatro Camões (Parque das Nações)

Data: 4, 5, 6, 8, 18, 19, 20. 6. 2004

Outras: Santa Maria da Feira (Europarque), 2, 3. 6. 2004.

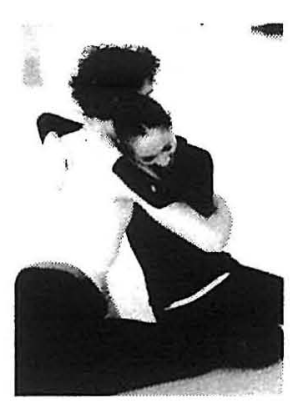

M. F. S. S.

\section{Tiresia}

Argumento e Realização: Bertrand Bonello Iniciativa: Festa do Cinema Francês 2003 Alliance Française de Coimbra

$1^{\text {a }}$ Apresentação: Coimbra, Cinema Millenium Avenida

Data: 21. 10. 2003

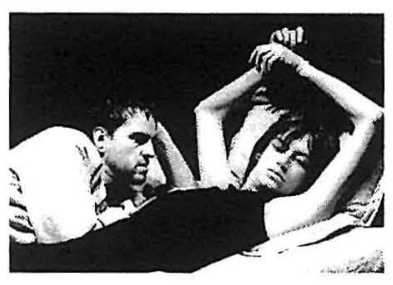

Este filme, apresentado e seleccionado no Festival de Cannes de 2003 - Competição oficial, é uma adaptação livre do mito grego de Tirésias. Conta a história de um transexual brasileiro raptado no Bois de Bologne por um homem, que depois o sequestra numa cave. A partir daí o raptor, fascinado pela sua vítima, passa a mirá-la como se de objecto raro se tratasse, enquanto o sequestrado, privado de tratamento hormonal, vai perdendo a sua feminilidade. Em desespero, o seu carrasco apaixonado cega-o e abandona-o. Encontrado e salvo por uma jovem, Tiresia convalescente revela dons proféticos que atraem sobre a sua pessoa muitas atenções, mas também a desconfiança das autoridades religiosas locais.

Elenco: Actores - Laurent Lucas, Clara Choveaux, Thiago Theles, Célia Catalifo, Lou Castel, Alex Descas, Olivier Torres; Fotografia - Josée Deshaies; Produção - Carole Scotta, Simon Arnal-Szlovak, Luc Déry; Música - Laurie Markovitch, Albin de la Simone, Beethoven. 
Tróia

Realização Cinematográfica: Wolfgang Petersen Iniciativa: Warner Bros., Village Roadshow Pictures, Radiant Productions, Plan B Films, Estados Unidos (2004)

Estreia (em Portugal): 13. 5. 2004.

Estreou entre nós, no passado dia 13 de maio de 2004, o filme Troy de Wolfgang Petersen, realizador conhecido pelas suas produções para o grande público. $\mathrm{O}$ filme era já há algum tempo

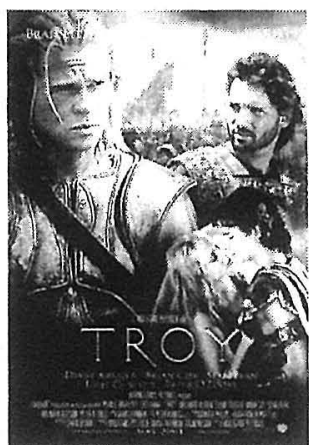
esperado pelos críticos e pelos estudiosos dos temas clássicos (e de Homero em particular).

Passar para o grande ecrã a acção da Iliada de Homero seria, por si só, uma tarefa de gigantescas dimensões. Agora se atentarmos que, de facto, a acção do filme transcende os limites deste poema, indo recuperar elementos da Odisseia, das Troianas de Séneca e das tragédias áticas dedicadas ao tema, a dificuldade aumenta. Mas com ela aumenta, segundo nos parece, o interesse. De resto, não faltou já quem apontasse como crítica desfavorável o facto de a fita conter elementos exteriores à Ilíada. Comentários como estes carecem contudo de cautela. Basta pensarmos que a produção se chama Tróia e não é homónima do poema. Daí que se procure dar os antecedentes da guerra de Tróia, onde são bem visíveis as verdadeiras intenções de Agamémnon - dominar todo o mar Egeu, com a conquista da cidade cujas muralhas têm fama de ser indestrutíveis. $\mathrm{O}$ argumentista e o realizador têm, neste sentido, uma liberdade plena para proceder às adaptações e mesmo às alterações que o espectador mais atento pôde constatar.

O fio condutor da película é, sem dúvida, a Fama, a Imortalidade pelos feitos heróicos do guerreiro, algo que não era estranho a Homero, antes pelo contrário. Curiosa a adaptação do encontro entre Aquiles e a mãe - a suposta deusa Tétis - onde esta lhe revela precisamente, à semelhança do poema, que se for para Tróia não regressará com vida, mas que, em contrapartida, será imortal o seu nome. Ora, o nome de Aquiles transpôs de facto as barreiras do tempo, mas custa-nos a conceber que tal tivesse acontecido se o herói homérico fosse o do cineasta. O Aquiles de Wolfgang Petersen (Brad Pitt) não tem, de facto, a nobreza de carácter que lhe imprimiu o cego poeta de Quios. Ele é, de resto, a coluna vertebral de um apurado processo de barbarização dos Gregos, em contraste com a integridade do lado troiano. Assim, é na casta de Tróia que, na visão cinematográfica, encontramos os verdadeiros heróis. Excluindo Páris (Orlando Bloom) e a sua cobardia (não muito desconcertante para o leitor homérico), Heitor (Eric Bana) e Príamo (Peter O'Toole) são de facto a súmula dos valores guerreiros e humanos. O primeiro, pela terna cena familiar com Andrómaca (Saffron Burrows) e o pequeno Astíanax, mas também pela honra e integridade que 
imprime a todos os seus combates. Príamo, o perfeito governante e o comovido pai, que ama a seus filhos como a cada grão de areia do seu reino. Ele que acolhe Helena (Diane Kruger) só porque ama o seu filho mais novo, pormenor tipicamente Holliwoodesco que, contudo, não deixa de auxiliar na heroicização e sublimação desta figura. Eles são a dupla de aristoi do filme, em contraste com a arrogância tirânica de Agamémnon (Brian Cox) e a raiva orgulhosa de Menelau (Brendan Gleeson), da facção grega.

Não está também ausente do filme o tópos da cólera funesta de Aquiles, que abre o poema e o acompanha como fio condutor. Há talvez um exagero no tratamento dado à insurreição do Pelida para com Agamémnon, mas é após a morte de Pátroclo que, tal como na narrativa, vemos actuar um Aquiles verdadeiramente enfurecido, que mata e arrasta o corpo de Heitor à volta das muralhas. Mas novamente nos parece que a exigência do papel foi demasiada para o actor escolhido, o que resultou numa cólera mais infantil, menos nobre.

Há todo um conjunto de cenas claramente ao serviço das intenções comerciais do filme, como sejam o romance entre Aquiles e Briseida (Rose Byrne), a paixão avassaladora de Páris por Helena, como se apenas ela fosse responsável por toda a acção. Isto para já não falar da desconcertante morte de Agamémnon na guerra, o que retiraria toda a lógica do seu assassinato às mãos de Clitemnestra. Um esforço de adaptação que elimina alguma carga heróica ao filme, como se dele dependesse a atracção do público. Pena é verificar, de facto, que talvez dependa disso mesmo, que talvez não tenha já a moral heróica grande recepção entre os homens que assistem a uma longa metragem milionária.

Mas há também outras cenas muito bem recuperadas. Basta pensarmos nos cenários, nas muralhas de Tróia, nas técnicas de combate, na caracterização do herói armado. Há um momento de particular interesse, que atesta a pesquisa que esteve, decerto, por trás da redacção do argumento. Falamos do armar do guerreiro, cena típica da aristeia de um herói. Na fita que estamos a comentar, vemos Heitor e Aquiles a armarem-se em simultâneo, preparando-se para aquele que será, para o primeiro, o derradeiro combate. Salta à vista o brilho do bronze, tantas vezes alvo das descrições e dos símiles homéricos. Mas também os funerais e a admiração dada ao cadáver do herói caído em combate, sobre cujos olhos se colocam as moedas para o barqueiro infernal. As tréguas de doze dias para os funerais de Heitor, entre outros aspectos, são respeitadas. E o filme termina com Tróia em chamas e com a entrega da espada da cidade a Eneias, que por ali aparece por acaso, com o pai Anquises às costas. Que proveitoso para os interesses de Virgílio, diríamos, não fosse esta cena das mais gratuitas e dispensáveis de toda a obra cinematográfica!

Entre a épica e as exigências do blockbuster, entre a sensação heróica dos quadros de combate e alguns romances exacerbados, cativantes contudo, é assim Tróia de Wolfgang Petersen. Um filme longo, atractivo e 
movimentado, bem ao estilo das produções épicas de Holliwood (cujo último ciclo foi iniciado por $O$ Gladiador, em 1999) com falhas perdoáveis se atendermos aos seus propósitos.

A mais bela de todas as mulheres, a mais lendária de todas as guerras, o mais bravo guerreiro de todos os tempos, um dos mais latos e poderosos impérios de todo o sempre. A Fama, a necessidade de perdurar na memória dos mortais depois de feito o corpo em cinzas, depois mesmo que estas se evolam no ar para não mais existir. A Memória dos homens é fraca, volátil. Os varões assinalados, nos livros ou num ecrã de cinema, incentivam à acção e ao sonho. Tróia, queiramos ou não, contribuiu para esse renascer das cinzas de um mito cujas labaredas não podem extinguir-se, jamais.

Elenco: Actores - Brad Pitt (Aquiles), Eric Bana (Heitor), Orlando Bloom (Páris), Diane Kruger (Helena), Brian Cox (Agamémnon), Brendan Gleeson (Menelau), Peter O'Toole (Príamo), Garrett Hedlund (Pátroclo), Sean Bean (Ulisses), Saffron Burrows (Andrómaca), Rose Byrne (Briseida); Produção - Wolfgang Petersen, Diana Rathbun, Colin Wilson; Co-produção - Winston Azzopardi; Guião - David Benioff; Fotografía - Roger Pratt; Música - James Horner; Direçãa Artística - Julian Ashby, Jon Billington, Andy Nicholson, Adam O'Neill; Cenografia - Anna Pinnock, Peter Youngblood Hills; Efeitos Visuais - Chas Jarrett, Steve Parsons, Jon Thum; Efeitos Especiais - Joss Williams.

Carlos A. Martins de Jesus 
(Página deixada propositadamente em branco) 


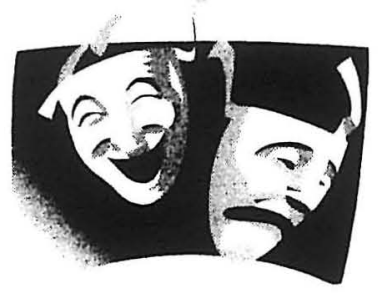

PlaUto 
(Página deixada propositadamente em branco) 


\title{
ANFITRIÃO
}

\author{
Plauto, $O$ Anfitrião \\ Produção: Thíasos \\ Encenação e Adaptação: Victor \\ Torres \\ Tradução: C. A. Louro Fonseca \\ 1. ${ }^{a}$ Apresentação: Coimbra, Museu \\ Machado de Castro \\ Data: 11. 4. 2002
}

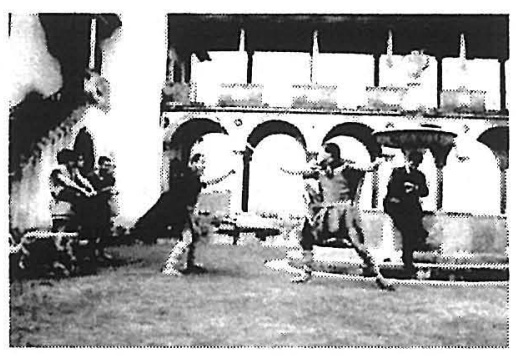

Outras: Viseu (Anfiteatro do IPJ), 12. 4. 2002; Conimbriga, 15. 4. 2002; Centro Cultural da Mêda, 20. 4. 2002; Lisboa (Pátio Grego da Faculdade de Letras), 15. 5. 2002; Coimbra (Museu Nacional Machado de Castro), 25. 6. 2002; Alcalá de Henares (Casa de Hippolitus), 3. 4. 2003; Conimbriga, 6. 5. 2003; Conimbriga, 15. 5. 2003; Museu Arqueológico de S. Miguel de Odrinhas, 16. 5. 2003; Figueira da Foz (Centro de Artes e Espectáculos) 18. 5. 2003; Braga (Museu D. Diogo de Sousa), 6. 6. 2003; Braga (Mosteiro de S. Martinho de Tibães), 27. 4. 2004; Coimbra (Antigo Convento de Santana, actual Quartel General), 28. 4. 2004; Figueira da Foz (Centro de Artes e Espectáculos), 17. 6. 2004.

Foi a terceira vez que o Thíasos encenou Plauto; já antes Carlos Alberto Louro Fonseca tinha encenado uma parte de $O$ soldado fanfarrão e Paulo Sérgio Ferreira $O$ Epídico. A encenação coube a Victor Torres, que tem vasta experiência como actor teatral, e a expectativa era grande para ver o que poderia trazer de novo alguém do meio teatral a um grupo de teatro universitário, maioritariamente constituído por professores e alunos do Instituto de Estudos Clássicos.

$\mathrm{O}$ resultado não defraudou as expectativas, pois Victor Torres encontrou algumas soluções dramáticas brilhantes, embora bem distantes da arqueologia teatral romana: pensamos nas portas em pano que, quando alguém simulava bater, abanavam todas, enquanto outra pessoa, fora do palco, batia numas chapas que faziam grande estrondo. A cena de amor em palco entre Júpiter e Alcmena, em que Brómia coloca um leve pano sobre o casal, é outro achado. As duas pessoas que se escondem atrás de um pano e o fazem tremer também sugerem bastante bem as sombras nocturnas e justificam, de forma bastante cómica, os temores de Sósia. Boa opção foi ainda a distribuição da longa intervenção final de Brómia por três actrizes com trejeitos e vozes completamente diferentes. Já que era de prodígios que esse relato falava....

Quanto aos desempenhos, importa destacar o de Delfim Leão, que foi um Júpiter enérgico e coerente. Nuno Gertrudes foi um Sósia que, com tamanha confusão, quase ia ficando louco. Levou muita paulada de Mercúrio 
e andou com Anfitrião às costas, quando, ao sair do palco, atravessava um rio. Esta cena não tinha, de resto, grande fundamento dramático e, quando Nuno Gertrudes demorava a desapertar as sandálias, verificava-se um tempo morto. Muito sóbria e convincente foi Sílvia Costa no papel de Alcmena: até amuou e fez beicinho.

Em suma, o balanço é bem positivo, sobretudo pela qualidade de muitas das soluções encontradas, que permitiram conseguir efeitos muito bonitos, sem sobrecarregar o palco com cenários pesados.

Elenco: Actores - Paulo Sérgio Margarido (Relator Inicial), José Luís Brandão (Anfitrião), Nuno Gertrudes (Sósia), Delfim Leão (Júpiter), Bruno Amaral (Mercúrio), Sílvia Costa / Ana Catarina Rodrigues (Alcmena), Carla Braz, Amélia Álvaro de Campos / Lia Nunes, Susana Bastos / Verónica Fachada (Brómias), Patrícia Martinho / Sónia Simões, Sónia Freitas / Isabel dos Santos (Figurantes); Direcção de Actores - Victor Torres; Consultor José Luís Brandão; Luminotecnia - Carlos Santos; Sonoplastia - Isidro Alves / Carlos Jesus; Selecção Musical - Victor Torres; Figurinos - Ana Balula, José Luís Brandão; Execução do Guarda-Roupa - Inês Santos; Adereços - Ana Balula, Carlos Santos, Victor Torres.

Paulo Sérgio Ferreira

\section{COMÉDIA DA MARMITA}

Plauto, A Comédia da Marmita

Produção: Grupo Balbo do IES Santo Domingo, de Puerto de Santa Maria (Cádis)

Encenação: Emilio Flor Jiménez

Iniciativa: III Festival Escolar de Teatro de Tema Clássico

$1^{\text {a }}$ Apresentação: Conímbriga

Data: 27 . 4 . 2001

Outras: Conímbriga, 10 .6 . 2001; Braga (Termas Romanas), 8. 7 . 2001;

Citânia de Sanfins, Paços de Ferreira, 9 . 7 . 2002; Coimbra, 28 . 4 . 2003; Braga (Mosteiro de Tibães), 30 . 4 . 2003.

Na linha dos hábitos de trabalho deste grupo, a encenação da peça tem assumidamente um carácter didáctico na medida em que, nas palavras de apresentação, se declara a intenção de colocar em palco as técnicas da comédia latina, especialmente de Plauto: representar os tipos plautinos, lançar mão dos vários tipos de cómico, especialmente o burlesco que tanto agradava à ralé romana, introduzir o canto e a quebra da ilusão cénica. 
As apresentações em Portugal têm sido promovidas pelos Festivais de Teatro de Tema Clássico, de quem o Grupo Balbo já se tornou um convidado habitual.

Elenco: Actores - Marcos Collado Martín (Megadoro), Nerea Miranda Ramirez (Eunómia), Fátima Jiménez Enrique (Licónides, Ântrax), Eva Rodríguez Cruz (Congrião), Jesús María Gutiérrez Torres (Estrobilo), Javier Ortega (Euclião), Patrícia López (Estáfila), Luisa Pinto Tey (Velha Rica), María Isabel Crespo García (Fedra), Jorge Romo Serrano (deus Lar da Família); Bailarinas - Esther Pumar Reys, Lisi Mena Linder, Marga Domínguez Sánchez, María Isabel Crespo García; Mimos - Jorge Romo Serrano, Jesús María Gutiérrez Torres, Adrian Varo García; Flautistas Jorge Romo Serrano, Adrian Varo García; Luminotéenica - Joaco Arjona; Sonoplastia - Antonio Pecho; Guarda-Roupa e Adereços - trabalho colectivo do grupo.

José Luís Brandão

\section{Plauto, Aulularia ou A Comédia da Panela}

Encenação: José Teles

Iniciativa: Mostra de Teatro Amador

$1^{a}$ Apresentação: Amadora, Teatro D. João V (Largo da Igreja)

Data: Outubro de 2003.

M. F.S. S

Molière, $\boldsymbol{O}$ Avarento

Produção: Grupo de Teatro de Calvão

Encenação: Orlando Matias

1. ${ }^{a}$ Apresentação: Calvão

Data: 1984

Outras: Murtosa.

Elenco: Actores - Manuel Pinho (Harpagão), Júlio Dinis (Cleanto), Angelina Dinis (Elisa), Manuela Pinho (Mariana), Francisco Dinis (Anselmo), Rosa Loira (Eufrosina), Orlando Matias (Mestre Simão), David Malta (Tiago), Leonel Rocha (Comissário), Armindo Jesus (Ajudante); Cenografia - Paulo Frade. 


\section{MENECMOS}

Plauto, Os dois Menecmos

Produção: Grupo Sardiña (IES, E1 Piña, Galiza)

Iniciativa: III Festival de Teatro de Tema Clássico

$1^{\text {a }}$ Apresentação: Conimbriga

Data: 3. 5. 2002.

Paulo Sérgio Ferreira

Plauto, Os Dois Menecmos

Produção: Grupo de Teatro 'O Noémio'

$1^{\mathrm{a}}$ Apresentação: Guarda, Auditório Municipal

Data: 29. 2. 2004.

Elenco: Actores - Marcos Terra, Bruno Pina.

M. F. S. S.

Plauto, Os dois Menecmos

Produção: Nova Comédia Bracarense - Companhia de Teatro Amador de Braga

Encenação: Carlos Barbosa, Vasco Oliveira

Tradução: Carlos Alberto Louro Fonseca

1. ${ }^{\mathrm{a}}$ Apresentação: ?

Data: ?

Outras: Leça (Salão Paroquial), 15. 11. 2003; Gafanha da Nazaré (Centro Cultural), 15. 5. 2004; Lamaçães (Salão da Junta de Freguesia), 22. 5. 2004.

A Nova Comédia Bracarense, levou à cena, no âmbito do Festival de Teatro do Concelho de ílhavo, que decorreu entre 3 e 30 de maio de 2004, Os dois Menecmos de Plauto, em tradução de Carlos Alberto Louro da Fonseca. Como o Menecmo representado na capa da edição do INIC, também os Menecmos desta peça usavam uma coroa de louro e vestes longas. Ao contrário da imagem da capa, contudo, as roupas dos Menecmos bracarenses davam-lhes um ar pesado.

O palco, despido de quaisquer adereços, tinha uma espécie de pórtico de cada lado, a marcar as entradas das casas de Menecmo I, à direita do espectador, e de Erócio, à esquerda. As colunas foram frequentemente utilizadas para as personagens se esconderem e escutarem o que outras diziam. 
Quanto às personagens, foram bem brejeiras, à boa maneira plautina, e sobressaiu o actor que desempenhou o papel de Menecmo II: mostrou-se suficientemente esperto para tirar partido dos quiproquós criados pelos sucessivos aparecimentos dos simillimi. Além disso, conseguiu ser um louco convincente, quando disso teve necessidade. O Escova era demasiado magro para parasita. Messenião conseguiu ser bem ágil, esperto e mesmo atrevido, mas, por vezes, pouco perceptível. Erócio desfez-se em sedução, que, depois, deu lugar ao desprezo. A Mulher do Menecmo I teve alguma dificuldade em se fazer ouvir.

O espectáculo da companhia bracarense mostra bem a vitalidade do teatro clássico e a sua capacidade de continuar a agradar a actores, encenadores e público em geral.

Paulo Sérgio Ferreira

\section{MOSTELLARIA}

\section{Plauto, Comédia do Fantasma}

Produção: Grupo Balbo, do IES Santo Domingo, de Puerto de Santa Maria (Cádis)

Encenação: Emilio Flor Jiménez

1. ${ }^{\text {A }}$ Apresentação (em Portugal): Coimbra, Praça 8 de Maio

Data: 5.7 .2002

Outras: Castelo de Montemor-o-Velho, 29. 4. 2003; Figueira da Foz (Centro de Artes e Espectáculos),11.7. 2003; Coimbra (Praça 8 de Maio), 12. 7. 2003.

Depois de ter criado, entre outros, os grupos Histrión, Antinoe, Baco, Emilio Flor Jiménez fundou o Balbo, inspirado no nome da ilustre família que exerceu uma importante actividade reformadora em Gades. Desde 1974/1975, ano em que começou a leccionar latim, Emilio Flor Jiménez tem dado grande importância ao teatro greco-latino como instrumento pedagógico-didáctico privilegiado no ensino do latim e da cultura clássica, por um lado, e do próprio teatro, por outro. O professorencenador espera, assim, despertar ou fomentar, nos jovens que dirige e no público que assiste às suas peças, o gosto pela leitura e pelo teatro.

Mais importante ainda que a função pedagógico-didáctica é a formativa, pois o teatro contribui para estreitar os laços de amizade entre os jovens, desenvolver a sua capacidade de trabalho em equipa e aumentar a sua auto-estima. Ao apresentarem o seu trabalho a milhares de pessoas de vários países, jovens com idades compreendidas entre os 17 e os 25 anos têm oportunidade de ver o seu esforço reconhecido.

Sugestivo do espírito que preside a cada encenação de comédia e a cada actuação é o convite que Emilio Flor Jiménez dirige ao público, no 
início de cada espectáculo: "Sitúense entre las sillas de este hermoso e histórico edificio, y déjense llevar por un grupo de jóvenes: ayer, severos, disciplinados y serios; hoy, pícaros, desvergonzados y vulgares, para que modifiquemos nuestro silencio y nuestra compostura en risas y carcajadas participando en el espíritu de la fiesta del teatro.»

No folheto distribuído antes do espectáculo começar ainda se diz que, na encenação da Mostellaria, houve a preocupação de realçar os aspectos que a palliata tinha herdado de formas itálicas primitivas, como a atelana, o mimo, a satura e os versos fesceninos.

O Balbo propõe, deste modo, ao público, uma satura composta por comédia musical, ópera cómica, canto, opereta, música, interlúdios musicais, baile, dança, gracejos, gesticulação exagerada e ritmo frenético. A liberdade cómica ainda permitiu ao grupo dispor de actores-mimos que, embora ausentes do texto da peça, reflectem a grande adesão dos alunos a este tipo de projecto e, de algum modo, enriquecem o próprio cenário.

Em alguns momentos, houve necessidade de adaptar a própria tradução, de modo a transmitir, de forma mais eficaz e clara, a riqueza e o lirismo do original. O canto, além de evitar a monotonia, realça os momentos mais importantes.

O Balbo pretende que os alunos que assistam à peça reconheçam «la tipificación elemental de los personajes, el movimiento (comoedia motoria), la pérdida de la ilusión escénica, los equívocos lingüísticos y de situaciones, el juego de palabras, el habla popular, el italum acetum, la grosería, la tramoya, vestimenta exagerada, el sabor rural, la crítica social velada, la ausencia de contenido político, la falta de estudio psicológico de los personajes, la contaminatio, la pantomima, la vivacidad en el diálogo y en las acciones, los diverba, los cantica.»

O grupo não deixa ainda de advertir o público de que a improvisação, fruto do contacto com os espectadores, estará pontualmente presente no espectáculo. Alguma reacção do público estava, de resto, pressuposta nas palhaçadas, nos pedidos de silêncio ou de colaboração dirigidos aos espectadores romanos, nas reiteradas advertências, na captatio beneuolentiae dos prólogos, nas alusões à actualidade, nas repetições e nas zombarias do escravo. Nessa interacção frequente entre actores e espectadores, a plebe romana chegava a ser a actriz principal.

O espectáculo teve, efectivamente, muita cor, luz, ritmo, canto e dança. Entre os actores, importa destacar o desempenho de Javier Ortega Jaén, que foi um Tranião cheio de carisma, astúcia e poder de improvisação, como convém a um escravo plautino que se preze.

Elenco - Actores: Fco. Javier Ortega Jaén / Esther Pumar Reyes (Tranião), Fátima Jiménez Enrique / María Serpa Mora (Grumião), Jesús Ma Gutiérrez Torres / Patricia López Ocaña (Filólaques), Elisabeth Mena Linder / Ines Higueras (Filemácio), Margarita Domínguez Sánchez / Libertad Marín 
Rueda (Escafa), Antonio Zarola Ortiz / Adrián Varo García (Calidamates), Esther Pumar Reyes / María Serpa Mora (Délfio), Eva Ma Rodríguez Cruz / Jesús María Gutiérrez Torres (Teoprópides), Fátima Jiménez Enrique (Usurário Misargírides), Marcos Collado Martín / Enrique Lainer (Simão), Rocio García Heredia (Mulher de Simão), Valentín Murillo Romero / María Serpa Mora (Fanisco), Juan Lorca Muñoz (Pinácio), María Serpa Mora / Juan Lorca / Regina Carballo Lopez / María Torres (Cupidos), Zoraida Valiente Rodríguez, Carmen Clara Ciria Roselló, María Serpa Mora, Libertad Marín Rueda, Regina Carballo López, María Reyes / Aida, Rocio Lainer, María Torres (Marinheiros e Prostitutas); Adereços - Trabalho de grupo; Vestuário - Trabalho de grupo; Director Técnico e de Luzes - Joaco Arjona Cabrera; Som - Antonio Pecho Martín. Colaboração do Coral juvenil "Juan Cárave"; Director - Enrique Iglesias.

Paulo Sérgio Ferreira

\section{PSÊUDOLO}

Parte da cena I do acto I do Psêudolo de Plauto

Encenadores: David Malta e Luís Oliveira

Tradução: Luís Oliveira

$1^{a}$ Apresentação: Calvão, Colégio Nossa Senhora da Apresentação

Data: 22. 2. 2003.

Os professores Luís Oliveira e David Malta apresentaram parte da cena I do acto I do Psêudolo de Plauto, no âmbito da Ceia à moda dos Romanos, realizada no Colégio Nossa Senhora da Apresentação, a 22. 2. 2003. (Guapidoro).

Elenco: Actores - Luís Oliveira (Psêudolo), David Malta

Paulo Sérgio Ferreira

\section{ADAPTAÇÕES DE PLAUTO}

Molière, As artimanhas de Scapin

Produção: Grupo de Teatro de Calvão

Encenação: David Malta

1. ${ }^{a}$ Apresentação: Glória do Ribatejo

Data: 14. 5. 1994 
Outras: Calvão, 22. 5. 1994; Vagos (Escola C+S Dr. João Rocha (Pai)); Santa Catarina, 18. 3. 1995; Fonte de Angeão, 1. 4. 1995; Guilhovai, 24. 6. 1995; Sôsa, 25. 11. 1995; Ponte de Vagos, 2. 12. 1995; Praia da Vagueira (?).

O Grupo de Teatro de Calvão levou à cena As artimanhas de Scapin de Molière. Esta produção, dirigida por David Malta, foi uma forma de assinalar os dez anos de existência do grupo. Foi a terceira vez que o GTC levou à cena uma peça de Molière: já antes tinha encenado $O$ Avarento e $O$ médico à força. Do repertório do grupo fazem ainda parte obras de autores como Ruzante, Miguel Torga, Sttau Monteiro e Raul Brandão.

As artimanhas de Scapin, escritas em 1671, tratam o tema dos dois velhos que se vêem ludibriados por um criado, Scapin, que é a artimanha em pessoa. Depois das mirabolantes aventuras de uma rapariga, raptada por ciganos e resgatada, com o dinheiro do burlado pai do noivo, e do reconhecimento de que ela, afinal, era filha de um rico amigo do velho, tudo acaba com a feliz união dos jovens. Após um arraial de paulada em Gerôncio, ele ainda termina a peça a desculpar Scapin de tudo quanto tinha feito.

Particularmente cómica era a cena II do acto III, em que Scapin, mediante uma pretensa caça ao homem, movida pelo irmão da esposa de Octávio e seus amigos - «todos espadachins», nas palavras do próprio Scapin -, se propunha fazer passar Gerôncio pela cidade, dentro de um saco, a fingir que se tratava de roupa suja. O criado simula um diálogo com os outros e aproveita para dar umas vergastadas no velho que, escondido dentro do saco, não devia pôr a cabeça de fora. Orlando Matias foi um Scapin cheio de energia e fez particularmente bem esta cena: queixavam-se ele, que tinha supostamente levado as pauladas, e o velho a quem elas efectivamente doíam. Francisco Dinis e Alírio Jorge foram dois velhos com algum reumatismo e muita ingenuidade. John Neto foi um Silvestre que exercitou umas quantas estocadas em palco, mas o pouco jeito de quem fingia de espadachim o não deixava brilhar mais naquela arte.

O balanço foi muito positivo e as ovações dos diferentes públicos mostraram à saciedade que a comédia clássica ou de tema clássico continua a divertir pessoas dos mais variados estratos sociais e com os mais diversos níveis de formação literária.

Elenco: Actores - Francisco Dinis (Argante), Alírio Jorge (Gerôncio), Hugo Jorge (Octávio), Sérgio Margarido (Leandro), Elisa de Jesus (Zerbineta), Sandra Almeida (Jacinta), Orlando Matias (Scapin), John Neto (Silvestre), Guida Almeida (Nerina), David Malta (Carlos); Luminotecnia - Joana e Fernando Terralheiro; Ponto e Contra-regra - Gina Sarabando; Guarda-Roupa - Paula Marques; Maquilhagem - Isabel Silva e Arelis; Cenários - António José, José Mário, João Paulo Freire. 


\section{Molière, Artimanhas de Scapin}

Produção: Centro Dramático de Évora

Encenação: Mário Barradas

$1^{\text {a }}$ Apresentação: Coimbra, Pátio da Inquisição (Espaço da Escola da Noite)

Data: 15 - 16 . 6 . 2001 .

Com um elenco de alunos finalistas do Grupo XIII da Escola de Formação Teatral do CENDREV, Mário Barradas colocou em cena as intrigas e mentiras de Scapin, personagem de Molière que encarna 0 conhecido tipo do criado matreiro e cheio de recursos, sempre ao serviço dos jovens enamorados e pronto a atacar os velhos avarentos e os pais intransigentes.

Elenco: Actores - Alexandre Guedes de Sousa, Ana Ademar, Ana Margarida Videira, Carlos Custódio, Celino Pendérlico, Cláudia Carvalho, Hugo Caroça, Maria Marrafa, Rui Ângelo, Ricardo Cruz.

José Luís Brandão 
(Página deixada propositadamente em branco) 


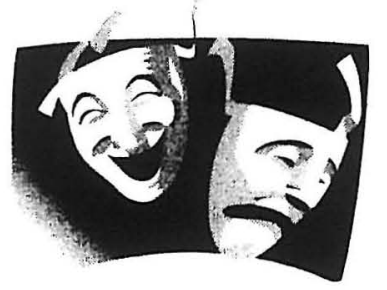

TERÊNCIO 
(Página deixada propositadamente em branco) 


\section{EUNUCO}

\section{Terêncio, Eunuco}

Produção: Teatro Calatalifa, Escola Municipal de Teatro de Villaviciosa de Odón (Madrid)

Encenação: Sáenz Almeida

Iniciativa: FESTEA - Festival de Teatro de Tema Clássico

$1^{\mathrm{a}}$ Apresentação: Viseu, Teatro Viriato

Data: 3. 5. 2002.

Um dia a mãe da cortesã Taís, que morava em Rodes, recebeu uma criança ateniense, Pânfila, que ela educou como sua filha. Ao morrer, porém, o irmão, ganancioso, vendeu-a, por obra do acaso, ao soldado Trasão, que em tempos trouxera Taís para Atenas e aí the montara casa antes de regressar à Caria. O soldado viu nessa escrava uma óptima prenda para oferecer à sua amada Taís que estimava a jovem como irmã. Vendo-se, porém, trocado por Fédria, ameaça só lhe entregar a moça se a cortesã continuasse a obsequiá-lo com os seus favores. Por isso Taís pede a Fédria, o seu novo amante, que por dois dias se ausente para o campo e não frequente a sua casa. Antes de partir, manda entregar à cortesã um eunuco que comprara. Um efebo, Quéreas, irmão de Fédria, perdidamente apaixonado pela jovem enviada de presente a Taís, veste a roupa do eunuco, a conselho do escravo Parmenão, introduz-se na casa e viola a donzela. Depois de várias e movimentadas peripécias, em que o verdadeiro eunuco é interrogado e ameaçado por Fédria, com os inerentes quiproquós, e em que o soldado quer reaver a escrava que dera de presente, após desentendimento com Taís, um cidadão ateniense, Cremes, o verdadeiro irmão de Pânfila dá a jovem em casamento a Quéreas, uma vez comprovado o reconhecimento.

Estamos perante uma comédia marcada por grande vivacidade e comicidade, o que não é vulgar nas peças de Terêncio. $\mathrm{O}$ autor soube retratar as principais personagens de forma subtil e viva, realçando as fraquezas humanas de modo divertido.

Como na antiga Roma, em que a peça obteve grande êxito na sua primeira representação e constituiu um sucesso comercial, $O$ Eunuco alegrou e contagiou os mais de 200 espectadores que encheram o Teatro Viriato em Viseu.

Elenco: Actores - Susana Verdú Martínez (Taís), Daniel Acebes Maya (Parmenão), Nacho Negreiro Achiaga (Fédria), Juan Bayona Segura (Trasão), Luis Jiménez Ramos (Cremes); Música - Víctor Carbajo; Vestuário e Figurinos - Araceli Lumbreras, Ruth Patricia Sánchez; Cenografia -Juan Bayona, Miguel Cruz; Coreografia - Karin Reitze. 
(Página deixada propositadamente em branco) 


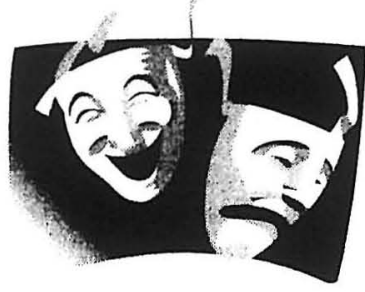

SÉNECA 
(Página deixada propositadamente em branco) 


\section{FEDRA}

Sarah Kane, $O$ Amor de Fedra

Produção: Artistas Unidos

Encenação: Jorge da Silva Melo, Pedro Marques

Tradução: Pedro Marques

$1^{a}$ Apresentação: Lisboa, Centro Cultural de Belém

Data: $10-15,17-19.3 .2004$

Outras: Lisboa (Teatro Taborda), 25. 3 - 25. 4. 2004.

Regressando ao tema do amor incestuoso, por

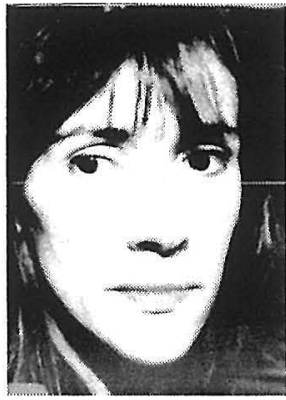

intermédio do tratamento de Séneca, a representação acentua o anacronismo resultante da caracterização de um Hipólito, fechado e recluso num quarto, entregue ao prazer da televisão e de brinquedos caros, num isolamento doentio e autista. Naturalmente aborrecido com o seu modelo de existência, Hipólito é um doente incurável. Nesta reclusão, o príncipe intenta alhear-se das desgraças do mundo que o cerca, refugiado nos seus filmes, passatempos e comida. Mas a própria lentidão de movimentos e inexpressividade de atitudes denunciam um enorme tédio e inacção. Apesar de tudo, é esse mesmo estado doentio que desperta na madrasta um amor irracional e desesperado. Sobre estes pressupostos, a representação transmite uma dinâmica de violência e de sexo, que trazem a uma história de todos os tempos um sabor vigoroso e contemporâneo.

Valorizando a concepção cénica do espectáculo, João Carneiro (Expresso, 20. 3. 2004) escreve: 'As personagens centrais e a multidão ocupam lugares diferentes de um mesmo espaço. Partilham das roupas que cobrem o chão do palácio, e que são as mesmas que cobrem as ruas ou os outros lugares. De início são actores que, a uma mesa, observam Hipólito; mais tarde serão corpos a que as luzes e as sombras permitem habitar vários lugares e várias épocas, ser uma sugestão de estatuária e de individualidades fortemente sexuadas, ser uma multidão sem deixarem de ser indivíduos'.

Elenco: Actores - Miguel Borges (Hipólito), Teresa Sobral (Fedra), Carla Galvão (Estrofe, Filha de Fedra), Paulo Moura Lopes (Médico, Padre, Teseu), João Saboga, Vítor Correia, António Filipe, Pedro Marques, Sérgio Grilo, Hugo Samora, Sérgio Gomes; Cenografia - José Manuel Reis; Figurinos - Rita Lopes Alves; Luz - Pedro Domingos; Som - Paulo Curado.

M. F. S. S. 


\section{TIESTES}

Séneca, Tiestes

Produção: Teatro da Cornucópia

Encenação: Luís Miguel Cintra

Tradução: Luís Lima Barreto com a colaboração de José Manuel Mendes e Luis Miguel Cintra

1. Apresentação: Teatro do Bairro Alto

Data: 26. 9. 2002

Outras: Lisboa (Teatro do Bairro Alto), 26 . 9 - 3. 11. 2002, de 3. a Domingo.

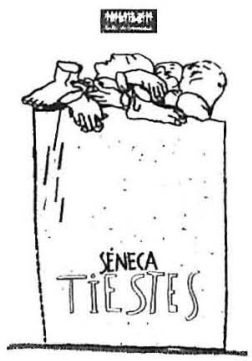

O Teatro da Cornucópia, com os apoios da RDP - antena 1 e do Ministério da Cultura/Instituto Português das Artes do Espectáculo/2002, levou à cena o Tiestes de Séneca. Luís Miguel Cintra foi o encenador desta peça que iniciou um ciclo dedicado ao tema do poder.

Tal como sucede com os restantes dramas senequianos, não se sabe se esta obra foi representada na época do autor ou mesmo se foi escrita para o palco ou apenas para a recitação. Há ainda quem sustente que esta peça foi composta num período posterior àquele em que Séneca esteve na corte de Nero.

A primeira aproximação ao texto foi feita através de um exercício de tradução, levado a cabo por Luís Lima Barreto, com a colaboração de José Manuel Mendes e de Luís Miguel Cintra. Embora admitindo o seu escasso conhecimento da língua latina e a possibilidade de terem cometido «alguma incorrecção na fidelidade ao texto original», os tradutores não deixaram de mostrar o seu respeito pela «autoridade científica da tradução» de José António Segurado e Campos, ainda que - no seu próprio dizer - tenham estado «mais atentos à prosódia e a um sintetismo indispensável à dicção dos actores» (Textos de apoio 4).

Luís Miguel Cintra reconheceu que, na preparação do espectáculo, a corapanhia se deparou com problemas de diversa ordem: além da prática retórica inerente aos dramas ter caído em desuso, os actores, marcados por uma cultura cristã com cerca de dois mil anos, sentiram ainda dificuldade em recriar monstros caracterizados por uma dimensão desumana, mitológica e irreal. Finalmente, era necessário ter em conta um público pouco familiarizado com as fábulas gregas e com a sociedade romana do séc. I d.C.

Mas não se pense que este teatro nada diz ao homem moderno: se, por um lado, questiona a lógica de consumo que rege a nossa sociedade e o modo como ela valoriza a irreflectida vertigem das imagens, constitui, por outro, uma acurada análise do homem na sua dimensão política e social. Nesta linha se entendem as considerações de actores e coro sobre o poder, a felicidade, a pobreza e a riqueza, a guerra e a paz, os deuses e o caos. E 
Cintra conclui: «Seremos capazes, com Heiner Müller, de amar a catástrofe? Este espectáculo quis-se assim. Brutal e antigo.» (Textos de apoio 4)

Da conjugação de uma monstruosidade mitológica e irreal das personagens com o carácter lento, denso e sem acção deste "teatro do pensamento", surgiu a hipótese de se fazer um espectáculo onde os corpos apenas se vislumbrassem e as vozes surgissem da penumbra do palco. Mas esta ideia acabou por não vingar porque, como o encenador observou, «a opção do espectáculo não era fazer um texto descarnado de alma por parte dos actores», mas antes «fazer passar textos que são abstractos pelas cabeças, sensibilidades e corpos de pessoas de hoje», isto é, «dar corpo à expressão dos sentimentos» ("Limites do poder," Expresso, Cartaz, 28 . 9 . 2002). O resultado foi uma conciliação entre a retórica antiga e a naturalidade da linguagem coloquial, e entre o drama um tanto estático antigo e a moderna valorização do movimento.

Os dois registos de linguagem e de representação diferenciados determinam os dois espaços em que a sala se divide, inspirados na relação palco-plateia dos teatros romanos: o dos heróis, por um lado, e, por outro, o do coro, do mensageiro e do público. Os furiosos evoluem num fosso que nos traz à memória a arena dos anfiteatros. As personagens entram por um pórtico majestático e, descaído para a direita do espectador, vê-se, nesse fosso, um monte de maçãs, símbolo do bem e do mal, sangue a escorrer das pedras de um vulcão ou das ruínas e uma espada. É um espaço simbólico, iluminado por uma ténue luz. A plateia situa-se num plano superior e a disposição dos lugares é bastante inclinada para criar uma sensação de vertigem. Entre o palco e os lugares da plateia encontra-se um muro e um corredor, por onde deambulam coro e mensageiro. Resta acrescentar que Cristina Reis concebeu esta magnífica disposição do espaço.

A José Airosa coube o papel do coro e o actor, de camisa, calças de ganga e sapatilhas e com uma serenidade e naturalidade desprovidas de quaisquer artificialismos retóricos, lá foi discorrendo sobre vários temas relacionados com a humana condição. É uma consciência no seu estado mais puro, por vezes iludida pelos dolos das personagens, que reflecte sobre a organização da sociedade humana, sobre os temas do poder, da cobiça, da riqueza e da violência, por oposição à felicidade, à "doce quietude" e à "modesta condição". De acordo com a crítica, a personagem do coro foi uma das mais conseguidas ao longo da peça. Já no dizer de João Carneiro ("O curso do sol," Expresso, Cartaz, 12.10.2002), «Milton Lopes, por exemplo, é um mensageiro que não consegue criar um registo de fluência para um texto cuja retórica exige um cuidado especial na actualização cénica, a fim de que a credibilidade se possa instalar.» $\mathrm{O}$ coro e o mensageiro dão voz a sentimentos que poderiam muito bem ser os do público.

Segundo o encenador, os actores que evoluíam no palco podiam «à vontade parecer falsos, máscaras de teatro» ("Limites do poder," Expresso, Cartaz, 28 . 9 . 2002), por oposição ao tom coloquial das intervenções do 
coro e do mensageiro. Assim se compreende a personagem da Fúria, uma diva de grotesca magnificência, que, de vestido preto comprido, serpentes à volta do corpo e luvas vermelhas de sangue, preside ao regresso do espectro de Tântalo e às atrocidades que no reencontro de Atreu e Tiestes têm lugar. Márcia Breia foi relativamente convincente mas a sua coreografia foi, por vezes, um tanto exagerada nos movimentos e nos sons que produzia. Diogo Dória foi claramente um Atreu consumido pela ideia de vingança e o modo sibilante como pronunciou grande parte do seu discurso sugeriu claramente um prolongamento dos guizos das serpentes insidiosas da Fúria. A Luís Miguel Cintra, no papel de Atreu, não há a mais pequena pecha a apontar, tal foi a intensidade com que viveu o seu discurso, sublinhando sempre, de forma notável, as frases mais importantes do texto. Impressionante foi a cena em que tentou levar à boca o cálice com o sangue dos filhos. David Almeida cumpriu no papel de secretário, inspirado nos bobos de Velásquez.

Em suma, se, como a Cornucópia demonstrou, o Tiestes de Séneca é uma peça perfeitamente representável na actualidade, não há dificuldades de natureza estrutural e ideológica da obra que nos levem a supor que ela não tenha sido escrita para o palco e nele actualizada na época do autor. Salvaguardando as possibilidades que a moderna tecnologia oferece em termos de desenho de luzes e as diferenças entre este coro e um coro senequiano original, talvez semelhante ao das peças helenísticas, a verdade é que tudo o mais que a Cornucópia fez estava ao alcance dos Romanos do séc. I d.C. Importa ainda constatar que os longos monólogos não obstam à representação da obra, mas exigem bons actores para lhes darem vida. Quanto à violência, ela está mais nas palavras e no que elas sugerem ao espectador do que naquilo que ele efectivamente vê.

Elenco: Actores - José Manuel Mendes (Sombra de Tântalo, Avô de Atreu e de Tiestes), Márcia Breia (Fúria), José Airosa (Coro), Diogo Dória (Atreu), David Almeida (Secretário), Luís Miguel Cintra (Tiestes), João Lizardo (Tântalo, Primeiro Filho de Tiestes), Ruben Lopes (Plístenes, Segundo Filho de Tiestes), João Vasco Santos (Terceiro Filho de Tiestes), Milton Lopes (Mensageiro); Assistente de Encenação - Manuel Romano; Cenário e Figurinos - Cristina Reis; Assistentes para o Cenário e Figurinos - Linda Gomes Teixeira, Luis Miguel Santos; Desenho de Luz Daniel Worm d'Assumpção; Director Técnico - Jorge Esteves; Construção e Montagem de Cenário - Abel Duarte, João Paulo Araújo com a colaboração de Alexandre Araújo; Montagem de Luzes - Elias Macovela, Rui Seabra; Operação de Luzes - Rui Seabra; Guarda-Roupa - Emília Lima. 


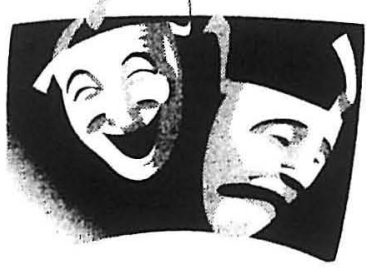

ADAPTAÇÕES DE TEMAS LATINOS 
(Página deixada propositadamente em branco) 
Rodrigo Leão, Alma Mater (obra musical)

$1^{\text {a }}$ Apresentação: Coimbra, TAGV

Data: 3. 3. 2001

Outras: Lisboa (Aula Magna), 10. 4. 2001.

Rodrigo Leão tem procurado, com vários dos seus trabalhos a solo, realizar um ideal de neoclassicismo, visível na forma como esculpe ao pormenor as suas melodias de câmara, que teimam em resistir, de certa forma, à velocidade lancinante dos tempos modernos. Esta característica pessoal, aliada a uma certa predilecção pela sonoridade da língua latina, é notória já em vários dos seus trabalhos anteriores: Ave Mundi Luminar (1993), Mysterium (1995) e Theatrum (1996).

Neste seu novo trabalho a solo (Alma Mater), a crítica tem reconhecido uma importante etapa na carreira de Rodrigo Leão, bem como a marca da inspiração em grandes nomes como Michael Nyman ou Ryuichi Sakamoto, numa oportuna fusão de classicismo e modernidade.

D. F. Leão

\section{Amor e Baco}

Produção: Teatro ao Largo

Encenação: Stephen Johnston

$1^{\text {a }}$ Apresentação: Porto, Palácio de Cristal

Data: 6 . 5 . 2001

Outras: Braga, 7 . 7 . 2001; Lisboa, 21 . 7 . 2001;

Vendas Novas, 22 . 7 . 2001; Borba, 22 . 9 . 2001 (nas

comemorações do dia europeu sem carros) e 9-10.

2001 ?.

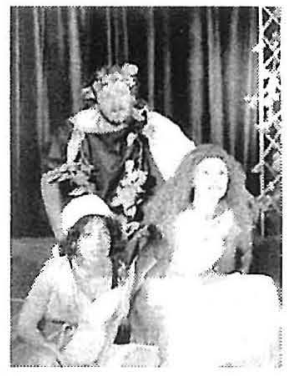

Foi esta a principal produção para o ano de 2001 do «Teatro ao Largo», grupo de Vila Nova de Mil Fontes. Teve a sua estreia no Palácio de Cristal, integrada no programa do Festival de Teatro "Fazer Festa". Segundo a informação apresentada em agendas culturais, trata-se de uma dramatização de efeitos visuais fortes, como já seria de esperar deste tema. No espectáculo se integram dança e execução musical ao vivo. São colocados em cena três contos das Metamorfoses de Ovídio. Em dois contos impera Midas, o insensato rei que pediu a Baco a faculdade (e maldição) de transformar em ouro tudo aquilo em que tocava e que, depois de curado, se tornou eremita, enfastiado do precioso metal, e se viu envolvido na arbitragem fatídica de 
uma disputa musical entre Apolo e o obsceno Pã. Um terceiro conto versa sobre o amor de Apolo por Dafne.

Além da encenação, também a música é original de Stephen Johnston.

José Luís Brandão

Heiner Müller, Anatomia Tito -Fall of Rome (um comentário de Shakespeare)

Produção: Teatro Cornucópia e Teatro Nacional D.

Maria II

Encenação: Luís Miguel Cintra

Tradução: João Barrento

$1^{\text {a }}$ Apresentação: Lisboa, Teatro do Bairro Alto

Data: 6. 11. 2003

Outras: Lisboa (Teatro do Bairro Alto), 7. 11-14. 12.

2003.

Depois de já ter encenado A missão (1984 e 1992), Mauser e a Máquina Hamlet (1998), o Teatro da Cornucópia revisita Heiner Müller, mas agora em Anatomia Tito - Fall of Rome (um comentário de Shakespeare), uma co-produção com o Teatro Nacional D. Maria II, no âmbito de um ciclo dedicado ao tema do poder. Esta peça vem, nas palavras do encenador, Luís Miguel Cintra, responder à necessidade de «concluir um ciclo com um texto contemporâneo e chamar a atenção para a busca de uma nova linguagem no teatro do nosso tempo» (apud Susana Ribeiro Martins, "H. Müller na Cornucópia," $J L, 12$. 11 . 2003). Importa recordar que deste ciclo fizeram parte, além desta peça, o Tiestes de Séneca, o Tito Andronico de Shakespeare e $A$ vida é sonho de Calderón de la Barca.

$\mathrm{O}$ texto dramático shakespeariano é manipulado pelo antigo director do Berliner Ensemble, de modo a, por um lado, mostrar a decadência do mundo ocidental e uma espécie de genealogia da luta pelo poder, e, por outro, a reflectir, nas palavras do próprio Cintra, «sobre a própria noção de teatro e de arte» (apud Susana Ribeiro Martins, "H. Müller na Cornucópia," cit.). Roma representa a América das multinacionais, gasta, decadente e invadida pelos pobres do terceiro mundo, os bárbaros Godos da peça de Shakespeare. Esta interpretação começa a ser sugerida pelo facto de parte do título aparecer em inglês, a língua do império dominante actual, que, em cenário apocalíptico, acabará por cair às mãos das pessoas do terceiro mundo. Müller introduz, no texto shakespeariano, textos poéticos curtos e, assim, fala do "sono das sociedades", de "paisagens desoladas" e de "glaciares". Se, em Shakespeare, o espectador se via confrontado com uma violência que, de 
certa forma, the causava algum bloqueio e distanciamento, Müller, de forma bem inteligente, obriga o espectador a reflectir sobre essa violência e, deste modo, a não a sentir imediatamente como estranha.

Luís Miguel Cintra foi Tito Andronico na peça de Shakespeare e em Anatomia Tito -Fall of Rome de Müller, o que the permite estabelecer as grandes diferenças entre as duas personagens e o universo mental em que se movimentam: «No sistema de valores de Shakespeare, Tito Andronico era uma personagem nobre, injustiçada, e a sua dor provocava empatia no próprio espectador. Aqui não: pedem-me uma crueldade e uma lucidez sobre a minha personagem, muito dificeis de conseguir.» (apud Susana Ribeiro Martins, "H. Müller na Cornucópia," cit.). Já como encenador, o desafio não é menor, pois, como sustenta, "a escrita de Müller é fascinante e difícil de pôr em cena, porque é uma escrita em aberto e encenar implica sempre tomar posição.» (apud Susana Ribeiro Martins, "H. Müller na Cornucópia," cit.).

O resultado não podia, na opinião de João Carneiro, ser melhor: «Luís Miguel Cintra e Cristina Reis construíram um espectáculo que recupera tudo aquilo que a Cornucópia de melhor produziu ao longo da sua existência.» ("Teatro anatómico, um repositório do que o Teatro da Cornucópia tem de melhor,” Expresso, 13 . 12 . 2003, 30). A vastidão do espaço parece sugerir o interminável curso das palavras e das ideias através dos tempos, e que as personagem e as acções desfilam nessa metáfora como se o teatro fosse o lugar natural deste discurso. Os actores, apesar das oscilações, conseguem manter uma unidade que está subjacente às diversas tonalidades e aos mais variados registos. Glicínia Quartin, enquanto coro e narradora, começa logo por proceder à identificação, através de sobreposição, do presente com os demais tempos pressupostos da peça. Rita Durão é uma Lavínia que arrasta para o presente a violência que a estigmatiza na peça de Shakespeare. Márcia Breia consegue transmitir a farsa e a paródia do original, através da mais variada gama de possibilidades expressivas. Arão encarna o lado sombrio do ser humano e Cintra alia, no seu Tito, a imagem do ditador sul-americano à complexidade de um carácter irredutível a classificações simplificadoras.

Elenco: Actores - Ângelo Torres (Arão), António Fonseca, Duarte Guimarães, Glicínia Quartin (Coro e Narradora), João Lizardo, Luís Lima Barreto, Luis Miguel Cintra (Tito Andronico), Márcia Breia, Nuno Lopes, Paulo Moura Lopes, Pedro Lacerda, Ricardo Aibéo, Rita Durão (Lavínia), Solange F.; Cenário e Figurinos - Cristina Reis; Desenho de Luz - Daniel Worm d'Assumpção. 
Astérix e Obélix: Missão Cleópatra Realização: Alain Chabat

Estreia (em Portugal): 8. 3. 2002.

Baseada num dos cadernos da genial criação de Goscinny e Uderzo, esta produção cinematográfica do realizador francês, estreada em França a 30 de Janeiro de 2002, tornou-se um

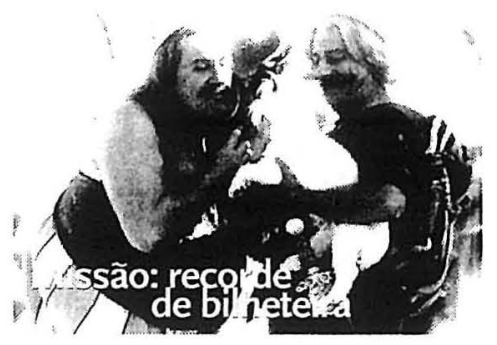
dos maiores êxitos de bilheteira.

A rodagem teve lugar em Paris, Malta e Marrocos como cenário de uma acção que se passa entre a pequena aldeia do norte da Gália, eternamente resistente à ocupação pelas hostes de César, e o Egipto da bela Cleópatra, para onde os dois inseparáveis gauleses se encaminham. O repto lançado pela orgulhosa Cleópatra ao sarcasmo do poderoso César, de reconhecer os Egípcios como o maior dos povos, caso ela lhe apresente construído em três meses o mais belo e sumptuoso palácio, jamais visto, vai pôr em verdadeiros apuros o pobre arquitecto Numerobis, o único a não ter conseguido escapar a tal encargo. A situação do arquitecto em apuros move a solidariedade dos dois gauleses, sempre prontos a não facilitar a vida aos Romanos e a César. Naturalmente que tal tarefa não pode dispensar a intervenção da poção mágica, administrada pelo druida Panoramix que, aliciado pela possibilidade de obter alguns papiros de Alexandria, acaba por ceder distribuir a poção pelos construtores.

Reunidos os três gauleses no Egipto, a equipa de construtores conhece alguns reveses criados por pérfidos antagonistas, como o sarcástico arquitecto real, Amonbofis - reveses que a poção mágica e a viva imaginação dos gauleses facilmente ultrapassa. Recheado de aventuras, que contam com o recurso a efeitos especiais, e mantendo o saboroso humor da famosa criação Goscinny-Uderzo, para que muito contribui o desempenho do versátil Depardieu-Obélix e o bom desempenho de Belluci-Cleópatra (a substituir Laeticia Casta, do filme anterior, Astérix e Obélix contra César), à data da estreia em Portugal o filme havia já sido visto por mais de 3.700 .000 espectadores.

Elenco: Actores - Christian Clavier (Astérix), Gérard Depardieu (Obélix), Jamel Debbouze (Numérobis), Monica Bellucci (Cleópatra), Claude Rich (Panoramix), Gérard Darmon (Amonbofis), Dieudonné (Caius Céplus), Édouard Baer (Otis), Alain Chabat (César). 


\section{Astérix no Criptopórtico}

Produção: Fatias de Cá

Adaptação: Carlos Carvalheiro

$1^{\text {a }}$ Apresentação: Coimbra, Museu Nacional Machado de Castro

Data: Junho a 28. 12. 2002

Outras: Coimbra (Univ. Vasco da Gama), 31. 8. 2002 - 28.12. 2002.

Carlos Carvalheiro adapta, para efeitos de encenação, enquadrada no espaço do criptopórtico romano do Museu Machado de Castro, as aventuras de Astérix e Obélix em Os Louros de César. Da discussão surgida à mesa, num banquete da aldeia gaulesa, Homeopatix, cunhado do chefe da aldeia, propõe-se preparar um excelente guisado, temperado com louro da coroa de César. Para a difícil missão de conseguir chegar à coroa, guardada no palácio de César, são destacados Astérix e Obélix, que passarão por uma série de divertidas peripécias e imprevistos com personagens romanas.

Ao efeito de cómico da movimentada acção ajuda o próprio espaço das alas e acessos do criptopórtico e a vivacidade do desempenho do grupo.

A encenação termina com um esplêndido banquete gaulês, regado com a poção mágica.

\section{C. Fialho}

\section{Ben-Hur}

Produção: Metro-Goldwyn-Mayer (EUA)

Data da Produção: 1959

Direcção Cinematográfica: William Wyler

$1^{\text {a }}$ Apresentação: Cinemas de Lisboa e RTP

Outras: Iniciativa do Colóquio Som e Imagem, IEC, 13.11.2001.

Esta adaptação ao cinema do clássico de $\mathrm{L}$. Wallace, já noticiada no vol. II, pp. 350-351, foi reexibida em Coimbra, no âmbito do colóquio Som e Imagem, organizado pelo Instituto de Estudos Clássicos da Faculdade de Letras da Universidade de Coimbra. Esta apresentação, que incluíu algumas outras reposições cinematográficas de tema clássico, foi feita no Teatro Académico Gil Vicente. 


\title{
Albert Camus, Caligula
}

Produção: Centro Dramático Galego

$1^{a}$ Apresentação: Viana do Castelo, Teatro Municipal Sá de Miranda

Data: 27. 10. 2000.

A encenação que foi apresentada em Viana do Castelo, em Outubro de 2000, resulta do trabalho de uma companhia galega.

Nuno S. Rodrigues

\author{
Albert Camus, Caligula \\ Produção: ACTA- Companhia de Teatro do Algarve \\ Encenação: Paulo Moreira \\ Tradução: Raúl de Carvalho, rev. Luís Miranda \\ $1^{\text {a }}$ Apresentação: Portimão \\ Data: 16. 11. 2001 \\ Outras: Almada (Centro Cultural Romeu Correia); \\ Faro (Teatro Lethes), 22-25, 29-30.11-1-2.12.2001; \\ Vila Real de Santo António (Centro Cultural António \\ Aleixo), 20-21.12.2001; Albufeira (Auditório \\ Municipal), 25-26.1.2002; Arcos de Valdevez (Casa \\ das Artes) 8.6.2002.
}

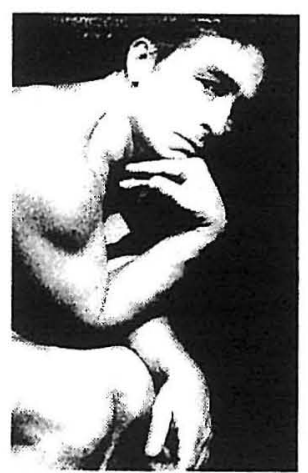

Caligula, de Albert Camus, tem sido considerado um «texto de interpretação difícil, pela complexidade da sua dramaturgia, da sua encenação e em especial do seu desempenho» (C. Porto, $J L 12$. 12 . 2001, 28). Nesta encenação desse texto, Calígula, imperador de Roma, serve de argumento para dissertar acerca da demência do poder e do poder demente. Esta adaptação reduziu o número de personagens do texto original (a dez), mas preserva a força do texto do autor argelino. $\mathrm{O}$ espectáculo encontrou uma crítica francamente positiva no momento da sua encenação, mas o grande trunfo desta produção da Companhia de Teatro do Algarve foi, sem dúvida alguma, a interpretação de Luís Vicente, como um Calígula humano e trágico que busca sentido para todas as situações em que se vê envolvido, lutando entre a necessidade de valores como a verdade, a justiça e o amor e a presença da tirania, da crueldade e do exercício desenfreado do poder. A directriz da acção é, claro, a reflexão em torno desse mesmo poder e a actualidade constante que caracteriza o tema. $\mathrm{O}$ absurdo que rodeia Calígula foi expresso pela música «melodicamente incoerente» e pelo minimalismo acentuado da plasticidade cenográfica, de que se destaca um trono em forma de mão com seis dedos (sobre o qual se senta um homem nu calçado com botas), intencionalmente acentuada pela utilização das variantes cromáticas. A actualidade do tema do poder vem, nesta produção, acompanhada do da homofilia, expressa pela relação do imperador com Cipião. A interpretação 
desta personagem, todavia, foi considerada por alguma da crítica como menos bem conseguida. De qualquer modo, o conjunto do espectáculo foi muito bem aceite, como o prova o facto de a lotação das várias apresentações ter ficado constantemente esgotada.

Elenco: Actores - Luís Vicente (Calígula), Pedro Guerreiro Ramos (Quérea), Mário Spencer (Hélicon), Glória Fernandes (Cesónia), João Naylor (Cipião), Carlos Botinhas (Senecto), Jorge Soares (Metelo), Luís Miranda (Lépido), Rui Cabrita (Múcio), Paulo Moreira (Mereia), Maria João (Lívia); Direcção de Produção - Luís Vicente; Adaptação Dramatúrgica - Paulo Moreira; Cenografia- Luís Vicente, Esmeralda Bisnoca; Desenho de LuzLuís Vicente, Noé Amorim; Música - Nélio Filipe; Assistência - Maria João; Execução Plástica e Montagem - Vitanga; Produção - Elisabete Martins; Fotografia - Jorge Soares; Secretariado - Dina Felgueiras; Direç̧ão Técnica - Noé Amorim.

Nuno S. Rodrigues

\author{
Albert Camus, Caligula \\ Produção: TEUC \\ Produtor Executivo: Gil Costa \\ Encenação: Tiago Rodrigues \\ $1^{\mathrm{a}}$ Apresentação: AAC, Teatro de Bolso \\ Data: 11-21.6. 2003.
}

Esta representação de Calígula levada a cabo pelo TEUC comemorou os 65 anos de existência do Grupo. A partir do texto de Camus, o TEUC adoptou um tipo de produção inspirado pela companhia belga Stan, com quem Tiago Rodrigues colabora; a imprevisibilidade do espectáculo e a liberdade dada ao actor dependem da inexistência de encenador. São do mesmo Tiago Rodrigues as seguintes observações expressivas do pensamento que preside a esta produção: 'As personagens são muito mais os actores e aquilo que os actores pensam das suas personagens, e os diálogos são mais conversas entre actores'. Algumas liberdades são, também na prática, desde logo patentes. Calígula é encarnado em Filipa Freitas, para além de uma personagem colectivamente designada por Patrícios dar voz a todas as vítimas de humilhação por parte do imperador. De uma forma geral as personagens adoptam um vestuário contemporâneo, caracterizado pelos ténis e por camisolas de futebol.

Elenco: Actores - Filipa Freitas (Calígula), Helder Wasterlain, Patrícia Ferreira, Alberto Ferreira, Ana Beirão, Rui Guerreiro. 


\section{Carl Orff, Carmina Burana}

Produção: Coral Lisboa Cantat

Direcção: Maestro Jorge Carvalho Alves

$1^{\text {a }}$ Apresentação: Sintra, Adega Regional de Colares e Auditório do Parque de

Palmela.

Data: 1997

Outras: Castelo Medieval de Monsaraz, 15.7.2000; Almada (Academia Almadense), 12.1.2002; Lisboa (Ruínas do Convento do Carmo), 12.7.2002, Lisboa (Pav. Atlântico), 7 . 12 . 2003.

Os Carmina Burana ( ou "canções de Beuren", uma colecção de manuscritos encontrados em 1847 no mosteiro beneditino de Benediktbeuren, Munique, e datados entre 1220 e 1250) foram apresentados por Carl Orff em 1937 (época em que a doutrina nazi estava em pleno fulgor) sob a designação de "Cantos profanos executados por cantores e coros acompanhados por instrumentos e quadros mágicos"; obteve sucesso imediato. O cancioneiro introduz-nos num ambiente de canções seculares, as cantiones profanae. Com efeito, para a realização da cantata, Orff seleccionou 24 textos e agrupou-os em três grupos: o primeiro, dedicado à Primavera, canta a renovação da natureza, a alegria e os amores jovens e inocentes; o segundo canta o ambiente de taberna, o vinho e a comida; o terceiro canta o amor e a paixão numa perspectiva mais carnal.

Em Portugal os Carmina Burana foram apresentados pela primeira vez em Lisboa, no Teatro Nacional de S. Carlos, a 25 de Março de 1954. O mesmo espectáculo foi retomado em 1958. Em 1986 a cantata foi de novo apresentada pelo Círculo Portuense de Ópera no Auditório Nacional de Carlos Alberto, no Porto.

O Coral Lisboa Cantat parece ter apresentado pela primeira vez esta obra no âmbito do $2^{\circ}$ aniversário de Sintra Património Mundial.

O espectáculo no castelo de Monsaraz, em 2000, foi uma organização da Câmara Municipal de Reguengos de Monsaraz. Além das partes corais, a cargo do Coral Lisboa Cantat e do Coro Infantil, actuaram como solistas a soprano Ana Paula Russo, o tenor Carlos Guilherme e o barítono Paulo Ferreira; como pianistas, Armando Vidal e Francisco Sasseti; como percussionistas Elisabeth Davies, Richard Buckley, Limo Correia, Abel Cardoso, Carlos Almeida e Carlos Salomé.

Em 2002 a obra foi apresentada em Almada pelo Coral Lisboa Cantat, Coro Juvenil do Conservatório Regional de Setúbal e Orquestra Sinfónica Nacional sob a direcção de Jorge Carvalho Alves. Intérpretes, segundo o site informativo, foram a soprano Ana Paula Russo, o barítono Luís Rodrigues; Elisabeth Davies na percussão e António Malão e Patrícia Gavinho ao piano.

Este Coral participou ainda na apresentação da peça em Janeiro de 2002, no Coliseu do porto, numa iniciativa da Orquestra Nacional do Porto 
em que tomaram ainda parte o Coro do Círculo Portuense de Ópera e o Coral do Instituto de Ciências Biomédicas Abel Salazar (v. notícia seguinte).

José Luís Brandão

\section{Carl Orff, Carmina Burana}

Produção: Orquestra Nacional do Porto

Direcção: Maestro Marc Tardue

$1^{a}$ Apresentação: Porto, Coliseu

Data: 25-26 . 1 . 2002.

Nesta iniciativa a Orquestra Nacional do Porto foi acompanhada pelo Coro do Círculo Portuense de Ópera, pelo Coral do Instituto de Ciências Biomédicas Abel Salazar e pelo Coral Lisboa Cantat.

O director da Orquestra do Porto, Jorge Vaz de Carvalho, salientou que foi preciso apenas uma semana de preparação para este espectáculo (v. Jornal de Notícias, 25.1.2002), uma vez que todos os participantes já conheciam a obra (v. notícia anterior).

Elenco: Solistas - Dora Rodrigues (soprano), Carlos Guilherme (tenor), Julian Frontal (barítono).

José Luís Brandão

\section{Carl Orff, Carmina Burana}

Produção: Orquestra Gulbenkian, Coro Gulbenkian, Orquestra Infantil da Academia de Música de Santa Cecília

Direcção: Maestro Michael Zilm.

$1^{\text {a }}$ Apresentação: Grande Auditório Gulbenkian

Data: $14-15$.2 . 2002

Outras: Santa Maria da Feira (Grande Auditório do Europarque), 16.2.2002.

Do elenco, destaca-se o carácter internacional e excelência do curriculum dos solistas participantes: a soprano Annette Dasch, natural de Berlim, é vencedora de três concursos internacionais: o Maria Canals, o Robert Schumann - na área do Lied - e o Concurso de Canto de Genebra; o tenor Jacek Laszczkowski, polaco, formou-se na Academia Rossini de Pesaro e tem um percurso virado para o bel canto; o barítono Erik Werner, nascido nos Estados Unidos, fez estudos um pouco por toda a Europa. 
Elenco: Solistas - Annette Dasch (soprano), Jacek Laszczkowski (tenor), Erik Werner (barítono)

José Luís Brandão

\section{Carl Orff, Carmina Burana}

Produção: Círculo Portuense de Ópera / Orquestra Nacional do Porto

$1^{\text {a }}$ Apresentação: Porto, Coliseu

Data: 27, 30, 31. 5. 2003.

M. F. S. S.

\section{Cirius, Via Sacra Profana}

Produção: Câmara Municipal de Ferreira do Zêzere

Director Artístico: Carlos Carvalheiro ("Fatias de Cá")

$1^{\text {a }}$ Apresentação: Dornes

Data: Setembro de 1999

Outras: Dornes, 17. 9. 2000; 26. 8. 2001; 25. 8. 2002.

Mais do que uma peça de teatro, Cirius: Via Sacra Profana é uma peregrinação teatral pelos quatorze cruzeiros existentes entre Paio Mendes e Dornes. Associada às tradições das romarias a Dornes, esta iniciativa verdadeiramente inovadora conta a história da Paixão de Cristo ao longo de um "palco" de quatro quilómetros.

De acordo com Carlos Carvalheiro, autor da versão utilizada (elaborada a partir dos Evangelhos de João, Lucas, Marcos e Mateus) e director artístico do espectáculo, o objectivo primeiro deste projecto seria teatralizar de uma forma não religiosa uma manifestação de cariz religioso que, na tradição católica, costuma ser feita durante a Quaresma e que, na sua opinião, não coincide, em vários aspectos, com a versão do Novo Testamento sobre o processo movido contra Jesus. Mas o desafio maior seria mesmo conseguir levar a audiência a reflectir sobre um acontecimento passado há 2000 anos e fazê-la compreender que as mortes, o sofrimento e as injustiças que daí resultaram (e ainda hoje continuam a resultar!) são uma consequência directa da intolerância que domina o mundo e que torna tão difícil mudá-lo de forma a alcançar-se o bem-estar da raça humana. Em última análise, seria esta a interrogação que Carlos Carvalheiro desejaria deixar nos espíritos dos assistentes: "De quanto mais tempo precisaremos para nos tornarmos intolerantes com a intolerância?"

Depois do êxito alcançado em 1999, Cirius: Via Sacra Profana volta a constituir, nos anos que se seguem, uma aposta forte da autarquia de Ferreira do Zêzere. Com ligeiras variantes de ano para ano, esta iniciativa de 
características ímpares contou sempre com muitas dezenas de participantes empenhados (na maioria dos casos, membros de colectividades do Concelho, mas também, alguns deles, oriundos de países estrangeiros), com meios técnicos consideráveis e com a presença de várias centenas de espectadores.

Em termos gerais, podemos dizer que o público é convidado a percorrer quatorze cruzeiros, onde se vão desenrolando breves quadros teatrais (com diferentes actores de quadro para quadro) que relatam a história da Paixão de Cristo: $1^{\circ}$ Cruzeiro - Unção (Jesus é ungido como rei, em Betânia, por Maria, irmã de Lázaro); $2^{\circ}$ Cruzeiro - Adoração (Jesus manda buscar um burro para entrar em Jerusalém, é aclamado e expulsa os vendedores do Templo); $3^{\circ}$ Cruzeiro - Última Ceia (Jesus partilha uma ceia com os apóstolos e manda Judas avisar os que o irão prender); $4^{\circ}$ Cruzeiro Agonia (Jesus pede acompanhamento no Monte das Oliveiras e incita os apóstolos a armarem-se); $5^{\circ}$ Cruzeiro - Prisão (Pedro reage violentamente contra os que vieram para prender Jesus, mas este troca a sua prisão pela liberdade dos apóstolos); $6^{\circ}$ Cruzeiro - Caifás (Jesus é presente ao tribunal judaico); $7^{\circ}$ Cruzeiro - Negação (Pedro nega conhecer Jesus; Judas devolve as trinta moedas e enforca-se); $8^{\circ}$ Cruzeiro - Pilatos (Jesus é presente ao tribuno romano); $9^{\circ}$ Cruzeiro - Suplício (Jesus é supliciado); $10^{\circ}$ Cruzeiro - Calvário (Jesus é encaminhado para o local da crucificação); $11^{\circ}$ Cruzeiro - Crucificação (Jesus é crucificado); $12^{\circ}$ Cruzeiro - Morte (Jesus é dado como morto por um centurião romano); $13^{\circ}$ Cruzeiro - Descida da cruz (Jesus é levado para o sepulcro por partidários seus); $14^{\circ}$ Cruzeiro Sepulcro (Jesus surge a Maria Madalena e a outras mulheres que vinham ao sepulcro com produtos cicatrizantes). No final do espectáculo, a assistência tem à sua espera o Bodo, que consiste na partilha de pão, carne, vinho e fruta por todos os que intervieram na iniciativa teatral. Segundo Carlos Carvalheiro, este momento "encerra em si o simbolismo da comunhão e do respeito pelo outro, onde não tem lugar a ganância, a mesquinhez e o atropelo". O dia encerra com a actuação de um grande coro, seguida de fogo de artifício.

Cláudia Cravo

Cesare Pugni, Diane et Actéon (extractos)

Produção: Ballet Opéra de Paris

Coreografia: Agrippina Vaganova

Iniciativa: Noites de Bailado

$1^{a}$ Apresentação: Sintra, Jardins do Hotel-Palácio de Seteais

Data: 25-27. 8. 1995.

Trata-se de um pas-de-deux, concebido por Galina Ulanova e Vakhtang Tchabukiani, que, em 1935, Agrippina Vaganova incluíu no $2^{\circ}$ acto 
do bailado La Esmeralda, na cena dos esponsais, em vez dos costumados cortejos com cestos de flores, inovação que G. Kremchevskaia atribuiu ao facto de o mito de Diana e de Acteón ser habitualmente apresentado nas "festas oferecidas nas casas da aristocracia russa, ponteadas de mitologia e muito ao gosto da diversão ao estilo francês".

Elenco: Bailarinos - Elisabeth Platel, Nicolas Le Riche.

Ana Paula Quintela Sottomayor

Henry Purcell, Dido e Eneias

Produção: Atelier de Ópera da Escola de Música do Conservatório Nacional Direç̧ão Musical: José Manuel Araújo

Encenação: Jorge Listopad

$1^{\text {a }}$ Apresentação: Lisboa, Palácio Nacional da Ajuda

Data: 15-16. 6. 2001

Outras: Lisboa (Teatro da Trindade), 19. 6. 2001.

Susana Hora Marques

Can Themba, $O$ Fato (Le costume)

Produção: Peter Brook

Iniciativa: Culturgest

Apresentação: Lisboa

Data: 11-12. 1. 2002.

À primeira vista, um título como $O$ Fato deixa passar absolutamente despercebida a influência clássica greco-latina que a peça contém. As suspeitas começam, no entanto, a surgir quando se constata que o nome da personagem masculina do casal protagonista é Filémon. A esposa, ao invés do sucedido no livro VIII (vv. 611-724) das Metamorfoses de Ovídio, chamase Mathilda. Mais do que uma adaptação imposta pela distância temporal que separa as duas obras, a alteração onomástica deve ser lida à luz da natureza da relação estabelecida entre ambos os textos. Can Themba prima por moldar a realidade do fervilhar de Sophiatown, uma cidade sul-africana, durante o apartheid, com o auxílio subliminar de fragmentos de um mito ovidiano, simbiose enraizada na herança mais vetusta da tragédia.

Em comum com a história de Filémon e Báucis, narrada pelo poeta latino, tem $O$ Fato a presença de um casal feliz. As fracturas face à matriz dão corpo e voz a um universo de referência bem diverso, a vida em 
Sophiatown. Retratada como 'um lugar em que o amor, o sexo e o crime conviviam com a alegria e a criatividade' (in Expresso 19 . 1 . 2002, 21), a cidade acaba por ser palco da consagração não da harmonia e dedicação de um casal até à morte, à imagem da proposta pelas Metamorfoses, mas por, numa nítida influência da tragédia, encenar a fatalidade humana do desgosto da morte. Na verdade, a infidelidade de Mathilda, descoberta, leva o marido ao caminho da vingança, cujo desfecho, inevitável, acaba por ser a morte. Cumprem-se os desígnios do género trágico, despertar no público a compaixão e o medo, conforme se pode deduzir da seguinte observação do crítico do Expresso: 'Não faltam a emoção e a piedade para nos gratificar, no fim, depois do enorme prazer que experimentámos durante todo o espectáculo'.

Sobre a encenação e o trabalho de actores foi-nos ainda possivel recolher a informação de que se tratou de 'um modelo de simplicidade que pode recompensar uma vida inteira dedicada ao teatro'.

A peça de Can Themba estreou no Théâtre de Bouffes du Nord, em Paris, no ano de 1999, e foi trazida a Lisboa pela Culturgest, nos dias 11 e 12 de Janeiro de 2002.

Carmen Soares

Flória Emilia Saúda Aurélio Agostinho Bispo de Hipona Régia

Produção: A Companhia de Teatro do Algarve (ACTA)

Encenação: Luís Vicente

$1^{a}$ Apresentação: Faro, Teatro Lethes

Datas: 27.3 .2003

Outras: em exibição até 19 de Abril; Lagos, 22.5.2003; Albufeira (Auditório Municipal), 67.6.2003; Lagos (Centro Cultural), 11.10.2003; Vila Real de Santo António (Centro Cultural António Aleixo), 17.10.2003.

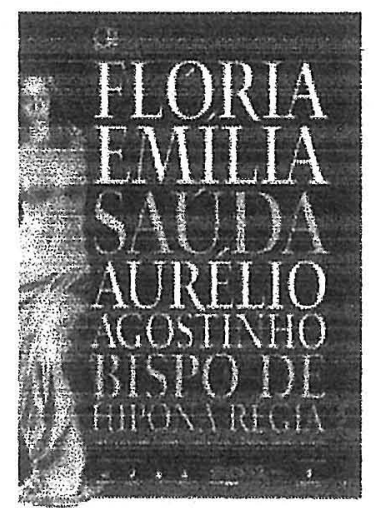

Trata-se da encenação da revolta da antiga amante de Santo Agostinho que lhe vem censurar a renúncia ao amor em consequência da sua conversão ao cristianismo. A peça é claramente inspirada pela obra de Jostein Gaarder, $A$ vida é breve: o título da representação corresponde precisamente ao começo da obra daquele autor. Jostein Gaarder compõe, na forma epistolar, um discurso da mulher despeitada, preterida por causa de valores que não compreende, incapaz de aceitar a renúncia ao mundo imposta ao clérigo, e que, a partir daí, antecipa o menosprezo com que tantas vezes se há-de encarar a mulher no seio da igreja. Além de colocar ao leitor o drama 
humano do conflito de valores e de sentimentos, esta breve obra é ainda assinalável pela riqueza da cultura clássica que envolve e transmite.

O espectáculo da ACTA, que, além de Jostein Gaarder, recorre a textos do próprio Santo Agostinho e de Teixeira de Pascoaes, resulta bastante criativo e consiste no discurso das personagens (Agostinho e Flória) e um terceiro que nos é oferecido em forma narrativa. A incidência da luz sobre a personagem feminina permite transformar o seu monólogo num manifesto contra a actual filosofia de vida de Agostinho e os votos que o privam da dimensão humana realizada no amor carnal - e logo ele que repetidamente experimentara os prazeres mundanos, que apreciara os jogos teatrais e circenses, que vivera doze anos com aquela mulher, como se de uma esposa legítima se tratasse, e da qual tivera um filho. Através da sua revolta, Flória sublinha, perante o bispo de Hipona, o que considera essencial no ser humano.

Salienta-se a riqueza humana, religiosa e literária conseguida pelo espectáculo através dos seus vários códigos: a encenação, a simplicidade do cenário, a contribuição da luz para criar o ambiente do espectáculo, a adequação da banda sonora. Notáveis as interpretaç̃̃es, de modo especial o trabalho excepcional da actriz Glória Fernandes que soube encarnar, com rigor e arte, a riqueza da personagem e do texto (v. $J L 16$. 4 . 2003).

Elenco: Actores - Glória Fernandes (Flória), Luís Vicente (Agostinho), Canto e Castro (voz off); Concepção Plástica - Luís Vicente, Noé Amorim; Execução Plástica - Tó Quintas, Vitanga; Figurinos ACTA; Luminotécnica - Noé Amorim.

José Luís Brandão

Marcos Portugal, Gli Orazi e Curiazi (Ária de Orazia)

$1^{a}$ Apresentação: Lisboa, Teatro Municipal São Luiz

Iniciativa: Teatro Nacional de São Carlos / Teatro Municipal São Luiz

Data: 1. 10. 2003.

No âmbito do programa 'Cinco Pianistas Portugueses para os Cinco Concertos de Beethoven', promovido em parceria pelo Teatro Nacional de São Carlos, pelo Teatro Municipal São Luiz, em colaboração com a Câmara Municipal de Setúbal no plano das comemorações dos 250 anos do nascimento de Luisa Todi, realizou-se um concerto onde foi executada a ária de Orazia. A execução musical coube à Orquestra Sinfónica Portuguesa do TNSC e a direcção musical ao Maestro Riccardo Frizza. Participaram ainda o pianista Artur Pizarro e a soprano Elisabete Matos.

M. F. S. S. 
Heiner Muller, O Horácio

Produção: Escola da Noite e Cena Lusófona

Encenação: Pierre Voltz

Tradução: Anabela Mendes

Iniciativa: III Estágio Internacional de Actores

$1^{a}$ Apresentação: Coimbra, Oficina Municipal do Teatro

Data: $28.11-4.12 .2003$

Outras: Aveiro (Grande Auditório do Teatro

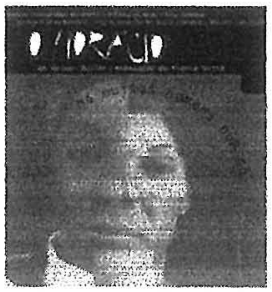
Aveirense), 20. 12. 2003.

Escrita em 1968 depois da invasão da Checoslováquia por tanques soviéticos, esta é uma versão inspirada em Tito Lívio, que narra o assassínio do Albano Curiácio pelo Romano Horácio. Porque sua irmã, a noiva do Curiácio, tomada pela dor amaldiçoa Roma, Horácio mata-a por sua vez também. Por estes actos, numa mesma figura se reúne o salvador de Roma e o assassino. 'Há muitos homens num só' constitui o drama desta figura. E também por isso o papel de Horácio é desempenhado por todos os actores. Estes, num total de 13, são provenientes de seis países lusófonos. Uma das particularidades do espectáculo é a de permitir uma interrupção para que os actores, permanentemente em cena, discutam entre si o sentido do texto.

Elenco: Actores - Amélia da Silva (Guiné-Bissau), Andrea Pozzi (Brasil - São Paulo), Carla Sequeira (Cabo Verde), Carlos Marques (Portugal), Célcio Gaspar (São Tomé e Príncipe), Érico Brás (Horácio; Brasil - Salvador), João Ricardo (Brasil - Portalegre), Margarida Dias (Portugal), Marta Gorgulho (Portugal), Ricardo Correia (Portugal), Sílvia Brito (Portugal), Sofia Lobo (Portugal), Virgílio António (Angola); Luzes - Elias Macovela; Figurinos - Ana Rosa Assunção.

M. F. S. S.

Lassus, Orlande [Roland] de [Orlando di Lasso]

Produção: Huelgas Ensemble

Direcção: Paul Van Nevel

Apresentação: Grande Auditório da Gulbenkian

Data: 6. 10. 2002.

A temporada musical da Fundação Calouste Gulbenkian 20022003 abriu com a actuação do agrupamento vocal Huelgas-Ensemble que interpretou peças de Cipriano de Rore, no primeiro dia de espectáculo, e de Roland de Lasso, no segundo. O programa dedicado a este reputado 
compositor do séc. XVI (c. 1532-1594) incluiu, além da Missa Tous les Regretz cum Sex Vocibus e Lamentações a cinco de Sexta-feira Santa, dois motetes sobre textos humanistas: Tityre, tu patulae, baseado na Bucólica I de Virgílio, e Dulces exuviae, adaptação do lamento de Dido da Eneida (IV. 651 sqq.).

Fundado no início da década de 70 por Paul Van Nevel, o grupo Huelgas-Ensemble possui um dos mais ricos repertórios de música vocal antiga, que inclui três gravações de polifonia portuguesa: "Vesper Psalms and Lamentations", de João Lourenço Rebelo (Sony Vivarte 53115, 1993), "Canções, Vilâncicos e Motetes Portugueses. Sécs. XVI-XVII" (Sony Vivarte 66288, 1994) e "Tears of Lisbon: 16th Century Arts Songs/Traditional Fado" (Sony Vivarte 62256, 1996). No domínio dos temas clássicos, salientamos o disco "Le Chant de Virgile", gravado em Dezembro de 2000, que reúne quinze peças de diversos compositores renascentistas sobre poemas de autores latinos (de Catulo, Virgílio e Horácio).

Luísa de Nazaré Ferreira

\section{The Last Days of Pompeii}

Data da Produção: 1984

Direcção Cinematográfica: Peter R. Hunt

Exibição: RTP, 1985.

Esta produção, exibida na modalidade de mini-série para televisão, é das melhores adaptações do conhecido romance de Bulwer-Lytton, apesar de ter incluído personagens estranhas ao texto original, como a da prostituta Cloe ou a do velho senador Gaio e sua mulher Fortunata. Na essência, porém, o argumento segue as linhas fundamentais do texto de Lord Lytton, mantendo-se o protagonismo das figuras da cega Nídia, de Ione e do egípcio Arbaces.

Em termos de concepção, é notável a composição cenográfica da cidade de Pompeios, bem como os efeitos especiais utilizados para a reconstituição do desastre vulcânico de 79 d.C. De igual modo, é excelente a qualidade dos figurinos, bem como a direcção artística.

Seguindo uma linha própria deste tipo de produções, o cast distribuise por uma série de estrelas britânicas e norte-americanas. Ao nível da representação, o destaque vai sem dúvida para os desempenhos de Linda Purl, Ned Beatty, Laurence Olivier, Gerry Sundquist e Siobhan McKenna.

A produção foi passada em seis episódios, num período em que a televisão portuguesa ainda valorizava as séries filmadas de inspiração histórica. 
Elenco: Actores - Nicholas Clay (Glaucus), Duncan Regehr (Lydon), Lesley-Anne Down (Chloe), Olivia Hussey (Ione), Linda Purl (Nydia), Tony Anholt (Lepidus), Ned Beatty (Diomed), Joyce Blair (Lucretia), Brian Blessed (Olinthus), Ernest Borgnine (Marcus), Peter Cellier (Calenus), Willoughby Goddard (Medon), Stephen Greif (Sporus), Malcolm Jamieson (Petrus), Sidney Kean (Escravo), Catriona MacColl (Julia), Siobhan McKenna (Fortunata), Franco Nero (Arbaces), Laurence Olivier (Gaius), Anthony Quayle (Quintus), David Robb (Sallust), Barry Stokes (Gar), Gerry Sundquist (Claudius), Benedict Taylor (Antonius), Marilu Tolo (Xenia); Argumento - Carmen Culver, baseado no romance de Edward G. Bulwer-Lytton; Música Original - Trevor Jones; Cinematografia - Jack Cardiff; Direcção Artística - John Roberts; Assistentes de Realização Ariel Levy, Ken Shane; Departamento Artístico - Frank Billington-Marks, Paul Purdy; Som- John Ireland; Duplos- Sergio Mioni, Stefano Maria Mioni; Assistentes de Câmera - David Tondeur, Adrian Trent, Massimo Zeri.

Nuno S. Rodrigues

\section{Lusitânea}

Produção: Teatro Extremo

$1^{\mathrm{a}}$ Apresentação: Almada, Teatro Extremo

Data: 27. 3-25. 4. 2004.

Esta é uma história movimentada de sentimentos fortes, que vão do amor à ambição política. O cenário é o império romano, na sua província ocidental da Lusitânia. No texto sucedem-se excertos de Aristófanes, Catulo,

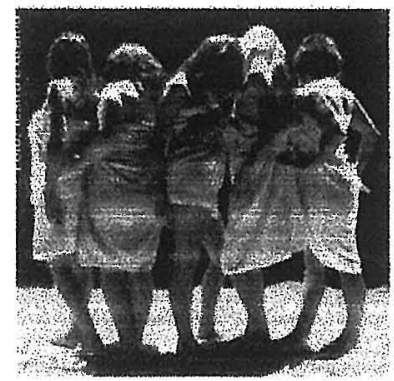
Brecht e Pessoa. Contada no feminino, a cena movimenta cinco actrizes, que vestem a pele de diversas personagens. Na busca de uma presença cultural de forte implantação, o grupo percorre em simultâneo séculos de história que é também portuguesa.

Elenco: Actores - Isabel Leitão, Antónia Terrinha, Vanessa Dinger, Isabel Mões, Catarina Santana. 


\author{
Marcial em Trajes de Cena \\ Produção: Grupo Thíasos do IEC da \\ Faculdade de Letras da U.C. \\ Encenação: Carla Braz e Carlos Jesus \\ $1^{\text {a }}$ Apresentação: Coimbra, Centro \\ Cultural D. Dinis \\ Data: 2 . 3 . 2004 \\ Outras: Coimbra (CADC), 11 . 3. 2004; \\ Sintra (Museu Arqueológico de S. Miguel \\ de Odrinhas), 3 . 5 . 2004; Louriçal, 25. \\ 6. 2004 .
}

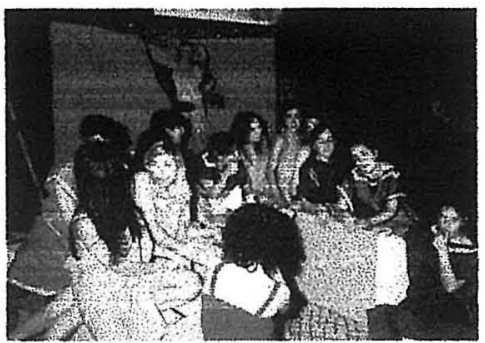

Estreou no passado dia 2 de Março, no encerramento das Jornadas Científicas Celebração de Marcial 2004, a produção Marcial em Traje de Cena, com encenação de Carla Braz e Carlos Jesus.

A peça consiste na recolha e dramatização de vários epigramas de Marcial, comemorando os 1900 anos passados sobre a sua morte, com vista à reconstituição da sua vida e obra. De uma primeira e animada cena de banquete, onde se representam os quadros sociais mais característicos da escrita do autor - como sejam os ébrios, os caçadores de heranças, os advogados, os efeminados - as personagens, todas elas inominadas, simulam alegoricamente o regresso de Marcial à sua terra na Hispânia, a bela Bílbilis. Aqui contempla ele a simplicidade da vida, tecendo invectivas ao ritmo citadino com todos os seus vícios. Mas ninguém abandona sem mais uma cidade como Roma. Nasce a saudade da agitação cosmopolita, terminando a peça com o desencanto e a morte (sugerida) da figura central.

Tudo se passa num plano simbólico. $O$ resultado que se apresenta mais não é do que um exercício de interpretação, entre outros possíveis, da vida e obra de um artista. De um artista, é certo, mas em especial de um homem que marcou o seu tempo e a posteridade por um agudo sentido crítico e satírico, por um apurado culto da vida no que tem de melhor e de pior.

Elenco: Actores - Carlos Jesus, Carla Braz, Mariana Matias, Verónica Fachada, Patrícia Martinho, Sónia Simões, Natália Alves, Isabel dos Santos, Bruno Simões, Eduardo Conceição, Ana Catarina Rodrigues, Ândrea de Oliveira, Joana Cruz, Lia Nunes; Coreografia - Carla Braz; Selecção de textos - José Luís Brandão; Consultores - Delfim Leão e José Luís Brandão; Sonoplastia - Carlos Jesus e Tiago Cabral; Luminotecnia Carlos Santos; Guarda-Roupa - Luísa Nazaré Ferreira e Inês Santos; Adereços - Carlos Santos e Inês Santos 
À mesa com os Romanos (recriação de uma cena romana)

Produção: alunos do curso de Português, Latim e Grego da Universidade de Aveiro

Encenação: alunos do curso de Português, Latim e Grego da Universidade de Aveiro

1. ${ }^{a}$ Apresentação: Aveiro, cantina do Campus de Santiago

Data: 7 . 3. 2001.

Vem comer à grande e à romana! A este sugestivo apelo, inscrito num bem elaborado folheto programático, corresponderam com hilaritas, benignitas, lepos e comitas cerca de 150 pessoas que não quiseram deixar de participar na reconstituição de uma cena romana promovida pelos alunos do curso de Português, Latim e Grego do Departamento de Línguas e Culturas da Universidade de Aveiro. Com este projecto que revivificava tradições e costumes do povo romano, os jovens classicistas pretendiam dar visibilidade ao seu curso no meio académico, concitar a adesão de outros colegas a iniciativas similares, cultivar e solidificar o espírito de coesão e de amizade entre discentes e docentes $\mathrm{e}$ - the last not the least - angariar dinheiro para a sua viagem de finalistas.

O regresso ao passado romano iniciava-se mal se transpunha a ianua da cantina universitária, transformada, nessa noite de 7 de Março de 2001, num grande triclinium decorado a rigor e com dois espaços perfeitamente delimitados: um reservado aos espectadores-comensais, o outro (o triclinium propriamente dito) destinado ao paterfamilias e seus convidados - um cônsul e um magistrado.

Ao longo de cerca de quatro horas, à luz de archotes distribuídos por colunas adequadamente enfeitadas e adaptadas à arquitectura de uma domus, os actores, trajando a preceito, foram recriando, com dignidade e acerto, a principal das refeições de uma família romana abastada. Logo após a encenação de breves quadros alusivos à vida quotidiana dos romanos, o paterfamilias deu início ao repasto que oferecia uma ementa variada, embora não tão pródiga como convinha. À gustatio (azeitonas, frutos secos $\mathrm{e}$ caccabina pequena) que ajudou a aconchegar o estômago já cansado de esperar, seguiram-se, servidos por gentis e prestimosas escravas de cetim vestidas, os fercula em número de três: almôndegas de choco com puré à moda de Cómodo, frango à Numídia com legumes, e perna de porco com mel e arroz de passas. Tudo acompanhado por vinho, mulsum ou água, apresentados em ânforas. Para a sobremesa (mensae secundae), o anfitrião havia reservado fruta e iguarias variadas: patina de pêssego, patina de desenformar doce, e rabanadas no forno com mel.

Mas uma cena romana não significava apenas variedade e abundância à mesa. Uma cena era também festa. Como tal, por entre as animadas conversas e o corrupio de pratos e de ânforas, os convivas puderam apreciar uma movimentada luta greco-romana e um prodigioso e espectacular ignis 
ludus, e deleitar-se ainda com uma sensual e bem coreografada "dança do ventre" e com uma expressiva e cadenciada recitação de adequados poemas de Alceu ("Nunc est bibendum", fr. 346 Lobel-Page), de Anacreonte ("Poldra da Trácia", fr. 72 Page) e de Catulo ("Viuamus mea Lesbia", carm. V).

Já ia alta a noite, quando terminou o espectáculo. Face ao entusiasmo e ao empenho postos na representação, ficava a certeza de que aquele tinha sido, apenas, o primeiro de outros eventos a organizar pelos jovens classicistas de Aveiro em prol da divulgação da cultura clássica.

Elenco: Actores - André Matias (Paterfamilias), Tânia Monteiro (Materfamilias), Paulo Gonçalves (Cônsul), Ricardo Oliveira (Magistrado), Inês Cardoso (Mulher do Magistrado), Paulo Gonçalves e Lara Fernandes (Guardas Pretorianos), Alexandra Castro, Ana Lúcia Silva, Ana Margarida Borges, Ana Resende, Cristina Fernandes, Daniela Oliveira, Daniela Rodrigues, Esperança Martins, Filomena Amorim, Helena Vasconcelos, Ilda Andrade, Lara Fernandes, Liana Assunção, Liliana Morais, Luciana Graça, Mariela Vieira, Mónica Pinho, Rita Silva, Sílvia Almeida, Tânia Gouveia, Vera Dias (Escravas), José Bandeira, Jorge Gonçalves (Escravos); Bailarinas- Alexandra Castro, Cristina Fernandes, Helena Vasconcelos, Liliana Morais, Vera Dias; Gladiadores- José Bandeira, Jorge Gonçalves; "Ignis ludus"- Cristina Fernandes (malabarista), Helena Vasconcelos (cuspidora de fogo); Recitação de Poemas- Luciana Graça; Quadros Vivos - Ana Resende, Jorge Gonçalves, José Bandeira, Rita Silva (figurantes), Alexandra Castro, André Matias, Liana Assunção, Tânia Monteiro (encenação); Tocadores de Jambé- Alexandra Castro, Daniela Rodrigues, José Bandeira; Guarda-Roupa- D. Fátima Santos, D. Elvira Fernandes; Som - Daniel Almeida Rosa; Apoio Técnico - Andreia Araújo, Gérson Pinho.

Carlos Morais

\section{Carlos J. Pessoa, Migalhas de um Deus Intratável \\ Produção: Teatro da Garagem \\ Encenação: Carlos J. Pessoa \\ $1^{\text {a }}$ Apresentação: Lisboa, Pequeno Auditório do CCB \\ Data: 24-28. 1. 2001.}

Migalhas de um Deus Intratável é a terceira das quatro peças que constituem $O$ Livro das Cartas do Tesouro, da autoria de Carlos J. Pessoa. Depois da abordagem dos temas da Compaixão e da Liberdade, esta produção teatral do Teatro da Garagem centra-se agora no conceito de Poder. Teodomiro, o protagonista da história, é um imperador romano imaginário, cuja vida é inspirada nas biografias de Adriano, Marco Aurélio e Júlio César. Ao longo do espectáculo, vamos assistindo à formação do carácter de 
Teodomiro, ao período da sua governação e, por fim, à fase da decadência. Depois de se desinteressar pelo poder, Teodomiro é substituído pela imperatriz, que passa a ser a personagem central da peça e que representa 0 empenhamento sério nas questões do Estado, em oposição ao egoísmo e à demanda individual do sentido para a existência, personificados pelo antigo imperador.

Em última análise, Migalhas de um Deus Intratóvel pretende salientar a dimensão política do Poder, enquanto instrumento necessário para organizar a vida colectiva, aspecto que, na perspectiva de Carlos J. Pessoa, está actualmente cada vez mais em causa. Ouçamos as suas palavras a este respeito: "Hoje em dia é difićlimo ser-se político porque não há uma ética, uma moral. $\stackrel{E}{\mathrm{E}}$ o vale tudo em nome das circunstâncias. Parece-me que a honra resulta da cultura, do sacrificio e do cansaço. É este o programa implicito na peça".

Cláudia Cravo

Heiner Müller, A morte de Séneca (sessão de leitura)

Produção: Artistas unidos

Tradução: João Barrento

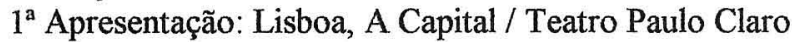

Data: 12. 4. 2000

Outras: Lisboa, A Capital / Teatro Paulo Claro, 19, 26. 4. 2000.

No sítio www.artistasunidos.pt/leituras.htm, pode ler-se: «A partir do momento em que chegámos ao espaço A Capital, quisemos criar um espaço onde se dava a ouvir regularmente, em leituras encenadas, textos que ainda não sabíamos se iríamos fazer ou textos que não iríamos encenar ou que tinham apenas a ver com aquilo que estávamos a fazer à noite.»

As sessões tinham lugar às quartas-feiras, pelas $19 \mathrm{~h} 00$.

Depois de João Meireles ter lido as Histórias do Sr. Keuner de Brecht $(8,15,23,29.3$ e 5.4.2000) e de António Simão e Gustavo Sumpta terem lido Agá o piolho de Mark O'Rowe (23-28.3.2000. Estreia: 4.5.2000 em A Capital), foi Jorge Silva Melo que leu Ajax por exemplo, $A$ morte de Séneca e o Bloco de Mommsen de Heiner Müller, nos dias 12, 19 e 26 de abril de 2002 .

Foi, de resto, a segunda vez que os Artistas Unidos fizeram uma incursão pela obra de Müller: em 1998, Jorge Silva Melo tinha encenado A queda do egoísta Johann Fatzer (Teatro Variedades). 
Horácio, O poeta e o maçador (Sátiras, 1.9)

Produção: Thíasos do IEC

Encenação: Rui Henriques

Interpretação: Rui Henriques e Ricardo Monteiro

Música e sonoplastia: Manuel Isidro Alves

$1^{a}$ Apresentação: Coimbra, Museu Machado de Castro

Data: 7. 3. 2001

Outras: França (Besançon), 14. 3. 2001; Coimbra

(Centro Cultural D. Dinis), 16. 3. 2001; Coimbra (Jardins da AAC), 18. 7. 2001; Anadia (Caves de S. Domingos), 28. 9. 2002.

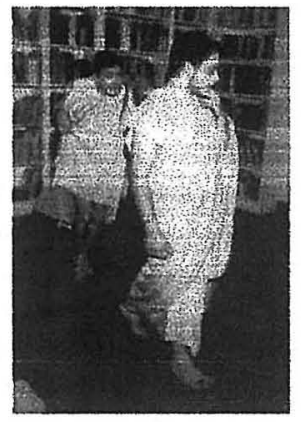

Esta dramaturgia de Horácio, adaptada para dois actores por Rui Henriques, centra-se na figura do poeta (Rui Monteiro) e num importuno maçador (Rui Henriques), que se desdobra em várias outras personalidades da Roma antiga. $\mathrm{O}$ trabalho, pensado para favorecer uma adaptação rápida a pequenos espaços, onde seja possível uma interacção próxima com os espectadores, vive, em particular, da grande capacidade que Rui Henriques tem para se metamorfosear em personalidades distintas, apoiado por uma sugestiva selecção musical.

D. F. Leão

Spartacus - O dia que nunca mais chega (música e bailado)

Produção: Companhia Abbondanza-Bertoni Coreografia: Michele Abbondanza

$1^{a}$ Apresentação: Lisboa, Pequeno Auditório do $\mathrm{CCB}$

Data: 1998.

Destinado a todo o tipo de público, este espectáculo da Companhia de dança

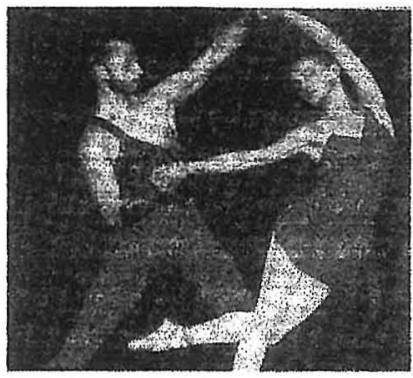
italiana Abbondanza-Bertoni foi interpretado por três bailarinos e pelos três músicos que constituem o "Rhapsodija Trio".

Spartacus - $O$ dia que nunca mais chega é um bailado de sabor circense, baseado no retrato do artista-acrobata. Três dançarinos de carrossel são atirados para uma situação de comicidade numa praça de uma vila elegante, construída em cartolina, com um céu feito de papel, num tempo sem tempo. O mundo é, portanto, um espectáculo improvisado de marionetas 
onde artistas itinerantes expressam os seus sonhos numa homenagem aos artistas de rua.

Para criar uma atmosfera do início do séc. XX, foram usadas músicas de inspiração cigana, bem como músicas tradicionais gregas, húngaras e hebraicas.

Elenco: Bailarinos - Michele Abbondanza, Antonella Bertoni, Mariatullia Pedrotti; Músicos - Maurizio Deho (violino), Cosimo Gallotta (guitarra), Giampietro Meazza (acordeão).

Cláudia Cravo

\section{Quo Vadis?}

Produção: Metro-Goldwyn-Mayer (EUA)

Data da Produção: 1952

Direcção Cinematográfica: Mervyn LeRoy

$1^{a}$ Apresentação (em Portugal): Lisboa, Cinema S. Jorge

Data: 9.10 .1952

Outras: Iniciativa do Colóquio Som e Imagem, IEC, 12. 11. 2001.

Adaptação já noticiada em volume anterior, vol. II, pp. 416-417, foi reexibida em Coimbra, no Teatro Académico Gil Vicente, no âmbito do colóquio Som e Imagem no Ensino dos Estudos Clássicos, organizado pelo Instituto de Estudos Clássicos da Universidade de Coimbra. Tendo como objectivo reflectir sobre a influência das temáticas da Antiguidade Clássica nas várias expressões audio-visuais e suas potencialidades didácticas, o cinema foi naturalmente uma das áreas desenvolvidas e, nesse sentido, a organização do colóquio apresentou, em colaboração com o Teatro Gil Vicente, uma série de filmes realizados sob o signo da História Clássica. $\mathrm{O}$ Quo Vadis? de LeRoy marcou assim presença.

Nuno S. Rodrigues

William Shakespeare, Titus Andronicus

Produção: Teatro Experimental do Porto (TEP)

Encenação, Adaptação e Cenografia: Norberto Barroca Tradução: José Miguel Silva

1. a Apresentação: Auditório Municipal de Vila Nova de Gaia

Data: 21. 11. 2002.

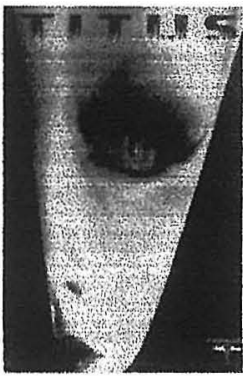


Outras: Vila Nova de Gaia (Auditório Municipal), 21. 11 - 15. 12. 2002, de $4{ }^{\mathrm{a}}$ a Domingo.

Na passagem do séc. XVI para o XVII, assiste-se, na Inglaterra de Isabel I, a um florescimento cultural que, no plano teatral, se reflectiu no aparecimento de uma elite culta e de infra-estruturas que possibilitaram o desenvolvimento do fenómeno teatral. Basta recordar, a título de exemplo, os vinte teatros que, entre 1576 e 1606, foram construídos na margem sul do Tamisa, em claro contraste com apenas um, o Hotel de Borgonha, que existia em Paris, e os dez de Veneza e um único em toda a restante Itália. Esta fase do Renascimento inglês recuperou e valorizou histórias clássicas grecolatinas em detrimento de alguns mitos continentais. Actores de nomeada da época, como James Burbage, buscavam papéis que lhes permitissem mostrar o seu virtuosismo. Nesta época, a crueldade e a barbárie dominavam os palcos ingleses. $\mathrm{O}$ público exigia-as e os tragediógrafos faziam os possíveis para satisfazerem a sua vontade.

É à luz deste contexto sociocultural e político que se entende a criação, em 1590, e a publicação, em 1594, do Titus Andronicus, a peça que muitos consideram a primeira tragédia que Shakespeare, oriundo de Stratford-upon-Avon, escreveu.

Estamos perante uma pungente reflexão sobre o poder e, mais concretamente, sobre o modo de o alcançar e de o conservar. Nesta história em particular, Shakespeare recria a época em que Godos e Romanos se envolveram em confrontos, bem como as lutas subsequentes pelo acesso ao trono romano. Espelho dos gostos da época em que foi escrita, a obra contém violações, mutilações, execuções sumárias e arbitrárias, requintadas e infames torturas e canibalismo sádico.

Foi a primeira vez que o Titus Andronicus foi levado à cena em Portugal. O espectáculo destinava-se a maiores de dezasseis anos. As guerras, muitas vezes infundadas ou insuficientemente justificadas, e a violência, veiculada pelos meios de comunicação social, indiciam a actualidade da peça.

A produção do TEP foi uma obra de fôlego, já que Norberto Barroca, além de ter adaptado o texto traduzido por José Miguel Silva, foi o encenador, o co-autor da cenografia e dos figurinos, e o actor principal.

Elenco: Actores - Norberto Barroca, Adriano Martins, Alice Vasconcelos, Aquiles Dias, Augusto Martins, David Cardoso, Fernando Moreira, João M. Mota, José Brás, Luís Gonzaga, Olga Dias, Rui Silva, Susana Sá, Vítor Nunes e os ex-alunos das Oficinas de Teatro do TEP, Alberto Vilela e Carlos Figueiredo; Cenografia e Figurinos - Mário Dias Garcia; Direç̧̃o de Actores - Clara Joana; Movimento - Ruben Marks; Desenho de Luz e Sonoplastia - Eduardo Brandão. 
Jaime Rocha, Transviriato

Produção: Trigo Limpo-Teatro ACERT (Tondela)

Encenação: José Rui Martins e Pompeu José

$1^{\text {a }}$ Apresentação: Coimbra, Pátio da Universidade

Data: 29-30. 6. 2001, 1.7. 2001

Outras: Guarda, 17-18. 6. 2001; Lamego, 27-28. 7. 2001; Silvares (Escola EB 2/3), 3-4. 8. 2001; Conimbriga, 15-19. 8. 2001; Almendra (Foz Côa), 2425. 8. 2001; Águeda, 31. 8-1. 9. 2001; Viseu, 6-8. 9. 2001; Tondela, 13-16. 9. 2001.

A lenda do mais célebre guerreiro lusitano,

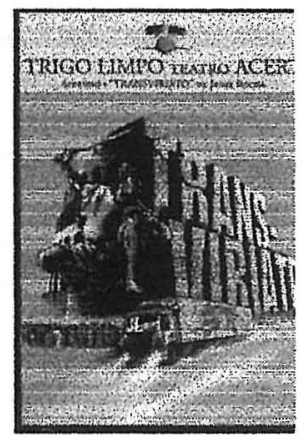
levada à cena em 1991 por O Bando (Viviriato, encenação de João Brites, vide Vol. I, p. 246) e em 1999 pelo Grupo de Teatro Fatias de Cá (Viriato, encenação de Carlos Carvalheiro, adaptação do romance $A$ Voz e os Deuses de João Aguiar, vide Vol. II, pp. 440-441), conheceu em 1991 um tratamento singular pelo Trigo Limpo-Teatro ACERT de Tondela.

Estreado em 29 de Junho, no Pátio da Universidade de Coimbra, com encenação de José Rui Martins e Pompeu José, escrito a pedido da Companhia por Jaime Rocha, Transviriato é um espectáculo de teatro de rua grandioso e, até ao momento, a maior produção do Trigo Limpo.

Aqueles que em 1990 assistiram à representação de rua de Os Covaleiros de Aristófanes (encenação de José Rui) guardam, certamente, a memória de um trabalho de grande qualidade e ousadia (vide Vol. II, pp. 151152). As expectativas em relação a este Transviriato aumentam quando avistamos a estrutura metálica na qual decorre o espectáculo, uma verdadeira arena romana, que pode acolher até 300 espectadores. No seu interior, é quase impossível não sentir uma certa estranheza perante o ambiente sombrio e cerimonial do espaço da cena. Também não nos deixa indiferentes o cartaz promocional, inspirado no do filme Ben-Hur, de William Wyler (1959): o camião Tir não é, em boa verdade, um ornamento, pois a peça foi levada a nove localidades - Coimbra, Guarda, Silvares (no âmbito da 'III Semana Cultural Terras do Xisto', que decorreu de 31.7 a 5.8.2001), Lamego, Almendra, Águeda, Viseu e Tondela - num total de cerca de 25 representações, cumprindo-se o desejo de descentralizar e promover a acessibilidade ao teatro de outros públicos. Ora, se o Pátio da Universidade de Coimbra tem, sobretudo nos últimos tempos, acolhido diversas produções teatrais, tal é quase inédito na vila de Silvares, não obstante ser uma das mais desenvolvidas do concelho do Fundão. Em cada uma dessas localidades, o Trigo Limpo promoveu actividades de formação teatral e recrutou alguns figurantes para integrarem 0 'Povo' do Transviriato. Foi com este espectáculo monumental que a Companhia de Tondela assinalou os seus 25 anos de actividade teatral. 
Jaime Rocha é jornalista e iniciou a sua carreira literária em 1970 com o livro de poesia Melânquico (Livros sem Editor). Desde então dedica-se à poesia, à ficção e ao teatro, e a qualidade da sua obra tem sido reconhecida pela crítica: $O$ Terceiro Andar, peça incluída em $O$ Construtor, venceu o Grande Prémio APE de Teatro referente a 1998, e Seis Mulheres Sob Escuta recebeu em 2000 o Prémio Eixo Atlântico de Textos Dramáticos.

Em Transviriato é constante o olhar crítico sobre o passado e o presente de Portugal. Como o título sugere, o seu autor não tem a preocupação do rigor histórico nem pretende elevar a faceta guerreira de Viriato, mas, nas suas próprias palavras, detém-se num “...Viriato que ilustrasse a resistência de um povo à procura de uma identidade e de uma terra, que simbolizasse a luta entre o passado e o presente, uma luta eterna contra as ditaduras sejam elas quais forem, venham elas vestidas da roupa mais extravagante" (p. 12).

Por conseguinte, se esta peça traz a marca de uma forte intemporalidade, como o seu autor pretendia, não faltam os reparos críticos em relação ao nosso tempo e, por isso, não se estranhe que, logo no início da representação, a personagem do 'Bobo (Viriato)' confesse que não vai contar a história, mas antes queria falar de subsídios! $\mathrm{E}$ também não é por acaso que os guardas têm ar de imigrantes de Leste e o 'Bobo (Viriato)' aconselha os espectadores a nunca, nunca deixarem de ver televisão!

Para além da riqueza do texto, respeitado quase na íntegra, uma das qualidades desta produção reside no exemplar trabalho de cenografia (a cargo de Pompeu José, Nico Nubiola e José Tavares), designadamente pela forma como souberam rentabilizar o espaço da cena, que tanto é uma arena $\left(1^{\mathrm{a}}\right.$ cena), como acolhe a tenda do general romano Vitílio ( $2^{\mathrm{a}}$ cena) e a cava de Viriato ( $3^{\mathrm{a}}$ e $5^{\mathrm{a}}$ cenas), para rapidamente se transformar no refúgio de Viriato Velho em Almofala ( $4^{\mathrm{a}}$ cena), e, mais surpreendente, dá lugar a um tribunal na última cena.

Elemento fundamental do espectáculo é a música do galego Fran Pérez, colaborador habitual do Trigo Limpo, executada ao vivo por uma animada banda. À excepção da $3^{a}$ cena, o diálogo entre Viriato e Damiana (pontualmente interrompido pelo Bobo), o espectáculo é bastante agitado. Por isso, as ligeiras alterações introduzidas, por exemplo na $4^{\mathrm{a}}$ cena, após a estreia em Coimbra, vieram beneficiar grandemente a peça, por manterem o ritmo ao qual o espectador se habitua desde o início. De salientar ainda o uso dos maquinismos, como o dragão ou a roda de tortura (o comunicado promocional do espectáculo informa que Transviriato surge na continuidade de experiências como a Máquina de Peregrinar 'Memoriar' da EXPO'98), e o adequado guarda-roupa, onde predominam as peles de cabra, numa clara alusão à vida dura do povo lusitano.

O trabalho dos actores é, de um modo geral, igualmente apreciável, mas destaca-se a figura do Bobo interpretada por Pompeu José, anfitrião, 
narrador, consciência crítica ou alter ego de Viriato, que se afirma como o fio condutor essencial de todo o espectáculo.

A peça Transviriato foi editada pelo Trigo Limpo-Teatro ACERT como bilhete do espectáculo, à semelhança do que tem vindo a acontecer nos Festivais de Teatro de Tema Clássico de Coimbra. Esta produção recebeu o apoio do Programa Operacional de Cultura (POC), das autarquias e organismos locais que têm como objectivo a promoção cultural, bem como da Universidade de Coimbra, do Parque Arqueológico do Vale do Côa, do Museu Monográfico e da Liga dos Amigos de Conimbriga, e da Associação Pinus Verde.

Elenco: Actores - Bernardo Mendonça, Carla Torres, Cláudia Andrade, Gil Rodrigues, Hugo Torres, Ilda Teixeira, Jorge Oliveira, José Rosa, José Rui Martins, Maria Miguel Almiro, Maria Simões, Marta da Silva, Miguel Torres, Nunos Ramos, Pompeu José, Ruy Malheiro e Teresa Ferreira; Músicos - Carlos Peninha, Fran Pérez, Quiné, Miguel Cardoso, Pepe Sendón e Suzo Alonso; Música Original - Fran Pérez; Cenografia - Pompeu José, Nico Nubiola e José Tavares; Adereços - Nico Nubiola, Lali Canosa e Ruy Malheiro; Figurinos - José Rosa e Ruy Malheiro; Desenho de Luz - Luís Viegas; Desenho de Som - João Paulo Martins; Desenho Gráfico - José Tavares.

\title{
Luísa de Nazaré Ferreira
}

\author{
Manuel Martínez Mediero, Verano en \\ Alexandria \\ Produção: Aula de Teatro de la UEX \\ Encenação: Asunción Mieres Royo \\ $1^{a}$ Apresentação (em Portugal): FATAL 2004- $5^{\circ}$ \\ Festival Anual de Teatro Académico de Lisboa \\ (estreia em 16. 4. 2004, em Cáceres) \\ Data: 22. 5. 2004.
}

A proposta que esta companhia de teatro académico da Universidade da Extremadura

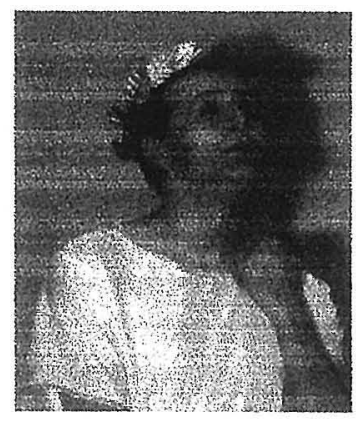
espanhola trouxe ao festival de Lisboa gira em torno da figura de Júlio César, figura maior da História de Roma. Depois da morte de Pompeio (o texto de apresentação do espectáculo deixa ler «depois de mandar degolar Pompeio», o que é contraditório com o que as fontes clássicas nos informam acerca do assunto), César está no Egipto, velho e cansado. Sendo um momento determinante no percurso político de César, é esse o momento oportuno para passar em revista a sua vida. Nesse processo, o general toma consciência de 
que todo o sucesso político e militar que obteve foi à custa de execuções e homicídios. É esse o mote que Martínez Mediero dá para esta revisitação da História da Antiguidade Clássica.

Nascido em Badajoz, em 1939, o dramaturgo Martínez Mediero dedicou-se a uma expressão simbolista, em que personagens literárias e mitológicas se debatem mais em conflitos pessoais que políticos. O Júlio César de Verano en Alexandria é exemplo disso. Deste modo, o grupo da UEX contribuiu com um dos três espectáculos de tema clássico que foram apresentados nesta edição do FATAL. Esta é uma adaptação livre da peça original.

Elenco: Actores - Fernando Sánchez Figueroa, Ruth Gallardo Ruiz, Rubén Vizcaíno Acedo, Guillaume Leterrier, Álvaro Prieto Ramos, Álvarez Díaz, Miguel Ángel Cabezas Ruiz, Estefanía Torres Sánchez, Javier Guerrero Nieto, Clotilde Durán Martínez, Ana Pilar de Ignacio Pólo, Milagros Fernández Bejarano, Eva González Abad, Ana Ortiz González, José María González Corrales; Técnico de Luzes - Óscar Latorre Caballero; Técnico de Som - José María Serrano Rodríguez; Figurino e Maquilhagem - Diana Mogollón Barbero.

Nuno S. Rodrigues

Diogo Freitas do Amaral, Viriato

Produção: Teatro da Trindade / Inatel

Direcção e Encenação: Jorge Fraga

$1^{3}$ Apresentação: Lisboa, Teatro da Trindade

Data: 25. 9-30. 11. 2003.

Diogo Freitas do Amaral regressa ao tema Viriato, para recriar, em traços gerais, a carreira pessoal e política da personagem no seu confronto entre a identidade ibérica e o poder romano. Os episódios habituais que consagram a ascensão do chefe da guerrilha, os seus amores e a teia de contestação e de traição que ditou a sua

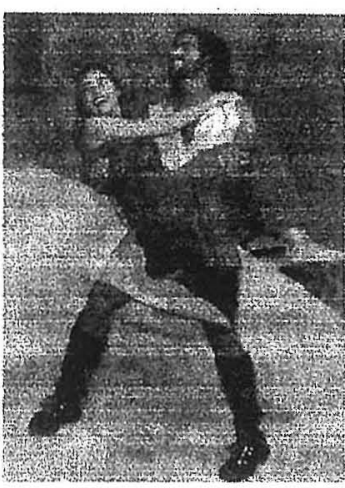
queda são também neste texto os ingredientes principais. Em comentário publicado no Expresso de 8. 10. 2003, J. C. comenta, em tom crítico, a articulação entre o teor linear do texto e a interpretação cénica adoptada por Fraga: ambos concorrendo, talvez de forma demasiado visível, 'para o tom escolar da obra'. Mesmo assim a encenação não deixou de primar pela espectacularidade. Numa tentativa de se adequar ao momento histórico do texto, o enquadramento valorizou a agrura das pedras e a rudeza das roupas; 
saliente foi também uma sequência de quadros ritualizados, como as bodas de Viriato, as feiticeiras, as cenas de combate e os funerais.

Elenco: Actores - Gonçalo Diniz (Viriato), Sandra Celas (Tangina), Ângela Pinto (Dilécia), Victor Sousa (Astolpas), Miguel Moreira, Pedro Carmo, Martinho Silva, Carlos António, Vera Paz, Jorge Loureiro, Augusto Portela, Jorge Parente, Lavínia Moreira, Tânia Lopes, André Ventura; Figurinos - Andreia Rocha; Desenho e Luz - Vítor Correia; Banda Sonora - José Prata; Música Original - António Pedro Magalhães.

M. F. S. S. 
(Página deixada propositadamente em branco) 
Colecção: ESTUDOS

Livros publicados:

1 - SCHEIDL, Ludwig - A Viena de 1900: Schnitzler, Hoffmannsthal, Musil. Kafka, Coimbra. 1985 (esgotado).

2 - RIBEIRO, António Sousa et alii - A literatura, o sujeito e a história. Cinco estudos sobre literatura alemã contemporânea, Coimbra, 1996 (esgotado).

3 - BURKERT, Walter - Mito e mitologia, Coimbra, 1986 (esgotado)

4 - GUIMARÃES, Carlos e FERREIRA, José Ribeiro - Filoctetes em Sofócles e em Heinener Müller, Coimbra, 1987 (esgotado).

5 - FERREIRA, José Ribeiro - Aspectos da democracia grega, Coimbra, 1988 (esgotado).

6 - ROQUE, João Lourenço - A população da freguesia da Sé de Coimbra 1820-1849, Coimbra, 1988.

7 - FERREIRA, José Ribeiro - Da Atenas do sec. VII a.C. às reformas de Sólon, Coimbra, 1988.

8 - SCHEIDL, Ludwig - A poesia politica alemã no periodo da revolução de Março de 1848, Coimbra, 1989.

9 - ANACLETO, Regina - $O$ artista conimbricense Miguel Costa (1859-1914), Coimbra, 1989.

10 - CRAVIDÃO, Fernanda Delgado - Residência secundária e espaço rural. Duas aldeias na serra da Lousã, Casal Novo e Talasnal, Coimbra, 1989.

11 - SOUSA, Maria Armanda Almeida e, VENTURA, Zélia de Sampaio - Damião Peres. Bibliografia analítica (1889-1976), Coimbra, 1989.

12 - JORDÃO, Francisco Vieira - Mistica e filosofía. O itinerário de Teresa de Ávila, Coimbra, 1990.

13 - FERREIRA, José Ribeiro - Participação $e$ poder na democracia Grega, Coimbra, 1990.

14 - SILVA, Maria de Fátima Sousa e OLIVEIRA, Francisco de - Teatro de Aristófanes, Coimbra, 1991.

15 - CATROGA, Fernando - O republicanismo em Portugal. Da formação ao 5 de Outubro de 1910, Coimbra, 1992.

16 - TORGAL, Luis Reis et alii - Ideologia, Cultura $e$ mentalidade no Estado Novo - Ensaios sobre a Universidade de Coimbra, Coimbra, 1992.

17 - SEABRA, Jorge et alii - O CADC de Coimbra, a democracia cristã $e$ os inícios do Estado Novo (1905-1934), Coimbra, 1993.

18 - ANACLETO, Marta Teixeira - Aspectos da recepção de "Los siete libros de la Diana" em França, Coimbra, 1994.

19 - MARNOTO, Rita - A Arcádia de Sannazaro e o Bucolismo, Coimbra, 1995.

20 - PONTES, J. M. da Cruz - O Pintor António Carneiro no Património da Universidade de Coimbra, Coimbra, 1997.

21 - SANTOS, João Marinho dos - Estudos sobre os Descobrimentos e a Expansão Portuguesa, Coimbra, 1998.

22 - LEÃO, Delfim Ferreira - As ironias da fortuna. Sátira e moralidade no Satyricon de Petrónio, Coimbra, 1998.

(23) - SILVA, Maria de Fátima Sousa e (coord.) Representações de teatro clíssico no Portugal contemporâneo, Lisboa, 1998.

24 - MARQUES, Maria Alegria Fermandes - Estudos sobre a ordem de Cister em Portugal, Coimbra, 1998.
25 - SCHEIDL, Ludwig - Mitos e figuras clássicas no teatro alemão - do século XVIII à actualidade, Lisboa, 1998.

(26)- BRANDÃO, José Luís Lopes - Da Quod Amen. Amor e amargor na poesia de Marcial, Lisboa, 1998.

27 - CARDOSO, João Nuno Paixão Corrêa - Sóciolinguística rural - a freguesia de Almalaguês, Lisboa, 1998.

28 - SOARES, Cármen Isabel Leal - $O$ discurso do extracénico - Quadros de Guerra em Euripedes, Lisboa, 1990.

29 - MONTEIRO, João Gouveia Os castelos portugueses dos finais da Idade Média. Presença, perfil, conservação, vigilância e comando, Lisboa, 1999.

30 - FERNANDES, João Luís Jesus - $O$ homem, 0 espaço e o tempo no maciço calcário estremenhoO olhar de um geógrafo, Lisboa, 1999.

31 - SEABRA, Jorge, AMARO, António Rafael, NUNES, João Paulo Avelãs - O CADC de Coimbra, a democracia cristã $e$ os inicios do Estado Novo (1905-1934), Lisboa, 2000.

32 - FERrEIRA, Paulo Sérgio Margarido - Os elementos paródicos no Satyricon de Petrónio e o seu significado, Lisboa, 2000.

33 - URBANO, Carlota Miranda - A Oração da Sapiência do P.e Francisco Machado SJ (Coimbra -1629). Estudo. Tradução. Comentário, Lisboa, 2001.

34 - DIAS, Paula Cristina Barata - Regula Monástica Communis ou Exhortatio ad Monachos? (Sec. VII, Explicit). Problemática. Tradução. Comentário, Lisboa, 2001.

35 - SILVA, Maria de Fátima Sousa e (coord.) Representações de teatro clássico no Portugal contemporâneo, Vol. II, Lisboa, 2001.

36 - MARNOTO, Rita - A Vita Nova de Dante Alighieri. Deus, o Amor e a Palavra, Lisboa, 2001.

37 - COELHO, Maria Helena da Cruz, SANTOS, Maria José Azevedo, GOMES, Saúl António, MORUJÃO, Maria do Rosário - Estudos de diplomática portuguesa, Lisboa, 2001.

38 - ENCARNAÇÃO, José d'(coord.) - As Oficinas da História, Lisboa, 2002.

39 - CARVALHO, Mário Santiago de - O Problema da Habitação - Estudos de (História da) Filosofia, Lisboa, 2002.

40- GONÇALVES, Carla Susana Vieira - Invectiva na Tragédia de Séneca, Lisboa, 2003.

41 - ENCARNAÇ̃̃O, José d'(coord.) - A História Tal Qual Se Faz, Lisboa, 2004.

42 - AMARAL, Patrícia - Do Paradigma ao Modelo, Lisboa, 2004.

43 - RIBEIRO, Maria Aparecida e VASCONCELLOS, Eliane - Drummond $e$ os Portugueses/Drummon(d)tezuma: correspondência entre Carlos Drummond de Andrade e Joaquim Montezuma de Carvalho, Coimbra, 2004.

44 - LOURENÇO, Luciano - Riscos Naturais $e$ Protecção do Ambiente, Coimbra, 2004.

45 - SCHEIDL, Ludwig - Estudos de Literatura Alemã e Portuguesa, Coimbra, 2004.

46 - LOURENCCO, Luciano - Risco Meteorológico de Incêndio Florestal, Coimbra, 2004.

47 - ARAUJO, Yann Loïc - Passos Manuel - Morte e Memoria, Coimbra, 2004.

48 - LOURENÇO, Luciano - Risco Dendrocaustológico em Mapas, Coimbra, 2004. 
49 - RIBEIRO, Maria Aparecida (coord.) Drummond em Coimbra, Coimbra, 2004.

50 - LOURENÇO, Luciano - Manifestações do Risco Dendrocaustológico, Coimbra, 2004.

51 - VAQUINHAS, Irene (coord.) - Entre "garçonnes" e fadas do lar. Estudos sobre as mulheres na sociedade portuguesa do século $X X$, Coimbra, 2004.

52 - LOURENÇO, Luciano - Risco de Erosão após Incêndios Florestais, Coimbra, 2004.

53 - MARQUES, Susana -Dois Epitalâmios de Manuel da Costa (século XVT). Introdução. Tradução. Notas e Comentários, Coimbra, 2004.

54 - FERREIRA, José Ribeiro - Labirintos do Mito, Coimbra, 2004. 
(Página deixada propositadamente em branco) 
Em resposta ao desafio lançado pelo Centro do Drama Antigo e pelo Instituto de Estudos Teatrais da Universidade de Atenas, surge neste momento - III volume de inventário das representações de teatro de tema clássico grego e latino, realizadas nos primeiros anos do séc. XXI da vida portuguesa. Deste levantamento sobressaem já, antes de mais, a amplitude do fenómeno entre nós, como as tendências particulares do gosto português. O mesmo objectivo de sempre se torna também manifesto, no dizer de Maria Helena da Rocha Pereira: "Para lá da admiração dos modelos antigos, cuja beleza nunca se extingue, está o apelo sempre renovado por situações-limite em que o homem de todos os tempos se reconhece e a si mesmo se examina".
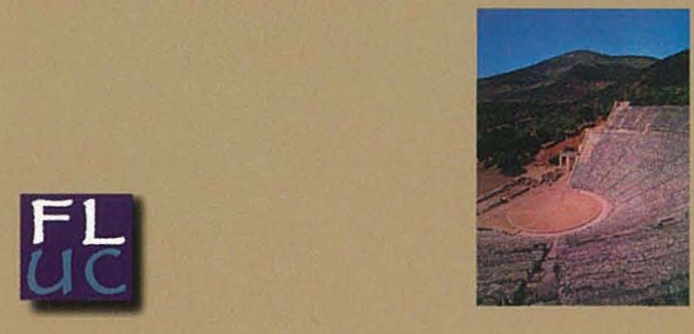